\title{
A POLITIKAI VEZETÉS HÁROM ARCA \\ A politikai vezetés értelmezési lehetőségei és gyakorlatai a demokráciában
}

\section{DOKTORI ÉRTEKEZÉS}

Témavezetők: Balázs Zoltán CSc; Körösényi András DSc

Metz Rudolf Tamás 

Metz Rudolf Tamás

A politikai vezetés három arca A politikai vezetés értelmezési lehetőségei és gyakorlatai a demokráciában 
Budapesti Corvinus Egyetem Politikatudományi Intézet

Témavezetők: Balázs Zoltán CSc; Körösényi András DSc

(C) Metz Rudolf Tamás 
Budapesti Corvinus Egyetem

Politikatudományi Doktori Iskola

\section{A politikai vezetés három arca \\ A politikai vezetés értelmezési lehetőségei és gyakorlatai a demokráciában}

Doktori értekezés

Metz Rudolf Tamás 



\section{TARTALOMJEGYZÉK}

KÖSZÖNETNYÍLVÁNÍTÁS

1. BEVEZETÉS: A KUTATÁS PROBLÉMÁJA ÉS KERETE ..............................................12

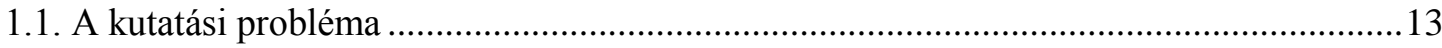

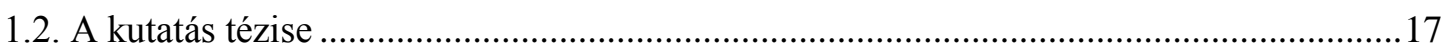

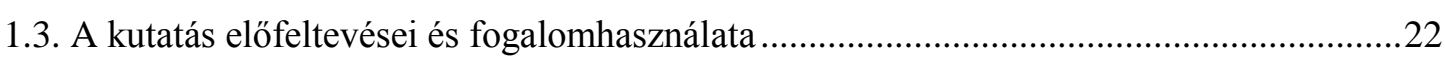

1.3.1. Első előfeltevés: a fogalom denotációja .................................................................... 23

1.3.2. Második előfeltevés: a fogalom határai .................................................................. 26

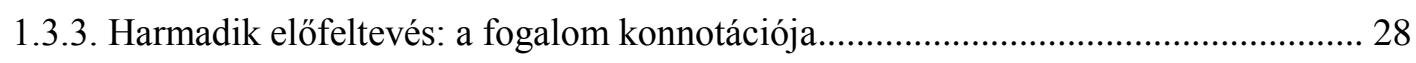

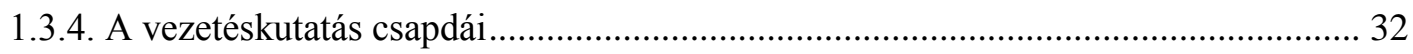

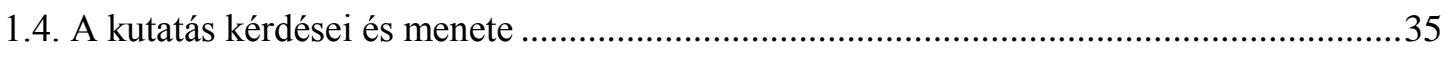

1.4.1. A demokratikus vezetés elméleti konstrukciójának vizsgálata ................................ 38

1.4.2. A demokratikus vezetés gyakorlati konstrukciójának vizsgálata.............................. 42

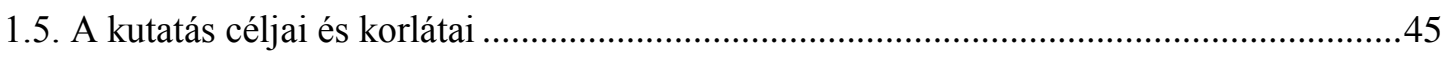

\section{ELSŐ RÉSZ:}

A DEMOKRATIKUS VEZETÉS ELMÉLETI KONSTRUKCIÓI .................................47

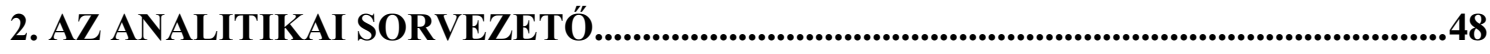

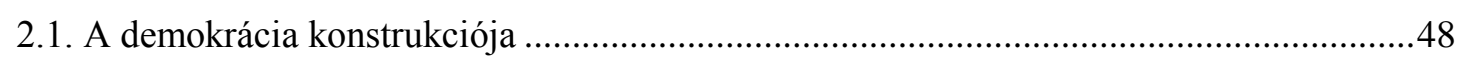

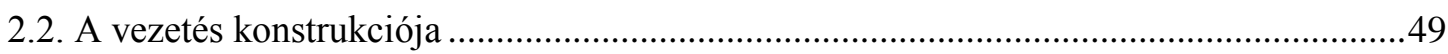

3. VEZETÉS A DELIBERATÍV-RÉSZVÉTELI DEMOKRÁCIÁBAN................................54

3.1. A deliberatív-részvételi demokrácia alappremisszái .......................................................56

3.2. A deliberatív-részvételi demokrácia implicit vezetéselmélete...........................................62

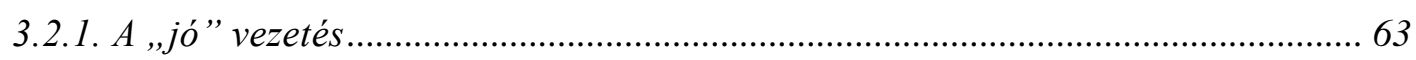

3.2.2. A , helyes" kapcsolat a vezetök és a követök között........................................... 70

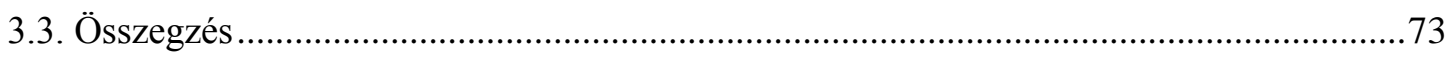

4. VEZETÉS AZ AGGREGATÍV-RÉSZVÉTELI DEMOKRÁCIÁBAN.............................75

4.1. Az aggregatív-pluralista demokrácia alappremisszái.......................................................77

4.2. Az aggregatív-pluralista demokrácia implicit vezetéselmélete.......................................83

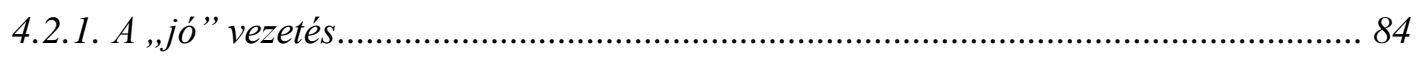

4.2.2. A , helyes" kapcsolat a vezetök és a követök között........................................... 92

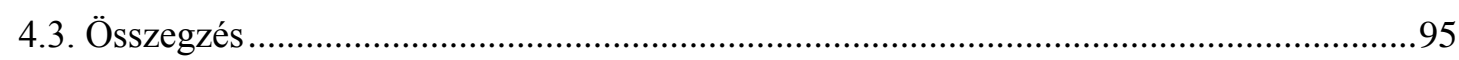

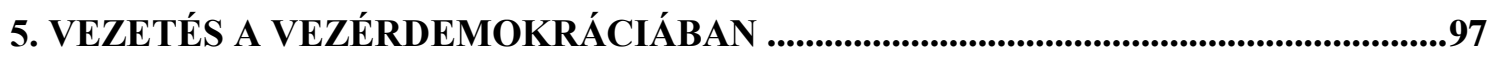

5.1. A vezérdemokrácia alappremisszái ..............................................................................98

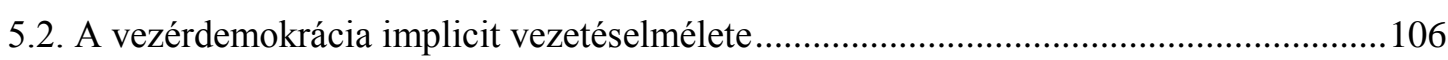

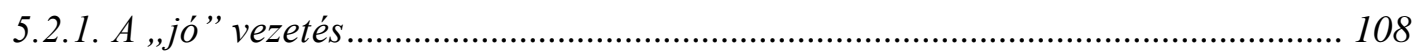

5.2.2. A , helyes" kapcsolat a vezetök és a követök között........................................ 115

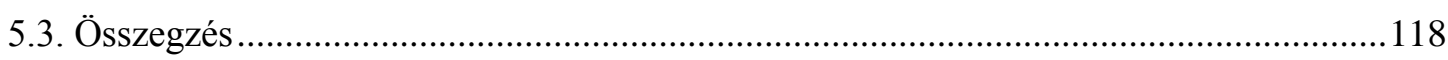

6. ÖSSZEGZŐ GONDOLATOK: A DEMOKRATIKUS VEZETÉS TIPOLÓGIÁJA ...120 
MÁSODIK RÉSZ:

A DEMOKRATIKUS VEZETÉS GYAKORLATI KONSTRUKCIÓI............................ 120

7. AZ EMPIRIKUS ELEMZÉS SZEMPONTRENDSZERE ÉS MENETE ...................... 128

8. „MUTTER ANGELA” ÉS A „KONZERVATÍV FELFORGATÓ” Angela Merkel és Orbán Viktor vezetése a menekült- /migrációs válság alatt ............. 135

8.1. Az eset kontextusa: a válság és a vezetők háttere...................................................... 136

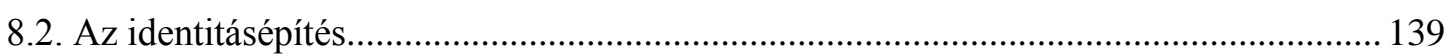

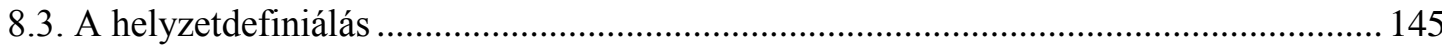

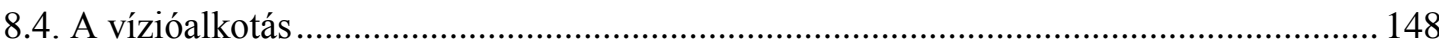

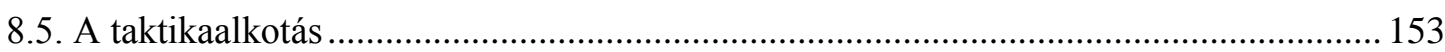

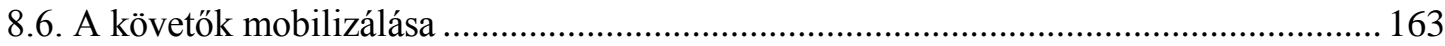

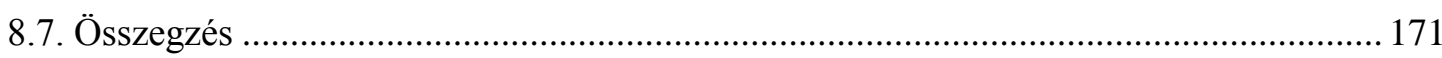

9. AZ „IGAZÁN NEHÉZ NŐ” ÉS A „LELKES AMATŐR”

Theresa May és Jeremy Corbyn vezetése a két Brexit választás között ......................... 176

9.1. Az eset kontextusa: a válság és a vezetők háttere......................................................... 176

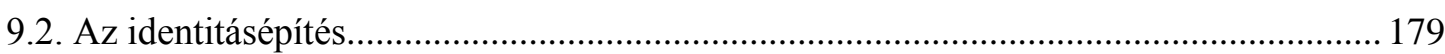

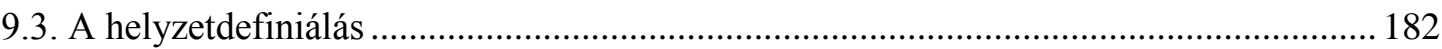

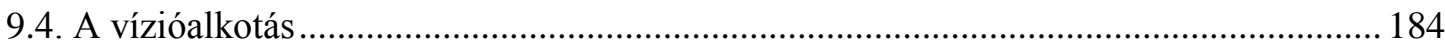

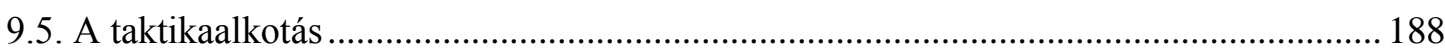

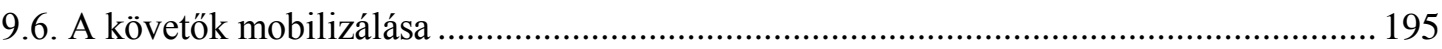

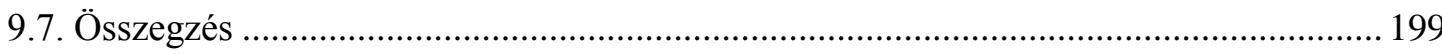

10. ÖSSZEFOGLALÁS ÉS KÖVETKEZTETÉSEK .......................................................... 204

10.1. A politikai vezetés és a demokrácia fogalmi és gyakorlati kapcsolódása ..................... 205

10.2. A demokratikus vezetés típusai az esettanulmányok fényében ..................................... 206

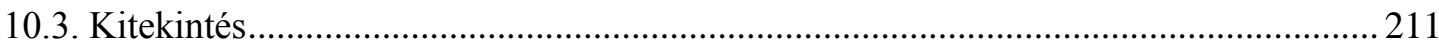

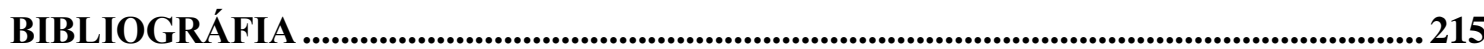

A SZERZŐ TÉMÁBAN SZÜLETETT PUBLIKÁCIÓI............................................................. 237 


\section{TÁBLÁZATJEGYZÉK}

1. táblázat: A demokrácia három értelmezése

2. táblázat: A vezetés három lehetséges értelmezése a demokráciában

(a demokratikus vezetés tipológiája)

3. táblázat: Az empirikus elemzés síkjai és kapcsolódásuk a vezetéstípusok szempontjaihoz .. 130

4. táblázat: Az empirikus elemzés fókuszai a jelentésalkotó tevékenységek fényében .............. 133

5. táblázat: Merkel vezetésének idővonala a migrációs válság során 2015. január és 2016. szeptember között 156

6. táblázat: Orbán vezetésének idővonala a migrációs válság során 2015. január és 2016.

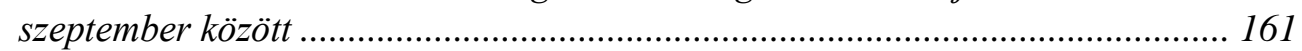

7. táblázat: Angela Merkel és Orbán Viktor vezetéskonstrukciója ….................................... 172

8. táblázat: Theresa May és Jeremy Corbyn vezetésének idővonala a két Brexit választás között. ........................................................................ 189

9. táblázat: Theresa May és Jeremy Corbyn vezetéskonstrukciója.......................................... 200

\section{ÁBRAJEGYZÉK}

1. ábra: Az interakcionista paradigma fényében a vezetés fogalma........................................... 25

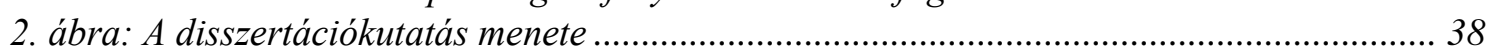

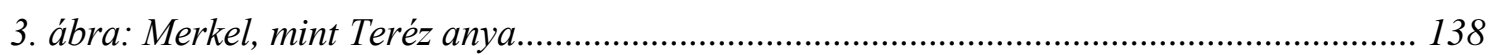

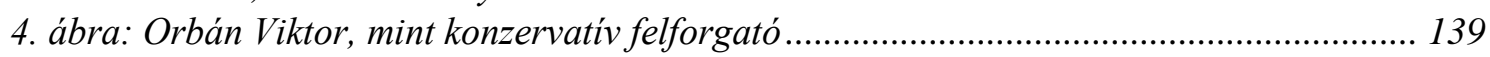

5. ábra: A releváns beszédek aránya 2015. január és 2016. szeptember között...................... 164

6. ábra: Angela Merkel elfogadottsági indexének alakulása 2015. január és 2016. szeptember között............................................................ 166

7. ábra: A CDU/CSU támogatottsága 2015. január és 2016. szeptember között a pártot választani tudó biztos szavazók körében .............................................................. 167

8. ábra: Angela Merkel és Orbán Viktor vezetéskonstrukciói ............................................... 175

9. ábra: A 2017-es választások tétjét leiró Konzervatív kampányanyag ................................ 178

10. ábra: A releváns beszédek aránya 2016. július és 2017. május között .............................. 195

11. ábra: A pártok támogatottsága 2016. július és 2017. május között a pártot választani tudó biztos szavazók körében............................................................................... 196

12. ábra: A vezetök alkalmasságának megitélése 2016. július és 2017. május között.............. 197

13. ábra: Theresa May elfogadottsági indexének alakulása 2016. július és 2017. május között.

14. ábra: Jeremy Corbyn elfogadottsági indexének alakulása

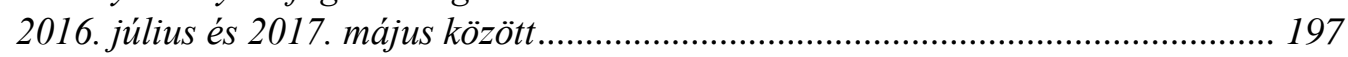

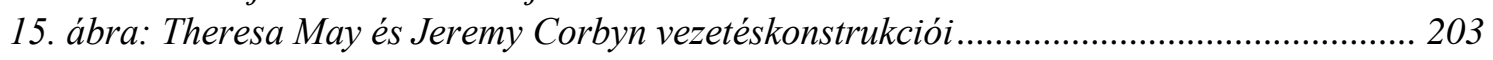

A disszertációban szereplö összes táblázat és ábra (a forrásmegjelöléssel ellátott képek kivételével) a szerző saját munkája. 
„Mi legyen hát erőfeszítéseink tárgya? Íme csak ez: igazságos gondolkodásmód, közhasznú tevékenység, állandó igazmondás és olyan lelki alkat, mely derüsen fogad mindent, ami éri hiszen, szükségszerü, természetes, és velünk egy azon kútfőből és forrásból fakad." Marcus Aurelius (1983, p. 48)

„,[Akárki is legyél]

Szolgálni fogsz valakit

Lehet, hogy az ördögöt, lehet, hogy az Urat

De szolgálni fogsz valakit"

Bob Dylan („Gotta Serve Somebody”, 1979)

„Nézz a szemembe, mond mit látsz?

A személyi kultuszt

Ismerem a haragod, ismerem az álmaid,

Voltam már minden, ami csak lenni akartál"

Living Colour („Cult Of Personality”, 1988) 


\section{KÖSZÖNETNYÍLVÁNÍTÁS}

Az emberi alkotótevékenység, legyen is szó akár müvészetről, tudományról vagy politikáról, sohasem lehet minden külső hatástól elszigetelt. Persze az alkotó, szembesülve a cselekvés szükségességével és a munka terhével úgy érezheti, hogy egyedül kell megküzdenie a felfedezéssel és az alkotással járó kihívásokkal, bizonytalanságokkal, s persze saját magával. A disszertációírás egyik sajátossága, hogy megköveteli sztoikus módjára az állandó tanulást, fejlődést és az erényes önfejlesztést. Mindazonáltal az ember talán a „kész” müvet a kezében tartva eszmél rá arra, hogy mennyi mindent köszönhet azoknak, akik közvetve vagy közvetlenül segítették és bátorították munkájában. A magányos „hős” és a sajátos együttmüködés romantikája tehát valahogy egyszerre hatja át a disszertációírást, s teszi ezzel hasonlatossá a vezetéshez. Ezért Marcus Aurelius (1983) elmélkedéseit követve, magam is úgy kezdeném e munkámat, hogy köszönetet mondok azoknak, akiknek e hosszú évek alatt leköteleztem magam.

Balázs Zoltánnak és Körösényi Andrásnak köszönhetem, hogy ez a munka minden hiányosságával, de elkészülhetett. Balázs Zoltánnal még a Pázmány Péter Katolikus Egyetemen találkoztam, ahol megszerettette velem a politikatudományt és a politikáról való szisztematikus és kritikai gondolkodást. A mai napig tisztán emlékszem arra az általa tartott szaktájékoztatóra, amelyet követően úgy éreztem, hogy megtaláltam hivatásomat. Így szerencsésnek mondhatom magam, hogy végig elkísért ezen az úton, hiszen az ő felügyelete mellett készíthettem el az alapszakos és mesterszakos szakdolgozatomat. Hozzá hasonlóképp Körösényi András is meghatározó hatással volt rám, hisz az ő iránymutatására és támogatására választottam a tudományos pályát. A számos publikációt eredményező közös kutatás során nem csak lehetőségem volt elsajátítani a tudományos kutatáshoz szükséges alapkompetenciákat, de úgy érzem emberileg is nagyban fejlődhettem. Témaválasztásomat tekintve amíg Balázs Zoltán hatalom- és értékelméletekkel, addig Körösényi András a vezetés és demokrácia kérdéseivel kapcsolatos munkái tettek rám igazán nagy hatást. Szakmai lényeglátásuk, igényességük, alaposságuk és alázatosságuk mindvégig példaként szolgáltak számomra. Összességében a disszertációírás során nagy segítség volt minőségi visszajelzéseik és szakmai és személyes támogatásuk. 
Sokat köszönhetek intézményeimnek, a Budapesti Corvinus Egyetemnek (BCE) és az MTA Társadalomtudományi Kutatóközpont Politikatudományi Intézetének (MTA TK PTI), hogy megadták azt az elengedhetetlen hátteret, amely nélkül ez a kutatás nem jöhetett volna létre. Nagyra értékelem azt a BCE Politikatudományi Intézete által megteremtett lehetőséget, hogy a kutatásaim eredményeit a „Politikai vezetők és vezetés" címü mesterszakos kurzuson átadhattam az érdeklődő hallgatóknak. Mindemellett köszönöm az Intézet és a Doktori Iskola támogatását, hogy megvalósíthattam egy másik nagy álmomat is: egy hazai politikatudományi doktorandusz konferenciát. Ugyancsak meghatározó volt számomra, hogy Körösényi András meghívott az MTA TK PTI „Politikai vezetés” kutatócsoportjába, ahol tevékeny részese lehettem számos közös kutatásnak és amelynek köszönhetően beilleszkedhettem a hazai és nemzetközi kutatói életbe.

Az évek során nagyon sok segítséget kaptam a munkatársaimtól, a Doktori Iskola hallgatóitól és tanáraitól, valamint a kutatócsoport gyakornokaitól. Különösen hálás vagyok kollégámnak, Illés Gábornak a szakmai segítségért, az angol nyelvü korrektúráért és a hosszú, de fáradhatatlan együttgondolkodásért. Mellette meg kell említenem Boda Zsoltot, Pócza Kálmánt, Soós Gábort, Dobos Gábort és Szántó Andrást, akik találó és őszinte kritikáikkal és iránymutatásukkal segítették a munkámat. Külön köszönöm nekik, hogy végigolvasták a disszertációm korábbi változatának kéziratát. Gyakornokaink közülük ki kell emelnem Hamrák Bencét, Árpási Botondot, Szedlacsek Esztert és László Lorent, akik előkészítő munkájukkal segítették a kutatásomat.

Külön köszönettel tartozom a disszertációtervezetem opponenseinek, Csizmadia Ervinnek és Gyulai Attilának, akik alapos és konstruktív bírálataikkal segítették a disszertációm újbóli átgondolását és tökéletesítését.

Végezetül, köszönöm a nagyszüleimnek, szüleimnek, húgomnak, és legjobb barátomnak Kiss Istvánnak feltétlen támogatásukat és türelmüket; és külön köszönöm a páromnak, Ruszkai Szilviának, hogy a doktori kutatás legnehezebb időszakában végig mellettem állt, motivált és biztatott, sőt még a német nyelvü források kapcsán és a korrektúrában is a segítségemre volt. Ugyancsak hálás vagyok Kelticska Attilának a magyar korrektúraolvasásban nyújtott segítségéért. Szeretném disszertációmat nekik ajánlani. Továbbá munkámmal két dédapám, vitéz lovag spondalungai Metz Rudolf (Rezső) és Vincze Ottó, Erkel Ferenc-díjas zeneszerző és karmester, emlékének 
szeretnék áldozni, akik életükben rámutattak arra, hogy a vezetés az élet minden területén ott lehet.

Mindezen túlmenően természetesen a disszertációmban minden fennmaradó hiba vagy hiányosság kizárólag az én felelősségem. 


\section{1. \\ BEVEZETÉS: A KUTATÁS PROBLÉMÁJA ÉS \\ KERETE}

Talán nem túlzás azt állítani, hogy a demokrácia és a vezetés között érzékelhető elméleti és gyakorlati feszültség a politikatudomány - pontosabban a politikai vezetéskutatás egyik nagy kérdése. Erre mutat rá az egyre táguló szakmai diskurzus és érdeklődés, amely egyaránt vitára késztet vezetéskutatókat és elméletalkotókat. A demokrácia és a vezetés közötti ellentét - amelyet az egyszerüség kedvéért a továbbiakban a demokratikus vezetés problémájának nevezek - viszont nem merülhet ki az elméleti polemizálásban. Ugyanis már egy gyakorlatban felbukkanó problémára hívják fel a figyelmet azon politikai történések, amelyek újra és újra felszínre hozzák a demokráciákban az állampolgárok politikai vezetéssel kapcsolatos vágyait (,,Yes we can”, ,Wir schaffen das”, ,Stable and strong leadership”) és félelmeit (,Not my President”). Ebből kifolyólag a jelen kutatás erősen problémavezérelt (Shapiro 2005), hiszen olyan kérdéssel kell szembenéznie, amely túlmutat a látszólagos elméleti diszkrepancián és ténylegesen meghatározza a politikai vezetés aktuális irányát, tartalmát, valamint a vezetők és a követők viszonyát. Ennek az elméleti és gyakorlati problémának a vizsgálatára és feloldására vállalkozik a kutatás.

A dolgozat fő kérdései röviden úgy fogalmazhatók meg, hogy: „Miképpen oldható meg gondolati (elméleti) szinten a demokratikus vezetés problémája?”, illetőleg „Miképpen oldódik meg az a gyakorlatban?”. Figyelembe véve a problémát taglaló szakirodalmat a disszertáció újszerű és hiánypótló jellege a probléma feloldásának irányában és módjában mutatkozik meg. Ez három ponton is tetten érhető. Egyrészt arra a tézisre építem érvelésem, hogy a vezetés és a demokrácia nem csak, hogy nem mondanak ellent egymásnak, de a fogalmakat és a gyakorlatot tekintve függenek is egymástól. Ez meghaladja a szakirodalom a fogalmak kibékíthetőségére vonatkozó érvelését. Másrészt egy olyan két perspektívát is magában foglaló konstruktivista megközelítésre alapozom a vizsgálódást, amellyel átfogom az elméleti és gyakorlati szinten jelentkező problémát. Végül, harmadrészt a kutatás explicit céljaként egy demokráciaelméletekből leszürt vezetéstipológiát állítok föl, amely az empirikus elemzés során heurisztikai eszközként kerül majd alkalmazásra, lehetővé téve a probléma plurális olvasatát. Vállalkozásom 
tétje épp abban a felismerésben rejlik, hogy a problémának nem csak elméleti, de gyakorlati relevanciája is megkerülhetetlen.

Mielőtt azonban kérdéseim megválaszolásába, illetve a tipológia kialakításába és alkalmazásába belekezdenék az alábbi fejezetben kibontom a kiinduló kutatási problémát, meghatározom a kutatás keretét és menetét.

\subsection{A kutatási probléma}

A demokratikus vezetés inkoherens fogalomként, oximoronként vagy egyenesen paradoxonként jelenik meg a tudományos diskurzusban (Beerbohm 2015; Kane és Patapan 2012; Keohane 2010, pp. 155-193, 2016; Ruscio 2008; Teles 2012). A politikai vezetés ambivalens helyzete elsősorban abban rejlik, hogy az ideális demokrácia elképzelése nem türi meg a vezetés gyakorlatát. Pontosabban: amíg a demokrácia fogalma egybeforrt az önkormányzás, a népszuverenitás és az egyenlőség ethoszával, addig a vezetés gyakorta úgy jelenik meg, mint a hatalom, a hierarchia, a manipuláció, és így az egyenlőtlenség letéteményese. Ily módon ez az „erős” vezetés csak gyengítheti a demokráciát.

Noha a demokratikus vezetés problémája nem teljesen ismeretlen a politikaelmélet számára (ambiguity of leadership: Dahl 1961; ambivalence of executive power: Mansfield 1989), mégis erőteljes gyanakvás és „félelem” övezi, ezért nem vagy csak igen ritkán jelenik meg az elméleti diskurzusban (Kane és Patapan 2012, pp. 10-30; Ruscio 2008, p. ix). A félelem két ponton is kitapintható. Egyfelől a vezetéstől való félelem kielégítő és legitim igazolása lehet a demokratikus kormányformáknak, intézményeknek és procedúráknak, ugyanis könnyen bebizonyosodhatnak azon aggodalmak, miszerint a vezetők visszaélnek a hatalmukkal. Ennélfogva szükségesnek tünik a vezetésnek bizonyos elvek és intézményi keretek mentén történő korlátozása, valamint az állandó legitimációs igény fenntartása. Másfelől ugyancsak komoly veszélyt jelent, ha a népszuverenitás gyakorlata vagy az intézményi vétópontok, a hatalommegosztás, a fékek és ellensúlyok rendszere ellehetetlenítik a vezetést, a kormányzást. A vezető számára nehézkessé, vagy akár lehetetlenné válik, hogy a közösség, a csoport többsége által kívánatosnak tartott célokat elérje. Így a demokratikus vezetésnek egyszerre kell rendelkeznie nagy befolyással, hatalommal és ezzel egy időben kell mások - a nép, a többség, vagy épp a törvényhozás - akaratát is szolgálnia. A demokratikus vezetés tehát egyszerre erős és gyenge, ugyanis a vezetőt a legitimációs igénye egyszerre ruházza fel hatalommal, és korlátozza is abban, hogy elérje céljait (Kane és Patapan 2012; Keohane 2010, pp. 155-93). 
Ez a demokratikus vezetésben rejlő ellentmondás azonban - ahogy azt számtalan munka (ld. például: Beerbohm 2015; Kane és Patapan 2012, 2014; Kane, Patapan, és 't Hart 2009; Keohane 2016; Metz 2017b; Ruscio 2008; Teles 2012, 2015; E. T. Weber 2010; Wren 2007) aláhúzza - nem kérdőjelezheti meg a politikai vezetés létjogosultságát a demokráciában. Így a kérdés nem az, hogy a vezetés szükséges-e a demokrácia müködéséhez, hanem az, hogy a vezetés mely formája lehet összeegyeztethető a demokrácia egy adott ideájával. A vezetésről alkotott kép erősen függ attól, hogy a demokrácia mely ideáját kívánja a kutató impliciten vagy expliciten védeni és érvényesíteni (Ruscio 2008, pp. 4-6), s fordítva a demokrácia mely meghatározása fér össze a politikai vezetés szükségszerüségével. Az ellentmondás tehát feloldhatónak tünik, ha a vezetés és a demokrácia koncepcióját megfelelőképp szabjuk egymáshoz (Beerbohm 2015, p. 639). A vezetés- és politikaelméletek a demokratikus vezetés problémájának megoldására három stratégiát vázolnak fel, különbözőképp békítve ki a fogalmakat.

Az első stratégia a demokrácia egy meghatározott ideájához kívánja illeszteni a vezetést. Másik irányból megközelítve: a morális vezetés helyét keresi a demokráciában. A demokratikus vezetés ebben az értelemben meghatározott morális kötelességként jelenik meg. Eric Thomas Weber megfogalmazása találóan jeleníti meg ezt a logikát: „a demokratikus politikai vezetőknek szükséges elköteleződniük a demokratikus értékek, a többség akaratának érvényesítése és a politikai kisebbségek jogainak védelme mellett" (E. T. Weber 2010, p 105). Egyes szerzők (B. R. Barber 1989, 2004, pp. 237-42; Gastil 1994; Kuyper 2012; Ruscio 2008; Uhr 2005) a deliberatív és részvételi demokrácia müködésében szánnak a vezetés egy bizonyos formájának elengedhetetlen szerepet. Bár a vezetés ellentétes a részvételen alapuló önkormányzással, s így logikus következtetés lenne annak eliminálása, mégis az elengedhetetlen a demokratikus keretek kialakításához és fenntartásához (B. R. Barber 1989, 2004, pp. 237-47; Gastil 1994). Tökéletes példa erre Nannerl O. Keohane (2010, pp. 155-193, 2016) gondolatmenete, amelyben az egyenlőség ideáját és az egyenlőtlenséget, a hatalmat magában hordozó vezetés ellentétét igyekszik kibékíteni azzal, hogy a vezetés számára feladatként a demokrácia fenntartását és az egyenlőtlenség kezelését írja elő. Ennél mélyebb demokráciaelméleti fejtegetésében Kenneth P. Ruscio (2008) a vezetés célját a liberális demokrácia megerősítésében és érvényesítésében határozza meg. Értelmezésében a jó demokratikus, rawlsi liberális erényekkel felvértezett vezetők képesek meghaladni az állampolgárok apátiáját, elősegíteni a „közös gondolkodást” (public reason), amelynek folyományaként megnő a bizalom; illetőleg képesek érvényesíteni a közérdeket a 
magánérdekek háttérbe szorításával, és elérhetővé tenni a közjót. Érdemes itt megemlíteni még John Uhr (2005) unikális megoldását is, ami az etikus vezetésbe vetett bizalom alapjait (alapelveit és mechanizmusait) kívánja megszabni. Amellett foglal állást, hogy a deliberációt elősegítő demokratikus vezetést nem lehet kizárólagosan a vezető helyes döntéseire és erényire alapozni, azt szükségképpen intézményi korlátoknak kell kikényszeríteniük.

A második stratégia egy köztes megoldást keresve kívánja kibékíteni a vezetés szükségszerüségét és a demokrácia morális elvárásait. Másképp fogalmazva ezen megoldási kísérletek már a hatékony és morális vezetést keresik a demokráciában. A szerzők a vezetésnek egy némiképpen stabilabb és szélesebb fogalmával dolgoznak, amely a hatékony vezetés iránti igény gyakorlati tapasztalatából táplálkozik. Ebből a nézőpontból elkerülhetetlennek tünik, hogy egyes politikai szereplök nagyobb befolyással rendelkezzenek, mint a többiek (Dahl 1961; Downs 1957, pp. 87-88). Így ugyan a demokrácia müködéséhez elengedhetlennek látszik a vezetés (Beerbohm 2015; Downs 1962; McFarland 1969; Olson 1971, pp. 174-78), mégis szükségszerü annak korlátozása (Dahl 1956, p. 3). Másképp fogalmazva: a demokrácia nem engedheti meg magának, hogy feláldozza a reszponzív kormányzást egy hatékonyabb, kreatívabb vezetésnek teret engedve (Downs 1962, p. 36). Erre tapint rá Helms (2014) munkájában mikor felhívja a figyelmet arra, hogy bár a demokratikus intézmények megakadályozzák, hogy a morális értelemben rossz vezetés kialakuljon, mégis azok könnyen előhívhatják a rossz vezetés egy másik oldalát: a nem hatékony vezetést. Ebből a szemszögből a kérdés így az lesz, hogy miképpen érvényesülhet a vezetés a demokratikus politikában.

Ezt a kérdést bontották ki nagy ívű vállalkozásukban John Kane és szerzőtársai. Első kötetükben (Kane, Patapan, és 't Hart 2009) feltárták azokat, a demokratikus kormányzásra hatással lévő tendenciákat, amelyek decentralizálják a vezetést, azaz szétosztják azt, mint funkciót, szerepet a társadalomban. Később, John Kane és Haig Patapan (2012) már a politikai vezetés azon kihívásait veszik számításba, amelyek a demokratikus elvek betartásából fakadnak. Rámutatnak arra a feszültségre és súlyos teherre, amely a szuverén hatalom gyakorlásából és a vezetés reprezentatív szerepéből fakad. Megközelítésükben a magas morális igények és a hatékony vezetés kívánalma között keresnek arany középutat, amellyel elutasítják a demokrácia elitista és a részvételt kiterjesztő egalitárius értelmezését. Ezen az úton továbbhaladva a harmadik kötetükben (Kane és Patapan 2014) a jó vezetés lehetőségeit vizsgálják a 
demokráciában, amely során arra a kérdésre keresik a választ, hogy miként lehet elősegíteni és biztosítani a ,jó vezetés” gyakorlatát, illetve azt mennyire segítik, és mennyiben nehezítik a demokratikus elvek. A vezetés felől megközelítve tehát itt azon jellegzetességek kerülnek kihangsúlyozásra a követőkhöz füzött sajátos viszony, a döntéshozatal és a közérdek kapcsán, amelyeket a demokratikus politikai környezet követelményként támaszt a vezető elé (ld. még: Helms 2012c; Teles 2015).

Ehhez képest a harmadik megoldási stratégia képviselői némiképp más irányból közelítik meg a demokratikus vezetés kérdését. E munkák a ,jó”, mint hatékony vezetést (a „vezért”) keresik a demokráciában, így a nagy történelmet, politikát formáló vezetőre fókuszálva alacsonyabb morális elvárásokat megfogalmazva. Leegyszerüsítve: itt a vezetéstől függ a demokrácia, s nem a demokráciától függ a vezetés. S ilyen értelemben a vezér teszi lehetővé és tartja mozgásban a demokráciát, és nem fordítva. A szerzők egy része (Lord 2003; Philp 2007; Schabert 2013) Machiavelli fejedelmének helyét keresik a modern demokratikus környezetben, valamint az erényes államvezetés művészetét és a kormányzás gyakorlatát írják le. Ugyancsak jelentős azon kutatások köre (Brooker 2010; Körösényi 2005; Pakulski és Higley 2008; Pakulski és Körösényi 2012) is, amelyek Max Weber és Joseph A. Schumpeter „minimalista” felfogású demokráciaelméletének értelmezési keretében hangsúlyozzák a vezetés kritikus szerepét a politikai folyamatokban.

Áttekintve a szakirodalom megoldási stratégiáit, jól kirajzolódik, hogy a „,helyesen felfogott" vezetés és demokrácia fogalma kibékíthető és az előttük támasztott elvárások erősen összefüggenek. A különböző megközelítések eltérő módon kezelik a demokrácia és a vezetés fogalmát, $s$ tekintik egyiket és/vagy a másikat fogalmilag kötöttnek és ennek megfelelően határozzák meg azokat szélesebb értelemben. Az első megközelítési stratégia a morális vezetést keresi a demokráciában. Ezen kutatások a demokrácia egy normatív értelemben széles és stabil értelmezéséből indulnak ki és vezetik le a vezetésértelmezésüket. Másképp fogalmazva: a vezetést igazítják fogalmilag a demokrácia ideájához. A második csoportba tartozó megközelítések már a vezetés érvényesítésére és korlátozására fokuszálnak. A demokratikus vezetésnek itt egyszerre kell morális és hatékonysági elvárásoknak megfelelnie. A szerzők a vezetés egy kötöttebb koncepcióját adják meg a demokrácia meghatározott körülményei és elvárásai viszonylatában. Azaz: a vezetést és a demokráciát egyszerre tekintik fogalmilag adottnak és kívánják azokat összekapcsolni. Ezzel szemben a harmadik megoldási stratégia, mely a jó vezetőt keresi a demokráciában, egy széles és stabil vezetésképnek 
kívánja alárendelni a demokrácia fogalmát. Így, amíg a demokrácia szubsztantív tartalma leszükül, addig a szerzők a vezetés hatékonyságával kapcsolatosan fogalmaznak meg magasabb elvárásokat.

A három stratégia mindegyike feloldja valamilyen módon az elméleti problémát, de belső logikájuk nyomán csak korlátozottan képesek választ adni a demokratikus vezetés problémájára. Azzal, hogy a vezetést és/vagy a demokráciát fogalmilag megkötik, nem csak leszűkítik a megértést, de diszkreditálnak és delegitimálnak olyan demokratikus vezetési gyakorlatokat, amelyek egy másik nézőpontból elfogadhatók, sőt akár szükségesek is lehetnek. Így, amíg az egyik vezetés könnyen „antidemokratikussá” válhat, addig más vezetői tevékenység és teljesítmény nem minősülhet „igazi” vezetésnek. Mindez két veszélyt is magában rejt: egyfelől a demokratikus vezetésről való gondolkodás elszakadhat a valóságtól és absztrakt szinten ragadhat, másfelől viszont az - éles határt húzva a demokratikus és a nem-demokratikus vezetés közé könnyen átcsúszhat a politikai közbeszéd területére a vezetés gyakorlatának értelmezése során.

\subsection{A kutatás tézise}

Tézisem szerint a demokrácia és a vezetés fogalmukat és a gyakorlatot tekintve is kapcsolódnak. A fogalmak tehát nem csak kibékíthetők egymással, hanem szorosan is függenek egymástól. Azaz: nincs demokrácia (helyesen felfogott) vezetés nélkül s fordítva.

A fogalmi kapcsolat felfejtésére vállalkozik J. Thomas Wren (2007) „A vezetés feltalálása. A demokrácia kihívása" (Inventing Leadership. The Challenge of Democracy) címü kötetében, amely a kutatás kiindulópontjának számít. Munkájában Wren feltárja a vezető és a vezetés konstrukciójának történeti és társadalmi hozadékát azzal, hogy eszmetörténeti időszakokra bontva rekonstruálja egyes elméletalkotók és filozófusok ,implicit vezetés elméletét”. Ezeket az implicit elméleteket, amelynek fogalmát a szociálpszichológiai vezetéskutatás keretéből kölcsönözte, a vezetés természetét feltáró kérdések mentén alkotja meg. Összességében a szerző amellett foglal állást, hogy a vezetésről és a modern demokráciáról való gondolkodás és diskurzus fejlődése párhuzamos. ${ }^{1} \mathrm{~S}$ bár az eszmetörténeti fejtegetésére ehelyütt nincs lehetőség

\footnotetext{
1 Ha csak az angol „vezetés” (leadership) szó „pályafutása” kerül említésre, szembetűno, hogy az valójában csak 1818-ban jelent meg először az értelmező szótárakban, de követve a demokráciára vonatkozó igény fejlődését és terjedését, csak a 20. században vált állandó szócikké (Rost 1991, 38-44).
} 
kitérni ${ }^{2}$, fontos aláhúzni a szerző alapgondolatát, amely szerint a vezetés a kormányzók és a kormányzottak kapcsolatának, rendezésének egy új módját jelöli. Wren többször idézi Edmund S. Morgan történész szavait:

„A »vezető« szó régi, de a »vezetés« olyan kifejezés, amelyet úgy tünik senki sem érzett szükségesnek mindaddig, amíg az általa jelölt minőség a társadalmi felsőbbrendűség hozadéka maradt. A vezetést övező tisztelet és emelkedettség hanyatlása nemcsak egy új retorikának a kezdetét jelentette, hanem a társadalmi kapcsolatok és annak meghatározásának az új módját, hogy ki tartozzon a sokakat kormányzó kevesek közé." (ford., kiemelés tőlem) (idézi: Wren 2007, pp. xii; 3; 132)

Így azzal, hogy a fókusz a vezetőről a vezetés fogalmában a politikai rendszer összes tagjára helyeződik, feloldódni látszik a demokratikus vezetés problémája.

A vezetéskutatásban a vezetés és a demokrácia közötti kapcsolat nem jelent természetesen új felfedezést, ahogy arra Wren (2007, pp. 133-34) is emlékeztet. Például Alvin W. Gouldner (1950, p. 4) értelmezése szerint a vezetés jelensége egyenesen a demokratikus világ terméke. Másképpen fogalmazva a szerző állítását: a vezetés olyan jelenség, amelyet a modern demokratikus értékek kondicionáltak. Olyan elgondolások kapcsolhatók hozzá, amelyeket számos, manapság divatos, motivációs és „önfejlesztő” könyv is sugalmaz: „vezetni bárki tud”, vagy „a vezetés tanulható”, azaz ahhoz, hogy vezetők legyünk, nem szükséges „kiváltságosnak” lennünk, vagy akár „jó helyre” születnünk. James MacGregor Burns (1978, p. 25) összeköti a vezetésről folyó diskurzust a hierarchikus világ hanyatlásával. Értelmezésében a vezetés a kormányzók és kormányozottak kapcsolatának egy merőben új módját jelöli, amely már nem fér össze a régi világ merev hierarchikus felépítésével. Így már pontosabb megfogalmazásnak tünik a vezető és követők kategóriájának használata, amely dinamikusabb és nem kizárólagos, állandósult és statikus kapcsolatot feltételez.

A fogalmi kapcsolódást és „egymásrautaltságot” erősíti, hogy mindkét fogalom tartalmát tekintve igen bizonytalan és mint társadalmi konstrukciók függenek az adott tudományos diskurzustól és politikai kontextustól. A megannyi értelmezés jól példázza a fogalmak bizonytalanságát. Amíg Joseph C. Rost (1991) az 1900-1990 között publikált 587 vezetéssel foglalkozó munkát áttekintve összesen 221 különbözö definíciót talált, addig Jean-Paul Gagnon és kollégái (2014; ld. még erről: Collier és

\footnotetext{
${ }^{2}$ A vezetés eszmetörténeti vizsgálatával kapcsolatban lásd Wren (2007) említett munkáját és Harvey C. Mansfield (1989) a kormányzás problémájára fokuszáló kötetét.
} 
Levitsky 1997) a demokráciának nem kevesebb, mint 507 különböző formáját, fajtáját gyüjtötték össze. Mindez arra mutat rá, hogy mindkét fogalom ,lényegüket tekintve vitatott koncepciók" (essentially contested concept: Gallie 1955/56). Mind a demokrácia (Gallie 1955/56; ld. még erről: Collier, Hidalgo, és Maciuceanu 2006), mind a vezetés (Grint 2005a, pp. 17-19) fogalma természetüknél fogva elkerülhetetlenül és elválaszthatatlanul magukban hordozzák azokat a vég nélküli vitákat, amelyek középpontjában a használatuk helyessége áll. Az ilyen fogalmak igen összetettek és így különbözőképp ragadhatók meg. Jelentésüket tekintve nyitottak, amelynél fogva periodikusan revízió tárgyává válhatnak, a kontextustól és annak változásától függően. A fogalmakat övező konfliktusban a különböző jelentésváltozatok rivalizálnak és versenyeznek egymással azt illetően, melyik a helyes értelmezés.

Találóan fogja meg ezt a fogalmi bizonytalanságot Koselleck és munkatársai (1999), mikor a demokráciát az egyetlen ,jó” politikai rendszert leíró „univerzális bálványfogalomként" határozzák meg. Értelmezésükben a koncepció története során egy olyan „,mindent jelölő fogalommá”, „üres formulává” vált, amely:

„mindenkor telíthető különböző, sőt ellentétes tartalmakkal is, oly módon, hogy belőle vagy különféle megvalósulásainak pluralizmusa vezethető le, vagy az az igény, hogy mint »igazi« avagy (...) »magasabb típusú« demokráciát, abszolút módon tételezzék és kizárólagosan képviseljék.” (Brunner, Conze, és Koselleck 1999, p. 156)

Ez azt jelenti, hogy a demokrácia idealisztikus, utópisztikus jellegénél fogva egyfajta hit tárgyává válik (ld. erről: Deneen 2005). Ahogy Max Weber (1987, p. 222) is aláhúzza: az uralom - függetlenül annak tartalmától - a legitimitásába vetett hiten alapul. Mindebből az következik, hogy a demokrácia olyan általános politikai vallást, hitet testesít meg, amelyet örök ígéretként nem lehet teljesíteni, de amely felé mégis szükséges, megkerülhetetlen kívánalom törekedni.

Wren (2007) amellett érvel, hogy a demokrácia és a vezetés olyan egymással szorosan összefüggő társadalmi és történeti konstrukciók, amelyek megkívánják, hogy az állampolgárok bizonyos ideákban higgyenek: a megválasztott vezetők bölcsek és erényesek, vagy épp az állampolgári részvétel elengedhetetlen és valós hatással van a politikára. Ebböl kifolyólag a demokratikus vezetés elkerülhetetlenül azon elgondolásokat és hitet süríti magában, amelyeket egy adott politikai közösség a legjobb kormányformáról és a jó kormányzásról vall. Természetesen nem feltételezhető, hogy ezeket illetően mindenki határozott és részletekbe menő meggyőződéssel rendelkezik, 
azonban több mint valószínű, hogy a legtöbb embernek van arról véleménye, hogy miként kellene a közösség ügyeit rendezni, a közösség életét vezetni, illetőleg kire kellene mindezt bízni.

A demokrácia és a vezetés fogalma között így egyfajta párhuzam jön létre. Ha a demokrácia széles értelemben olyan rendszerként definiálható, amely a kormányzók és kormányzottak kapcsolatát egyedi módon szervezi meg (Schmitter és Karl 1991, pp. 76-77), és ha a vezetés egy olyan befolyásolási pálya a vezetők és követök között, amely meghatározott célok eléréséért jött létre, akkor a vezetést a demokrácia gyakorlataként $^{3}$ értelmezhetjük (Wren 2007, p. 2). A vezetés a demokrácia gyakorlataként értelemmel és tartalommal telíti a demokratikus politika folyamatát:

„A vezetés egy olyan konstrukció, amely azt keresi, hogy miként lehet kibékíteni ezt a dilemmát a vezetők akciói, strukturális korlátok és a helyénvaló folyamatok kiaknázása révén. Hasonlóképp, a helyesen felfogott vezetés kibékíti a demokráciában azt a feszültséget, amely az erős és látnoki vezetők iránti vágy és a részvétel, egyenlőség és sokszínűség értékeit illető mély elköteleződés között húzódik. Röviden: a vezetés, mint egy konstrukció és egy valóság azt ígéri, hogy ő jelenti a kulcsot egy életképes és müködő demokráciához ebben a posztmodern világunkban.” (ford., kiemelés tőlem) (Wren 2007, p. 1)

De mit is jelent mindez a gyakorlatban? A demokratikus vezetés maga is „,bálványfogalommá” válik, hiszen a vezetésnek társadalmi konstrukcióként igazolnia kell létét a demokráciában. A demokratikus vezetés problémája így megoldódik azzal, hogy a vezetés teljesíti önigazolási kötelezettségét. Ezen ellentmondások a vezetéskutatás két klasszikus dilemmájában ragadhatók meg:

1. Milyennek kell lennie a ,jó’ vezetésnek? A vezetés legyen-e hatékony a közös és akár a saját céljainak elérésében, vagy feleljen-e meg inkább bizonyos morális elveknek és alapértékeknek? (ld. erről: Ciulla 2018)

2. Milyennek kell lennie a vezetök és követők közötti ,helyes” (helyénvaló) kapcsolódásnak és szerepelosztásnak? A vezetés és a politika folyamatára a

\footnotetext{
3 Fontos megjegyezni, hogy a kutatás megközelítésben a vezetés nem értelmezhető az autokrácia gyakorlataként. Egy autokrácia nem szükségképp igényli a vezetés gyakorlatát. Mivel vezetés, a követők mobilizálása költséges és eredménye esetleges, itt a vezetés helyét és funkcióját átveszi az uralkodás, az irányítás és a parancsuralom, amelyek beláthatóbb és biztosabb módon fejtenek ki hatást a politikai folyamatokra. Erről a problémáról lásd bővebben az 1.3.2. és 1.3.3. fejezetet!
} 
vezetők vagy a követők legyenek-e nagyobb befolyással? („Burns Paradox”: Burns 2003, pp. 170-185)

A ,helyesen felfogott” vezetésnek tehát valamilyen válasszal kell szolgálnia ezekre a kérdésekre. Ezzel a vezetés a demokrácia gyakorlataként formatív és konstitutív módon hozzá is járul a demokráciáról alkotott meggyőződéseinkhez. Másképpen fogalmazva: a vezetés olyan alkotó tevékenység, amely szükségszerüen meg kell, hogy teremtse a maga demokratikus valóságát és belső igazolását, igazodva a demokráciával szemben támasztott elvárásokhoz. A demokratikus politika legitimitásigénye rákényszeríti a vezetőket erre az állandó alkotó tevékenységre. Ez két dolgot is jelent: egyrészt a demokrácia állandó igazolásának kívánalmát kizárólag a vezetés képes megteremteni, másrészt a vezetést a népuralomból, a népszuverenitásból fakadó konstans legitimitásigény maga is formálja. Ily módon az állandósult belső igazolás igénye mellett, a demokrácia gyakorlataként a vezetés megtestesíti a demokráciában rejlő központi dinamikát és rugalmasságot.

Itt válik különösen kritikussá a demokratikus vezetés szerepe, hiszen tartalmától függően valamilyen módon hozzájárul a demokratikus politika folyamatához. A demokráciába vetett hitet közvetlenül a vezetés alakítja: a politikai vezetők „papokként”, a követők, állampolgárok, „hívőkként” hirdetik és építik a politikai „,öldi paradicsomot”, a demokráciát, és a jó demokratikus vezetést. Ennélfogva a vezetők és a vezetés - ahogy Graham Little szavai különösen jól megfogják - szerepe kritikus:

„A politikai vezetés olyan jelentőségre tett szert korunkban, mintha a politikának és annak vezetőinek be kellene tölteniük azt a teret, amelyet Isten és a vallás hagyott maga után. A pártvezetők, a miniszterelnökök vagy az elnökök a szimbólumaivá váltak annak, akik vagyunk: megszemélyesítik életmódunkat és legmélyebb hiedelmeinket.” (ford. tőlem) (Little 1988, 2)

A demokratikus vezetés és vezető ígérete egyszerü: „higgyetek nekem, mert én ismerem és gyakorlom is a demokratikus politikát”. Sőt az állandó és egymással versengő mobilizálás révén, a demokratikus politikától elválaszthatatlan a megváltás gondolata (Canovan 1999), ${ }^{4}$ amely az adott politikai közösség életének javulásának ígéretét és reményét fogalmazza meg. Ebből a szemszögből a vezetést nem lehet kizárólagosan a „lehetséges müvészeteként” definiálni, amely a hatalomra és az intézményekre

\footnotetext{
${ }^{4}$ Canovan (1999) pragmatista és megváltó demokratikus politika megkülönböztetését Michael Oakeshott fogalompárjára (a hit - és a kételkedés politikája) alapozta (ld. erről: Canovan 1999, pp. 8-9; Deneen 2005, p. 49).
} 
összpontosul, hiszen a demokratikus politika igényli azt az ,álmodozást” és hitet, amelyhez a vezetés, mint a „lehetetlen müvészete” (pragmatic vs. redemptive politics: Canovan 1999; realpolitik vs. dreampolitik: Duncombe 2007, 2012) kapcsolódik.

A vezetők által életre keltett és életben tartott, a demokratikus vezetésről alkotott idealizált elképzelések természetüknél fogva nem fedhetik le teljesen a való világot, de nem is szakadhatnak el teljesen a valós élet tapasztalataitól. Így az „antidemokratikusnak” ítélt vezetők nem hasonlíthatnak az Andersen által megfestett császár helyzetéhez, akiről egy gyanútlanul megszólaló kisgyermek leleplezheti az „,igazságot”: „A császár meztelen!" vagy ebben az esetben „A vezetés antidemokratikus!”. Másképpen fogalmazva: a „nem-demokráciát” vagy az ellentétes demokráciát nem lehet egyszerü visszautasítással felfedni (Brunner, Conze, és Koselleck 1999, p. 156). Ugyanis nem létezik objektív, mindenki számára kézenfekvő és hozzáférhető mérce a kérdés megítélésére. Azonban egy adott demokratikus vezetés sem lehet kizárólag a vezető képzeletének a szüleménye, de nem is elvárás, hogy mindenki higgyen benne. Az viszont szükségesnek tünik, hogy egyesek határozott meggyőződést, hitet tápláljanak azt illetően, hogy az adott vezető megtestesíti a jó vezetésről, a helyes szerepelosztásról és a demokráciáról vallott elképzeléseiket.

\subsection{A kutatás előfeltevései és fogalomhasználata}

A tézisemet három előfeltevésre alapozom. Az első előfeltevésem szerint a konceptuális sokszínűség ellenére a vezetés rendelkezik egy stabil denotációval. S így nem lehet leválasztani róla a hatásgyakorlást (cselekvést), a vezető és a követök közötti kapcsolatot és interakciókat. A második elöfeltevésemmel arra mutatok rá, hogy a vezetés nem feleltethető meg egy adott pozíció betöltésével (formális autoritással), s így a kormányzással és az elit kizárólagos cselekvésével. A harmadik előfeltevésem a vezetés normatív konnotációját fogja meg, amelynek fényében rendezhető a fogalom viszonya a hatalommal. A három előfeltevésből az is kitünik, hogy arra is rámutat, hogy a vezetés fogalmából egyenesen következik a ,jó" vezetés és a vezetők és követők közötti „helyes” kapcsolat problematikája. A megfogalmazott elöfeltevéseim tisztázását két értelmezési csapda indokolja, amely nem csak áthatja a demokratikus vezetés problémájára fokuszáló stratégiákat, de meghatározza a vezetéskutatás egészét is. Az elkövetkezőkben ezeket tekintem át részletesebben. 


\subsubsection{Első előfeltevés: a fogalom denotációja}

Közhelynek tünik, de igaz lehet az az állítás, hogy a vezetést könnyebb felismerni, mint definiálni. Ez a vezetéskutatásban állandó problémaként jelenik meg. Egyes szerzők (Burns 1978; J. W. Gardner 1990; Rost 1991) úgy gondolják, hogy kizárólag csak egy általános fogalmi kerettel lehetséges a vezetés mélyebb megértése. Fontos azonban látni, hogy a kutatók fogalmaikat kizárólag tudományos céllal alkotják meg, amellyel nem feltétlenül kapcsolódnak a hétköznapi jelentéstartalomhoz, sőt néha el is szakadhatnak attól. Joanne B. Ciulla (2014b, pp. 12-16) rámutatott, hogy a vezetés szó használata és az arról való gondolkodás meghatározza annak jelentését. A szó denotációja - legalábbis az angol nyelvben - stabil. Így annak ellenére, hogy a szerzők eltérőképp használják a fogalmat, tudják mit jelent és mire utal.

Ezzel párhuzamosan a vezetés egy társadalmi konstrukció is, így a különböző értékek, vezetési gyakorlatok és paradigmák adott helyen és időben eltérő variációkat eredményezhetnek. Egy történeti perspektívából szemlélve - ahogy Joanne B. Ciulla (2014b, pp. 12-16) is teszi - a definíciók követik a korszellem elvárásait a vezetés szerepét, célját és eszközeit illetően, mégis a megfogalmazások között wittgensteini családi hasonlóságok (family resemblances: Ciulla 2014b, pp. 13-14; Shapiro 2014, p. 128) fedezhetők fel. A különböző definíciók számos jellegzetességet felsorakoztathatnak, de nem szükséges egy meghatározó közös pont, annak elfogadásához, hogy azok egyazon cselekvési körre mutatnak rá.

Áttekintve néhány példát a politikai vezetés definíciójára mindez szembetünik. Lewis J. Edinger (1967, p. 15) például igen átfogóan fogalmaz:

„A vezetés egy olyan pozíció a társadalomban, amely az alapján rögzül, hogy az inkumbens mennyire képes irányítani, strukturálni a kollektív cselekvési mintákat (...) [A vezetés] minden esetben relacionális, interperszonális; és azon - a vezető és a követők közötti - befolyásbéli egyenlőtlenségen alapul, amelyben a vezető a követők magatartását úgy akarja módosítani, hogy illeszkedjen saját személyes céljaihoz." (ford., kiemelés tőlem)

Glenn D. Paige (1977, p. 1) hasonló képet fest a vezetésről, amely értelmezésében a „hatalmi pozíciót betöltő személyek és vetélytársaik viselkedése és interakciói egymással és a társadalom többi tagjával” (ford., kiemelés tőlem). Robert C. Tucker (1995, p. 11) szerint „,[a] vezetés emberi interakciók folyamata, amelyben néhány egyén meghatározó befolyást gyakorol, vagy gyakorolni próbál mások felett" (ford., kiemelés 
tőlem). Hasonlóképpen látja Barbara Kellerman (1984, p. 70) is a vezetést, amely akkor nyilvánul meg, ha „egy személy konzisztens módon nagyobb hatást gyakorol, mint mások a csoportaktivitás természetére és irányára” (ford., kiemelés tőlem). John W. Gardner (1990, p. 1) értelmezésében a vezetés olyan „meggyőzési folyamat vagy példamutatás, amellyel egy egyén (vagy vezetői csoport) egy csoportot arra késztett, hogy elérjenek a vezető által felvállalt vagy a vezetők és a követőik által közösen osztott célokat." (ford., kiemelés tőlem) Ebből az irányból közelítve Joseph S Nye (2008, p. 18) a vezetőket azon személyekben határozza meg, ,akik egy csoportot segítenek közös céljaik megkreálásában és elérésében” (ford., kiemelés tőlem). Burns (1978, p. 18) szerint a vezetés akkor jön létre, amikor egyes határozott motivációkkal és célokkal rendelkező személyek mobilizálnak bizonyos intézményi, politikai, pszichológiai vagy más forrásokat egy versenyhelyzetben vagy konfliktusszituációban azzal a szándékkal, hogy felkeltsék, majd ki is elégítsék követőik igényeit, ezzel bevonva őket a folyamat(ok)ba. Később pontosítja megfogalmazását: „[a] vezetés egy reciprok folyamat, amelyet verseny- és konfliktusszituációban bizonyos motivációkkal, értékekkel, különböző gazdasági, politikai és más forrásokkal rendelkező személyek kezdeményeznek annak érdekében, hogy a vezetők és a követők közösen, vagy egymástól függetlenül realizálják céljaikat.” (ford., kiemelés tőlem) (Burns 1978, p. 425) A burnsi gondolatot követve Rost (1991, p. 102) úgy fogalmaz, hogy a „,vezetés egy befolyásolási kapcsolat a vezetők és követők között, akik valódi változást kívánnak elérni közös céljaik érvényesítéséért" (ford., kiemelés tőlem).

Ezen definíciók kiugró mértékben nem térnek el egymástól annak ellenére, hogy a megfogalmazások különböző elemeket hangsúlyoznak - mint például a hatalmi pozíciót, az interakciókat, befolyásgyakorlást vagy a közös célokat -, ugyanis mindegyik egy olyan folyamatként, cselekvésként írja le a vezetést, amely kiváltja, hogy a követők bizonyos módon cselekedjenek.

Korábban úgy fogalmaztam, hogy a vezetés egy olyan befolyásolási pálya a vezetők és követők között, amely meghatározott célok eléréséért jött létre. Ez azt jelenti, hogy a vezetés a politikai folyamatokban bizonyos hatást és változást implikál és interperszonális kapcsolatokon alapszik. Ennek fényében a politikai vezető olyan formális vagy informális politikai pozícióban lévő személy: 
- aki nélkül bizonyos események nem, vagy legalábbis másképp történnének meg (Blondel 1987, p. 3; McFarland 1969, p. 155), vagy pontosabban fogalmazva: aki hat valamilyen formában a politika kimeneteli oldalára (Corwin 1978, p. 78, Edinger 1975 p. 257, 1993 p. 15; Kellerman 1984 p. 71), illetőleg

- aki interakciókon keresztül befolyásolja, motiválja és mobilizálja követőit egy specifikus irányba, azaz egy kívánt cél eléréséért (Burns 1978, p. 18; Kellerman 1984, p. 70; Paige 1977, p. 1; Rost 1991, p. 102; Tucker 1995, p. 11).

1. ábra: Az interakcionista paradigma fényében a vezetés fogalma

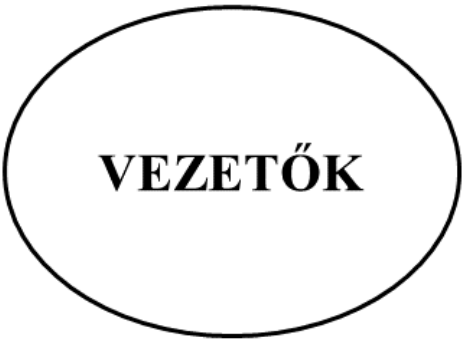

Politikai kontextus

(intézmények, szituáció)
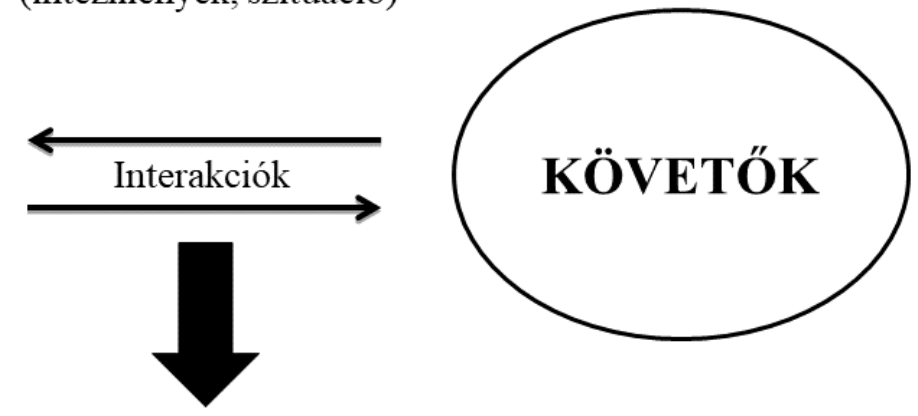

\section{VEZETÉS}

Forrás: Elgie 1995, 8 adaptációja

A politikai vezetéskutatás ebből az ún. ,interakcionista” paradigma (Elgie 2015, pp. 123) (1. ábra) keretéből logikailag nem képes kilépni. Ezen alapul a fogalom kötöttsége és viszonylag stabil denotációja. Elképzelhetetlen, hogy a vezető ne fejtsen ki valamilyen hatást; vagy, hogy mindezt a követők bevonása nélkül érje el; de az is, hogy a vezetés a politikai kontextus nélkül értelmezhető legyen. Másképpen fogalmazva: a vezetés fogalma elválaszthatatlan a politikai vezető személyétől, a követőkkel kialakított kapcsolatától és magától a politikai kontextustól. Ezek az elemek (a vezető, a követők, a kontextus) a cselekvés tartalmát tekintve kölcsönösen egymáshoz igazodnak, s ez a alkalmazkodás adja a vezetés irányát ${ }^{5}$. Ehelyütt azonban mindegy a kutatás számára, hogy milyen tartalommal bírnak az egyes elemek, milyen irányú és milyen

\footnotetext{
${ }^{5}$ Itt felmerülhet akár az ágencia és struktúra klasszikus ontológiai problémája (Hay 2002, pp. 89-134) is. Ez a vezetéskutatásban is széles körben felismert (Burns 2003, pp. 215-16; Hargrove 2004; 't Hart és Rhodes 2014; Jones 1989) dilemma arra mutat rá, hogy a vezetés folyamatát, irányát és kimenetelét illetően a vezető tevékenysége, vagy a cselekvés kontextusa (intézmények, követők) tekinthető a meghatározóbb elemnek. Erre azonban itt nincs módom részletesebben kitérni.
} 
hatással jár a cselekvés, valamint milyen kapcsolaton nyugszik a vezetés, ugyanis mindez erősen függ a (demokratikus) politikáról alkotott elképzelésektől. Ugyanakkor fontos látni, hogy e kérdések a ,jó” vezetés problémájára, illetve a vezetők és követők közötti „helyes” kapcsolódásra és szerepelosztásra mutatnak rá.

\subsubsection{Második előfeltevés: a fogalom határai}

A fogalmi kötöttségen túl fontos leszögezni, hogy a vezetést mely fogalmaktól szükséges analitikusan elválasztani annak érdekében, hogy kitisztuljon a kép a vezetés demokráciához füződő inherens viszonyát illetően.

A vezetéskutatásban - ahogy jellemzően a társadalomtudomány más területein is - az angol nyelv a domináns, s más nyelveken csak elvétve jelennek meg publikációk. ${ }^{6}$ Ennek az egyik, s talán legfontosabb oka abban rejlik, hogy az angol vezetés (leadership) kifejezésnek nincs tökéletes párja az újlatin nyelvekben, amelyből kifolyólag ez a kifejezés honosodott meg a tudományos és a politikai köznyelvben (a francia nyelvvel kapcsolatban ld.: Blondel 1987, pp. 12-13). Amíg az angol vezetés szó elsősorban egyfajta cselekvésre utal, addig, bár hasonló kifejezések megtalálhatók a latin eredetü nyelvekben is, mégis azok elsősorban föséget (ld. a francia chef és dirigeant vagy az olasz capo és dirigente főnevet) jelentenek, illetőleg magát a cselekvést a döntéshozatalra és a parancsolás aktusára szükíti le (ld. a francia diriger vagy az olasz dirigere igét). Ezt láttatja a politikai gondolkodásra igen nagy hatást kifejtő ógörög és latin nyelv, amelyben a vezetést jelölő igék (az ógörög ő $\gamma \omega$, ̋̋ $\rho \chi \omega$, $\dot{\eta} \gamma \varepsilon \dot{o} \mu \alpha \iota$ és a latin agere, gerere, ducere) katonai vagy politikai pozíció betöltésére és az uralkodásra utaltak. Ezzel szemben az angol ige az óangol leden vagy loedan szóból származik és „késztetni”, „,irányítani” és „irányt mutatni” igéket jelöli. Érdekes, hogy a német führen ige jelentésében közel áll az angol megfelelöjéhez, ugyanis egyszerre foglalja magában a latin ducere - kormányozni, igazgatni; vehere - jármüvet vezetni, járművel szállítani; gerere - vinni, viselni, birtokolni ige jelentéstartalmát (Grimm és Grimm 1999), mégis a Führer szót normatív értelemben terheli a Harmadik Birodalom vezérelve (Führerprinzip). A mellette használt negatív jelentéstartalmat nélkülöző Leiter főnév és leiten ige viszont már elsősorban egy vezetői pozíció betöltéséből indul ki.

\footnotetext{
${ }^{6}$ Például: a vezető amerikai folyóirat Presidential Studies Quarterly egyedül több cikket publikál a végrehajtói vezetésröl évente, mint az összes német politikatudományi folyóirat együttvéve az elmúlt negyed évszázadban (Helms 2012a, p. 493 4. lábj.).
} 
A magyar nyelvi kontextusban nincsenek ilyen torzító körülmények, így a vezetés lényegi megragadása sem ütközik komolyabb akadályba. A magyar „vezetni” finnugor eredetü ige elsődleges jelentése „kalauzol, kísér” (begleiten), és csak a másodlagos az „,irányít, igazgat” (führen), amely csak később rakódott rá. Az azonos szótőből származó vezényel (führen, kommandieren) ige vált katonai müszóvá. A vezér (Führer), mint társadalmi és katonai vezető, valamint a vezérel kifejezés jelöli a vezetés ellentmondást nem türő „kemény” árnyalatát (J. Juhász és Pusztai 2003). Ilyen értelemben a vezér kifejezés nem feleltethető meg egy az egyben a vezetővel, bár gyakran szinonimaként kezelik (ld. például Kiss 2016; Körösényi 2005; Metz 2014). Halmazokban gondolkodva: nem minden vezető vezér, de minden vezér vezető. A magyar nyelv így lehetőséget ad a kisebb változást ígérő, s talán kevésbé hatékony hétköznapi vezető és a hősként feltünő, nagy vezető: a vezér megkülönböztetésére. ${ }^{7}$

Mindebből a vezetés kifejezés két oldala rajzolódik ki: a vezetés az egyikben egy pozíció betöltését (headship/statesmanship), a másikban egy cselekvést (leadership) jelöl (Edinger 1975, pp. 255-56; J. W. Gardner 1990, pp. 2-3; Heifetz 1994; Kellerman 1984, pp. 70-71; Tucker 1995, pp. 1-30.). A formális pozíció betöltésének kiemelésével a vezetés bizonyos hatalmi apparátus, formális autoritás birtoklásával és használatával azonosítható. Ezzel szemben a cselekvés felől szemlélve a vezetés interperszonális jellege kerül kihangsúlyozásra, amely nem feltétlenül igényel formális autoritást. Azzal, hogy leválasztásra kerül a formális autoritás a vezetésről (Heifetz 1994; Tucker 1995 , pp. 1-30.) láthatóvá válik a kormányzás és vezetés közötti eltérés is (Helms 2012a, pp. 496-98). Általánosságban a kormányzás a közös ügyek intézéseként határozható meg, amely az állami- és magánszereplök közötti formális kapcsolaton, kölcsönös függőségen alapul. A vezetés - a vezetők és a követők közötti kapcsolatra fókuszálva ennél szélesebb cselekvési pályát ír le, amelyhez nem szükséges egy formális pozíció betöltése vagy autoritás birtoklása. Leegyszerüsítve: a kérdés tétje ezen a ponton az, hogy az informális vezetők - mint Martin Luther King vagy Gandhi - tevékenysége értelmezhetö-e politikai vezetésként?

Ugyancsak fontos a vezetésről leválasztani az elit kifejezést is, amelyet a hétköznapi és tudományos diskurzusban gyakorta összemosnak vele (Zuba 2016). Ezzel kapcsolatban két fundamentális különbséget kell látni. Egyrészt, noha mindkét fogalom a politikai cselekvés egy kollektív formáját jelöli. Viszont amíg az elit egy kiemelt társadalmi és

\footnotetext{
${ }^{7}$ Fontos szem előtt tartani ezt az árnyalatnyi jelentésbéli különbséget, ugyanis az kihathat a vezetés társadalmilag konstruált koncepciójára. A vezér kifejezést a későbbiekben kizárólag a vezérdemokrácia keretében a karizmatikus vezető szinonimájaként fogom használni.
} 
politikai pozícióban lévő szereplők kizárólagosan horizontális kapcsolatát jelenti, addig a vezetés a vezetők és a követők közötti horizontális és vertikális kapcsolatát is jelölheti attól függően, hogy mit értünk pontosan a vezetők és követők „helyes” kapcsolódásán. Másrészt, amíg a vezetés pozitív, addig az elit negatív konnotációval rendelkezik (Blondel 2018; Zuba 2016). A vezetés esetében a vezetők és a követők közötti kapcsolat kétirányú és önkéntes. Ezzel szemben a hatalmi elit esetén mindig egy szervezett kisebbség gyakorol hatalmat a szervezetlen többség, a tömeg fölött. A fogalmi elválasztás tétje abban mutatkozik meg, hogy amennyiben az elit fogalmának alárendelődik a vezetés, azaz az elit fogalmilag meghatározza a vezetés tartalmát és irányát, akkor a vezetésről alkotott kép torzul: egyes elemek kihangsúlyozásra, míg mások kizárásra kerülnek. Ezért a kutatás során a kormányzás és az elit fogalmával nem foglalkozom, azokat a vezetésről fogalmilag leválasztva, és annak alárendelve használom.

\subsubsection{Harmadik előfeltevés: a fogalom konnotációja}

Mindezeken túl döntő fontosságú felismerni, hogy a vezetésnek van egy normatív jelentésrétege, amelyet nem lehet leválasztani róla. A fogalmi meghatározás, az elméleti keret elkerülhetetlenül meghatározza, hogy mit is lehet a jó vezetésről gondolni (Ciulla 2014b). Ez a vezetéskutatást domináló angolszász, főként az amerikai nyelvi kontextusban különösen szembetünő. Joanne B. Ciulla és Donelson Forsyth (2011, p. 230) nyomatékosan alá is húzzák: ,a vezető szónak az amerikai használata arra reflektál, hogy mit gondolnak az emberek egy adott helyen és időben arról, hogy milyennek kellene lenniük a vezetőknek (...) Így a „Mi a vezetés?” kérdése valójában azt takarja, hogy „Milyen a jó vezetés?” (ford. tőlem). Ellentétben akár az olasz (duce) vagy a német (Führer) nyelvvel, ahol egy negatív jelentéstartalom kapcsolódik a szóhoz, ebben a kontextusban a vezetés több az egyszerü leírásnál, az pozitív értékelés és dicséret. Pontosítva: az amerikaiak elismerik a bátor, erőskezü és akár autokratikus vezetőt, de csak akkor dolgoznának szívesen alatta, ha morális értelemben is el tudják őt fogadni.

Mit jelent ez pontosan? Ha azt mondja valaki, hogy egy bizonyos személy jó vezető, akkor két dolgot állít: ő morálisan és technikailag, azaz hatékonyságot illetően is jó. Ebből az következik, hogy a vezetés fogalma egyszerre magában rejti az etikusság (do the right thing) és a hatékonyság (get things done) igényét. A jó vezetés két aspektusa teljesen összemosódik (Ciulla 2018, pp. 446-49). Az etikus vezetéstől elvárható, hogy hatékony politikával elérje céljait, legyőzze (immorális) ellenfeleit. Mindazonáltal a 
hatékonyság sem bizonyul elégségesnek önmagában, ugyanis a követők számára meg kell indokolni a közös vállalkozást, a cselekvés módját, okát és várható következményeit. Ilyen értelemben a vezetök minden esetben jó vezetést ígérnek, amelynek hatékonynak és morálisnak is kell lennie egyszerre. Értelmezésem szerint a morális- és a hatékony vezetés közötti ellentét feloldódik abban, hogy a vezetők és a követők azoknak konkrét tartalmat adnak, pontosabban: azokkal szemben konkrét elvárásokat fogalmaznak meg. Ebből következően a vezetés fogalmához impliciten és elválaszthatatlanul kötődik az engedély (mit lehet megtenni), a kötelesség (mit kell megtenni) és a tiltás (mit nem lehet megtenni) mozzanata.

A vezetés fogalmilag minden esetben legitim cselekvésre és kapcsolatra utal, hiszen a követők „önkéntes” beleegyezésén nyugszik (önkéntesség kitétele). A vezetés szempontjából ez a mozzanat megkerülhetetlen. Ebből a tekintetböl különösen megvilágító E. D. Kort (2008) a szimfonikus zenekarok koncertmestereiről szóló példája. A koncertmestert formális pozíciója (headship) miatt követni fogják a zenészek annak ellenére is, hogy tudják, hogy az utasítások rosszak is lehetnek. Így a koncertmester - Kort értelmezésében - valójában csak ,állítólagos” vezető, ugyanis kizárólag a pozíciójából, a parancsból fakadóan tudja az elvárt követői cselekvést kikényszeríteni. Ellenben azok, akiket az állampolgárok, a potenciális követők egy csoportja választ meg arra, hogy vezessenek, kompetensnek és etikusnak kell tünniük. Másképpen fogalmazva: a követőknek szabadon kell dönteniük arról, hogy etikusnak és hatékonynak ítélik-e meg és követik-e a vezetőt. Ehelyütt lényegtelen, hogy az etikusság a követők, a többség akaratának teljesítéséből, vagy valamilyen abszolút értékből fakad, illetőleg, hogy a hatékonyság alatt a vezető saját ambícióit vagy épp követőinek a céljait realizálja. Ugyanis mindez a vezetők és a követők közötti egyedi kapcsolaton és igazodáson, alkalmazkodáson múlik.

A vezetés normatív korlátai az önkéntesség kitételében ragadhatók meg. Mind a hatékonyság, mind az etikusság szempontjából kritikus pont, hogy a követőknek szabadságukban áll - legalábbis formálisan - másképpen cselekedni, a kapcsolatot felbontani, azaz a vezetők hatékonyságát vagy etikusságát megkérdőjelezni. Ha erre nincs lehetőség, nemcsak a morális alap tünik el, hanem a hatékonyság sem értelmezhető, hiszen a kapcsolat fenntartása nem igényel személyes (politikai) teljesítményt és valódi követői elköteleződést. Ilyen értelemben a vezetők ugyan meg kívánják követőiket győzni a vezetés normatív tartalmáról, de mégis a vezetés azon múlik, hogy a követők elfogadják-e azt. Az ok könnyen belátható: követők nélkül nem 
lehet vezetőkről sem beszélni. Azaz: a vezetés minden esetben „plurális cselekvés” (Beerbohm 2015, p. 642; Kort 2008). Így abban a pillanatban, amikor a követés teljesen megszünik, azaz a követők nem tekintik már a vezetőt morálisnak és hatékonynak, akkor a vezetés véget ér, és annak hiánya (lack of leadership) róható fel.

Az inherens normatív tartalom abból a szempontból válik különösen fontossá, hogy a vezetés és a hatalom fogalma szorosan összekapcsolódik (Ciulla 2018; Kort 2008). ${ }^{8}$ A vezetést fogalmilag meg kell különböztetni az egyszerü, nyers hatalomgyakorlástól (ld. erről: Boda 2013; Burns 1978, pp. 9-28), amely az akarat keresztülvitelét, parancsolást, vagy az erőszak, a kényszer tiszta és kizárólagos alkalmazását jelenti. Itt a hatalommal nem rendelkező fél kizárólag passzív befogadó: vagy elfogadja a másik hatalmát és engedelmeskedik, vagy nem és vállalja annak következményeit. Könnyen beláthatónak tünik, hogy szükségszerü elválasztani a vezetést a puszta hatalommal való rendelkezéstől, hiszen ennek hiányában a vezetéselmélet egyszerü hatalomelméletté, a hatalommal rendelkezők ,,akaratátvitelének”, cselekvésének vizsgálatává válna.

Gondoljunk csak bele, hogy egy katonai parancsnok megrovásban részesíti azt, aki nem teljesíti a parancsot, még ha a parancsmegtagadás morálisan igazolható is lenne. Ilyenkor a „követők” véleménye a parancsról, utasításról és azok helyességéről teljesen irreleváns, hiszen attól függetlenül engedelmeskedniük kell. Egy totalitárius, autoriter rendszer kizárja azon személyeket a politikai cselekvésből, a politikai élet formálásából, akiktől nem várható el az engedelmesség vagy ellenállást tanúsítanak. Így intézményesített, legitim alternatívák nélkül az engedelmeskedőknek sincs más választásuk, mint hogy a hatalmat gyakorló akaratának eleget tegyenek. Ebben az esetben nem lehet vezetői teljesítményről beszélni: nem kell indokolni a cselekvést, nem szükséges meggyőzni a többséget a vezetés helyességéről.

Ennélfogva a vezetés elkerülhetetlenül nehezebb, körülményesebb az egyszerü hatalomgyakorlásnál, amely révén a vezető igazságát parancsosztogatás nyomán viszi keresztül, vagy épp az ügyintézésnél, amely már meglévő eszközökre, procedúrákra támaszkodva teljesíti a tőle elvártakat, azaz végrehajt. Ebben rejlik a „vezetés iróniája”

\footnotetext{
${ }^{8}$ A hatalom és a normatív jelentéstartalom konfliktusának kérdése áthatja a vezetéskutatás diskurzusát. A szakirodalom egy része amellett foglal állást, hogy a zsarnokok vagy az uralkodók nem tekinthetők „igazi” vezetőnek (Burns 1978; Heifetz 1994). Itt a kérdés valójában az, hogy mit is lehet kezdeni az ún. „Hitler problémával” (Ciulla 2018, pp. 442-44) vagy „Hitler szellemével” (Kellerman 2004, p. 11), amely körüllengi a vezetést. Pontosabban: azzal kell megküzdeni, hogy tekinthetö-e Hitler, és a hozzá hasonló „rossz” vezetők tevékenysége valódi vezetésnek. Az érem másik oldalát jelentik azon kutatói kísérletek, amelyek a „valódi” vagy ,igazi” vezetőket keresik, megkülönböztetve őket a „pszeudovezetőktől” (Bass és Steidlmeier 1999), az ügyintézőktől (a menedzserektől) (Bennis és Nanus 1985) vagy az ,állítólagos vezetőktől” (Kort 2008). Azonban ennek az elméleti vitának mélyebb tárgyalására itt nincs mód (ld. erről bővebben: Ciulla 2018).
} 
(irony of leadership) - állítja Keith Grint (2005b). A vezetésben nincsenek biztos pontok (igazságok vagy eszközök), ugyanis az minden esetben a vezetők és követök közötti esetleges és viszonylagos kapcsolaton nyugszik. A vezetés létrehozása és fenntartása állandó kihívás, legyen szó akár az általa nyújtott válaszokról, az elfogadott szerepekről vagy a cselekvés irányáról és tartalmáról. A vezető rákényszerül arra, hogy alkosson, azaz cselekvését indokolja és elfogadtassa. Így nem csoda, hogy a vezetői pozícióban lévők gyakran elkerülik a vezetést, s inkább parancsokat osztanak, vagy épp egyszerűen végrehajtják saját vagy mások döntéseit.

Mindazonáltal azt is látni kell, hogy a vezetés elválaszthatatlan a hatalomtól. Jean Blondel úgy fogalmaz, hogy a „[p]olitikai vezetés majdnem biztosan az egyik legmagasabb szintű és legáltalánosabb formája a hatalomnak” (ford. tőlem) (Blondel 1987, pp. 15-16). Nye még erősebben fogalmaz: “[h]a nincs hatalmad, nem vagy képes vezetni" (ford. tőlem) (2008, p. 27). A hatalom - a vezetés denotációjának fényében - a hatás kifejtésben mutatkozik meg. Blondel szerint a vezetés „...nyilvánvalóan és lényegében a hatalom megnyilvánulása (...) hiszen az magában foglalja azt a képességet, amellyel egyvalaki, vagy kevesek másokat olyan cselekvésre tudnak késztetni, amelyet máskülönben nem tennének meg” (ford. tőlem) (1987, p. 3). Andrew S. McFarland is hasonlóképpen érvel, mikor úgy definiálja a vezetést, mint egyfajta képességet, kapacitást olyan dolgok megvalósítására, amelyek máskülönben nem következtek volna be (1969, p. 155).

A vezetés ugyanakkor a hatalmat egy merőben más megvilágításba helyezi azzal, hogy a követőket nem téveszti szem elől. Burns a következőképp fogalmaz:

„Szükséges, hogy a hatalmat - és a vezetést - ne dolgokként (...) hanem kapcsolatokként értelmezzük. A hatalmat emberi motivációk és fizikai korlátok kontextusában kell elemeznünk. Ha meg tudjuk ragadni a hatalom ezen aspektusait, reménykedhetünk abban, hogy megértjük a vezetés igaz természetét" (ford. tőlem) (Burns 1978, p. 11)

A vezetés voltaképpen egy speciális formája a hatalomnak: egy olyan hatalmi kapcsolat (Burns 1978, p. 11; Nye 2008, pp. 25, 27), amelyben a követőknek hatalmukban áll ellenállni, s akár maguk is vezetést gyakorolhatnak és kezdeményezhetnek (Nye 2008, p. 34). Mivel a hatalmi kapcsolat a követők oldaláról szemlélve önkéntes, a vezetésben rejlö hatalom használata sem lehet öncélú vagy önkényes. A követők nem az utasításban rejlő parancs, kényszer és erőszak miatt engedelmeskednek, hanem azért, mert meg vannak győzve és győződve az utasítás tartalmának helyességéről. Ez azt feltételezi, 
hogy a vezetők és követők kapcsolata és szerepelosztása megfelelő (helyes) módon rendeződött. A vezetés és a hatalmi kapcsolat tehát állandó igazolásra szorul, amelynek pontos tartalmát a vezetők és a követők közötti interakciók alakítják ki. Összegezve: a vezetés normatív oldala a hatalom morálisan helyes (legitim) és hatékony használatára utal, amelynek gátja és mércéje a követők cselekvése.

A jelen gondolatmenet arra enged következtetni, hogy a vezetés normatív jellegéből fakadóan eredendően ,jó” és a vezetők és követők (hatalmi) kapcsolatának rendeződése az önkéntesség kitételéből következően „helyesnek” (helyénvalónak) kell lennie. Ennélfogva nem lehet - legalábbis tudományos értelemben ${ }^{9}$ - „rossz” vezetésről vagy épp a vezetők és követők ,helytelen” (illegitim) kapcsolatáról beszélni. A vezetés konceptuális ellentéte, annak hiánya vagy vége (lack of leadership). A vezetés végét jelenti az, ha a követök teljesen elpártolnak a vezetőtől, azaz a hatalmi kapcsolat megszakad, de a vezetés hiánya merül fel akkor is, ha az átalakulna nyers hatalomgyakorlássá, s így a vezetés helyét átveszi a parancs és a kényszer kizárólagos uralma. Ilyenformán a „jó” és a „helyes” jelző akár redundánsnak is tekinthető, mégis fontosnak tünik velük kiemelni azt a normatív jelentéstartalmat, amellyel végső soron a vezetők és a követők felruházzák.

\subsubsection{A vezetéskutatás csapdái}

A demokratikus vezetés bálványfogalomként különböző, akár ellentétes tartalommal is telítődhet. Ezért szükséges szembenézni azokkal a torzító körülményekkel, értelmezési csapdákkal, amelyek a demokrácia és a vezetés ellentmondásának feloldására vállalkozó kutatások esetében is megmutatkoztak, de valójában a vezetéskutatás egészét meghatározzák, attól függően mely területről közelítik meg a vezetés kérdését. Amíg a politikatudomány nézőpontjából a „hős”, hatalmi pozíciót betöltő vezető tevékenysége (A hös/nagy vezetö keresésének csapdája), addig a multidiszciplináris vezetéskutatás számára a lehető „legdemokratikusabb” vezetés (A vezetéstől való félelem csapdája) jelenti a fókuszt: az „,igazi” vezetést. Mindkét elöítélet lehatárolja, hogy a vezetés mely

\footnotetext{
9 A jó és rossz vezetés megkülönböztetése, s megítélése elkerülhetetlenül viszonylagos, az adott körülményektől függ. S bár az állampolgári és közírói szinten releváns lehet a jó és rossz vezetők megkülönböztetése, tudományos keretek között mégis értelmezhetetlen. Ha a vezetést nem egyszerü hatékonyságra fókuszáló technikának tekintik vagy épp bizonyos értékek mércéi szerint értelmezik, ahogy azt a kutatás teszi, akkor a (politika)tudós nem mondhatja meg, hogy mi számít „jó” vagy „,rossz” vezetésnek, csupán azt, hogy egy vezetés mikor ér véget, mikor ütközik korlátokba. A kérdés eldöntése tehát mindig az állampolgárok feladata, akik végeredményben a saját mércéjüket hozzák létre és alkalmazzák. Ennek kérdése később az 1.3.4. fejezetben a vezetéskutatás csapdái kapcsán is még előkerül.
} 
része, elemei, aspektusa kerül ki az elemzés keretéből, illetőleg milyen típusú és tartalmú vezetés tekinthető megfelelőnek.

A hös/nagy vezetö keresésének csapdája. A politikatudományi nézőpontot elsősorban az intézmény- és hatalom-centrikusság jellemzi. A politikatudomány - ellentétben a bevett és intézményesült szereplőkkel és intézményekkel - a politika amorf, dinamikusan változó dimenziójára kevésbé, vagy egyáltalán nem fordít figyelmet (Mannheim 1996, pp. 132-37; Schabert 2013, pp. 25-28). Ezért a politikai vezetés viselkedési aspektusát elhanyagolva, annak intézményi oldala kerül kihangsúlyozásra. A kutatások többsége a formális pozíciót betöltő vezetőkre és a politika kimeneteli oldalára tett hatásukra fókuszálnak (Blondel 1987, pp. 45-49; Elgie 2015, pp. 30-32; 137-70, ld. például: Elgie 2018). Ez azt is jelenti, hogy a vezetés politikatudományi megközelítését a „hatalom paradigmája” határozza meg, amely kizárólag a hatalom vagy a tekintély metszetében értelmezi a vezetés problémáját (Burns 1978, p. 11; Heifetz 1994, p. 1166; Tucker 1995, p. 4-27). Burns a következőképpen fogalmaz:

„[m]int politikatudós a »hatalom iskolájához« tartoztam, amely a személyek kölcsönös kapcsolatát kizárólag a hatalom alapján vizsgálta. (...) [Azonban a] politika hatalomként való értelmezése elvakított minket a hatalom politikában betöltött és a vezetés kulcsfontosságú szerepét illetően.” (ford. tőlem, kiemelés az eredetiben) (Burns 1978, p. 11)

Ez a torzítás kivetül arra is, hogy túl az elmúlt évek kézikönyvein (Elgie 2015; Foley 2013; Helms 2012b; Rhodes és 't Hart 2014) és intézményesülés irányába mutató fejleményein, a politikai vezetés továbbra is elhanyagolt és kevésbé intézményesült kutatási terület mind a politikatudomány egészéhez ${ }^{10}$, mind a multidiszciplináris vezetéskutatáshoz ${ }^{11}$ viszonyítva (Elgie 2015, pp. 19-22). Mindebből az tünik ki, hogy a

\footnotetext{
${ }^{10}$ A vezető nemzetközi politikatudományi társaságok közül csak az ECPR (European Consortium for Political Research) rendelkezik olyan állandó csoporttal, amely az elitek mellett a politikai vezetésre is fókuszál. 2015-ös alapításával szépen jelzi az elmúlt évek fejleményeit. Azonban az IPSA (International Political Science Association) a politikai elitekkel foglalkozó kutatási bizottsággal, és annak amerikai társa (American Political Science Association) a vezetés intézményi, formális felével foglalkozó szekcióval rendelkezik (Presidents and Executive Politics) (Elgie 2015, pp. 19-22). Ugyanakkor érdemes megemlíteni intézményesülési mérföldkövekként a 2000-ben a Harvard Egyetemen alapított „Public Leadership" központot és a 2016-ban életre hívott PUPOL (Public and Political Leadership) nemzetközi akadémiai hálózatát is. Érdekes adalék az is, hogy a politikatudományi kézikönyvekben a vezetés problematikája nem, vagy csak kis mértékben tünik fel. Michael Foley (2013, pp. 7-9) megvizsgálta a tíz legnépszerübb kézikönyvet, amelyből csak öt rendelkezett a vezetésre mutató indexelt referenciával. Azonban ezen kiadványok 1927 oldalából is csak 35 oldalon jelent meg a vezetés. Az is sokat elárul, mutat rá Foley, hogy az 52 szerzős, 1312 oldalt magában foglaló „The Oxford Handbook of Political Science" (Goodin 2011) c. kötetben egyetlen egy indexelt referenciát sem találunk a vezetökre vagy vezetésre vonatkozóan.

${ }^{11}$ Az üzleti szervezetek vezetésének kutatása sokkal egységesebb és koherensebb képet mutat (Burns 2003, p. 10; Elgie 2015, p. 19). A diszciplína ebben az irányban észrevehetően intézményesült, ahogy azt
} 
politikatudomány képviselői vagy leértékelik a vezetés szerepét és mellőzik kutatását, vagy annak intézményi, hatalmi oldalát emelik ki. S így ebből a szemszögböl csak a hatékony, formális pozíciót betöltő, nagy, s akár intézményi változást elérő vezető tevékenysége tünik igazán relevánsnak.

A vezetéstől való félelem csapdája. A multidiszciplináris vezetéskutatás ${ }^{12}$ nézőpontját egyfajta „félelem” egyre erőteljesebben határozza meg, ${ }^{13}$ amely a politikatudományi nézőponthoz képest sok tekintetben ellentétes következtetéseket eredményezett. Ez a „poszt-heroikus" fordulat (Bennis 1999; Brown 2014, 2016; Crevani, Packendorff, és Lindgren 2007; Fletcher 2004; Kellerman 2012; Komives és Dugan 2010; vö. Grint 2010) három mozzanatban érhető tetten.

- Az első a „demokratikus vezetés” állandó újrafogalmazása, ahogyan azt a szolgáló vezetés (Greenleaf 1977), a transzformatív vezetés (Burns 1978, 2003), az adaptív vezetés (Heifetz 1994), az autentikus vezetés (W. L. Gardner és mtsai. 2011) és a megosztott/szétosztott vezetés (Gronn 2002; C. L. Pearce és Conger 2003; Raelin 2011) koncepciója is teszi. Már nem a formális pozíciót betöltő, romantikus hős ideáját megtestesítő vezető van a középpontban, akinek cselekvése, követőkre gyakorolt hatása meghatározza a vezetés kimenetelét. Ebben a paradigmában a vezetés olyan relacionális, kollaboratív folyamat, gyakorlat, amelyen a résztvevők kölcsönösen osztoznak. Ez a kölcsönös függőségi viszony azt is jelenti, hogy a vezetés már nem feltétlenül top-down, hanem egyre inkább bottom-up folyamatként jelentkezik.

- A második mozzanat a követők szerepének kihangsúlyozása. Az ötvenes évektől kezdődően a vezetéskutatás fokozatosan egyre nagyobb figyelmet fordít a követők szerepére. A vezető és a követők közötti konceptuális határvonal elmosódik. A folyamat a követő-centrikus vezetéselméletekben (Meindl et al. 1985) és a vezetéselméletekkel konkuráló követéselméletekben (Kellerman

a kézikönyvek, tankönyvek növekvő száma is láttatja (például: Bass 2008; Northouse 2013). A Nemzetközi Vezetés Egyesület (International Leadership Association), a Richmondi Egyetem Jepson Vezetéskutatási Iskolája, valamint a Marylandi Egyetem Vezetés Akadémiája elsősorban az üzleti vezetés kutatására és oktatására fókuszálnak. A vezetéskutatás vezető akadémiai folyóirataiban (Leadership, Leadership Quarterly, Journal of Leadership and Organizational Studies és Journal of Leadership Studies) a politikai vezetés témája egyáltalán nem, vagy csak kevéssé kap figyelmet. A vezetéskutatás ezen irányát erősíti az alkalmazott vezetéskutatás és a ,jó vezetés” oktatásának, a vezetésfejlesztésnek a táguló piaca, amelyet Barbara Kellerman (2012) csak ,,vezetés-iparnak” (leaderhip industry) nevez.

${ }^{12}$ Ezen kutatások körébe tartoznak azon munkák is, amelyeknek van politikatudományi relevanciájuk, sőt ezek szerzői sok esetben akár politikatudósok (Burns, Kellerman) is, viszont kutatásaik szélesebb körben hatottak a vezetéskutatásban.

${ }^{13}$ Fontos megjegyezni, hogy a erősödő trend és normatív elvárás ellenére a vezetéskutatást továbbra is a transzformatív és karizmatikus vezetés vizsgálata határozza meg (Antonakis 2018, p. 58). 
2008; Uhl-Bien és mtsai. 2014) csúcsosodik ki, amelyekben már a követők számítanak meghatározó félnek.

- A harmadik mozzanat a vezetés árnyoldalának kiemelése. Egyre több szerző kérdőjelezi meg a nagy, karizmatikus vezetők szükségességét; és mutat rá tevékenységük morális veszélyeire, negatív következményeire, hatékonyságuk korlátaira (Kellerman 2004; Lipman-Blumen 2005; Tourish 2013; Dessewffy és Ságvári 2014).

Az erős vezetőktől való félelem és a demokráciával szembeni kívánalmak emelkedése a vezetéskutatókat egyaránt abba az irányba terelte, hogy a vezetés koncepcióját ezekhez az elvárásokhoz igazítsák, amely - némiképp sarkosan fogalmazva - magában rejti azt a önellentmondó gondolatot, hogy a vezetés egyáltalán nem is szükséges.

Összességében tehát: amíg a politikatudományi nézőpont csak a nagy, formális vezetőket értékeli, addig a vezetéskutatásban egyre erősebb az a tendencia, hogy a vezetés konstrukcióját a demokrácia egy ideájához igazítsák. Önmagában nem a megközelítések tartalmi oldala jelenti a problémát, hanem a nézőpontok kizárólagossága. Ennek fényében oly módon kell szembenézni a kutatás problémájával, hogy a kutató elkerülje mindkét csapdát. Ehhez a vezetés „nem esszencialista” és konstruktivista megközelítése megfelelő alapokat nyújt.

\subsection{A kutatás kérdései és menete}

A kutatás célja, tehát megérteni a demokratikus vezetést elméleti és gyakorlati szinten egyaránt. Ennek fényében a jelen vezetéselméleti kutatás arra a két összekapcsolódó kérdésre keresi a választ, hogy a demokratikus vezetés problémája miképpen oldható fel gondolati (elméleti) szinten és miképpen oldódik meg az a gyakorlatban. Ahhoz, hogy erre a két kérdésre egyszerre tudjon választ adni a kutatás, egy olyan megközelítésre van szükség, amely képes a demokratikus vezetés konstrukcióinak sokszínüségét kezelni és a demokratikus vezetés problémáját elméleti és gyakorlati szinten is vizsgálni. Ennek érdekében e két perspektívát magában foglaló konstruktivista metódust alakítok ki és fogok majd alkalmazni.

A probléma jellegéből fakadóan a kutató akkor jár el helyesen, ha a demokratikus vezetés problémáját elméleti és gyakorlati szinten is többféle perspektívából értelmezi. Ilyen értelemben a demokratikus vezetés problémája esetében nem a legjobb, hanem a lehetséges megoldásokat kell keresni, amelyek egyformán értékesek és érvényesek lehetnek. A kutatás számára a feladat tehát megérteni a vezetésnek a demokráciában 
betöltött lehetséges formatív és konstitutív szerepeit, a demokratikus vezetés konstrukciójának a lehetséges forrásait és folyamatát. Az egyszerü leíráson túllépve a demokratikus vezetés azon értékeire, ideáira koncentrálok, amelyek meghatározzák a társadalmi valóságot és az arról alkotott percepciókat.

Minderre lehetőséget ad a vezetés nem esszencialista, konstruktivista szemlélete ${ }^{14}$ (Barge és Fairhurst 2008; Elgie 2015, 78-107; Fairhurst és Grant 2010; Grint 2001, 2005b, 2014; Ospina és Sorenson 2006), amely nem feltételez rögzített és megváltoztathatatlan intézményeket, folyamatokat és elképzeléseket. Ebben a szemléletben a kutatások nem általános elméletet, univerzális fogalmi keretet kívánnak felállítani, de nem is az objektív ,igazságot” keresik. A vezetést egy társadalmilag konstruált jelenségként, egy performatív, kontextuális és attribúciós folyamatként írják le, amelyet a diskurzus és a cselekvés egyszerre formál (Barge és Fairhurst 2008, p. 232). A vezetés itt egyszerre szimbólum, tapasztalat, illetve társadalmi és történeti konstrukció, amelyet a vezetők és követők együttes jelentésadása hoz létre. A konstruktivizmus arra fókuszál, hogy miképpen ismerhető rá, ismerhető fel és ismerhető el az a jelenség, amit vezetésnek szokás hívni, vagy épp a politikai cselekvők miért tartják a vezetést fontosnak, illetőleg miért érvényesülnek bizonyos magyarázatok a vezetéssel kapcsolatban egy megadott helyen és időben jobban, míg más helyzetekben kevésbé.

Mindez viszont nem feltétlen jelenti az objektív valóság létezésének tagadását. Leegyszerüsítve a konstruktivizmus egyazon perspektívába helyezi az „objektív valóságot” és annak a „szubjektív értelmezését” azzal, hogy az ember és a világ közötti kölcsönhatás eredményeként írja le a „megértést”, a „tudást” és az „,igazságot” (Ospina és Sorenson 2006, p. 189). Lehetséges, hogy egy bizonyos cselekvés, mint folyamat, létrejön egy csoporton, közösségen belül, de az csak akkor tekinthető „,vezetésnek”, ha a résztvevő vezetők és követők és/vagy a megfigyelő kutatók explicit, vagy implicit módon akként értelmezik.

A kutatás két perspektíváját és menetét a konstruktivizmus ${ }^{15}$ két megközelítés módja adja. Gail Fairhurst és David Grant (2010, pp. 177-78) a vezetésre vonatkozó

\footnotetext{
${ }^{14}$ Természetesen nem diszkreditálható a vezetéskutatás más ontológiai és episztemológiai alapokokon nyugvó megközelítései (ld. erröl: Elgie 2015; Rhodes és 't Hart 2014) sem, mégis ebben az esetben, a probléma jellegénél fogva a konstruktivizmus keretében képes a kutatás érvényes állításokat megfogalmazni.

${ }^{15}$ Fontos azonban megjegyezni, hogy a konstrukcionizmust a konstruktivizmuson belülre helyezem. Magyarán: nem választom el a konstruktivizmust, amely a pszichológiai, szociálpszichológiai megközelítéseket fogja össze, a konstrukcionizmustól, amely elsősorban egy szociológiai kutatási irányt követi (Fairhurst és Grant 2010; Grint 2014, pp. 240-41).
} 
vizsgálódások tárgyát illetően megkülönböztette a társadalmi valóság konstrukcióját (construction of social reality) és a valóság társadalmi konstrukcióját (social construction of reality). ${ }^{16}$ Ezek mentén pontosítom a kiinduló kérdéseimet és a kutatás menetét (2. ábra).

- A társadalmi valóság konstrukciója keretében a kutatások a társadalmi interakciók kognitív termékére fókuszálnak, azaz: az egyén percepcióit helyezik előtérbe. Ebből a nézőpontból a vezetés konstrukciói, kategóriái és maga a jelentésadás folyamata válik igazán fontossá. A vizsgálat tárgya tehát maga a „vezetés jelentése” (meaning of leadership: Grint 2014, p. 242). A kutatás során itt arra a kérdésre keresem a választ, hogy milyen elméleti konstrukciók, „,implicit elmélet” keretében lehet a demokratikus vezetésröl gondolkodni. Ennek megfelelően a disszertáció első részében a demokratikus vezetés értelmezési lehetőségeit, azaz elméleti konstrukcióit vizsgálom. Először feltárom a három kiválasztott demokráciaelmélet - a deliberatív-részvételi -, az aggregatív-pluralista - és a vezérdemokrácia (Pakulski és Körösényi 2012) alappremisszáit a politika bemeneti és kimeneti oldalát és folyamatát illetően. Ezzel meghatározásra kerülnek a demokratikus politika elméleti keretei lehatárolva ezzel a vezetésről való gondolkodást. Másodszor a demokráciaelméletek premisszáiból kiindulva értelmezem a vezetés helyét és szerepét a ,jó” vezetés, valamint a vezetők és követők közötti „helyes” kapcsolat dilemmája mentén. Mindezzel a demokratikus vezetés egy-egy értelmezését, (,implicit vezetés elméletét”) alkotom meg, amelyek együttesen adják a demokratikus vezetés egy tipológiáját.

- A valóság társadalmi konstrukciója kapcsán a kutató a valóságot létrehozó interakciókat vizsgálja. A vezetés itt nem egy „gondolati termék”, hanem cselekvés. Azaz: a vezetés nem egyéni vagy a kutatás esetében elméleti konstrukció, hanem közös alkotó tevékenység. Így ehelyütt a vizsgálat tárgya már a ,jelentés vezetése” (leadership of meaning: Grint 2014, p. 242). A kutatás itt arra kérdez rá, hogy miként konstruálódik meg a demokratikus vezetés, pontosabban a vezetö miként tudja létrehozni a maga demokratikus valóságát. A dolgozat második részében a demokratikus vezetés gyakorlati konstrukcióira helyeződik az elemzés fókusza. A vezetés itt már nem gondolati (elméleti) konstrukció, hanem olyan komplex történet-elmesélési folyamat, amely

\footnotetext{
${ }^{16}$ Fairhurst és Grant (2010) a megkülönböztetést Bennett Pearcetől (1995) vették át.
} 
magában foglalja a vezető retorikai és performatív cselekvését is. A vezető történetében meghatározza saját demokratikus gyakorlatát és valóságát, amelyet öt elemzési sík - Keith Grint (2001, 2005b) nyomán az identitásépítés, a helyzetdefiniálás, a vízióalkotás, a taktikaalkotás és a követők mobilizálás mentén írok le. A történetek strukturálásával nem csak egységben kezelhető a retorikai teljesítmény és a performatív cselekvés, valamint a vezetők és a követők tevékenysége, de a különböző esetek összehasonlíthatóvá is válnak. Az előzetesen kialakított tipológia heurisztikai eszközként viszonyítási pontokat rajzol föl az empirikus vizsgálódás számára. Az elemzési síkok mentén feltárom azokat a jellemzőket az adott vezetés vonatkozásában, amelyek segítenek a tipológia szerint elhelyezni azokat. A strukturált elemzés előnye az is, hogy így értelmezhetővé válnak a típusok absztraktabb elemei és feltárhatók lesznek az esetek látensebb sajátosságai is.

A két perspektívát, mely átfogja a demokratikus vezetés elméleti és gyakorlati problémáját, a demokráciaelméletekből levezetett és a későbbiekben heurisztikai eszközként szolgáló vezetéstipológia kapcsolja össze.

\section{2. ábra: A disszertációkutatás menete}

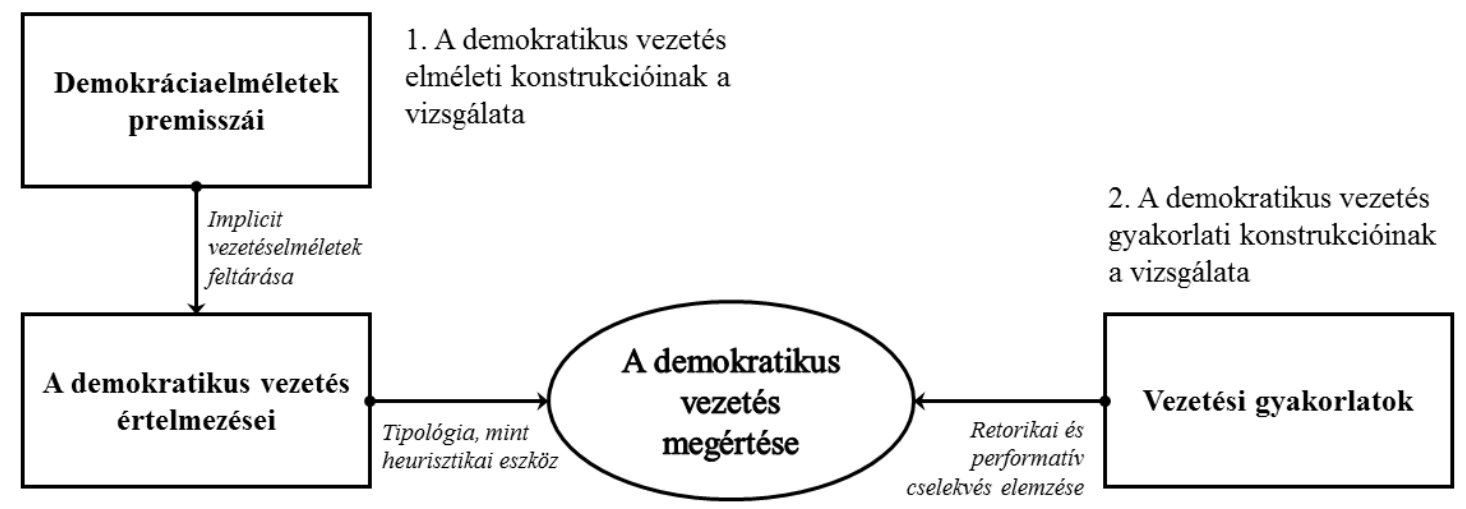

\subsubsection{A demokratikus vezetés elméleti konstrukciójának vizsgálata}

A kutatás első szakaszában a demokrácia- és vezetéselméletek összekapcsolásával arra vállalkozok, hogy meghatározzam a vezetés lehetséges elméleti (gondolati) konstrukcióit a demokráciában. A demokratikus vezetés egy tipológiáját kivánom felállitani, amely a későbbiekben, a kutatás második szakaszában heurisztikai eszközként fogja segíteni az empirikus elemzést.

Mivel a demokrácia ideája meghatározza vezetésről való gondolkodást (Ruscio 2008, pp. 4-6), joggal merül fel a kérdés, hogy a demokrácia mely elmélete is vehető alapul. Ahogy arra korábban rámutattam a demokrácia számos - akár több száz (Gagnon és 
mtsai. 2014) - egymásnak ellentmondó, egymást kizáró értelmezése létezik, amelyek különféle elvárásokat fogalmaznak meg, különbözőképp kezelik a demokratikus vezetés problémáját és eltérő megoldásokat nyújtanak a vezetés dilemmáira. Az egyszerüség kedvéért ezért kiinduló pontom itt Jan Pakulski és Körösényi András (2012) munkája lesz, amelyben megkülönböztetik a deliberatív-részvételi -, az aggregatív-pluralista és vezérdemokrácia elméletét. Könyvükben az első két demokráciaelméletet állítják szembe a weberi vezérdemokráciával rámutatva a vezető folyamatban betöltött meghatározó szerepére. S noha a politikaelmélet föárama valóban csak kis mértékben érinti a vezetés problematikáját expliciten (Kane és Patapan 2012, pp. 10-30; Ruscio 2008, p. ix), mégis arra lehet a kutató figyelmes, hogy a vezetés - bár merőben más formában - de a deliberatív-részvételi demokráciában (Barber, 1989, 2004: pp. 237-42; Gastil, 1994; Kuyper, 2012; Ruscio, 2008) és az aggregatív-pluralista demokráciában (Downs 1957, pp. 87-88, 1962, pp. 33-36; Keohane 2015; Olson 1971, pp. 174-78) is elengedhetetlen lehet (vö. Pakulski és Körösényi 2012). A demokráciaelméletek ezen felosztása több szempontból is gyümölcsöző a jelen kutatás szempontjából:

- Egyfelől a három demokráciaelmélet nem csak jól megfoghatóan különbözik a politikai folyamat szereplőire, irányára és tartalmára vonatkozó premisszákat illetően, de vélelmezhetően le is fedik a demokráciáról való gondolkodást azzal, hogy: amíg a deliberatív-részvételi demokrácia egy „morális” és az aggregatívpluralista elmélet egy „materiális”, addig a vezérdemokrácia egy tisztán „politikai” értelmezését adja a demokráciának. A deliberatív-részvételi demokrácia azt a normatív célt fogalmazza meg, hogy növelni kell az állampolgári kontrollt és az állampolgárok autonómiáját a politikában. Ellenben az aggregatív-pluralista demokrácia központi problémájaként már az merül fel, hogy miként lehet a preferenciákból kormányprogram vagy közpolitika, illetőleg miként lesz az érdekekből hatalom, hatalmi tényező úgy, hogy a demokratikus keretek ne sérüljenek. A vezérdemokrácia elmélete viszont a demokráciában már csak egy módszert lát a kormányzásra alkalmas vezetők kiválasztására.

- Másfelől a demokráciaelméletek eltérő pozíciójuk folyományaként más és más jellegű vezetést is igényelnek. Ezzel lefedik a demokratikus vezetésről való gondolkodást és a demokratikus vezetés problémájának fentebb bemutatott megoldásának stratégiáit. Hiszen amíg a deliberatív-részvételi demokrácia morális vezetés elvárását fogalmazza meg, illetve amíg az aggregatív-pluralista elméletek morális és hatékony vezetés egy bizonyos kombinációját írják elő, 
addig a vezérdemokrácia elsősorban a különösen hatékony (nagy hatást kifejtő) vezetésnek ad nagyobb teret.

$\mathrm{S}$ bár a vizsgált demokráciaelméletek leszükítése túlságosan leegyszerüsítőnek tűnhet, mégis együttesen átfogó képet alkotnak a demokráciáról és a vezetésről való gondolkodásról, beláthatóvá téve ezzel a lehetséges értelmezési alternatívákat. Annak érdekében, hogy a különböző absztrakciós szintekből fakadó problémát áthidaljam, a demokrácia elméletek premisszáit három pont - a politika bemeneti és kimeneti oldala, valamint folyamata - mentén rendezem majd.

Követve Wrent (2007) a vizsgálat során az ,implicit vezetéselméletek” módszerét alkalmazom, hogy a demokráciaelméletek vezetés konstrukcióit feltárjam. Wren (2007, 4) a vezetéskutatás egy szociálpszichológiai terminusát, az implicit vezetéselméletek módszerét ${ }^{17}$ adaptálja és alkalmazza történeti és elméleti kontextusban. Az implicit elméletek olyan „szürők”, amelyeken keresztül érzékelik és értelmezik a követők mások cselekvését. Ezek a szürők meghatározzák azt, hogy milyen ismérvek alapján nevezhető egy cselekvő vezetőnek vagy egy cselekvés vezetésnek. Az említett demokráciafelfogások esetében az implicit vezetéselméletek lencseként funkcionálnak majd, melyek a demokratikus vezetés problémáját kibontva meghatározzák milyennek is kell látni a ,jó” vezetést, illetőleg a vezetők és a követők közötti „,helyes” kapcsolatot és szerepelosztást. Minden elméleti keret a feltevések, a premisszák és az elvárások egyedi konstellációjával szolgálnak a demokratikus vezetéssel kapcsolatban.

Ily módon a három demokráciaelméletből három különböző vezetéstípus olvasható ki. A deliberatív-részvételi demokrácia kontextusa a Burns-féle transzformatív vezetés (Burns 1978, 2003) típusának kedvez, amely felhatalmazza a követőket és meghatározott morális alapelvek mentén demokratizálja a politika folyamatát. Az aggregatív-pluralista elméleti keretben Burns (1978) tranzaktív vezetés típusa teljesedhet ki, amely egy piaci cserére és alkudozásra, szelektív ösztönzőkre és kemény hatalmi eszközökre építve kívánja megoldani a kollektív problémákat. Ezekkel szemben a vezérdemokrácia már expliciten a weberi karizmatikus (M. Weber 1987, 1989, 2009) vezetés igényére apellál, amely a vezető erényei és alkalmassága révén képes megmenteni a politikai közösséget egy bizonytalan (krízis) helyzetben. Mindez nem egyszerű továbbgondolása a meglévő vezetéselméleti kategóriáknak, hanem egy átfogó vezetéstipológia levezetése a demokráciaelméletekből. Ilyen értelemben a típusok megnevezései - figyelembe véve a vezetéskutatás szakirodalmát - csak irányadók,

${ }^{17}$ Az implicit vezetéselméletekről bővebben: (Fairhurst és Grant 2010, p. 178; Fischbein és Lord 2004) 
azokat kibővített értelemben, a demokráciaelméletekből levezetett vezetés leírására használom. S mivel a vezetéstípusok szorosan követik az demokráciaelméletek logikáját teljesítve azok vezetéssel szemben támasztott elvárásait, semmiképpen sem felcserélhetők még ha azok átfedéseket is mutathatnak a gyakorlatban (például egy karizmatikus vezető tranzaktív vagy transzformatív vezetésre jellemző eszközöket használ).

Fontos kihangsúlyozni, hogy a disszertáció tézisének értelmében a vezetés a demokrácia gyakorlataként eltérő módon és minőségben, de minden demokráciaelméletben központi szerepet tölt be. A demokrácia különböző gyakorlatait vizsgálom, amelyek nem csak eltérő irányt, tartalmat (jó vezetés) és viszony rendszert (helyes kapcsolat) írnak elő, de eltérő módon is járulnak hozzá a demokratikus politika folyamatához. Mindegyik gondolatkísérlet a maga előnyeivel, hátrányaival önértékkel bír. S bár ezek a „valóság” csak egy szeletét jelenítik meg, mégis együttesen, tipológiaként lehetővé tehetik az események plurális olvasatát és egy átfogóbb kép kialakítását a politikai valóságról. Ebből a nézőpontból a különböző elméleti keretek olyan eszközök, amelyek segítik, hogy jelentéssel, értelemmel töltse fel a valóságot, értelmezze a tapasztalt világot. Másképpen fogalmazva: ezek az elméletek, elméleti konstrukciók olyan ideákat, modelleket és gondolatokat takarnak, amelyek az elemző számára segítséget nyújtanak a vezetés megértésében, az információ rendezésében és elemzésében. A kutatás ezen szakaszának fókusza nem önmagukban a demokráciaelméletek, hanem az azokból levezetett demokratikus gyakorlatok.

Természetesen a vezetéskutatás, s azon belül is a politikai vezetéskutatás irodalma széles körben támaszkodik a különféle vezetői, vezetési tipológiákra (ld. például: J. D. Barber 1972; Blondel 1987; Burns 1978; Downton 1973; Heifetz 1994; Nye 2008; Skowronek 1997). Ezek a tipológiák eltérő vezető típusokat, vezetési stílusokat vázolnak fel. Egyes tipológiák a vezetői környezetből (Blondel, Heifetz, Skowronek), míg mások a vezető személyéből (Barber) és cselekvéséből (Burns, Downton, Nye) indulnak ki. Általánosan igaz rájuk, hogy esszencialista módon adottnak veszik a vezetőt és/vagy a cselekvési környezetet. Bárhogyan is tegyenek, egy igen zárt gondolati keretet alkotnak, amelyben nem kapcsolódnak ahhoz a problémához, hogy a vezetők miképpen igazolják saját létüket a demokratikus keretek között. Ezzel szemben a disszertáció és az általa ajánlott tipológia elveti az esszencialista megközelítéseket. A kutatás szemszögéből a vezető, a vezetés vagy a vezetési környezet és a demokrácia 
sem esszenciálisan adott. Ilyen értelemben a vezetés és a demokrácia is állandó értelmezésre szorul.

Összegezve, a kutatás első szakaszában a demokratikus vezetés három elméleti konstrukcióját, típusát állítom fel. A kutatás az egyszerű leíráson túllépve a demokratikus vezetés azon értékeire, ideájára koncentrál, amelyek meghatározzák a társadalmi valóságot és az arról alkotott percepciókat. Ehhez először Wren (2007) kutatását követve egy analitikus sorvezetőt fogok kialakítani (2. fejezet), amely keretében megfogalmazott kérdések mentén az elemzést fogom folytatni a deliberatívrészvételi - (3. fejezet), az aggregatív-pluralista - (4. fejezet) és a vezérdemokrácia (5. fejezet) elméleti keretében.

\subsubsection{A demokratikus vezetés gyakorlati konstrukciójának vizsgálata}

A demokratikus vezetés természete nem érthető meg a vezetés valóságot megalkotó konkrét tevékenységének vizsgálata nélkül. Ezért a disszertáció második részében a demokratikus vezetés gyakorlati konstrukcióit elemzem és értelmezem a vezetéstipológia alapján. A vezetéstipológia azzal, hogy lehatárolja azt a mezőt, amelynek keretében a demokratikus vezetésről lehet gondolkodni, viszonyítási pontokat rajzol föl a politika valóságának megértéséhez. Fontos aláhúzni: a tipológia semmiképpen sem diszkrét keretrendszer, amelyben a vezetéstípusok élesen elkülöníthetők egymástól, hanem egy heurisztikai eszköz arra, hogy a demokráciában megvalósuló vezetési gyakorlatok megérthetővé váljanak. Egy-egy konkrét vezetés, vezetői gyakorlat úgy jön létre, hogy egyik vagy másik elméleti konstrukcióhoz fog közelebb kerülni.

Górcső alá veszem tehát egy-egy konkrét vezető demokratikus valóságot megalkotó tevékenységét. A demokratikus vezetés itt már nem gondolati termék, hanem jelentésalkotó tevékenység. A jelentésadás során a résztvevő vezetők és követők létrehozzák azt, amit demokratikus valóságként élnek meg. A vezetők aktívan formálják a környezet interpretációját, a célokat, a cselekvési stratégiát vagy épp a taktikát. Arról kívánják meggyőzni potenciális követőiket, hogy az ő értelmezésük és cselekvésük a helyénvaló és így az jelenti az ,igazságot” és a „valóságot”. A megalkotott politikai valóságot nem lehet egyszerűen retorikai teljesítményként értékelni. Howard Gardner (2011) a vezetést olyan komplex történet-elmesélési folyamatként írja le, amelyet a vezető szavakkal és személyes példamutatással alkot meg. A vezető nem egyszerüen átadja a történetet a nagyközönségnek, hanem meg is testesíti azt. A vezető retorikájával 
(wordcraft) és performatív cselekvésével (stagecraft) (Uhr 2014) egyszerre teremti és formálja meg a valóságot.

A vezető számára a képzelt „,valóság” korlátját a közönség valóság-, vagy esetünkben demokráciaképe jelenti. Keith Grint (2005b) rámutatott, hogy a politikai valóság kialakításában a „tények”, az ,igazság” nem mindig jelentenek korlátokat. Például a második öbölháború igazolása szempontjából a vezetés számára lényegtelen volt, hogy Irak valóban birtokol-e tömegpusztító fegyvereket vagy sem, sőt mint utólag kiderült nem is találtak ilyen jellegű fegyvereket. A kérdés az volt, hogy sikerül-e ezzel meggyőzni másokat a háború jogosságáról. Ebben az értelemben az állampolgárok tapasztalatai és a vezetök történetei között egyfajta dinamikus kapcsolat alkotja meg a politikai valóságot. A vezetőnek így nem csak párhuzamba kell állítania retorikáját és cselekvését (,azt teszem, mutatom, amit mondok”), de össze is kell hangolnia a vezetői történetét a követők igényeivel és elvárásaival (,,azt mondom, teszem és mutatom, amiről úgy gondolom, hogy mások pozitívan értékelhetnek”). Természetesen az állampolgárok egy-egy vezetői történetet jobban, míg másokat kevésbé támogatnak. Gardner a vezetők történetei között darwini versenyt feltételez, amelyek a közvélemény támogatásáért küzdenek. Az a narratíva, amely jobban egybeesik az állampolgárok tapasztalataival, elképzeléseivel, előnybe kerül a versenytársaival szemben (H. Gardner 2011, pp. 14-15).

Fontos aláhúzni: a kutatásnak nem célja megítélni azt, hogy egy vezető vagy vezetés demokratikus-e vagy sem, csak azt feltárni, hogy egy konkrét esetben a vezető miként igazolja és fogadtatja el döntéseit és cselekvését, azaz győzi meg követőit azok helyességéről a demokratikus vezetéstípusok fényében. A kérdés itt tehát az, hogy a vezető az általa megfogalmazott és cselekvésével megtestesített történettel melyik vezetési típushoz közelít vagy kíván közelíteni. Az esszencialista tipológiákkal szemben, melyek racionális kapcsolatot feltételeznek a konkrét vezetők és azok (objektív) politikai kontextusa között, a kutatás itt azt ajánlja, hogy a vezetés típusa attól függ, milyen módon, milyen tartalommal győzi meg közönségét hatékonyságáról, helyességéről és legitimitásáról.

A vezetés gyakorlatának feltárásához és leírásához Grint (2001, 2005b) által alkalmazott elemzési síkokat fogom használni. Grint értelmezésében a vezetésnek öt kérdésre kell választ adnia: Kik vagyunk? Hol vagyunk? Mit szeretnénk elérni? Hogyan szeretnénk elérni? Miért kívánják a követők mindezt elfogadni? Mindebből öt elemzési 
sík rajzolódik ki: az identitásépítés, a helyzetdefiniálás, a vízióalkotás, a taktikaalkotás és a követők mobilizálása.

Ezen öt aspektus mentén strukturált elemzés három módon járul hozzá a kutatás egészéhez. Egyrészt összefogja a vezetés retorikai (wordcraft) és a performatív (stagecraft) teljesítményét, amely együttesen adják a vezetés gyakorlatát. Másrészt az elemzés egyaránt bevonja a vezetőt és a mobilizálás nyomán a követőket is az elemzésbe. Ezzel egyfelől egy átfogó kép alakítható ki a vezetésről szem elől nem tévesztve a fogalom denotációjában gyökeret verő elemeit. Másfelől így a vezetői történet elmesélés nem kerül névértéken való elfogadásra, hiszen visszacsatolásként a vezetés értékelését a mobilizálás hatásosságához mérten a követők végzik el. A vezető szavaiban és tetteiben esetlegesen felmerülő különbségek csak annyiban relevánsak, amennyiben azok a követők viszonyulásában értelmet nyernek. Leegyszerüsítve: itt a kérdés az, hogy a követők hitelesnek tartják-e a vezetőt az általa kialakított vezetéskép fényében vagy sem. Harmadrészt a történetek átlátható módon történő rendezésével lehetővé válik a vezetéstípusok elemeinek kiemelése, a tipológiába való elhelyezés és a vezetők összehasonlítása. Pontosabban fogalmazva: a vezetés minden gyakorlati konstrukciójából kiolvasható valamilyen válasz a fentebb megfogalmazott öt kérdésre, amelyből kikövetkeztethetők vagy leszürhetők a vezetéstípusokra jellemző elemek és vonások. Sőt az elemzési síkok mentén feltárhatók a vezetéstípusok absztraktabb elemei és az eset látensebb jellegzetességei is.

A vizsgálat megkezdése előtt (7. fejezet) tisztázom, hogy a grinti elemzési síkok a vezetéstípusok mely szempontjára és elemére mutathatnak rá összekötve ezzel a disszertációkutatás elméleti és az empirikus szakaszát. Ezt követően konkretizálom az empirikus elemzés menetét és az alkalmazott elemzési módszereket is. Ezt követően két összehasonlító esettanulmány keretében kerül bemutatásra, hogy egy-egy vezetés miképpen hozhatja létre saját demokratikus valóságát. Az első tanulmányban (8. fejezet) összehasonlítom Orbán Viktor magyar miniszterelnök és Angela Merkel német kancellár vezetését a migrációs válsággal kapcsolatban. A második tanulmányban ( 9 . fejezet) Theresa May konzervatív miniszterelnök és James Corbyn munkáspárti politikus vezetését elemezem a Brexit kérdését középpontjába állító 2017-es brit parlamenti választások kapcsán.

Az esetválasztást két körülmény magyarázza. Egyfelől olyan események köré szerveződnek, amelyeket egyes elemzők és kommentátorok a demokrácia kihívásaként értelmeznek, míg mások a demokrácia egyfajta beteljesüléseként írnak le. Általánosan 
ez a bizonytalanság látványosan kihangsúlyozza és kontrasztosabbá teszi a demokratikus vezetésben rejlő problematikát, amelyet a rutinjellegü politikai üzemmód és cselekvés könnyen elfedhet. Másfelöl az összehasonlítani kívánt vezetők tevékenysége és vezetésértelmezésük igen különböző képet láttatnak, amely segít őket az egyik vagy másik viszonyítási ponthoz közelítve elhelyezni és értelmezni.

\subsection{A kutatás céljai és korlátai}

A disszertáció kapcsolódni kíván a kritikai vezetéskutatás agendájához (Collinson 2014; Collinson és Grint 2005), amely a politikai vezetés változó természetére kíván rámutatni, előhívva és újragondolva a vezetéskutatás alapvető dilemmáit és ellentmondásait. A kutatás megközelítésének alapját a tézise adja, miszerint a vezetés és a demokrácia fogalma nem csak, hogy nem mondanak ellent egymásnak, de még függenek is egymástól. Sőt, gyakorlatot tekintve a politikai vezetés formatív és konstitutív módon járul hozzá a demokráciáról alkotott képhez. Ily módon fel kívánom oldani a demokratikus vezetés problémáját elméleti és gyakorlati szinten egyaránt. A vállalkozás tétje épp abban a felismerésben érhető tetten, hogy a problémának nem csak elméleti, de gyakorlati relevanciája is szembetünő.

A kutatás célja egy a demokratikus vezetésre fókuszáló tipológia felállítása és alkalmazása egy két perspektívát magában foglaló konstruktivista megközelítésben. A tipológia elméleti szinten különböző nézőpontokat foglal magában, amelyek önmagukban is ugyan helyesek lehetnek és koherens világot alkothatnak, mégis csak együtt képesek teljes képet adni a politikai valóságról. Empirikus szinten a tipológia a megvalósuló vezetési gyakorlatok és események plurális olvasatát és értelmezését teszi lehetővé, amellyel elkerülhető a vezetés bizonyos elméleti szempontból releváns elemeinek diszkreditálását és delegitimálását. A plurális olvasat átlátható módon kezeli saját elméleti előfeltevéseit, azok hatását a vezetésről alkotott tudásra, valamint az „eredmények” interpretálását.

Összességében a vállalkozás újszerü és hiánypótló jellege a demokratikus vezetés problémájának feloldásának irányában és módjában mutatkozik meg, pontosabban: a szakirodalomban megjelenő megoldási stratégiákat meghaladó tézisében, a kétirányú az elméleti és gyakorlati szintet egyszerre átölelő konstruktivista megközelítésében és a kérdés plurális olvasatát lehetővé tevő tipológiában.

Mindazonáltal a kutatásnak számolnia kell saját korlátaival is: 
- Egyfelöl számításba kell venni azt, hogy a három elmélet keretében, ahogy a demokráciának, úgy a vezetésnek is számos olvasata lehetséges, melyek közül csak egyet fog a kutatás reprezentálni. Ez azt is jelenti, hogy a szerteágazó demokráciaelméletek és vezetéselméletek elkerülhetetlenné tesznek bizonyos mértékü leegyszerüsítést. Ugyanakkor ez indokoltnak tünik annak fényében, hogy a kutatás első szakaszának célja a demokratikus vezetés három kontrasztos értelmezésének a feltárása.

- Másfelől meg kell jegyezni, hogy az empirikus esetek célja nem az elméleti értelmezések igazságtartalmának igazolása, hanem az analitikus keret hasznosságának illusztrálása. Mivel a kutatás nem kíván egy-egy demokrácia- és vezetéskonstrukció mellett, vagy az ellen érvelni, az esettanulmányok illusztratív jellegüek és a demokratikus vezetés egy-egy gyakorlati értelmezését jelentik. Reményeim szerint az elemzési keret mélyíti az adott eset megértését, amely végső soron a kutatás ezen szakaszának a célja. 


\title{
ELSŐ RÉSZ:
}

\section{A DEMOKRATIKUS VEZETÉS ELMÉLETI KONSTRUKCIÓI}

\author{
„Az elméletek eszközökké váltak - s nem \\ válaszokká a talányokhoz, amelyekre \\ támaszkodhatunk"
}

William James (1907, p. 53) (ford. tőlem) 


\section{2.}

\section{AZ ANALITIKAI SORVEZETŐ}

A bevezető fejezetben azt az állítást fogalmaztam meg, hogy az érvényesíteni kívánt demokrácia ideája meghatározza, hogy miként lehet a demokratikus vezetésröl gondolkodni. Ennek fényében a demokratikus vezetés értelmezése során akkor járhat el a kutató helyesen és körültekintően, ha a kérdést több nézőpontból is megközelíti. Ez azt jelenti, hogy a demokratikus vezetés problémájának a plurális olvasatát lehetővé tevő tipológiára van szükség. Ehhez átlátható és követhető módon kell feltárni, illetve összehasonlítani a demokratikus vezetés elméleti konstrukcióit. Követve Wren (2007, pp. 4-9) gyakorlatát egy analitikai sorvezetőt rajzolok fel. Annak érdekében, hogy analitikai értelmet nyerjen a számtalan forrás, melyre a kutatás épül, egy elemzési protokollt határozok meg, hogy elkülönítsem és beazonosítsam az elméletek alappremisszáit és feltételezéseit a demokratikus politikát és a vezetést illetően. Az analitikai sorvezető haszna abban rejlik, hogy felfedi a nem explicit módon megfogalmazott elemeit a vezetésnek és letisztázza az elméletek közötti különbségeket.

\subsection{A demokrácia konstrukciója}

A demokráciát széles értelemben olyan rendszerként definiáltam, amelyben a kormányzók és kormányzottak kapcsolata egyedi módon szerveződik meg (SchmitterKarl 1991, pp. 76-77). A demokráciáról, mint folyamatról, rugalmasságot és lezáratlanságot szokás feltételezni, amely nem rendelkezik megszilárdult formákkal: biztos kiinduló állapottal, vagy konkrét végkifejlettel. Az elemzés szintjén mégis érdemesnek tünik a demokrácia müködését három ponton „kimerevíteni” annak érdekében, hogy megragadhatóvá váljon az adott konstrukció belső logikája és igazolása.

- Az első pont: a politika bemeneti oldala. Itt számolni kell a demokrácia megkülönböztetett elemeivel, mint az állampolgárok és a részvétel szerepével. Az elméletek komoly különbségeket láttatnak abban, hogy eltérően értelmezik az állampolgárok politikai teljesítőképességét, kapacitását és preferenciáik természetét. A kutatás fókusza ezen a ponton kettős. Egyfelől fontos látni a preferenciák eredetét, pontosabban azt, hogy azok a politikai folyamat viszonylatában eleve adottak-e (ex-ante), vagy annak folyományaként 
változhatnak (ex-post). Másfelől tisztázni kell, hogy az állampolgárok mennyire közérdek- vagy önérdek-orientáltak, racionálisak, kompetensek és informáltak. Ennek fényében különösen kritikus pont a politikai részvétel, amelyre ugyan minden esetben a folyamat katalizátoraként szokás tekinteni, de kérdéses, hogy az mindenki számára nyitott-e, vagy csak kevesek kiváltsága. A politika bemeneti oldalán a fó kérdés az, hogy ki a politikai cselekvés alanya és mi indítja be a politikai folyamatot.

- A második pont: az ideális politikai folyamat. Ezt illetően egyrészt világosan kell látni azt, hogy a folyamat a kormányzók és kormányzottak viszonylatában milyen irányt ír le, pontosabban fogalmazva azt: hogy a folyamat alulról felfelé (bottomup) vagy fentröl lefelé (top-down) halad-e. Másrészt meg kell határozni, hogy a folyamat miképpen kapcsolódik az állampolgári preferenciákhoz. Összegezve: a folyamat vizsgálata során arra vagyok kíváncsi, hogy az adott elmélet hogyan köti össze a politika alanyait annak folyamatával.

- Harmadik pontként számításba kell venni a folyamat kimenetelét is. Az elméleteknek végül választ kell adniuk arra, hogy milyen eredményt várnak el a politika folyamatától. Itt nem lehet megkerülni a szavazás szerepének a tisztázását sem. Ehelyütt a kérdés - némiképp leegyszerüsítve - az, hogy a politika miért is zajlik, azaz: mi a demokratikus politika célja.

Fontos leszögezni, hogy nem szándékozom itt az egyes demokráciaelméletek kritikájával és gyengeségeikkel vagy empirikus érvényességükkel foglalkozni. S bár egyes elméleti keretek „utópisztikusabbnak” tünnek vetélytársaiknál, mégis belátható, hogy mindegyik egy „elképzelt világot” alkot a demokratikus politikáról. Az elemzésemet az a kérdés mozgatja, hogy az elméleti keretek miként írják le a demokratikus politikát. A célom tehát a lehető leghitelesebben meghatározni az elméletek demokráciára vonatkozó premisszáit, igazolási kísérleteiket annak érdekében, hogy később a legteljesebb módon feltárhassam az implicit vezetéselméleteiket.

\subsection{A vezetés konstrukciója}

Az implicit vezetéselméletek felállítása során a vezetéskutatás két klasszikus dilemmájára fókuszálok, amelyek feloldását a demokratikus vezetés önigazolásigényének kielégítésével azonosítottam. Az első dilemma értelmében dönteni kell arról, hogy a vezetéssel szemben hatékonyságbéli vagy inkább etikai elvárások kerülnek-e érvényesítésre. Ez semmiképpen sem egy egyszerüen megválaszolható 
kérdés különösen annak fényében, hogy amellett foglalt állást a kutatás, hogy a vezetés koncepciójának - inherens normatív tartalmából következően - rendelkeznie kell mind a hatékonyság, mind az etikusság egy bizonyos formájával, szintjével. Ebből következően a valódi dilemma az, hogy a hatékonyságbéli és morális elvárásokat miképpen lehet kibékíteni, vagy másképpen fogalmazva milyen elegyük képzelhető el? Ezt a következő kérdések mentén konkretizálom:

- Milyen kihívások elé állitják a vezetést? Milyen célokat tüznek ki elé? (1. szempont) A vezetés célját és irányát illető követői, állampolgári elvárások meghatározzák azok normatív tartalmát. Amennyiben a vezetőtől azt várják el, hogy a közösség létét fenyegető válságot hárítsa el, akkor a bizonyos etikai elvárások mellett fontosabb szempontnak tünik a hatékonyság kérdése. Egy másik végletben gondolkodva: amennyiben a vezetőt valamilyen morális problémával állítják szembe, vagy éppen valamilyen morális fejlődést kívánnak elérni általa, akkor megítélése szempontjából sokkal fontosabbnak tünik bizonyos alapelveknek, értékeknek való megfelelés, s így az megelőzheti és felülírhatja a hatékonyságot illető elvárásokat. A kép világos, de korántsem fekete-fehér. A probléma nem mérlegelés, hanem igazolás kérdése. A megfogalmazott kihívások meghatározzák és kontextusba helyezik, hogy mi számíthat morálisan helyes és hatékony döntésnek, cselekedetnek és eszköznek. S bár nem lehet általánosan megmondani, hogy mely cél mely eszközt szentesíti majd, mégis joggal feltételezhető közöttük a szoros összefüggés, a szubsztantív kapcsolat.

- Milyen politikai tudást igényel a célok elérése és a megfelelö eszközök kiválasztása? (2. szempont) A célok, kihívások kijelölése mellett nem a konkrét eszközök mibenléte az igazán érdekes, hanem a vezetéshez szükséges politikai tudás. Pontosabban fogalmazva: a kérdés az, hogy milyen tudás szükségeltetik ahhoz, hogy a vezető felismerje és elérje a kitüzött célokat, valamint ahhoz megfelelő eszközöket tudjon rendelni. Fontosabb tehát, hogy a vezető képes legyen a megfelelő eszköztárat kiválasztani, mint hogy az tételesen mit is takar. $\mathrm{E}$ mögött az a gondolat húzódik meg, hogy a jó vezetés szempontjából lényegtelen, hogy a vezetök milyen eszközöket használnak, ha azokat a megfelelö cél szolgálatába állítják, illetőleg, ha azokat „erényesen”, azaz megfelelő politikai tudás segítségével használják. Az állampolgári elvárás egyértelmü: a vezető tudja, hogy mit csinál, és mit kell csinálnia. Így a tudás típusa meghatározza azt, hogy miként lehet érvényesülni a demokratikus politikában, miképpen szelektálódnak 
ki, rekrutálódnak a vezetők, illetőleg azt is, hogy mit is takar pontosan: „kompetensnek” lenni a politikában.

A különböző demokráciaelméletek eltérő eszközöket szabnak meg a vezetők számára, amelyek között válogatva a vezetéshez szükséges tudás más és más típusa kerül előtérbe. Az elemzéshez Arisztotelész hármas tudás felosztását ${ }^{18}$ (Körösényi 2005, pp. 24-32; 232-34) hívom segítségül, amelyben univerzális elméleti (ideológiai vagy filozófiai) - (episztémé), technikai és produktív (tekhné), valamint gyakorlati tudást vagy „cselekvőképességet” (praxisz) különböztet meg. Az episztémé valamilyen univerzális igazság birtoklását jelöli és egyfajta értékracionális tevékenységet (M. Weber 1987, pp. 53-54) - úgy mint az igazság vagy más abszolút érték keresését és közvetítését - ír le. Ebből a nézőpontból a politikai cselekvés a weberi érzületetika (M. Weber 1989, p. 75) azaz a tárgyát képző értékek - mentén kerül megítélésre. A techné viszont már egy mesterségre és célracionális tevékenységre (M. Weber 1987, pp. 53-54) mutat rá, amelyben a politikai vezető valamilyen rajta kívül álló dolog létrehozását és megalkotását célozza meg. Ebben az értelemben a mesterembernek felelősséget kell vállalnia alkotásáért, amely vagy betölti rendeltetését vagy nem. Így a vezető tevékenysége a weberi felelösségetika (M. Weber 1989, pp. 74-75) alapján kerülhet megítélésre. Ezzel szemben a praxisz az önálló cselekvésre és döntésre való képességet jelöli. Ennek fényében a vezetőnek saját magának kell meghatároznia a tevékenysége belső logikáját (érték és/vagy célracionalitást) és annak megítélésének dimenzióját (érzület- és/vagy felelösségetikát).

A politikai vezetéshez természetesen szükség lehet a tudás mindegyik formájára, de fontos látni, hogy egyes vezetésértelmezésekben a politikai tudás egy bizonyos típusa fontosabbnak és kritikusabbnak tünhet, mint a többiben. Ez a gyakorlatban annyit tesz, hogy bár a vezető pótolhatja és kiegészítheti politikai tudását például megfelelő tanácsadókkal (Machiavelli 2015, pp. 119-20) -, de nem kerülheti meg azt a követői elvárást, hogy egy meghatározott politikai tudás birtokosának tünjön fel.

A másik dilemma arra irányul, hogy a vezetőknek, vagy a követőknek tulajdonítható-e nagyobb szerep a kapcsolatukat és a folyamat kimenetelét illetően. A kérdés a vezetés fogalmának kerete, denotációja és normatív konnotációja, valamint a demokráciában

${ }^{18}$ Lásd három tudásfajtáról részletesebben Arisztotelész „Metafizika” (1992, 1025b-1026a), „Politika” (1984, VII. 9.) és „Nikomakhoszi etika” (1987, 1139b-1142b) címü munkáját. 
kiemelt szerepet betöltő, a politikai döntések hatásait magukon viselő állampolgárok szemszögéből is fontos. Három kérdésben konkretizálom a dilemmát:

- Miképpen értelmezhető a vezetök és a követők hatalmi viszonya? (3. szempont) A vezetést bár elválasztottam az egyszerü, nyers hatalomgyakorlástól, mégis a hatalomtól fogalmilag nem lehetett elkülöníteni. A vezetők és a követők közötti viszonyt egy hatalmi kapcsolatként fogtam meg. Látni kell, hogy ebben a viszonyban nem mellékes, hogy a hatalom mely aspektusát ${ }^{19}$ emelik ki az elméletek: a hatalom közös alkalmazását (power with), vagy annak mások feletti gyakorlását (power over), vagy azt a képességet, amely valaminek a megtételéhez szükséges (power to). A hatalom közös létrehozása és alkalmazása egyfajta egyenlőségre alapozott kollektív hatalomgyakorlást és cselekvőképességet hangsúlyoz, amelyet valamilyen követőkre irányuló felhatalmazás (empowerment) és emancipáció előz meg. A hatalom mások feletti gyakorlása esetében már a hangsúly a vezetők hatalmi pozícióján és dominanciáján van, amellyel mások cselekvését befolyásolhatják a kitüzött célok eléréséért. Mindezzel szemben a hatalom egyéni cselekvőképességre rámutató aspektusa a vezető cselekvési és alkotó szabadságát emeli ki, amely a követők általi felhatalmazáson (authorization) nyugszik.

- Milyen pályát írnak le a vezetők és a követők közötti interakciók? (4. szempont) A vezetők és a követők kapcsolatát és a vezetés folyamatát interakciók határozzák meg. A klasszikus megközelítés szerint ezek az interakciók vertikális ívet írnak le, azaz egyfajta alá- és fölérendeltséget feltételeznek. Ez a hierarchikus viszony azonban érdekalapú - vagy érzelmi kapcsolódást is jelenthet. Emellett a vezetéskutatásban egyre erősebb az az elvárás, hogy a kommunikáció horizontális pályát rajzoljon fel. Az ilyen jellegü kapcsolatok minden esetben valamilyen értéken - például egyenlőségen, társadalmi igazságosságon és politikai részvételen - alapulnak. Azaz: ezek a modellek elképzelhetőnek és kívánatosnak tartják a szereplők egymás mellé rendelését.

- Milyen szerepet kapnak a vezetők és a követők a vezetés folyamatában? (5. szempont) A tárgyalt viszonyrendszert illetően ugyancsak meghatározó, hogy milyen szerepet osztanak a vezetőknek és a követőknek. Melyik fél dominálja a kapcsolatot? Melyik féltől várják (el) a kezdeményezést? Melyik félre helyezik

\footnotetext{
19 A hatalom ezen aspektusainak analitikus elválasztásáról egyre szélesebb körben folyik elméleti diskurzus (Battegazzorre 2017; Morriss 2012; Pansardi 2011a, 2011b, 2012a, 2012b), amelyre ehelyütt nincs módom kitérni.
} 
ebből a szempontból a nagyobb felelősséget? Gondoljunk csak bele: ha például széles állampolgári részvételt írunk elö, akkor a követők részéröl is nagyobb aktivitást várunk el. Ha viszont kizárólag a vezetők kezébe helyezzük a közösség problémáinak a megoldását, akkor a követőknek is kisebb szerepet kell tulajdonítanunk. Azt kell tehát meghatározni, hogy a vezetők és a követők proaktív vagy reaktív, netán kölcsönösen aktív, azaz koaktív félnek tekinthetök-e.

A két elméleti dilemmát tehát öt kérdésre bontottam. Megválaszolásuk azt a feltételezést vonja maga után, hogy rendelkezésre állnak elképzelések azt illetően, hogy miben áll a demokrácia „lényege” vagy „természete”. Az elkövetkező fejezetekben úgy járok el, hogy a kérdésekre adható válaszokat a deliberatív-részvételi-; az aggregatív-pluralistaés a vezérdemokrácia elméleti elvárásai függvényében dolgozom ki, így megfogalmazva az implicit vezetéselméletüket. 


\section{3. VEZETÉS A DELIBERATÍV-RÉSZVÉTELI DEMOKRÁCIÁBAN}

Az antik demokrácia ideájára építkező deliberatív-részvételi demokrácia keretei között lehet talán a legnehezebben elképzelni a vezetést. Ez azonban nem feltétlenül van így és erre egy fiktív példa világít rá tökéletesen.

Idézzük fel az 1957-es „Tizenkét dühös ember” címü filmet, amelyet a demokrácia e felfogásának egyfajta leképezésének szoktak tekinteni (Babcock és Sassoubre 2007). Ennek a bírósági drámának a középpontjában 12 esküdt áll, akiknek feladatuk ítéletet hozni egy gyilkossági ügyben. Dönteniük kell élet és halál kérdéséröl: arról, hogy az apja meggyilkolásával vádolt fiú ártatlan vagy bünös. A cselekmény a film elején elhangzott záróbeszédek kivételével végig az esküdtszéki szobában játszódik, ahol az esküdtek vitatkoznak, érvelnek, és végül megegyezésre jutnak. A történet igen fontos eleme, hogy a szereplők nevére nem derül fény a film folyamán. ${ }^{20} \mathrm{~A}$ cselekmény fókuszában az igazság keresése áll, amely az ideális demokráciát testesíti meg, ahogy a 11-es esküdt is megjegyzi:

„Van egy felelősségünk. Mindig is azt gondoltam, hogy ez figyelemreméltó a demokráciában (...) Minket levélben kijelöltek, hogy jöjjünk ide, erre a helyre és döntsünk egy olyan ember bünösségéről vagy ártatlanságáról, akiről sohasem hallottunk. Döntésünkkel semmit sem nyerhetünk, vagy veszthetünk. Ez az egyik olyan ok, amiért mi erősek vagyunk.” (ford. tőlem)

Természetesen e gondolat nem új keletü: például Alexis de Tocqueville (1862, p. 339), aki mindig is elismerően írt az amerikai esküdtszékről, rámutatott arra, hogy az „a legenergikusabb eszköz arra, hogy az embereket uralkodásra bírja, de a leghatékonyabb eszköz arra is, hogy megtanítsa öket jól uralkodni” (ford. tőlem).

Az igazságkeresés folyamatát a 8-as esküdt (Henry Fonda) gyanúja indítja el, aki ezzel megakadályozta az egyöntetü döntés meghozatalát. Kezdetben rajta kívül mindenki bủnösnek találta a vádlottat a gyors döntés reményében így maguk mögött hagyva az esküdtszéki szoba füllesztő hőségét. A 8-as esküdt maga sem volt biztos a fiú ártatlanságában, mégis úgy gondolta, és szépen lassan társait is meggyőzte arról, hogy

${ }^{20}$ Kivételt jelent a film végén egymásnak bemutatkozó 8. (Davis) és 9. (McArdle) esküdt. 
az ügy méltányos tárgyalása a kötelességük. A vita folyamán sorra veszik a bizonyítékokat és a tanúvallomásokat, fényt derítve a tényekre és az egyes esküdtek álláspontjának hátterére. Például az ingerlékeny 3-as esküdt személyes indítékokra, míg a hideg logikájú 4-es esküdt absztrakt szociológiai okokra alapozta a vádlott bünösségéről vallott meggyőződését. A vitában mindenki részt vehetett, függetlenül a mondanivalójától és kérdésétől. Senkit sem engedtek elcsendesíteni, amely alól csak a 10-es esküdt rasszista kirohanása volt kivétel. A történet végkifejlete az, hogy az esküdtek szépen sorjában meggyőződnek arról, hogy a vád nincs kellöképpen megalapozva, s így a vádlottat nem lehet bünösnek nyilvánítani.

Könnyen felmerülhet a kérdés: mégis hol van mindebben a vezetés? Egyfelöl a film határozottan rámutat arra, hogy a formális pozíciót betöltő vezetők nem feltétlenül vezetnek. A védőügyvédről kiderült, hogy nem képviselte megfelelően a vádlottat. Az esküdtszéket elnöklő 1-es esküdt csak a formális feladatokat látta el (például szavazást kért, összegezte a szavazatokat), s nem segítette elő a testület valódi célját: az igazságkeresést (igazságszolgáltatást). A valódi, a deliberatív-részvételi demokráciában is értelmezhető vezető a 8-as számú esküdt volt (Cronin és Genovese 2012, pp. 23839), aki a történet narrációjából (a nevek tudatos mellőzéséből) fakadóan akárki lehetne. A 8-as számú esküdt olyan vezetői erényekről tesz tanúbizonyságot, mint a bátorság, a jó ítélőképesség, a meggyőzőképesség, az érzelmi intelligencia és a szituációs érzékenység. Bátorságra vall, mikor eltérő véleményével egymaga kiállt a 11 többi esküdttel szemben. Jó ítélőképessége mutatkozott meg abban, ahogyan sorjában megkérdőjelezte a meglévő konszenzust, a bizonyítékokat és a tanúvallomások hitelességét. A cselekvés során mindvégig ő bizonyult az igazságkeresés motorjának. Sikerült kellő időzítéssel - hol keményebb, hol visszafogottabb módon - meggyőznie társait és egy új konszenzust kialakítani. Nem mellékesen, de kellö empátiával, toleranciával állt társaihoz, képes volt másokat koncentráltan meghallgatni anélkül, hogy ő maga túlzottan is domináljon. A vezetése mindvégig eltökélt volt, amely nem valamilyen konkretizálható tudásból, ismeretből fakadt, amely megalapozta volna a vádlott ártatlanságát, hanem egyfajta morális kötelességtudatból, amely az esküdtszék rendeltetésén, az igazságkeresés ideáján nyugodott. Bár a helyzet valóban steril volt adott volt a megfelelő intézményi környezet (esküdtszék) és a résztvevők (politikai) egyenlősége -, mégis a jó vezetés eredményeképp a hatalom közös gyakorlása csak vita során alakult ki. 
Összességében talán nem túlzás azt állítani, hogy a „Tizenkét dühös ember” nem egyszerüen a deliberatív-részvételi demokrácia gyakorlati müködését mutatja be, hanem valójában azt, hogy ilyen kontextusban miként lehet és kell vezetni. A demokrácia e felfogása tehát nem feltétlenül eliminálja a vezetést (vö. Pakulski és Körösényi 2012), csak annak egy egyedi típusát írja elő. Az elkövetkezőkben a deliberatív-részvételi demokrácia vezetésről alkotott elképzeléseit tisztázom. Ennek megfelelően előbb rendezem az elméleti keret demokráciára vonatkozó alappremisszáit, majd feltárom implicit vezetéselméletét kihangsúlyozva azt, hogy a vezetés miként járul hozzá a demokratikus politikához.

\subsection{A deliberatív-részvételi demokrácia alappremisszái}

Az 1970-es és '80-as évek a normatív demokráciaelméletek újjászületését jelentették, amely sok szálon kapcsolódott a John Rawls nevével fémjelzett liberális politikaelmélet térnyeréséhez. A részvételi demokráciaelméletek (B. R. Barber 2004; Pateman 1970) megjelenését követően, a '80-as évek második felétől a demokráciaelméleteket egy úgynevezett deliberatív fordulat (Dryzek 2002, p. 1; Goodin 2008, p. 2) határozza meg. Az irányzat azokból a kritikákból táplálkozott, amelyeket az elsősorban leíró, piaci analógiával élő demokráciaelméletekkel ${ }^{21}$ szemben fogalmaztak meg.

A demokráciának ezen morális felfogása (moral conception of democracy: Gutmann és Thompson 1996, p. 7) arra a feltevésre épül, hogy a demokratikus politikát csak azzal lehet erősíteni, ha az állampolgári részvételt minél szélesebb mértékben valósítják meg, vagy éppen még nagyobb teret engednek a deliberatív diskurzusnak. A deliberatívrészvételi demokrácia a (liberális) demokrácia fejlődésének következő állomását jelenti, amely a „demokratizálás”, a még „„öbb”, még „autentikusabb” demokrácia ígéretét (Dryzek 2002) hordozza magában. Másképpen fogalmazva: e megközelítés tartalmazza azt a célt, hogy növelje egyrészt az állampolgári kontrollt a döntések felett, másrészt az állampolgárok autonómiáját a politikában.

Természetesen ezt a megközelítést sem lehet egységesnek tekinteni. Amíg a részvételi demokrácia képviselői (B. R. Barber 2004; Pateman 1970) a részvétel növelését tekintik elsődlegesnek - függetlenül attól, hogy az valójában milyen politikai, közpolitikai következményekkel jár -, addig a deliberatív demokrácia ${ }^{22}$ a közvetlen részvétel mellett a döntéshozatal módjára helyezi a hangsúlyt, amely nyílt, kényszermentes, racionális és

\footnotetext{
${ }^{21}$ Ezekről bővebben lásd a következő két fejezetet.

${ }^{22}$ A deliberatív demokrácia kifejezést Joseph M. Bessette (1980) vezette be azzal a céllal, hogy leírja az amerikai kongresszus tagjainak a vitáját és egyeztetését.
} 
konszenzust eredményezö vitát jelent. Joshua Cohen (1997, p. 72) megfogalmazásában a deliberatív demokrácia koncepciója:

„...a demokratikus társulás azon intuitív ideájában gyökerezik, amelyben a társulás feltételeinek és követelményeinek igazolása az egyenlő állampolgárok közötti nyilvános érvelés és közös gondolkodás során történik. A polgárok egy ilyen rend értelmében osztoznak abban a kötelezettségben, hogy a kollektív döntések problémáinak a megoldását közös gondolkodás révén rendezik, illetőleg az alapvető intézményeiket legitimnek tekintik, amennyiben azok megteremtik a kereteket a szabad, nyilvános deliberációnak.” (ford. tőlem)

Mindazonáltal a deliberatív demokráciaelméletek is igen sokszínüek, túl az egyes szerzők között megfigyelhető hangsúlyeltolódáson, több generáció különböztethető meg az elmélet fejlődésében (Bächtiger és mtsai. 2010; Elstub 2010; Mansbridge és mtsai. 2010).

Az első generációt Jürgen Habermas (1996a, 1996b), John Rawls (1993, 1997) és tanítványa, Joshua Cohen (1997) munkái jelentik, ${ }^{23}$ amelyek a deliberációt erősen idealizált, konszenzust eredményező metódusként írják le. A demokrácia egyszerre eszköz és cél; pontosabban: morális kívánalom; ugyanis olyan univerzális morális értékeket akar érvényre juttatni, mint a méltányosság, az igazságosság, az észszerüség vagy az egyenlőség.

A második generáció munkái (Dryzek 2002; Gutmann és Thompson 1996, 2004; Young 2001, 2010) a „klasszikus idea kitágítására” (Mansbridge és mtsai. 2010, p. 67) vállalkoznak. A szerzők ebben a keretben egy realisztikusan elérhető, de normatív szempontból kívánatos demokráciakép mellett érvelnek, amely a politika kimenetelét tekintve deliberatív normákon nyugszik. Számításba veszik a feloldhatatlan morális ellentétek lehetőségét, a kommunikáció és a részvétel egyéb formáit, az önérdeken alapuló preferenciákat, de elvetik a szükségszerü konszenzus szigorú követelményét.

A harmadik generáció képviselői (Fishkin 2009; Goodin 2008) már rendszerszintű intézményi megoldásokat keresnek és politikai programot alkotnak, amelyen keresztül a gyakorlatban kívánják érvényesíteni az elmélet normatív követelményeit. Az elmélet ilyen irányú fejlődése „empirikus fordulatként” (Bächtiger és mtsai. 2010, p. 32; Elstub

${ }^{23}$ Természetesen Rawls, Cohen és Habermas elméleti fókusza és kerete számos ponton különbözik, azonban ezeket itt nem áll módomban részletesen tárgyalni (ld. erről: Bächtiger és mtsai. 2010; Elstub 2010). 
2010, p. 291) jellemezhető, amely során az elméleti megállapításokból egy, a gyakorlatban megvalósítható koncepció lett.

Összességében az irányzatok, generációk és szerzők közötti eltérések ellenére egységes elméletként kezelem a deliberatív-részvételi demokráciát, ugyanis bár azok más és más megvilágításba helyezik az ideális politikát, mégis az antik demokrácia ideájára alapozva hasonló morális igazolást, normatív elvárásokat és követelményeket fogalmaznak meg vele szemben (vö. Cunningham 2002; Pakulski és Körösényi 2012). Közös metszéspontjukat a részvételen alapuló deliberatív döntéshozatal jelenti, amelyben a deliberatív elméletek későbbi generációi - a részvételi demokrácia mellett már a részvétel szélesítésének szükségességét hangsúlyozzák. Az elkövetkezőkben az elmélet alappremisszáit tekintem át a politika bemeneti és kimeneti oldalát és folyamatát illetően.

Bemeneti oldal. A politikai folyamat katalizátora az egyenlő, szabad és közvetlen részvétel, amelynek lehetősége minden kompetens, informált, racionális és közérdekorientált állampolgár számára adottnak kell lennie. Minden érintett számára lehetőséget kell teremteni, hogy a deliberatív döntéshozatali folyamatot befolyásolhassák. A deliberációhoz szükséges a méltányos feltételek és körülmények kialakítása, amelyekkel biztosítani lehet az egyenlőséget és az inkluzív hozzáférést a vitához mind az egyének, mind az érvek szintjén. A részvétel kereteinek egyszerre kell biztosítaniuk a minőségi deliberációt; illetve bevonniuk és integrálniuk a marginalizált csoportokat, személyeket. Ezek azonban egymásnak ellentmondó kívánalmak, ugyanis a politikai kompetenciák (pl. a vitakészség vagy a racionális meggyőzés készsége) egyenlőtlenül oszlanak meg a társadalomban, de eltérő lehet a motivációk és preferenciák kifinomultsága is. Az inkluzív, egyenlő hozzáférés kívánalma kinyitja a nem deliberatív részvételi formáknak, az önérdeknek, a racionalitásnak és a részvétel átalakító hatásának a kérdését.

A demokrácia e felfogása az informális és nem konvencionális részvétel szerepét hangsúlyozza, amely elsősorban a közös eszmecserében és tanácskozásban merül ki. Azonban még olyan nem deliberatív, közvetlen részvételi formák, mint a társadalmi mozgalmak, a felvonulások és a tüntetések is hasznosak lehetnek, amelyek első látásra ellentétesek az inkluzivitás és kényszermentesség kitételével (vö. Medearis 2005). S bár az aktivizmus valóban érdeket jeleníthet meg, és a természeténél fogva észszerütlennek tünhet, mégis fontos információforrást jelenthet, és végeredményében növelheti a résztvevő állampolgárok körét (Young 2001), sőt ki is kényszeríthetik a demokratikus politika folyamatát (Gutmann és Thompson 2004, p. 51). A részvétel keretei tehát nem 
feltétlenül korlátozódnak a deliberációra, viszont a politikai cselekvésnek minden esetben abban kell kicsúcsosodnia.

A demokratikus deliberáció klasszikusan az önérdekkel és annak érvényesítésével szemben kerül megfogalmazásra. Az állampolgári preferenciák elsősorban a közjóra és a másik félre kell, hogy reflektáljanak. ${ }^{24}$ Mindazonáltal az önérdek hozzájárulhat a deliberációhoz és a konfliktusok méltányos feloldásához (Mansbridge 2006; Mansbridge és mtsai. 2010). Könnyen belátható, hogy az önérdek hasznos információval szolgálhat a meglévő konfliktusokról és magáról a közjóról. Ugyanakkor Mansbridge és munkatársai (2010) szerint az önérdeket a morális cselekvés - és az emberi jogok univerzális korlátjaihoz, valamint a kölcsönös tisztelet, az egyenlöség, a reciprocitás és a méltányosság elvén alapuló deliberatív demokrácia ideájához kell igazítani. Ez ténylegesen annyit tesz, hogy a politikai részvétel célja az önérdek „mérséklése”, ,átalakítása” a másik fél preferenciáinak, és a közjóról alkotott képének a befogadásával.

A deliberáció tehát nem egy önérdekalapú racionalitást vár el a résztvevőktől. Habermas (1996a) megkülönbözteti a stratégiai cselekvést - amely elsősorban az önérdek érvényesítésére, a haszon maximalizálására koncentrál - és a kommunikatív cselekvést, amely a kölcsönös megértésre irányul és kizárja az öncélú befolyásolást. Rámutat arra, hogy a kommunikatív cselekvés racionalitása mások igényeinek figyelembevételével konszenzusra vezet, ellentétben az önérdeket kiszolgáló politikai cselekvés instrumentális racionalitásával, amelynek keretében a cselekvő saját akaratának az érvényesítésére törekszik, kizárva ezzel mások perspektíváját. A racionalitás ezen felfogása elkerülhetetlenül értékalapú. A deliberációt tehát egyfajta értékracionalitás használva a weberi fogalmat (M. Weber 1987, pp. 53-54) - jellemzi, amely meghatározza a résztvevők meggyőződését és kötelességeit a demokratikus értékekhez igazítva.

A tanácskozásban való részvétel jelentősége transzformáló hatásában áll: egyrészt kompetensebbé és informáltabbá teszi az állampolgárokat, másrészt egymáshoz közelítve átalakítja a preferenciákat is. Számos szerző (B. R. Barber 2004, pp. 233-37; Elster 1997, p. 3; Pateman 1970, pp. 42-43) kiemeli, hogy a politikai részvétel egyszerre növeli az állampolgárok informáltságát és fejleszti politikai és morális tudásukat, és kompetenciájukat. Másképpen fogalmazva: a politikai részvétel a polgárok

${ }^{24}$ Cohen (1997, pp. 75-77) amellett érvel, hogy az önérdek kiküszöbölése elengedhetetlen a konszenzus eléréséhez. De Benjamin Barber (2004) és Jon Elster (1997) értelmezésében is kizárólag a tágabb közösségre vonatkozó érvelések elfogadhatók normatív értelemben a deliberáció során. 
számára nevelő hatással jár, azaz kompetensebbeké és (érték)racionálisabbakká válnak. S így az érzelem- és érdekvezérelt aktivizmust felválthatja a nyugodt, higgadt és ésszerü tanácskozás. A részvétel a preferenciákat is racionalizálja. A résztvevők ugyan erős, határozott preferenciákkal rendelkeznek, de azok a deliberáció folyományaként (expost) változnak, konvergálnak egymás felé. A deliberáció úgy formálja, alakítja át a preferenciákat, hogy azok a közösség egészére, a közjóra reflektáljanak. Ezzel a deliberációban résztvevők lényegében tudatosítják a közérdeket, mérsékelve saját önös érdekeiket. Így a részvétel szélesedésével megjelenő problémákat maga a részvétel és annak átalakító hatása tudja feloldani.

A politika folyamata. A politika folyamatát a tanácskozás jelenti. A deliberáció széles értelemben olyan megkülönböztetett kommunikációs formaként definiálható, amely kényszermentesen közvetíti a preferenciákat, az értékeket és az érdekeket (Dryzek 2002, p. 76). Ez a folyamat alulról fölfelé (bottom-up) épül és a középpontjában a polgárok képességeinek és preferenciáinak transzformációja áll, amely végeredményben kialakítja a közjó tartalmát és egyúttal érvényt szerez a közérdeknek.

A szigorúbb felfogás szerint a deliberatív folyamat olyan nyílt és transzparens diskurzus, amelyet racionalitása (unforced force of the better argument: Habermas 1996a), érvényessége és igazságtartalma (validity and sincierity claims: Habermas 1996a) határoz meg. A későbbi elméletek teret engednek a kommunikáció egyéb formáinak - mint a retorika, az alku, vagy a humor - azzal a határozott megkötéssel, hogy azoknak egy jelentőségteljes és ésszerü deliberációnak kell alárendelődniük (Dryzek 2002; Young 2010). E megnyilvánulási formák könnyen hasznosulnak visszahatva a politika bemeneti oldalára: szélesítik a demokratikus részvétel lehetőségeit, növelik a felek közötti bizalmat és megértést, felfedik a résztvevők értékítéleteit, perspektíváit és a közöttük húzódó konfliktusokat, illetőleg közelebb hozzák a kívánt kimenetelt. Ebben a megközelítésben a politika folyamata szekvenciákra $^{25}$, kisebb szakaszokra bomlik (Bächtiger és mtsai. 2010). Így a kommunikáció további formái anélkül integrálhatók, hogy elveszne a racionális alap, amelyhez elég egy szekvenciának magában foglalnia a racionális diskurzust. S bár így a tanácskozás fogalmilag kitágulna, mégsem válna egyszerü érdekalapú alkudozássá, irracionális meggyőzéssé és manipulációvá.

Összességében a deliberáció a konfliktusok konstruktív kezelésére, mederben tartására, esetlegesen azok feloldására és a közérdek kialakítására szolgál. Ennek kulcsa a

${ }^{25}$ A deliberáció szekvenciális megközelítéséről lásd bővebben: Goodin 2005. 
kölcsönös tiszteleten, elismerésen és reciprocitáson alapuló kommunikáció (Gutmann és Thompson 1996, 2004). Ez két dolgot is jelent. Egyfelől az egyénnek úgy kell saját preferenciáit és döntéseit indokolnia, hogy az mások számára is elfogadható legyen. Másfelől befogadónak is kell lennie a többi résztvevő hasonló szellemben megfogalmazott érvelését illetően. Pontosabban fogalmazva a résztvevőknek - mások véleményének elfogadásán túl - önreflektív módon nyitottnak kell lenniük arra, hogy saját álláspontjukat, véleményüket és preferenciáikat is megváltoztassák. Mindezek nyomán a deliberáció során ez a kölcsönösség és a másik fél egyenlő partnerként való elismerése erkölcsi kötelezettség.

Kimeneteli oldal. A deliberáció ideális esetben arra ösztönzi az állampolgárokat, hogy konszenzusra jussanak, amelyet a klasszikus szerzők nem csak szükségesnek (Rawls, Habermas), de lehetségesnek is (Cohen) tartanak. Később az elméleten belül megkérdőjeleződött, hogy valóban lehetséges-e (Gutmann és Thompson 1996, 2004), és egyáltalán kívánatos-e elérni ezt a célt (Dryzek 2002, p. 170).

Amy Gutmann és Dennis Thompson (1996) értelmezésében például a deliberáció nem feltétlenül képes meghaladni bizonyos morális, értékítéletbeli és ésszerü ellentéteket. Így a folyamat lényege abban áll, hogy lehetővé teszi azt, hogy az állampolgárok konstruktív módon együtt éljenek morális nézeteltéréseikkel a kölcsönös tisztelet, elfogadás és reciprocitás jegyében. Ezzel minimalizálhatják a vitapartnerek által vallott azon értékeket, amelyek elutasításra kerülnek. Gutmann és Thompson (1996) ezt nevezik a morális nézeteltérések gazdaságtanának (economy of moral disagreement). Az értékpluralizmus figyelembevételével a minimális cél így a mindenki által elfogadható, méltányos, kényszermentes és nem önkényes megállapodás. Ez azt is magában rejti, hogy azoknak is igazolniuk kell a döntést, akik ésszerü okoknál fogva nem értenek vele egyet. Magyarán: a deliberáció célja az általa feltárt és előtérbe helyezett konfliktusok kezelése, mederben tartása, és ideális esetben azok feloldása. Mindez azt jelenti, hogy a deliberáció folyamata, s nem annak kimenetele jelenti a demokratikus politika igazolását, a legitimáció alapját.

A deliberáció nem egyenlő a szavazással, amelyre csak másodlagos szerep hárulhat. Azonban a szavazás elkerülhetetlen, átmeneti szentesítése lehet a deliberatív döntésnek. Amennyiben a konszenzus elérhetetlennek tünik, a folyamatot szavazásnak, s így valamilyen többségi döntésnek kell lezárnia (J. Cohen 1997, p. 75). Mások (Goodin 2008, pp. 108-24; Mansbridge és mtsai. 2010; Przeworski 1998) túllépik ,a második legjobb megoldás" érvét, s egyenesen szükségesnek tartják a preferenciák aggregációját. 
Például Adam Przeworski (1998) szerint a szavazatok aggregálása jelenti a legitim autoritás valódi alapját, amely nélkül a deliberatív modell nem lenne teljes, nem lenne demokratikus. Robert E. Goodin (2008, pp. 108-24) épp az ellenkező irányból közelíti meg a kérdést. Számára a deliberáció elengedhetetlen a demokráciához, de azt szükségszerü szavazással lezárni:

„Ezért én azt ajánlom: »először beszéljünk, aztán szavazzunk«. Vagyis, helyezzük a diszkurzív és deliberatív elemeket a politika folyamat központjába, de a végső döntéseket a még tisztább aggregatív procedúrákon keresztül hozzuk meg." (ford. tőlem) (Goodin 2008, p. 124)

Ugyanakkor a szavazás nem egyszerủen kiegészítő eleme a deliberatív demokráciának (Mansbridge és mtsai. 2010). Könnyen belátható, hogy a deliberáció strukturálja a szavazást: opciókat zárhat ki, vagy akár a szavazás formáját is meghatározhatja. A bekövetkező szavazás tudatában viszont a résztvevők rá is kényszerülnek arra, hogy a problémát egy igen-nem döntésre redukálják.

Összességében a konszenzus állandó cél, de nem olyan, amit bármikor is el lehetne érni, amelyre való törekvést teljesen le lehetne zárni, ugyanis minden döntésnek nyitottnak, módosíthatónak kell maradnia a további diskurzusra. A deliberáció nem kerülhet nyugvópontra. Így „részeredményként” értelmezhetők a mindenki által elfogadható döntések és az alacsonyabb szintü metakonszenzusok a döntési folyamatról és alternatívákról. A demokratikus deliberáció valódi célja tehát szentesíteni, legitimálni a közösen hozott döntéseket, amely nem szükségképpen jelent konszenzust.

\subsection{A deliberatív-részvételi demokrácia implicit vezetéselmélete}

Számos szerző (B. R. Barber 1989, 2004, pp. 237-42; Gastil 1994; Kuyper 2012; Raelin 2012; Ruscio 2008; Uhr 2005) mutatott már rá arra, hogy a vezetés nemcsak fontos, de elengedhetetlen szerepet játszhat a deliberatív-részvételi demokráciában. Ezen munkák egyaránt normatív elméleti szintről deduktív logikával kívánják megtalálni a vezetés helyét a demokráciában. A szerzők más-más hangsúlyokat tesznek. Barber (1989, 2004, pp. 237-42) számára az állampolgárság számít központi fogalomnak, amellyel feloldja a vezetők és követők megkülönböztetését és a közvetlen, erős demokráciát hangsúlyozza. Gastil (1994) és Kuyper (2012) kifejezetten a deliberatív elméletek második és harmadik nemzedékéhez kapcsolódnak azzal, hogy a deliberatív demokrácia gyakorlatában értelmezik a vezetést mint funkciót. Ruscio a rawlsi liberális demokráciából indul ki, de ugyancsak támaszkodik a deliberatív demokrácia más 
szerzőire (például Gutmannra és Thompsonra). Némiképp külön utat járva, Raelin és Uhr saját elméletük (leadership-as-practice: Raelin 2012; prudential leadership, lattice of leadership: Uhr 2005) felöl közelítik meg a vezetés problémáját, amelyet a demokrácia e morális értelmezéséhez kapcsolnak. A hangsúlybéli eltérések ellenére a szerzők vezetésképükben osztoznak. A közös pontok a következők:

- A jó demokratikus vezetést külső viszonyítási pontok (demokratikus ideák) határozzák meg. A vezetés annyiban tekinthető jónak, amennyiben az megfelel a demokratikus értékeknek, kereteknek.

- A vezetés iránya olyan feladatokban és funkciókban fogható meg, mint a demokratikus keretek kialakítása, fenntartása, a követők politikába való beemelése és a demokratikus politika elősegítése.

- A vezetőknek olyan tudással, morális erényekkel kell rendelkezniük, amelyek segítik őket a demokratikus küldetés beteljesítésében.

- A vezetők és követők közötti kapcsolat értékeken és részvételen alapul. A szereplők között nincs éles különbségtétel, így a szerepek esetlegesek. A vezetés olyan, a demokratikus politikát elősegítő kollaboratív folyamat, amelyben bárkiből lehet vezető és amelyet a követők is aktív módon alakítanak.

Az elkövetkezőkben e kutatásokra és a kapcsolódó vezetéselméletekre támaszkodva a vezetés implicit elméletét tárom fel a deliberatív-részvételi demokrácia kereteiben.

\subsubsection{A ,jó" vezetés}

A demokratikus keretek kialakításának és fenntartásának, a követők politikába való beemelésének, valamint a deliberáció elősegítésének igényei körvonalazzák a vezetés előtt álló kihívást (1. szempont), amely egyfajta „morális alapitásként” írható le. Az alapítás, a demokratikus környezet megteremtése ebben az elméleti keretben nem merül ki a megfelelő intézményi keretek kiépítésében, hanem magában kell foglalja a politika módjának a meghatározását is. A deliberatív-részvételi demokrácia fejlődését írja elő; azaz nincs megkérdőjelezhetetlen konszenzus, „elég” széles részvétel és tökéletes demokrácia. A demokratikus politika kialakítása és fenntartása végérvényesen összefonódik és az alapítás momentuma állandósul.

A demokrácia egyszerre igényli az „alapító” és a „morális” vezetést, ahogy arra Benjamin R. Barber (1989, 2004, pp. 237-42) több helyen is felhívja a figyelmet. Értelmezésében: amíg az „,alapító” a megfelelő környezetért felel, addig a morális vezető a politikán kívül áll, mégis annak egy megfelelő irányát határozza meg. Ezen a 
ponton segítségül hívom James McGregor Burns (1978, 2003) transzformatív ${ }^{26}$ (transforming) vezetés koncepcióját, amely egyesíti az alapító és morális vezetés e formáját (Ruscio 2008). Ezért az egyszerüség kedvéért így fogom nevezni a deliberatívrészvételi demokrácia implicit vezetésképét. A transzformatív vezető nem egyszerűen egy változás elérését tüzi ki célul, hanem egy valódi rendszerszintü, mélyreható átalakulást (Burns 2003, pp. 24-25). Az átalakuláshoz „a kvantitatív változások nem elégségesek, hanem kvalitatívok is kellenek.” (ford. tőlem) (Burns 2003, p. 24) Ez nem merülhet ki intézményi átalakításokban és reformokban. Ugyanis a transzformatív vezető rendeltetése az, hogy megváltoztassa a követők, a polgárok attitüdjeit és preferenciáit. Ennélfogva itt a vezetés nem szükségképpen kötődik formális pozícióhoz, sőt annak informális oldalának a jelentősége válik különösen hangsúlyossá, amit például egy értelmiségi véleményvezér, egy progresszív reformer vagy akár egy forradalmár testesíthet meg. E demokratikus küldetés révén a vezetés három mozzanatban járul hozzá a deliberatív-részvételi demokráciához.

Az első mozzanat a morális iránymutatás. A demokratikus alapítás mind a vezető, mind a vezetett részéről magasabb morális elköteleződést követel meg. A polgároknak teljesíteniük kell kötelezettségüket, amely nem jogi, hanem elsősorban morális (Rawls 1993, p. 217) természetü. Ugyanis a deliberatív politika, ahogy arra korábban rámutattam, értékracionalitást kíván meg. Könyvében Ruscio (2008, p. 24) Rawls érvelését kibontva mutat rá arra, hogy a közös gondolkodáshoz ez a morális kötelesség a vezetőkre hatványozottan vonatkozik. A demokrácia sajátos morális karaktert igényel, amely olyan morális erényeket jelöl, mint a tolerancia, észszerüség, méltányosság, igazságosság és kölcsönös tisztelet (Ruscio 2008, pp. 27; 109). Ennek fényében a transzformatív vezetés egy olyan morális vállalkozás és kötelezettségvállalás (Burns 1978, p. 20, 2003, p. 2), amely bizonyos végső értékek (end-values: Burns 1978, p. 426) - mint a szabadság, az igazságosság és az egyenlőség - mentén, azokat érvényesítve jön létre. A vezetés által megtestesített iránymutatás az erényes és kötelességtudó cselekvésben és értékeket közvetítő állampolgári nevelésben mutatkozik meg, amelynek iránya és tartalma a vezetés morális természetéből és a vezetéshez szükséges tudásból fakad.

\footnotetext{
${ }^{26}$ Meg kell jegyeznünk, hogy ebben az esetben különösen fontos a pontos fogalomhasználat. A burnsi transzformatív vezetés (transforming leadership: Burns 1978, 2003) koncepció nem azonos Barnard R. Bass (ld. erröl: Antonakis 2018; Khanin 2007) és Joseph S. Nye (2008) transzformációs vezetés (transformational leadership) fogalmának a használatával, ugyanis az utóbbi szerzők alacsonyabbra helyezik a morális elvárások szintjét annak érdekében, hogy kiemeljék a hatékonyság szerepét.
} 
A transzformatív vezető tehát morális ágens, akinek személye morális és intellektuális támpontként szolgál. A vezető intellektuálisan stimulálja követőit, bevonja az „egész embert” a politikai interakciókba. Noha Burns (1978, pp. 23-24) kategorikusan elveti, hogy a morális vezető hasonlatos lenne Platón filozófus királyához, mégis azt az elvárást fogalmazza meg (1978, p. 42), hogy a vezetőnek a moralitás egy magasabb fokán kell állnia, mint követőinek. Sőt a vezető a végső értékek forrásává válik azzal, hogy neki kell felismerni és érvényesíteni azokat, amelynek eredményessége teljesítményének a mércéje is. A vezetőnek, mint a demokratikus filozófuskirálynak döntenie kell arról, hogy mi demokratikus és mi nem, értelmeznie és érvényesítenie kell a morális alapon álló demokráciát.

Ugyancsak túl kívánja lépni Burns (1978, pp. 45-46) a weberi érzületetikát (M. Weber 1989, pp. 71-88), azonban a végső értékek abszolút jellegüknél fogva hasonló értékelési metódushoz vezetnek (ld. erről: Kane 2001, pp. 29-30):

„A morális vezetés végső próbája az a képesség, hogy meghaladja a mindennapi igények, szükségletek és elvárások sokféleségét, elősegítse a morális fejlődés egy magasabb szintjét, és összekapcsolja a vezetői magatartást - szerepeit, választásait, stílusát, kötelezettségvállalásait - az indokolt, viszonylag explicit, tudatos értékek egy csoportjával.” (ford. tölem) (Burns 1978, p. 46)

A végső értékek lesznek a vezetés megítélésének mérőeszközei függetlenül attól, hogy az azokra alapozott célok reálisan megvalósíthatók lennének-e, vagy hogy a cselekvés milyen konkrét következményekkel jár. Ha a transzformatív vezető - és a követői viselkedését valamiféle abszolút etika, abszolút értékek mentén definiálják, akkor elkerülhetetlen az a következtetés, amire Weber is rámutatott:

„[h]a egy tiszta érzületből fakadó cselekedet következményei rosszak, akkor azért a cselekvő szemében nem saját maga, hanem a világ, mások ostobasága (...) a felelős. (...) Az érzületetika híve csak azért érez „felelősséget”, hogy a tiszta érzület lángja - például a társadalmi rend igazságtalansága elleni tiltakozásé - ki ne aludjék.” (M. Weber 1989, p. 75)

A transzformatív vezetővel szemben az az elvárás fogalmazható meg, hogy mindvégig, minden áron és a végsőkig kiálljon az ,igaz” ügy: a demokrácia és a végső értékek ügye mellett. A vezetés hatékonysága ilyen értelemben az állhatatosságban, a kitartásban, pontosabban a végső értékekhez való ragaszkodásban értelmezhető, mivel ezen célok megvalósulása nem csak a vezetőn áll. A vezetés akkor lesz hatékony, ha az minden 
körülmények között kitart demokratikus küldetése mellett. $\mathrm{S}$ ezzel az elmélet premisszáihoz igazodva egyfajta értékracionalitás várható el.

A vezetőnek egyfajta ideológiai, filozófiai „abszolút” tudás (episztémé: Körösényi 2005, p. 233) birtokosaként kell feltünnie (2. szempont). A vezetőnek, morális cselekvőként, képesnek kell lennie a deliberatív-részvételi demokrácia követelményei, körülményei közepette a helyes eszközök kiválasztására és azok magasabb morális célokhoz rendelésére. Tudatában kell lennie annak, hogy milyen végső értékek mentén kell kialakítania a deliberáció és a részvétel kereteit, $\mathrm{s}$ milyen eszközök állnak a rendelkezésére. Ez nem valami speciális tudást jelent, amelyre szüksége van egy bürokratának vagy egy szakértőnek. Itt a vezetésnek arra kell törekednie, hogy eltüntesse, feloldja azt a hézagot, amely a végső értékekből fakadó közös vízió és a realitások között tátong (Burns 2003, p. 167; Heifetz 1994, p. 22). Ilyen értelemben a vezetés az igazság keresését (truth-seeking) és közvetítését (truth-giving) is jelenti. A vezető nem információt oszt meg, de nem is egyszerüen kinyilatkoztat, hanem kreálja, igazolja és elfogadtatja a kollektív tudást a deliberáció során. Így az igazság keresése közben nem határozza meg a közjó, a közérdek tartalmát, hanem csak megfelelö kérdéseket tesz fel s ilyenformán hat a politikai napirendre. Az igazság közvetítése csupán az értékekre vonatkozik, amellyel nem mondja meg effektíve, hogy a követők mit gondoljanak, csak azt, hogy miként gondolkodjanak.

A második mozzanat a konfliktusok konstruktív kezelése, mederben tartása a deliberáció elősegítése révén. A konfliktusok, mint nézeteltérések, lehetőségként jelennek meg, amelyek révén az állampolgárok közötti jobb megértés, erősebb kölcsönös tisztelet és egy új, mindenki által elfogadható megállapodás alakulhat ki. A deliberatív politikai folyamatban a konfliktusok tehát gerjesztik az integráló, új és kreatív megoldásokat a közösség problémáira (Follett 1942a). ${ }^{27}$ Ily módon a konfliktusok felfrissítik és paradox módon erősítik a demokráciát, müködésben tartják a delibrációt és lehetővé teszik az állampolgári preferenciák transzformációját és közeledését egymáshoz. Ennek érdekében a transzformatív vezetés kifejezi, formálja és felhasználja ezeket a konfliktusokat (Burns 1978, 2003; Heifetz 1994). Így a vezető számára a feladat itt abban áll, hogy miként tudja a deliberáción - kölcsönös tiszteleten,

\footnotetext{
${ }^{27}$ Mary Parker Follett (1942a, pp. 3-4) klasszikus példája erre az a kölcsönösen nyertes (win-win) szituáció, amikor a könyvtárban valaki kinyitná az ablakot, hogy hüvösebb legyen, míg mások nem szeretnének huzatban ülni. A megoldás számára az, hogy egy másik szobában nyitják ki az ablakot, így nem alakul ki huzat, de mégis lehül a levegö.
} 
elismerésen és reciprocitáson alapuló kommunikáción - keresztül a konfliktusokat konstruktív módon kezelni.

Ehhez a vezető nem megtestesíteni, tükrözni kívánja a közérdeket, hanem annak határait morális értelemben tágítani, azaz: elősegíteni a preferenciák transzformációját. Másképpen fogalmazva a transzformatív vezetőnek ugyan különösen fogékonynak kell lennie a követők igényeire és akaratára, ugyanakkor nem keresheti azok utilitarista beteljesítését. A résztvevők elköteleződnek egymás mellett: felfogják egymás szükségleteit, motivációit, illetve közössé teszik értékeiket. A befolyásgyakorlás itt nem egy mechanikai jellegü folyamat, hanem egy morális fúzió, amelyben a célok és a motivációk összekapcsolódnak egy mindenki által elfogadható és méltányos megállapodás kialakulását elősegítve. Ez nem egyszerü kompromisszum, hanem lényegében egy „összefogás” a közös célért. A transzformatív vezetésnek tehát fel kell ismernie a követők „,valódi” morális szükségleteit; fel kell fednie az értékek egymás közötti és/vagy az értékek és a gyakorlat közötti konfliktusokat; rá kell mutatnia az értékekre; növelnie kell az általános társadalmi tudatosságot; át kell akár szerveznie az intézményeket, és kormányoznia kell ezt az átalakulást. A vezető fundamentális feladata ösztönözni a polgárokat arra, hogy tisztában legyenek a preferenciáikkal annak érdekében, hogy képesek legyenek definiálni az értékeiket, szükségleteiket és céljaikat (Burns 1978, pp. 43-44).

Érdemes ehelyütt előhívni a burnsi elméletet továbbgondoló Ronald Heifetz (1994) értelmezését. Számára ezen konfliktusok olyan adaptív kihívások (adaptive challenges), amelyek esetében a probléma és a megoldás is közös értelmezést igényel. Nincsenek egyértelmű válaszok, sem megoldások, sem technikák. A vezetők és a követők rákényszerülnek, hogy folyamatosan tanuljanak: értelmezzék és feloldják a konfliktusokat. A gyógyítás példájával szemlélteti mindezt Heifetz (1994, pp. 73-76). Egyes betegségekre nincsenek evidens és könnyen alkalmazható gyógymódok. Ilyen esetekben mind az orvosnak, mind a betegnek is részt kell vennie a diagnózis felállításában. Mindketten az igazságot keresik: az orvos tüneteket keres, a beteg elpanaszolja a fájdalmait. Ezt követően az orvos a diagnózis alapján meghatározza a kezelés menetét, viszont a kívánt állapot, a javulás csak akkor realizálódhat, ha a beteg maga is tesz a gyógyulásáért. Az ilyen jellegü problémák kizárólag a követők feltételezéseiben, hiedelmeiben, szokásaiban és vállalt kötelezettségeiben történő változások (demokratikus transzformáció) elérésével kezelhetők. A konfliktus kezeléséhez és a kihívás leküzdéséhez a követőknek is aktív szerepet kell vállalniuk, 
mégis a probléma keretezése és a nyilvános vita irányának a meghatározása a vezető feladata marad. Ennek fényében a vezető támogatja, keretezi és felügyeli a deliberációt (Gastil 1994, pp. 960-62) azzal, hogy megfelelően tölti be a moderátor szerepét: egyszerre kell beszélnie a követőkhöz, és hallgatni is rájuk. Összességében az adaptív feladatokra reagáló vezetés sikere a polgárok szükséges mobilizálásában, motiválásában, a figyelem fókuszálásában, valamint a deliberáció elősegítésében és fenntartásában áll.

A harmadik mozzanat a követők politikába való beemelése (empowerment: Burns 2003, pp. 25-26; 182-85; Ciulla 2014a; Gastil 1994, pp. 959-60; Perkins 2010). A deliberatív-részvételi demokrácia kereteinek a kialakítását, a deliberáció beindítását követően a vezető - akár Rousseau felvilágosult, bölcs törvényhozója - dolga végeztével szükségszerüen háttérbe vonul. Ezzel párhuzamosan a vezető altruista módon lemond a vezetésről, elősegíti a részvételt és a deliberációt, amelyhez a követőket „felhatalmazza”, „felemeli”, vagyis a követőkre átruházza a hatalmat. Ennek lényege abban áll, hogy a vezetőnek nem elég transzformálnia a preferenciákat, de lehetőséget kell biztosítania arra is, hogy a követők vezetőkké váljanak, amellyel lényegében a polgárok politikai kompetenciáinak, tudásuk átalakításának a lehetőségét nyitja ki. Ezzel a transzformatív vezetés mélyebb, morális igényeket, vagy millsi értelemben vett magasabb rendü élvezeteket kíván kielégíteni, amely megegyezik a burnsi felfogásban a „boldogságra való törekvéssel” (Burns 2003, pp. 1-3; 227-30).

Ezen a ponton lényegében feloldódni látszik a paternalizmus vádja (Pakulski és Körösényi 2012, p. 86; vö: Rostbøll 2005), amely a deliberáció és az autonóm preferenciaformálás szabadságának beszükülését, a folyamat ellehetetlenülését rója fel e demokráciaelméletnek. Ugyan a vezetöre, mint morális ágensre, a folyamat védnökére, gondnokára és fenntartójára szükség lehet (B. R. Barber 1989, 2004, pp. 237-242; Gastil 1994; Ruscio 2008), mégis a felhatalmazás pillanatában, lehetővé teszi a követők vezetővé válását, amellyel a paternalista jelleg lényegében megszünik egy adott helyre, időre és személyekre vonatkozóan. A követőknek szabadságukban áll nem csak „,követni”, hanem lehetőségük van vezetővé is válni, azaz: maguk is alakíthatják a deliberáció mikéntjét és kérdést tehetnek fel. A morális alapítás bár állandósulhat, de a paternalizmus problémájának időről időre (szimbolikusan legalábbis) fel is kell oldódnia. Leegyszerüsítve a különbségnek el kell homályosulnia, amelyet a felhatalmazás folyamata tesz lehetővé. Ellenkező esetben a morális ágens „hamis prófétává" válik, azaz a transzformatív vezetés kiüresedik. 
Tisztán kell látni, hogy a vezetés számára nem egyszerüen a polgári részvétel és az elköteleződés növelése a cél, hanem a követők felhatalmazása, amely abban mutatkozik meg, hogy a vezető reflektál a követők magasabb morális igényeire (Burns 2003, pp. 183-85). A felhatalmazás egy olyan folyamat (Ciulla 2014a; Perkins 2010), amely lehetővé teszi, hogy a követők részt vegyenek a döntéshozatalban a vezető engedélye vagy felügyelete nélkül. Ennek keretében a polgárok átveszik az ellenőrzést közösségi életük, a demokratikus politika és környezetük kritikai értelmezése felett. Erősödik a kölcsönös tisztelet és gondoskodás, valamint a kritikai reflexivitás. A felhatalmazással a vezető kellő önbizalmat táplál a követőkbe, fejleszti kompetenciáikat, valamint lehetőséget és forrásokat biztosít számukra az önálló döntések meghozatalához. Ilyen módon teljesedik be az egyének politikai tudására, kompetenciáira vonatkozó transzformáció, a „politikai nevelés”. Amíg a transzformatív vezetés iránymutatással és konstruktív konfliktuskezeléssel közös tudást, addig a felhatalmazás a valós és mély politikai részvétellel közös tapasztalatot hoz létre. Itt már a vezetés kevésbé az iránymutatásról, hanem inkább a polgároknak a közös célok elérése érdekében történő bevonásáról és a vezetési funkció elosztásáról szól.

Ezt a mozzanatot leginkább a tanár hasonlatával lehet szemléltetni (B. R. Barber 1989). A tanár akkor jár el helyesen, ha nem arra tanítja a diákjait, hogy mit gondoljanak, hanem hogy miként gondolkodjanak. A diákoknak legfőbb feladata elsajátítani a kritikai önállóságot és a független gondolkodásra való képességet. A tanár tevékenysége önellentmondó, hiszen célja az, hogy ő maga feleslegessé váljon, másképpen fogalmazva: a diákoknak ne legyen már szükségük rá. A vezető azért vezeti a követőket, hogy azok később vezetni tudjanak, s ilyen módon segíti elő a demokráciát. Barber (1989, p. 121) a következőképp fogalmazza meg a helyes gyakorlatot:

„Erős demokratikus vezetés az, amelyben a vezető távozásakor az állampolgárokat a vezetésre még képesebbnek hagyja hátra, mint ahogy az az érkezésekor fennállt. Ez az a vezetés, amely azzal tud dicsekedni: »Most, hogy ő [a vezető] elment, csinálhatjuk mi magunk is. «" (ford. tőlem)

Tökéletesen fogja meg ezt az elképzelést, elvárást Lao-ce közhelyként forgó gondolata is, amelyet Barber is idéz:

„Egy vezető akkor a legjobb, ha az emberek alig veszik észre a létezését. Kevésbé jó, ha az emberek szolgálják és éljenzik, és a legrosszabb, ha már megvetik öt. (...) A jó vezető keveset beszél, és ha munkáját elvégezte, 
céljai megvalósultak, az emberek azt mondják: mi magunk, egyedül csináltuk.” (ford. tőlem) (idézi: B. R. Barber 1989, p. 121)

A vezető lényegében beemeli a követöket a demokratikus politikába lehetőséget teremtve a közvetlen részvételnek, illetve létrehozva és fenntartva a folyamat bottom-up jellegét. A felhatalmazás módosítja a vezetők és a követők jogait, kötelességeit és felelősségi körüket is. A vezetés egy olyan demokratikus környezetet hoz létre, melyben a követők motiváltak, hogy vezetők lehessenek, és fordítva: a vezetők nyitottak arra, hogy követőkké váljanak. Azaz: a követők túlnőhetik vezetőiket és lényegében maguk is vezetökké válhatnak. A vezetők és a követők között lényegében egy kölcsönös felhatalmazás folyamata jön létre, amelyben a vezetői és követői szerepek rövid életủek és nem is feltétlenül egyértelműen különíthetők el. A vezetést e mozzanat - ahogy azt Burns (2003, p. 26) is aláhúzza - teszi igazán részvételivé, és a fentebb meghatározott mércék mentén demokratikussá.

\subsubsection{A „helyes” kapcsolat a vezetők és a követők között}

A deliberatív-részvételi demokráciában a közvetlen részvétel és a politikai folyamat bottom-up jellege központi elem, amely kritikussá teszi a követés kérdését. Ebböl fakadóan a követés az elmélet nézőpontjából nem jelenthet alárendelt vagy passzív szerepet. A morális alapítás felhatalmazás mozzanata arra mutat rá, hogy a vezetők és a követők közötti különbség szükségszerüen elmosódik, kapcsolatuk és az interakciók pályája horizontálissá válik és a morális iránymutatás révén értékalapú kötődést hoz létre (4. szempont). Ilyen értelemben egyfelöl a transzformatív vezetésben egyszerre lesz mindenki és senki sem követő, másfelől az univerzális, abszolút értékekre alapozott morális iránymutatásból következően a vezetés mindenkire vonatkozik, mindenkit morálisan kötelez.

Ez azt jelenti, hogy a vezetők és a követők kölcsönösen aktív (koaktív), kezdeményező felekké válnak a kapcsolatban (5. szempont). A vezetés, amely lényegében a deliberáció irányát testesíti meg, megosztott ${ }^{28}$ gyakorlattá válik, amelyben az informális vezetői szerep rotálódik (Gastil 1994, pp. 958, 962-63; Raelin 2012), illetőleg a deliberatív folyamat fenntartásának feladata és felelőssége is megoszlik a résztvevők között (B. R. Barber 1989, pp. 121-25, 2004, pp. 239-40; Gastil 1994, pp. 960-62; Kuyper 2012). Itt a vezetői szerep nem feltétlenül formális pozícióhoz kötött. A résztvevők vezetik „,saját

\footnotetext{
${ }^{28}$ A vezetéskutatásban számos horizontális kapcsolatot feltételező modell van, úgymint: a szétosztott(distributed leadership: Gronn 2002), a megosztott vezetés (shared leadership: C. L. Pearce és Conger 2003) és a vezetés, mint gyakorlat (leadership-as-practice: Raelin 2012). Ezek egyre nagyobb hangsúlyt kapnak a vezetéskutatásban (ld. erről az 1.3.4. fejezetben a „A vezetéstől való félelem csapdáját”).
} 
magukat", de engedik is, hogy más vezesse őket reciprok befolyásoló folyamaton keresztül. A közös cselekvés egyfajta vezetővel telített gyakorlat (leaderful practice: Raelin 2012), amelyet a résztvevők közötti interakció, kommunikáció, deliberáció hoz létre és formál. Ebben az értelmezésben, habár a formális pozíciókat ellátó személyeknek kell elősegíteniük és moderálniuk a deliberatív folyamatot, a vezetés mégsem kizárólag az ő kezükben koncentrálódik.

A vezetés funkciójának a szétszórása nemcsak a közvetlen részvétel kitágítását jelenti, hanem a politikai nevelést - a morális iránymutatást és felhatalmazást - is szükségessé teszi. Az érintettek nem egyszerü szemlélői vagy fogyasztói a demokratikus politikának, hanem annak - s így a közérdeknek és közjónak is - társalkotói. Leegyszerüsítve: itt a vezetés tudatos követést igényel (B. R. Barber 1989; Gastil 1994, pp. 963-64). A követők kellő kompetenciával, információval kell, hogy rendelkezzenek; és képesnek kell lenniük arra, hogy átlássák az alternatívákat, hogy racionális szereplőkként részt tudjanak venni a deliberációban. Mindazonáltal a polgároknak nemcsak tudniuk kell kifejezni a véleményüket, de meg is kell hallgatniuk másokét. A másik fél érdekeit nem csak artikulálniuk kell, de lényegében magukévá is kell tudni tenniük. A követőknek kritikusnak kell lenniük a vezetőikkel szemben, de fenn is kell tartaniuk saját autonómiájukat. A vezetés megosztásával lényegében az az elvárás fogalmazható meg, hogy a követőknek képesnek kell lenniük felmérni, mikor kell vezetőként funkcionálniuk. Szem előtt tartandó azonban, hogy ebből nem következik az, hogy a demokratikus vezetés megkérdőjelezhető lenne, ugyanakkor az inkompetens vagy immorális vezető elutasítása a követők kötelessége.

Ahogy a vezetés, úgy a hatalom ${ }^{29}$ is valamilyen formában megoszlik a cselekvésben résztvevő felek között. A hatalom a vezetés esetében egy kapcsolatként került megfogalmazásra (Burns 1978, p. 13), amelyet lényegében a felhatalmazás (empowerment) újra kíván fogalmazni. A hatalom itt egy kollektív képességet jelöl, amely leszúkíti a kényszer (szankció, fenyegetés) alkalmazásának lehetőségét, amely ellentétes lenne a deliberatív elméleti kerettel. A hatalomgyakorlás több ponton is feltünhet ebben a keretben: a deliberatív folyamatot minden esetben moderálni, a meglévő egyenlőtlenségeket csökkenteni kell; és a döntéseket is végre kell hajtani (Mansbridge és mtsai. 2010).

\footnotetext{
${ }^{29}$ Itt szükségszerủ megjegyezni, hogy a deliberatív-részvételi demokrácia nem zárja ki a hatalom meglétét, még ha a klasszikus elméletek annak hiányát írják is le az ideális deliberatív folyamatban (Mansbridge és mtsai. 2010).
} 
A hatalom itt a politikai közösségen nyugszik (Arendt) és maga is egy interszubjektív kommunikáció terméke, a deliberáció eredménye (Habermas). Hannah Arendt értelmezését (Balázs 1998, pp. 86-89, 2003, pp. 123-25) használva: itt a hatalom nem kizárólagosan egyéni cselekvési képességekre utal, hanem azt is jelenti, hogy valaki másokkal összhangban képes cselekedni. A hatalom a közösség, a társadalom tagjainak szabad együttmüködését takarja, amely ilyen értelemben sohasem egy egyén kizárólagos tulajdona, ugyanis annak megléte az azt létrehozó közösségtől függ. A hatalomgyakorlást valamilyen konszenzus, beleegyezés és önkéntes együttmüködés aktusa előzi meg, ahogy azt Habermas ${ }^{30}$ (1996b; ld. erről: Balázs 1998, pp. 89-93, 2003, pp. 125-27) is kiemeli és amelynek megléte a hatalom, mint közösségi cselekvőképesség megőrzésének a feltétele is. Az erőszak és a manipuláció ellentétesek a hatalom ezen felfogásával, hiszen azok aláássák magát a közösséget.

A vezetők és a követők hatalmi kapcsolatát Mary Parker Follett vezetéskutató koncepciójával lehet a legpontosabban leírni (3. szempont). Ez a hatalomnak másokkal együtt való gyakorlása (power with: Follett 1930, pp. 179-94, 1942). A hatalomgyakorlásban rejlő kényszer csökkentésének nemcsak morális, de hatékonyságbéli megfontolásai is lehetnek. Az „egyenlő hatalom” a méltányos konfliktuskezelés színterét és a résztvevők integrálásának lehetőségét adja. Ez a hatalomgyakorlás közös létrehozását és fejlesztését jelenti, amely nemcsak hogy valódi formája (Follett 1930, p. 189), de egyben az egyetlen legitim megnyilvánulása is a hatalomnak:

„Amikor te meg én elhatároztuk magunkat bizonyos lépések megtételére és végrehajtjuk azokat, akkor neked nincsen hatalmad felettem, ahogy nekem sincsen feletted, de hatalmunk van magunk fölött közösen (...) csak az a hatalom lehet legitim részünkröl John Smith-szel szemben, amit te, John Smith és én közösen fejlesztünk magunk számára.” (ford. tőlem) (Follett 1930, p. 186)

Értelmezésében a hatalom problémája nem az, hogy miként lehet mások felett kontrollt gyakorolni; hanem az, hogy miként lehet az adott szituációt, problémát közösen kézben tartani és megoldani a hatalom segítségével. Arendthez és Habermashoz hasonlóan a hatalom itt is közösségi képesség, de Follett annak használatára egy meghatározott irányt, feladatot ír elö. A hatalomban rejlő kényszer meghaladása tehát abban áll, hogy a

\footnotetext{
${ }^{30}$ Ezen a ponton a deliberációhoz kapcsolható kommunikatív hatalom tárgyalása tünik fontosnak. Ezért nem foglalkozom a kommunikatív- és az adminisztratív hatalom kapcsolódásával (Habermas 1996b, pp. 28-29).
} 
résztvevők képesek-e felismerni, értelmezni és elfogadni a helyzet törvényét (law of the situation: Follett 1942c), a közös problémát, valamint a közös érdeket és ilyen módon egységbe rendeződni; ugyanis immáron mindenki a helyzettől kapja az utasításokat. Ez egyfajta „körkörös” vezetést (circular behavior/response) teremt, amelyben a vezetés feladatai, a funkciók megoszlanak a résztvevők között aszerint, hogy ki képes az adott helyzetre a legmegfelelőbb választ adni. Pontosabban fogalmazva: a vezetés attól az egyéntől származik, aki épp az adott szituációhoz mérten a legrelevánsabb képességekkel és tudással rendelkezik.

„Hogyan csökkentsük a hatalom mások feletti gyakorlását? (...) A körkörös viselkedés az integráció alapja. Te befolyásolsz másokat, míg ők befolyásolnak téged. Ha mindkét fél engedelmeskedik a helyzet törvényének, akkor egyetlen személynek sincs hatalma a másik felett.” (ford. tőlem, kiemelés az eredetiben) (Follett 1942b, p. 83)

Itt tehát a vezető nem egyszerüen megosztja a hatalmát, hanem másokkal közösen létrehozza és fejleszti azt annak érdekében, hogy a problémákat megoldják. Ezzel a két, akár ellentétes érdekkel és célokkal rendelkező fél között is egység jön létre.

Összegezve, a hatalmi kapcsolatot illetően a következő megállapítások tehetők a deliberatív-részvételi demokrácia implicit vezetés elméletében: (1) a kapcsolat az egyének önkéntes akaratán alapuló együttmüködésből fakad, amely a vezető részéről nem a hatalom megosztását, hanem a követők hatalomba való beemelését (empowerment) jelenti; (2) a hatalom kollektív cselekvőképesség, azaz csak másokkal együtt (power with) lehet létrehozni és gyakorolni; (3) a hatalmi kapcsolat célja az együttmüködés fenntartása és a közös problémák konstruktív orvoslása. Ennélfogva a hatalmi távolság lecsökken és az interakciók nyílttá válnak.

\section{3. Összegzés}

Ebben a fejezetben amellett érveltem, hogy a demokrácia morális értelmezését (Gutmann és Thompson 1996, p. 7) adó részvételi-deliberatív demokráciaelmélet az általános feltételezésekkel ellentétben (vö. Pakulski és Körösényi 2012) nem, hogy nem eliminálja, de implicit módon még igényli is a vezetést.

A fejezet első felében az elmélet demokráciára vonatkozó premisszáit fogalmaztam meg. Az elmélet értelmezésében a politikai folyamat bemeneti oldalán a közvetlen, informális részvétel jelenti a politika folyamat katalizátorát, amelyben az állampolgárok közérdek-orientáltak, racionálisak, kellőképpen kompetensek és informáltak. A politikai 
folyamat ennek megfelelően alulról fölfele (bottom-up) építkezik. A politikai folyamatát a deliberáció jelenti, amely lehetővé teszi a preferenciák többoldalú alakítását és (expost) formálódását. A politika tehát két irányból is transzformatív hatású. Egyfelől a részvétel során az állampolgárok kompetensebbé, informáltabbá és közérdekorientáltabbá válnak. Másfelől a politikai folyamat a preferenciákat egymáshoz közelítve átalakítja és racionalizálja. Ily módon a folyamat (vég)eredménye - a konszenzus állandó keresése mellett - egy minden szereplő által elfogadható és méltányos megállapodás. A szavazás intézménye az elmélet szemszögéböl másodlagos és csak a deliberáció időleges lezárását jelenti. Fontos aláhúzni, hogy a deliberáció célja nem egy megkérdőjelezhetetlen konszenzus kialakítása, hanem a közösen meghozott döntések legitimálása.

A fejezet célja az implicit vezetéselmélet feltárásával az volt, hogy rámutasson miképpen járul hozzá a vezetés a deliberatív-részvételi demokrácia által előírt és elvárt politikához. A morális alapítás egyszerre teszi lehetővé az állampolgári részvételt és alakít ki megfelelő demokratikus politikát. Az ideológiai és filozófiai „abszolút” tudásra (episztémé) alapozott morális iránymutatással a vezető megfelelő kérdésfeltevéssel keresi, és a közös gondolkodás mikéntjének meghatározásával közvetíti is az igazságot. Fontos azonban leszögezni, hogy ez az iránymutatás semmiképpen sem megkérdőjelezhetetlen kinyilatkoztatás, hiszen a vezetőnek politikai neveléssel be is kell emelnie a követőket a politikába (empowerment), hogy később maguk is vezetőkké válhassanak. Ennélfogva a vezető két módon segíti elő az állampolgárok transzformációját. Egyfelől a morális iránymutatással a vezető képes elősegíteni a preferenciák (ex-post) alakítását, racionalizálását és egymáshoz való közeledését. Ennek központi magját a konfliktusok konstruktív kezelése, azaz a deliberáció kényszermentes, kölcsönös tiszteleten és reciprocitáson alapuló kommunikáció folyamatának a kialakítása és fenntartása adja, amelynek eredményeként jön létre a mindenki által elfogadható, méltányos, kényszermentes és nem önkényes megállapodás. Másfelől a követők felhatalmazásával, a részvétel elősegítésével a vezető az állampolgárok fejlődését is támogatja. Ezzel lehetővé teszi a hatalom együttes gyakorlását (power with), a követök és vezetők kölcsönösen aktív (koaktív) jelenlétét és a közöttük lévő interakciók horizontális jellegét, amelyekből együttesen következik a valós és közvetlen részvétel és az alulról fölfele épülő folyamat. 


\section{4. VEZETÉS AZ AGGREGATÍV-RÉSZVÉTELI DEMOKRÁCIÁBAN}

Bár a klasszikus képviseleti demokráciát újrafogalmazó aggregatív-pluralista demokráciaelmélet keretében már nem tűnik első látásra idegennek a vezetés gondolata, mégis annak egy egyedi esetét igényli. Ez a vezetés nem vetít elöre nagyobb változtatásokat vagy még demokratikusabb politika kialakítását, mint a transzformatív vezetés, sőt mozgástere több szempontból is kötött és korlátozott. Ennek ellenére a vezetés elengedhetetlennek tünik az aggregatív-pluralista demokráciában.

Ezen a ponton megint segítségünkre lehet egy fiktív példa. Az európai közönség előtt talán kevésbé ismert alkotás Frank Capra 1939-es „Becsületböl elégtelen” (Mr. Smith Goes To Washington) címet viselő filmje ${ }^{31}$, amely az amerikai politikai rendszert és a demokrácia törékenységét ábrázolja. A film jelentőségét a történelmi kontextusa adja. Nem tekinthető véletlenek, hogy a filmet 1939 októberén mutatták be pár héttel Lengyelország megszállása és a második világháború kitörése után. Hans von Kaltenborn, a kor ismert rádió kommentátora saját magát alakítva a film egyik emblematikus jelenetében úgy fogalmaz, hogy a Szenátus karzatán helyett foglaló diktatúrák diplomatái tanúi lehetnek a demokrácia müködésének. („In the diplomatic gallery, are the envoys of two dictator powers. They have come here to see what they can't see at home: democracy in action.") A film bemutatójában úgy fogalmazott, hogy a film azért tekinthető jelentős alkotásnak, mert a demokrácia működését és gyakorlatát hangsúlyozza. Mindebben a vezetés, amely tiszteletben tartja a demokrácia intézményét és érvényesíti a meglévő állampolgári érdekeket, elengedhetetlen szerepet kap.

A filmszatíra főhőse egy naiv, idealista és kisvárosi átlagember, Jefferson Smith (James Stewart), akit egy megüresedett szenátori helyre neveznek ki. Smith államát egy befolyásos oligarcha, Jim Taylor tartja a kezében, aki annak reményében támogatja és szentesíti a kormányzó döntését, hogy az ifjú, idealista és naiv szenátort könnyen tudja majd manipulálni. A cselekmény feszültsége a közöttük lévő konfliktusban bontakozik ki. Smith egy törvényjavaslatot - melyet a történet a közérdeknek feleltet meg - dolgoz ki, és nyújt be azzal a céllal, hogy a városi fiatalok számára erdei tábort létesítsenek.

${ }^{31}$ Lásd Capra és az említett film vezetésképéröl még (Cronin és Genovese 2012, pp. 255-57) elemzését. 
Azonban az elképzelése ütközik Taylor érdekével, illegális ügyletével. Mivel Smith szenátortársának, a korrupt Joseph Harrison Paine-nek a nyomására sem áll el a tervétől, Taylor politikai szövetségeseivel, hamis tanúkkal megpróbálja hitelteleníteni, megrágalmazza őt azzal, hogy saját hasznát keresi a tábornak szánt földterület kisajátításában. S amikor Smith éppen elveszítené a hitét, és nem mellékesen a pozícióját, a ,filibuster" eszközével kiáll az igazáért és a demokráciáért (Kaltenborn: „,democracy's finest show: the filibuster”). Ekkor indul be Taylor propagandagépezete az írott sajtóban, a rádióban, és a tömegrendezvényeken (,,Stop Smith!”), melyekkel a nép haragját igyekszik Smithre irányítani. Végül Paine pálfordulásával fény derül az igazságra: beismeri büneit és felfedi Taylor üzelmeit.

A történet két vezetőt vázol föl: Taylort és Smitht. Az elöbbi testesíti meg a „rossz”demagóg és manipulatív - vezetőt, aki semmibe veszi az alkotmányos intézményeket és a közérdeket. Ő „megcsinálja” a közvéleményt (,I'll make public opinion out there within five hours") - állítja -, s nem igazodik hozzá. Ezzel szemben Smith ,jó” vezetőként mindenféle manipuláció nélkül az eleve adott közérdeket igyekszik mindenáron érvényesíteni. Mindazonáltal átlagos képességekkel rendelkező vezetőként egyedül a politikai rendszer, az intézmények (,I can promise you one thing, I'll do nothing to disgrace the office of - the United States Senate"), az Alkotmány ${ }^{32}$ és az alapító elnökök tisztelete teszi különlegessé ${ }^{33}$. Ilyen értelemben hétköznapi hős bárkiből lehet, aki elég ,jó” (kötelességtudó és törvénytisztelő) állampolgár. Capra szándéka világos: kihangsúlyozni a közérdektől eltávolodott, korrupt, manipulatív politikai elit és a klasszikus, feddhetetlen népi hős ideája közötti kontrasztot. Annak ellenére, hogy Smith a követők mobilizálásában (a kollektív cselekvés beindításában) alulmaradt, mégis „természetes” demokratikus vezetővé vált az intézményekhez való morálisan helyes viszonyulásának, a közérdek helyes megformálásának és a rendelkezésre álló hatalmi eszközök kitartó használatának, azaz - a történet során elsajátított - technikai jellegü tudásának köszönhetően. Vezetése képes volt a demokráciát megvédeni.

Noha Capra romantikus és szentimentális története a kisember könyörtelen és korrupt politikai hatalommal szemben folytatott harcáról sok tanulságot hordoz magában a demokratikus vezetés e típusáról, mégis több megválaszolandó kérdést is felvet. Az első ilyen kérdés arra vonatkozik, hogy milyen az a demokrácia, amit meg kell védeni?

\footnotetext{
${ }^{32}$ Például a filibuster során Smith az Egyesült Államok Alkotmányából és Függetlenségi nyilatkozatából olvasott fel.

${ }^{33}$ Smith többször is ellátogat a Lincoln-emlékmühöz, ahol hitvallásként idézik a volt elnök szavait a gettysburgi beszédéből: ,,a nép kormányzása, a nép által, a népért nem tűnhet el soha a föld színéről.”
} 
Azaz: milyen alappremisszákban határozható meg a demokrácia aggregatív-pluralista felfogása? A kérdések második csoportja már a vezetés implicitelméletére vonatkozik. Mitől „jó” egy vezetés a demokrácia ezen felfogásában? Hogyan kell a vezetők és a követők kapcsolatát és szerepelosztását „helyesen” rendezni? Az alábbi fejezetben ezekre a kérdésekre keresem a választ.

\subsection{Az aggregatív-pluralista demokrácia alappremisszái}

A demokrácia aggregatív-pluralista elméletei a klasszikus képviseleti demokrácia koncepciójának modern olvasatát jelenítik meg (Pakulski-Körösényi 2013, pp. 88-93). Amíg a deliberatív-részvételi megközelítés föként morális elvárásokat fogalmaz meg, addig ez az elméleti keret materiális és procedurális leírását adja a demokráciának. Másképpen fogalmazva: itt a demokrácia elsősorban nem minőségi, hanem mennyiségi kérdés. A demokrácia e felfogása azon az alapgondolaton nyugszik, hogy a (demokratikus) politika természetéhez megkerülhetetlenül hozzátartozik a polgárok közötti egyenlőtlenség és az ebből fakadó érdekalapú konfliktus. A politika itt nem a deliberációt, hanem egy elosztási játékot jelent, ahol az a fó kérdés, hogy: „ki, mit, mikor és hogyan kap meg" (Lasswell). A politika nem a polgárok érvei, hanem az egyének érdekei, preferenciái körül forog. A demokratikus politika fő kérdése az, hogy az állampolgárok milyen módon képesek kontrollálni, befolyásolni az állam, a kormányzat müködését, a kormányzás tartalmát, amely elsősorban újraelosztási kérdésként jelenik meg. Ráfókuszálva: a központi probléma abban áll, hogy miként lesz a preferenciákból kormányprogram vagy közpolitika, illetőleg miként lesz az érdekekből hatalom vagy hatalmi tényező. Ennélfogva mind a preferenciák, mind a hatalom eloszlása kritikus a demokrácia müködése szempontjából.

A politika aggregatív és pluralista értelmezése két ellentétes irányból közelíti meg a modern képviseleti demokráciát. A pluralista felfogás (pl. Robert A. Dahl) „felülröl” tekint a demokráciára: a képviseleti demokrácia feltételeit, kereteit kívánja meghatározni, amelyben az állampolgári preferenciák és érdekek érvényesülhetnek bizonyos (érdek)szervezeteken keresztül. Középpontjában a különböző, egymással versengő érdekeket megjelenítő autonóm szervezetek állnak. Abból a gondolatból indul ki, hogy az egyének közötti preferenciális (motivációk, sérelmek) és értékítéletbéli (elfogadott normák, egyéni kötelezettségvállalások, hiedelmek és percepciók) különbségeknek a kormányzás mindegyik szintjén meg kell jelenniük. Dahl (1956, 1971) a ,poliarchia” (ógörög poly: sokak, arkhe: uralom) fogalmával ezt kívánja megragadni, amellyel lemond a demokrácia ideájáról és egy történetileg kialakult és így 
aktuálisan megvalósítható/megvalósítandó rezsimre fókuszál. Össze kívánja kötni az intézményeket és a procedúrákat a demokráciával szemben támasztott normatív elvárásokkal. A poliarchia karaktere a liberális, alkotmányos demokrácia intézményi konstellációját körvonalazza: választott tisztviselök, szabad és méltányos választások, egyenlő, passzív- és aktív választójog, szólásszabadság, alternatív információforrások és egyesületi autonómia. Ebben a keretben fontos a tényleges, effektív politikai részvétel, amely során az állampolgárok kifejezhetik a preferenciáikat, átláthatják a valódi alternatívákat és kontrollálhatják a kormányzást és a közpolitikát választott képviselőiken keresztül.

A közgazdaságtanból merítő aggregatív elméletek (pl. Anthony Downs) számára a demokrácia keretei eleve adottak, amelyek ilyen értelemben csak a játékszabályok összességét, a politika játékának a keretét jelentik. Az elméletek fókuszában a demokráciában megvalósuló politikai cselekvés áll, melynek alanyai a racionális, önérdekkövető egyének. A pluralista felfogással szemben az aggregatív elméletek minden esetben „alulról”, az aktorok felől közelítik meg a demokratikus politikát. Azzal a feltételezéssel élnek, hogy a demokratikus kormányzás viselkedési szabályait a racionális fogyasztók és termelök mintájára, egy (tökéletes) piaci analógiával le lehet írni. Az elmélet központi célkitüzése az, hogy megoldást találjon arra, hogy miként lesz az önérdekkövető polgárok és politikusok cselekvéséből közérdeket szolgáló politika. Ez jellemzi - Friedrich August von Hayek fogalmát használva - a „katalaxiát” (görög katalatto: cserélni) (Cunningham 2002, pp. 101-22), ahol a demokratikus politika spontán rendként alakul és épül fel, amelyet a politikai piac és a személytelen cserekapcsolatok hoztak létre bizonyos tartós szabályok között. Az elmélet logikájában a szélesebb részvételt követelő kollektív cselekvés irracionális (Olson 1971), amely lényegében explicit kritikája a pluralista felfogásnak is, mégis a politikai pártok közvetítő, aggregáló szerepe megkerülhetetlen a közérdek kialakításában.

Az ellentétet erősíti az elméletek fejlődése is. Amíg a dahli elmélet egyre nagyobb hangsúlyt fektetett a részvétel kérdésére (Krouse 1982) és a demokrácia morális oldalára (enlightened understanding: Dahl 1989; ld. erröl: Körösényi 2009c) - más szóval: a poliarchia empirikus, leíró igényű elmélete elsősorban normatívvá vált - addig a demokrácia gazdasági elméletében elötérbe került az eleve adott preferenciák változásának lehetősége (Hirschman 1970, 1985; Riker 1986), vagy épp a deliberatív demokrácia ideája felé való elmozdulás (Elster 1997). A poliarchia és katalaxia közötti nyilvánvaló hézagok ellenére mindkét megközelítés alacsonyabb morális elvárásokat 
fogalmaz meg a demokrácia deliberatív-részvételi felfogásánál, és egységesen a képviseleti demokrácia modern értelmezését adják. Az elkövetkezőkben az elmélet premisszáit tekintem át a politika bemeneti és kimeneti oldalára, valamint folyamatára fokuszálva.

Bemeneti oldal. A polgárok többé-kevésbé informáltak, viselkedésükben önérdekorientáltak, instrumentálisak és racionálisak. Az elmélet azzal a feltételezéssel él, hogy a polgárokat és a politikusokat egyaránt az önérdekük motiválja, amelynek csupán melléktermékei lehetnek a közjavak vagy a közérdek (self-interest axiom: Downs 1957, pp. 28-29, 1994, pp. 83-87). Ez persze nem jelenti azt, hogy az állampolgárok preferenciái nem vonatkozhatnak a közérdek tartalmára is (Downs 1962). A tudatos önérdekkövetés - Weber (1987, pp. 53-54) fogalmát használva - célracionalitást feltételez, ugyanis a cselekvés során az egyénnek gondosan kell mérlegelnie a célok és eszközök között, hogy hasznát maximalizálja, vagy épp költségeit minimalizálja.

Amíg az állampolgárok számára a kormányzat teljesítményérool, addig a politikusok számára az állampolgári preferenciákról való tájékozódás lehet irracionális (Downs 1957). Bár a racionális cselekvő csökkenteni kívánja a tájékozódással a bizonytalanságot azt illetően, hogy mi a legjobb céljai szempontjából, mégis el kívánja kerülni az informálódással járó költségeket. Ebből a szempontból felértékelődnek a politikai részvétel bizonyos formái, mint a lobbizás, az érdekszervezetek és a véleményvezérek tevékenysége, ugyanis azok információval szolgálhatnak a preferenciákról vagy a kormányzásról. A racionális informálatlanság azonban nem jelenti azt, hogy a polgárok ne lennének kompetensek, ugyanis a racionális önérdekkövetésből következik az a minimális elvárás, hogy képesek legyenek a preferenciáik rangsorolására és a személyes jólétük maximalizálására.

Az aggregatív-pluralista demokrácia alappremisszája az eleve adott (ex-ante), legalábbis tartalmát tekintve a politikai folyamaton kívül eső állampolgári preferenciák, amelyeket a polgárok elsősorban konvencionális eszközökkel fejeznek ki. Az állampolgári részvétel jelenti a politikai folyamat katalizátorát. A részvétel szélesítése és szintjének növelése azonban nem feltétlenül lehetséges és nem is szükséges. Egyfelől a politikai részvétel költséges és így irracionális (Downs 1957). A választónak regisztrálnia kell, tájékozódnia kell a jelöltekről, el kell mennie a szavazóhelyre és ki kell töltenie a szavazócédulát. Az idő értékes erőforrás és a szavazás elkerülhetetlenül költséges, amely effektíve nem is feltétlenül járul hozzá a végeredményhez. Egyeseknek előnyösebbnek, racionálisabbnak tünhet a politikai cselekvéstől, részvételtől való 
távolmaradás, hiszen az eredményes kollektív cselekvés esetében a közjavakból mindenki részesülni fog (potyautas stratégia: Olson 1971). ${ }^{34}$

Másfelől magasabb részvétel válságtünetként értelmezhető. Az állampolgárokat a kiábrándulás vezeti a politikától való elfordulás, azaz a magánéletbe való visszahúzódás irányába, illetve a politikai részvétel további formái felé (Hirschman 1985). A hirschmani változó elköteleződések (shifting involvements) a magán- és a politikai szféra közötti mozgást írják le, amely nagyobb időbeli távlatban hullámzó tendenciát láttathat. A kiábrándulást elsősorban külső tényezők váltják ki: például a javak, a szolgáltatások és a tevékenységek elégtelen színvonala, negatív irányú változása. Amíg a közoktatás, és/vagy az egészségügy minőségének romlása, vagy az elégtelen közpolitikai teljesítmény a politikai részvétel igényét erôsíti, addig a részvétel túlfokozott hevülete, az irreális politikai célok önmagukban hordozzák a kiábrándulást és a közéletből való kivonulás következményét. A képet azonban árnyalja Hirschman (1970) egy korábbi munkájának előhívása, melyben a politikai részvételt kivonulás, a tiltakozás és a hüség opcióiban határozta meg. Egy politikai botrány során, egy politikai kudarc után a választók kitarthatnak a preferenciáik mellett és továbbra is támogathatják az adott pártot (hüség opció). Lehetőségük van azonban másik pártot választani, vagy akár a politikától elfordulni (kivonulás opció) - itt lényegében a folyamat visszatér a hirschmani elköteleződés ciklusához -, de ki is nyilváníthatják véleményüket egy tüntetésen (tiltakozás opció). Furcsa helyzet áll így elő: az általánosan demokratikusnak tartott magas részvétel a rossz (kormányzati) politika következménye, s így az inkumbens, bevett politikai szereplőknek aligha füződik érdeke a részvétel növeléséhez.

Sőt, ennél messzebb lépve szükséges a magasabb politikai részvétel kontraproduktív jellegére is rámutatni. A dahli poliarchia ${ }^{35}$ két dolgot kíván meg az állampolgároktól: egyfelől az alapelveinek az elfogadását, másfelől a politikai aktivitást. Azonban a demokrácia müködéséhez elégségesnek bizonyul a részvétel alacsonyabb szintje is (Dahl 1956), ugyanis a túlságosan kiterjedt politikai részvétel - a totaliter rendszerek tapasztalatából kiindulva - erodálhatja az intézmények körül kialakult bizalmat és konszenzust. A démoszt tehát egyszerre kell hatástalanítani, s így megvédeni a

\footnotetext{
${ }^{34}$ Érdekes, hogy a kötet sikere ellenére nem tudta kora változásait megmagyarázni. Ugyanis a könyv (első) megjelenése (1963) épp arra az időszakra esett, amikor a felfutó állampolgári részvétel és a politikai mobilizáció egy újabb hulláma határozta meg a politikát (polgárjogi mozgalmak, hippimozgalmak, diáktüntetések, prágai tavasz), melyet Albert O. Hirschman (1970, p. 30) egyenesen a tiltakozás korának írt le.

${ }^{35}$ Fontos megjegyezni, hogy Dahl elméletének továbbgondolása során egyre nagyobb szerepet szán a politikai részvételnek (Krouse 1982), amely elméletének normatív fordulatával még szembetünőbb (Dahl 1989; ld. erről Cunningham 2002, pp. 87-90.). Ennek, és az általa az aggregatív elméleti értelmezéssel szemben kirajzolt kontrasztnak a részletezésére azonban itt nincs mód.
} 
demokratikus intézményeket, illetőleg ösztönözni a politikai aktivitásra, azaz a részvételre és a preferenciák kinyilvánítására tényleges és effektív lehetőséget biztosítani.

Összességében tehát a preferenciákat kifejező konvencionális részvétel (pl. a szavazás, a lobbitevékenység és az érdekszervezetek) jelentősége megkérdőjelezhetetlen, ugyanis az indítja el a politikai folyamatot, és jelent egyfajta információforrást is az érdekeket és preferenciákat illetően. Azonban az ezen túlmenő nem konvencionális, szélesebb állampolgári politikai jelenlét gyanúval kezelendő az elmélet perspektívájából kiindulva.

A politika folyamata. Ebben a keretben a politikai folyamat alulról fölfelé (bottom-up) épülve az egyéni preferenciák, érdekek és a népakaratot leírni kívánó közpolitika összekapcsolásában áll. Ez a folyamat a reszponzivitás (Dahl 1971, pp. 1-2) normatív elvárása köré épül, amely két szakaszra bontható: (1) a pártok versenye által megszabott preferencia-aggregáció és (2) a döntéshozatalt meghatározó érdek- és preferenciaképviselet szakaszára. Amíg az első szakasz elsősorban a választók és a pártok, jelöltek kapcsolatára mutat rá, addig a második a visszacsatolást emeli ki, azaz a kormány, inkumbens párt és a választók viszonyát. A két szakasz a választás pillanatában kapcsolódik össze, ahol a pártok feltételezései a preferenciákról, valamint döntései igazolást nyerhetnek, illetőleg a kormányzás egyfajta irányvonalat kap.

A politikai folyamat első szakasza a preferenciák aggregációja, amelyet a pártok versengő magatartása határoz meg. A pártok és jelöltek a gazdaság szereplőihez hasonlóan cselekednek, és úgy határozzák meg a pozíciójukat a választási versenyben, hogy a megszerezhető szavazatokat maximalizálják. Másképpen fogalmazva: a pártok azt remélik, hogy a „termékük” - programjuk, ígéreteik, ideológiájuk - elnyeri a választók többségének a tetszését. Kulcsfontosságú tehát az, hogy a politikusok mennyire preferenciaérzékenyek, azaz mennyire tudják követni a mindenkori közvéleményt. A másik oldalról megközelítve: a szavazók annak alapján választanak pártot, hogy az mennyire áll hozzájuk közel kulcskérdésekben. A választáskor nem válik el a cselekvő (a jelölt, a párt) és az általa képviselt ügyek (a program, az ideológia). Azaz: a választás során a polgárok egyszerre döntenek az ügyekről és a jelöltekről (Dahl és Lindblom 1953, pp. 69-71).

A folyamat második szakasza a preferenciákra reszponzív érdekképviselet. A folyamat ezen része abban az elvárásban ragadható meg, hogy a közjó a választók akaratában megnyilvánuló népakaratnak megfelelö reszponzív közpolitika érvényesítése révén 
érhető el. Túl ezen a normatív elváráson, a kormányzó pártokat mozgató logikára az ún. Friedrich-törvény (Körösényi 2006, 2007) mutat rá. Ennek értelmében a kormányon levő és újraválasztásukra törekvő pártok, politikusok igyekeznek a jövőbeli állampolgári ítéletek szerint alakítani a politikájukat, hogy azzal növeljék az újraválasztásuk esélyeit. Összességében az inkumbens pártoknak össze kell hangolniuk a kormányzati funkciók (adógyüjtés, közszolgáltatások fenntartása) ellátását az elégséges mennyiségű szavazói igény kielégítésével.

A pártok hatalomért, és az újraválasztásért folyó küzdelmének csak melléktermékét jelenti a közérdek és a közjó, ahogyan azt Downs „önérdek axiómája” is aláhúzza. A hivatal-orientált pártok, politikusok versengenek a választásokon a szavazatokért, mégpedig elsősorban nem szakpolitikák implementálásért küzdenek, hanem a hivatalból fakadó jövedelemért vagy hatalomért. Ehhez hozzájárul az is, hogy nem létezik objektív tudás sem az egyéni önérdekre, sem a közérdekre mutató preferenciákat illetően. A pártok, az inkumbens politikusok csupán próbálják eltalálni azt a programot, amely a legközelebb áll a többség akaratához (Downs 1962). A közérdek, a népakarat egy „üres tér” (Cunningham 2002, pp. 64-65), amelyben a politikusok azt teszik, amiről úgy vélik, hogy az megfelel a közérdeknek. A közérdek ugyan nem adódik egyértelmüen és közvetlenül a politikai folyamat során összegzett preferenciákból, mégis a megkapott mandátum és az anticipált állampolgári preferenciák és ítéletek információval töltik meg a politikai folyamatot. Ilyen értelemben az állampolgárok prospektív és/vagy retrospektív módon képesek irányt szabni a politikai folyamatnak ${ }^{36}$

Kimeneti oldal. Az elmélet szempontjából kulcsfontosságú a szavazás intézménye. Az önérdek által mozgatott politika célja nem egy minél szélesebb konszenzus, hanem egy minimális kiterjedésü, de elégséges kompromisszum kialakítása. Ez alatt egy olyan egyensúlyi állapot, optimális helyzet érthető, amelyet az adott feltételek között senkinek (vagy legalábbis a többségnek) nem érdeke megváltoztatni. Tartalmát tekintve a kompromisszum a vélt, és szavazás által elfogadott többségi akaratot jelöli. Rugalmasságát és dinamikáját a versengő, konfrontálódó érdekek állandó harmonizációjának a kényszere teremti meg, amely az előzőekben a politikai folyamat preferencia-aggregáló szakaszában fogható meg. A kompromisszumot tehát a szavazás intézménye hozza létre és szentesíti, amelynél fogva a szerepe kritikus.

\footnotetext{
${ }^{36}$ Lásd az elszámoltatás- és mandátumelméletről Körösényi $(2006,2007)$ munkáit. Az elméletek és azok közötti ellentét részletezésre ehelyütt nincs mód.
} 
A szavazás jelentősége azonban nem merül ki a preferenciák összegzésében és az érdekek harmonizációjában, ugyanis a többségi döntés kitétele révén a kisebbség zsarnoksága is elkerülhető általa. Fontos azonban itt megjegyezni, hogy ez a kompromisszum nem csak a különböző érdekek és preferenciák összeegyeztetésében áll, hanem a választók és politikusok közötti egyezségre és a közérdek érvényesülését szolgáló procedúrák és intézmények elfogadására és tiszteletére is ki kell terjednie. Ennek jelentősége abban áll, hogy a demokratikus intézményi és procedurális környezet - például a rendszeres választásokon létrejövő többség ciklikussága, a hatalommegosztás és a kikerülhetetlen érdekpluralizmus révén -tudja a többségi zsarnokság veszélyét kizárni.

\subsection{Az aggregatív-pluralista demokrácia implicit vezetéselmélete}

Az aggregatív-pluralista demokráciaelmélet explicitebben számol a politikai vezetéssel (Downs 1957, pp. 87-88, 1962, pp. 33-36; Keohane 2015; McFarland 1969; Olson 1971, pp. 174-78) ${ }^{37}$, mint a deliberatív-részvételi demokráciaelmélet. Ugyanakkor a vezetés szerepe ambivalens: egyszerre szükséges és korlátozandó. A politikai részvételhez, cselekvéshez szükséges források (az idő vagy a tudás) egyenlőtlenül oszlanak el a politikai cselekvők között, amelyből az következik, hogy egyeseknek nagyobb befolyásuk van a döntésekre (Dahl 1961; Downs 1957, pp. 87-88). Ebből következően: egyik oldalról Olson (1971, pp. 174-78) elengedhetetlennek tartja a kollektív cselekvés megvalósulásához a vezetést, míg másik oldalról megközelítve Dahl (1956, p. 3) demokráciaelmélete egyenesen arra a problémára épül, miképpen tudnak az állampolgárok kontrollt gyakorolni vezetőik felett. S bár Dahl sosem alkotott koherens vezetéselméletet, mégis központi elem maradt munkáiban (Keohane 2015), mint ami természetesen szükséges, de amit korlátok közé is kell szorítani a poliarchia kereteiben. Mindazonáltal Andrew McFarland (1969) expliciten Dahl (1961) politika képére építve a vezetés szerepét hangsúlyozza a pluralista demokráciában. A pluralista politikust szembeállítja a karizmatikus hőssel, aki a konfliktusok feloldását és a közérdek állandó „frissítését” látja el. Látni kell azonban, hogy az alapprobléma - ahogy Downs (1962, p. 36) fogalmaz - abban áll, hogy a demokrácia nem engedheti meg magának, hogy feláldozza a reszponzív kormányzást egy hatékonyabb, kreatívabb vezetés érdekében. A vezetőket tehát úgy, és olyan mértékben kell hatalommal felruházni a közös ügyek

${ }^{37}$ Itt kell megjegyezni, hogy Olson és Downs csak a későbbi munkáiban (Olson 1971, pp. 174-178) helyeztek nagyobb hangsúlyt a vezetésre. 
rendezéséhez, azaz a politika kihívásainak leküzdéséhez, hogy azzal ne vezessék ki a közösséget a demokratikus keretek közül.

Összességében a következő pontokban kapcsolódnak e munkák vezetésképükben:

- A jó vezetés kulcsát a demokratikus keretek tiszteletben tartásában és a közérdek érvényesítésében kell keresni. A vezetés előtt a mérce az lesz, hogy mennyiben sikerül a demokrácia játékszabályainak megfelelően elérni a vezetők elé kitűzött feladatokat. Fontos aláhúzni, hogy a politikai vezetés itt nem monopólium, az megoszlik a társadalomban és bizonyos intézményekhez kötődik, amelyekhez kapcsolódó értékek és célok korlátozzák.

- A vezetés célját a szükséges politikai részvétel (kollektív cselekvés) biztosítása és a közérdek, valamint az azon alapuló politika kialakításának elősegítése jelenti.

- A vezetők olyan technikai tudással rendelkeznek, amely kizárólag vezetés céljait szolgáló eszközök, procedúrák ismeretére és használatára vonatkozik.

- A vezetők és követők közötti érdekalapú kapcsolódást egyfajta piaci jellegü csere határozza meg. A kapcsolat hierarchikus és a szereplök kölcsönösen függenek egymástól.

Az elkövetkezőkben e pontokra alapozva bontom ki az aggregatív-pluralista demokrácia implicit vezetéselméletét.

\subsubsection{A,jó" vezetés}

A politikai folyamat piaci analógiájából és az önérdekkövető, (cél)racionális politikai cselekvésből következően a vezetés a követők és a vezetők közötti „,piaci” cserében fogható meg. A vezetés e felfogását tranzaktív vezetésnek (transactional leadership: Burns 1978; Downton 1973) nevezik ${ }^{38}$, amelyben egy, a gazdasági élet szerződéses kapcsolataival analóg és a résztvevők jóhiszemüségére alapozott csere- és alkudozási folyamat írható le. Ezeket a „kapcsolatokat gyors költség-haszon kalkulációk dominálják.” (Burns 1978, p. 258) A tranzaktív vezetés lényege abban merül ki, hogy a felek kölcsönösen kedvező, elsősorban pragmatista megállapodásra, kompromisszumra törekednek. A vezetők és a követők önérdekei, céljai, szándékai összekapcsolódnak, de nem szükségképpen azonosak. A vezető ad, és cserébe kér is valamit: munkahelyeket szavazatokért, állami szubvenciót kampány-hozzájárulásért. Mindkét fél bár kölcsönösen függ a másiktól, mégis a kapcsolatuk csak addig tart, amíg az egyéni

\footnotetext{
${ }^{38}$ A vezetés e formáját, melyet Downton (1973) fogalmaz meg először, Burns (1978) a transzformatív vezetés párjaként emeli be a szélesebb tudományos diskurzusba.
} 
érdekek tükröződnek a vezető által felmutatott közérdek képében, azaz: a követők azt kapják, amit szeretnének.

Fontos aláhúzni, hogy a vezetés itt sem mentesül a morális elvárásoktól, amelyeken a vezetők és követők közötti cserekapcsolatához szükséges kölcsönös bizalom is nyugszik. Dahl (1956) és Downs (1962) értelmezése szerint a politikai cselekvés legitimitásának a procedúrák és intézmények tiszteletben tartásán kell nyugodnia. Másképpen fogalmazva: az aggregatív-pluralista demokrácia normatív elvárásainak a hordozói - és a vezetés korlátai - maguk az intézmények, valamint az általuk becsatornázott és létrehozott közérdek. A tranzaktív vezetésben rejlő bizalmi kapcsolatot az eszközöket, intézményeket és procedúrákat érintő, „modális” értékek, mint az őszinteség, a méltányosság, a felelősség, vagy az egyéni elköteleződések tisztelete biztosítja, amelyekhez a vezetőknek igazodniuk kell (Burns 1978, p. 426). ${ }^{39}$ A vezetésnek tehát formális pozícióhoz, hatáskörhöz, intézményhez, s nem az adott személyhez kell kötődnie. Ebből kifolyólag válik morális jelentőségűvé a politikusok célracionalitása, hivatal-orientáltsága.

Ezt egészíti ki az a gondolat, hogy a politikai intézmények és versengő politikai szereplők pluralizmusából fakadóan a vezetés funkciója szükségszerűen megoszlik a társadalomban. Azaz: a vezetés nem egy uralkodó elitben, vagy egy uralkodóban, egy zsarnokban koncentrálódik, hanem az széles körben szétoszlik (dispersed leadership: Kane, Patapan, és 't Hart 2009). A tranzaktív vezetés tehát semmiképp sem lehet monopólium (Dahl 1961, pp. 101-2; Downs 1962, p. 36). Összességében a vezetést egyszerre köti az, hogy tiszteletben kell tartania a demokratikus intézményi környezetet, valamint a pluralizmus alapját jelentő a csoportos érdekeket és az egyéni preferenciákat. Ezzel a vezetés tökéletesen és maradéktalanul teljesítheti a weberi felelősségetika kitételét (M. Weber 1989, pp. 74-75): az intézményi keretek, procedúrák, és maguk az állampolgárok - külső tényezőként - kikényszerítik a vezetőtől cselekvése következményeivel való elszámolást és a felelősségvállalást, s így a reszponzivitást és a Fridrich-törvény beteljesülését.

A tranzaktív vezetés előtt a legfőbb kihívás a „politikacsinálás”, amely az egyéni preferenciák, érdekek és a népakaratot megtestesítő kormányzás összekapcsolását jelenti (1. szempont). Ezt két mozzanatban lehet megfogni. Egyfelől a vezetésnek a

\footnotetext{
39 Az előző alfejezetben tárgyalt demokratikus vezetés-koncepcióhoz viszonyítva Burns lényegében alacsonyabb szintre helyezi a vezetés morális alapjait, elvégre már nem a vezető és tevékenysége számít az értékek forrásának, hanem az őt körülvevő intézmények és procedúrák számítanak értékesnek azáltal, hogy korlátokat szabnak. Ezzel impliciten, némiképp diszkreditálja a vezetés ezen formáját: először tudatosan szembeállítja a transzformatív vezetéssel (Burns 1978), majd túl is lép azon (Burns 2003).
} 
közjavak létrehozása, a preferenciák kifejezése céljából fenn kell tartania a kellő állampolgári részvételt, azaz a kollektív cselekvést. Másfelől a vezetésnek ki kell alakítania a közérdeket, a közakaratot. Pontosabban fogalmazva: ki kell töltenie a közérdek ,üres terét”, s a korlátozott informáltság világában el kell találnia a választók önmagukra és a közérdekre vonatkoztatott preferenciáit.

Az első mozzanat a kollektív cselekvés (politikai részvétel) fenntartása. A kollektív cselekvés, az állampolgári részvétel egy bizonyos mértéke szükséges a demokrácia fenntartásához és a preferenciák tartalmának és változásának kifejezéséhez, felméréséhez. Mancur Olson (1971) „A kollektív cselekvés logikája” (The Logic of Collective Action) címü könyvében az ennek gátat szabó kollektív cselekvés problémáját tárja fel, amely szerint racionális döntés a közös cselekvéstől, a közjavak létrehozásától való távolmaradás, a potyautas stratégia. Olson eredeti, 1965-ös mủvének második kiadásához mellékelt esszéjében (Olson 1971, pp. 174-78) kiemeli a „politikai vállalkozó” szerepét, aki képes előteremteni - akár egymaga is - a kollektív javakat. Így ő válik a kollektív cselekvés kulcsává és motorjává (ld. erről: Boda 2013). A vezető mind a kis-, mind a nagy (látens) csoportokban - alkudozás révén alakít ki a költségek megosztásáról egy megállapodást, amellyel a közjavak optimális mértékben történő biztosítását célozza meg.

„Ez azt jelenti, hogy a vezető, vagy vállalkozó; akiben általában megbíznak (vagy akitől félnek, aki tudja, hogy ki blöfföl egy alkuszituációban, aki szimplán képes időt megtakarítani az alkudozás folyamán), az képes néha olyan megállapodást kidolgozni, amely minden érintett számára jobb, mint bármely olyan eredmény, amely a vállalkozói vezetés vagy -szervezet hiányában alakult volna ki.” (ford. tőlem) (Olson 1971, p. 176)

Azonban a nagyobb csoportok esetében szinte lehetetlen optimális mértékben, mennyiségben biztosítani a kollektív javakat (ha egyáltalán lehetséges). A vezető itt szelektív ösztönzőkkel - kényszerrel és jutalmazással - bírhatja rá az érintetteket, hogy járuljanak hozzá a csoport erőfeszítéseihez. A vezetőnek megéri átvállalni a költségek egy részét, s szelektív ösztönzőkkel kikényszeríteni a kollektív cselekvést, ugyanis számára a befektetett költségek fényében a kollektív cselekvés nagyobb haszonnal jár. Sőt a nagyobb csoportoknál abból fakadóan, hogy az optimálistól való eltérés elkerülhetetlen és a bevont emberek száma is sokkal magasabb, a csoport szervezése és a kollektív javak biztosítása is sokkal nagyobb haszonnal jár. Ezért a „képzeletbeli vállalkozók” erőteljesen megküzdenek azért, hogy nagyobb csoportokat szervezzenek. 
Ebben a folyamatban a vezetőknek szükségszerü találni, vagy akár kreálni olyan szelektív ösztönzőket, amelyek képesek támogatni a közjavak biztosítását, a politikai részvételt. Olson (1971, p. 177) konklúziója szerint a vezetőknek a szelektív ösztönzők innovátorává kell válniuk ahhoz, hogy sikeresek legyenek. A tranzaktív vezetés elsősorban a szelektív ösztönzők eszköztárára épít. Downton (1973) például megkülönbözteti a pozitív, jutalmazó, és a negatív, büntető tranzakciókat, amelyek egyszerre határozzák meg az alkudozás folyamatát a haszonmaximalizáló vezetők és a követök között. Ezek kemény hatalmi eszközök (stick-and-carrots, hard power: Nye 2008). Ezekre támaszkodva a vezetőknek - szervezési kapacitásuk függvényében képesnek kell lenniük a jutalmazási és büntetési mechanizmusokat és az információs rendszert menedzselni (Nye 2008, pp. 77-80). Ugyancsak szükségesnek tünik, hogy rendelkezzenek bizonyos machiavelliánusi erényekkel, amelyekkel akaratukat keresztül tudják vinni az alku- és csereszituációkon, illetőleg ki tudnak alakítani, és fenn tudnak tartani egy győztes koalíciót (Nye 2008, pp. 80-84). Az alkudozás, a büntetés és jutalmazás interakciói a különböző szereplők közötti intézményesített csatornákon keresztül zajlanak. Ezen a ponton a tranzaktív vezetés hatékonysága azon nyugszik, hogy képes-e a vezető használni a szelektív ösztönzőket és egyensúlyt kialakítani a büntetés és a jutalmazás interakciói között.

Mindebből három dolgot fontos leszürni. Egyrészt a kemény eszközök használata nem jelenti azt, hogy a vezető cselekvése nyers hatalomgyakorláson, parancsoláson alapul, sokkal inkább alkudozáson, önkéntes piaci jellegű meggyőzésen. Másrészt a vezető itt közvetlenül csak mobilizál, meglévő (ex-ante) preferenciák kinyilvánítására buzdít, a politika bottom-up irányú folyamatát segíti elö, s nem a preferenciák tartalmát befolyásolja. Harmadrészt nem szabad elfelejteni, hogy az elmélet szemszögéböl a politikai részvétel egyszerre információforrás és a szavazatok formájában erőforrás is. Ezért a politikai vezetésnek azt is figyelembe kell vennie, hogy mi számít jó, és mi rossz politikai részvételnek, gondolva a korábban részletezett hirschmani kivonulástiltakozás-hüség lehetőségeire.

A második mozzanat a közérdek tartalmának a meghatározása az állampolgári preferenciákra alapozva. A vezetőnek nemcsak mobilizálnia kell „vásárlóit”, de „politikai terméket” is létre kell hoznia, amellyel lényegében újra és újra „frissíti”, „aktualizálja” a közérdeket (Downs 1962; McFarland 1969). Ennek a jelentősége abban áll, hogy a többség kialakítására törekedve a vezetők közvetítenek a sokrétü csoportérdekek között, és a konfliktusokat fel is oldják: közös nevezőre hozzák az 
érdekeket, kompromisszumot alakítanak ki. Mindezt három tényező határozza meg: a (1) hiányos informáltság a preferenciákról, az (2) önérdekkövető politikai szereplők és a (3) preferenciák eleve adott természete.

A hiányos informáltság (1) világában, ahogy a hivatal-orientált politikusok sincsenek teljesen tisztában a választók közérdekröl és önérdekükről alkotott preferenciáival, úgy az állampolgárok sem tudnak pontos képet alkotni a politikai szereplők tevékenységéről, és arról, hogy az miképpen járul hozzá érdekeik kielégítéséhez. Ennek leküzdése mindkét félnek költséges, amely még az információforrások - pl. a lobbi- és érdekszervezetek, a véleményvezérek tevékenységének - becsatornázása mellett is állandósítja a racionális tájékozatlanságot (Downs 1957). A kollektív cselekvés fenntartása arra mutat rá, hogy a vezetőknek érdekükben áll tájékozódni a választói preferenciákról, és vállalni az ezzel járó költségeket annak érdekében, hogy szavazataikat elnyerjék. Ennek ellenére a választások során összegződött egyéni preferenciák sem jelenthetnek biztos kapaszkodót, ugyanis - miként a szavazási paradoxonok (Körösényi 2009b) rámutatnak - nem képesek meghatározni kielégítően a népakaratot. A közérdek nem egyértelműen és közvetlenül következik a politikai folyamat során összegzett preferenciákból. Annak tartalmáról a döntéshozók csak feltételezésekkel rendelkezhetnek, amelyek vagy találkoznak az állampolgárok erről alkotott elképzeléseivel, vagy nem. A közérdek ennélfogva egy „üres tér” (Cunningham 2002, pp. 64-65), amelyben a vezetők azt teszik, amiről úgy vélik, hogy az megfelel a közérdeknek. Más szavakkal: a politikus közérdek-képe azt a közpolitikát jeleníti meg, amelyről úgy gondolja, hogy a választók ilyen irányú preferenciáihoz közel áll (Downs 1962).

Ugyancsak fontos látni azt a tényezőt, amelyet Downs (1957, pp. 28-29, 1994, pp. 8387) az önérdek axiómájának (2) nevezett. A vezető cselekvését elsősorban önérdeke határozza meg, amelynek módosítása, követőkéhez igazítása költséges. Másik oldalról megközelítve: a potyautasság a vezetőkre is igaz lehet, ugyanis adott esetben ők is kereshetik a kiskaput annak érdekében, hogy a hasznukat maximalizálják. A közjó ebben az értelemben a vezető önérdekü cselekvésének mellékterméke (Cunningham 2002, pp. 103-4). Downs (1962, p. 25) számára a közérdek, mint politikai termék, részben azonos a politikai ideológiával, ami korábbi munkájában (Downs 1957) kulcsszerepet kapott az informáltság növelésében. Ennek fényében a vezetök nem azért formálnak koncepciókat (ideológiát, programot) arról, hogy mit kellene tenniük, mert azt valóban, feltétlenül meg is szeretnék valósítani; hanem azért, mert úgy gondolják, 
hogy az kedvezni fog a választóiknak. Ez azt is jelenti, hogy bár a közérdek alatt az egész társadalomnak hasznos kormányzati akciók összességét szokás érteni, a downsi logikát követve a megfogalmazott közérdek mégsem terjedhet ki „,mindenkire”, ugyanis az túl költséges lenne, és túlságosan megkötné a reszponzív politikusok kezét. Sőt az elmélet számára normatív értelemben nem is kívánatos, de nem is szükséges egy átfogó konszenzus a közérdekről, hiszen az végeredményben ellentmondana a pluralizmus kívánalmának.

Az utolsó tényező, amit számításba kell venni, az az állampolgárok preferenciái (3), mint külső, exogén adottság. A vezetők közvetlenül nem a választói preferenciákat befolyásolják, hanem csak az azok kielégítéséhez szükséges legjobb közpolitikákról kívánják meggyőzni a szavazók többségét (Downs 1957, p. 87). Másszóval: annak érdekében, hogy a politikusok megszerezzék, vagy épp megtartsák a közhivatalt, szükségszerü meggyőzniük a választók többségét politikájuk, döntéseik helyességről; pontosabban arról, hogy az a közérdekre irányul. Downs (1962, pp. 16-17) három szcenáriót vázol fel. Először is a vezető nem kívánja meggyőzni a választókat, nem kíván a preferenciákkal konzisztens politikát folytatni. Ebben az esetben a választók egyszerüen felismerik a rossz közpolitikát és azért a vezetőt teszik felelőssé. A második forgatókönyv szerint a vezető továbbra sem próbálja meggyőzni a választókat, de igyekszik olyan politikát érvényesíteni, amelyről úgy gondolja, hogy a közérdeknek megfelel. Ez a kurzus magában rejti azt a veszélyt, hogy a választók többsége nem ismeri fel saját érdekét, és az alkalmazott politikát úgy interpretálja, hogy a meghozott döntések ellenük irányulnak és ezért a vezetőt hibáztatják. Végül a harmadik lehetőség az, ha a vezető igyekszik meggyőzni a választókat arról, hogy az általa nyújtott politika a legjobb számukra. Természetesen itt is jelen van annak az esélye, hogy a rossz döntések miatt elszámoltatják a vezetőt, de a vezető meg is győzheti a választókat a politikája helyességéről. Lényegében Downs a vezetés fő funkcióját abban látja, hogy a hatalomért küzdő vezetők igyekeznek a választói igényeket összeegyeztetni a politikájukkal és fordítva, politikájukat a választói igényekkel.

A preferenciák közvetett módon történő befolyásolására egy másik lehetőség is adott, amelyre William H. Riker (1986; ld. erről: Körösényi 2009a, 2009b; McLean 2002) mutatott rá a heresztetika, mint politikai manipuláció müvészete, fogalmának a

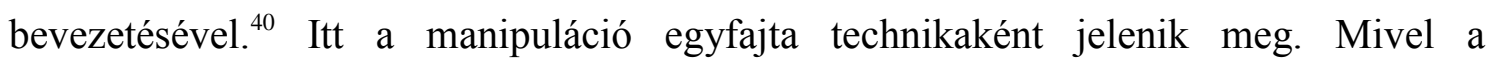

\footnotetext{
${ }^{40}$ Riker megközelítését ebben az elméleti keretben értelmezem, noha az a vezérdemokrácia keretébe is helyezhető (vö. Körösényi 2009a, 2009b, 2010). Tarthatónak tünik a heresztetika radikális olvasata, amelyben valóban úgy tünhet, hogy a megítélés dimenziójának, mércéjének megváltoztatása (változó
} 
preferenciák közvetlen, tartalmi manipulációja (retorika) logikailag nem lehetséges ebben az elméleti keretben, ezért a vezetők közvetett módon a politikai, választási helyzetek strukturálása, stratégiai manipulációja (heresztetika) révén tudják befolyásolni azok eloszlását. Ilyen olvasatban a heresztetika csupán „terelheti” a preferenciákat és nem megalkotja azokat. Riker a heresztetika három fö típusát különbözteti meg:

(1) Napirend-formálás. Az eddigiekben amellett érveltem, hogy a közérdeknek nincs biztos, objektív alapja. A jelöltek ,találgatnak” azt illetően, hogy milyen ügyek kerüljenek a pártprogramokba, és azokra milyen fontossági hangsúly kerüljön. A választásokon megjelenő szubjektív jellegü preferenciák, és azok aggregációja nem jelentenek megkérdőjelezhetetlen alapot a program- és politikaalkotáshoz. Ennélfogva a politikai napirend (is) a politikai verseny színterévé válik. Fontos lesz, hogy melyik kérdés válik politikai üggyé, vagy épp a riválisok milyen ügyeket emelnek be a napirendbe. A napirend-formálás ilyen értelemben azon ügyek meghatározására vonatkozik, amelyek a politikai diskurzus vagy a döntéshozatal napirendjére kerülnek. Értelemszerüen a pártok és a jelöltek olyan ügyeket, alternatívákat támogatnak, hangsúlyoznak, amelyek a szavazatmaximalizáció szempontjából hasznos számukra. Ugyanakkor fontos kiemelni, hogy az aggregatív-pluralista demokrácia keretében a napirendformálás sohasem egyoldalú tevékenység, hiszen az nagyban múlik a pártok, politikusok versenyén és a polgárok eleve adott preferenciáin. Így egyaránt kritikus, hogy az adott politikai szereplő milyen stratégiai célokat tűz ki a tematizálásban; a riválisai milyen ügyeket preferálnak; vagy épp a napirendformálás, az új ügyek illeszkednek-e a polgárok preferenciáihoz.

(2) A megítélés dimenzióinak megváltoztatása. A politikai szereplők közvetett módon ugyancsak manipulálhatják a preferenciákat, amennyiben egy-egy helyzetet vagy ügyet újradefiniálnak; pontosabban, ha az adott ügy megítélésének dimenzióját, szempontjait megváltoztatják. A vezetők nem csak új ügyeket, vagy azokra vonatkozó döntési alternatívákat vezethetnek be, hanem már adott ügyeket, opciókat is új megvilágításba helyezhetnek. Mindezzel a választók preferenciái oly módon rendeződhetnek át, hogy az eddig támogatott politikát az új megítélési szempont fényében átértékelik.

\footnotetext{
kalkulus) egyoldalú és a preferenciákat endogén módon befolyásolja (Körösényi 2010). Nézőpontomból a racionális cselekvők, vezetők kezébe helyezett heresztetika a politikai küzdelem olyan bevett eszköze, amely bár némiképp továbbgondolja (preferenciák változtathatósága), de illeszkedik is az aggregatívpluralista demokrácia alappremisszáihoz (preferenciák eleve adott jellege).
} 
(3) Stratégiai szavazás. A szavazók esetében erősen feltételezhető, hogy nem őszintén nyilvánítják ki a preferenciáikat, hanem stratégiai módon szavaznak. Ezzel a preferenciájukhoz közelebb álló, optimálisabb eredményt tudnak elérni. A stratégiai szavazás lehetőséget ad a vezetőknek, hogy a választási procedúrák befolyásolásával megváltoztathassák a preferenciák eloszlását.

Fontos azonban itt látni, hogy az elmélet keretében a heresztetika, mint eszköz, korlátozott és nem egyirányú, nem egyoldalú folyamat. Az intézményes (például a szavazási eljárást érintő) és a napirendet illető változásokat egyaránt korlátozza a politikai szereplők versenye, és más formális vétójátékos. Az egymással szembehelyezkedő érdekek kiolthatják a heurisztika stratégiáját: az új ügyeket, döntési alternatívákat marginalizálni lehet, ha új értelmezési keretet adnak számukra, viszont az új értelmezési dimenziókat ki lehet zárni a politikai napirend diskurzusából, illetőleg a szavazási eljárás változtatásának intézményi korlátai is lehetnek. A heurisztikának valamilyen vezetők közötti együttmüködésen kell alapulnia ahhoz, hogy mélyebb és látványosabb változást hozzon. S még ha a politikai vezetők széles köre egységes cselekvőként lépne is $\mathrm{fel}^{41}$, a preferenciákat akkor is csak közvetlen módon képesek befolyásolni. Sőt a preferenciáktól való effektív függés, és az azokkal kapcsolatos általános információhiány komoly kockázatot rejt magában a politikai innovációt és kísérletezést illető vállalkozások előtt. Azzal, hogy megadott időközönként a választóknak lehetőségük van megválasztani vagy elutasítani vezetőiket, illetőleg a szükséges információkhoz való hozzáférés nem korlátozott, a végső kontroll továbbra is a kezükben van például a politikai napirend felett. A vezetők a politikai helyzet cselekvéstől közvetlenül függő, strukturális elemein keresztül tudják befolyásolni az állampolgárok preferenciáit. S ezzel esetlegessé válik annak eredménye is. Lényegében a heurisztika a meglévő politikai keretekben, rendszerben rejlö rugalmasság kihasználására mutat rá, amellyel a preferenciák eloszlásának „finomhangolását” lehet elvégezni.

Összességében a tranzaktív vezetés igen széles eszköztárral rendelkezik: szelektív ösztönzők (Olson 1971, p. 177), „kemény” hatalmi eszközök (Burns 1978; Downton 1973; Nye 2008), a konfliktusokat meghaladó közérdek, mint politikai termék (Downs 1962; McFarland 1969), valamint a heresztetika (Körösényi 2009a, 2009b; Riker 1986). Ezekkel az eszközökkel a vezető mesteremberként valami rajta kívül álló dologból (preferenciákból) egy másik tőle független dolgot (közérdeket) hoz létre. Azzal, hogy az

${ }^{41}$ Lásd például Katz és Mair (1995) kartellpárt tézisét. 
intézményi környezet és procedúrák adottak, a vezető „gépészként” üzemelteti a politika gépezetét. A vezető ezzel mégsem válik feleslegessé: a meglévő mechanizmusokon keresztül ő gyártja le a közérdeket, valamint indítja be, finomhangolja, és az intézmények tiszteletben tartásával, status quo- és feladatorientáltságával tartja karban a politikát. Itt a megfelelő eszközök kiválasztása és alkalmazása elsősorban technikai problémát jelent. A vezetés előtt álló kihívásokhoz elsősorban technikai vagy produktív tudásra (tekhné) (Körösényi 2005, pp. 232-33) van szükség (2. szempont). A célracionális vezetőnek képesnek kell lennie arra, hogy egy képzeletbeli „útmutató” alapján válasszon ki és használjon egy megfelelő eszközt céljai eléréséhez. S bár kompetens „szakértő” menedzserként jelenik meg követői előtt, hisz ismeri a politika müködését, mégsem technokrata, ugyanis döntéseiben törekednie kell az intézményekben (pl. alkotmány, választások, szabadságjogok) megtestesülő morális elvárásoknak és az állampolgári preferenciáknak való megfelelésre. Így tevékenységének önmagán kívüli végeredményéért felelősséget kell és tud is vállalni (felelősségetika), pontosabban azért, hogy megfelelően „müködik-e” a politika, tudja-e mobilizálni a választóit, és képes volt-e politikai terméket létrehozni.

\subsubsection{A „helyes” kapcsolat a vezetők és a követők között}

Mivel az aggregatív-pluralista demokrácia nagy hangsúlyt helyez az önérdek-orientált, racionális, kompetens és korlátozottan informált állampolgárokra és a bottom-up politikai folyamatra, a követőkre is aktív és meghatározó szerep hárul. Mindazonáltal a vezetők és a követők kapcsolatát egyfajta kettősség jellemzi (Dahl 1961; Downs 1962). Bár a források és motivációk eloszlásának egyenlőtlensége elkerülhetetlenül hierarchikus, vertikális kapcsolatot (4. szempont) teremt a vezetők és a követők között, mégis az állampolgári preferenciák és az intézmények beszűkítik a vezető lehetőségeit és így a követők megőrizhetik kezdeményező készségüket.

A vezetők kompetensebbek, több forrással és nagyobb motivációval is rendelkeznek. Mindebből az következik, hogy ő lesz a legbefolyásosabb politikai szereplő, az ő tevékenysége számít a legmeghatározóbbnak a politikára, a döntésekre nézve (Dahl 1961, pp. 6-7; Downs 1957, p. 87; McFarland 1969, p. 154). A befolyás dahli értelmezésben annyit tesz, hogy a vezető kizárólagos stratégiai lehetősége többékevésbé „független” cselekvést kezdeményezni (Dahl és Lindblom 1953, p. 230; ld. erről: Keohane 2015, pp. 231-33). Ez abban mérhető, hogy a vezető mennyiben képes hatalmát, erőforrásait és eszközeit arra használni, hogy politikáját (szelektív ösztönzőkkel, kemény hatalmi eszközökkel vagy akár heresztetikával) keresztülvigye 
bármiféle ellenállással vagy akadállyal szemben. Ilyen értelemben a vezető pozíciójánál fogva a hatalmát mások felett (power over) gyakorolja (3. szempont). Dahl formulájával ez a hatalmi kapcsolat a következőképpen néz ki: „'A' hatalmat gyakorol 'B' felett oly mértékben, amennyiben képes 'B'-t rávenni olyan dolog megtételére, amelyet máskülönben nem tenne meg." (Dahl 1957, pp. 202-3) Ebből az következik - ahogy azt kiemeli több Dahlra építkező szerző is (Blondel 1987, p. 3; McFarland 1969, p. 154) -, hogy a vezető tevékenysége nélkül bizonyos események nem, vagy legalábbis másképp történnének meg. A vezetők tevékenysége ennek a befolyásnak és hatalomnak a megszerzésére, megtartására és tágítására irányul.

A követés kötelezettsége ugyanakkor nem lehet „általános” és „totális”, azaz nem terjedhet ki az egész politikai közösségre és nem is vonatkozhat irracionális elvárásokra (például az önfeláldozásra). Egyfelől az általános követés igénye a vezető szemszögéből irracionális is lenne. A követők - mint a vezetés címzettjei - kizárólag azon polgárok köre, akik megbízzák a vezetőt érdekeik képviseletével, másképpen fogalmazva: azok, akik támogatásukért cserébe elvárnak tőle valamit. A vezetőnek nem áll érdekében a többség megszerzésén túl kötelezettséget vállalni, vagy épp költséges részvételt generálni. Mindazonáltal a vezető nem is különítheti el élesen követőit a „többi” választótól, ugyanis a politikai folyamatnak a kompromisszum kialakításának irányába kell haladnia. Másfelől noha az engedelmesség (a kollektív cselekvés vagy a törvények betartása) „kikényszeríthető” bizonyos kemény hatalmi eszközökkel és szelektív ösztönzőkkel, az önkéntes cserekapcsolaton alapuló követés mégsem lehet „totális” önfeladás. Ugyanis ennek igénye nem csak a követői racionalitással, de még a vezetést keretező „modális” értékekkel is ütközne, amelyek a vezetőt a procedúrák, az intézmények és a plurális érdekek és preferenciák tiszteletére kötelezik.

A vezető mozgástere korlátozott, amelyet az eleve adott preferenciák, a versengő érdekek, az egyáltalán nem, vagy csak nehezen megváltoztatható intézmények, valamint a többi politikai szereplővel folytatott verseny egyszerre szabják meg. A vezető ki van tehát szolgáltatva a politikai környezetének, amellyel végérvényesen reaktív szerepbe kényszerül (5. szempont) (eventful man: Hook 1955). Leegyszerüsítve: a vezető csak követi a preferenciák és a környezet változását, mert azokra csak közvetve, korlátozottan tud hatást gyakorolni. Ez azt jelenti, hogy az elmélet nem is vár el a vezetőtől széles változásokat, átalakításokat. Sőt gyakorlati és morális okoknál fogva fontosabbnak tünik a meglévő viszonyok megőrzése, az adott közpolitikai feladat pragmatikus elvégzése. Következésképpen a vezető itt erősen feladat-orientált. 
Mindez azt is jelenti, hogy a vezető szerepét elméletileg bárki betöltheti. Ugyanis a vezetés elsősorban pozícióhoz kötött tevékenység és a vezetéshez szükséges kompetenciákat, technikai tudást természeténél fogva bárki megszerezheti. Sidney Hook (1955, p. 109) klasszikus metaforája szerint egy holland kisfiú képes megmenteni városát az ártól, ha az ujjával betömi a gát repedését. Ennélfogva a vezetés, mint cselekvés nem, de a vezető személye maga jelentéktelen, hisz bárki alkalmas lehet a feladat ellátására, aki képes használni a pozícióhoz kapcsolódó erőforrásokat és hatalmi eszközöket.

Összességében a követők rögzített preferenciájuk és az intézményes érdekérvényesítő csatornák révén képesek saját autonómiájukat és proaktív kezdeményezőképességüket megörizni (5. szempont). Így bár az elmélet értelmezésében a vezetőknek van a legnagyobb befolyása, mégis a választók kontroll alatt tartják a vezetőket azzal, hogy a döntéseket hozzájuk delegálják, amit később a következő választások során adott esetben vissza is vonhatnak, kikényszerítve ezzel a reszponzivitást és a Friedrichtörvény teljesülését. A kettőséget Dahl különösen pontosan fogja meg:

„Az biztos, hogy egy pluralista rendszerben, ahol az egyenlőtlenségek szétoszlanak, a vezetők közvetlen befolyása a közpolitikára szélesebb, mint azt a politikai filozófusok által fejlesztett klasszikus modellekben foglalt normák megkívánnák. Azonban, ha a vezetök vezetnek, akkor őket is vezetik. Ennélfogva, a befolyás - a vezetők, az alvezetők és a választók kapcsolata - ebben az elosztásában olyan makacs és átfogó kétértelműséget teremt, amely áthatja az egész politikai rendszert.” (ford., kiemelés tőlem) (Dahl 1961, pp. 101-2)

A vezetők és követők kapcsolata tehát reciprok, amelynél fogva - ahogy Burns is aláhúzza - „a vezető nehezen lesz megkülönböztethető a követőktől.” (Burns 1978, p. 258), de mégsem kerülnek egyazon szintre, ahogy azt a deliberatív-részvételi demokrácia transzformatív vezetése feltételezi. 


\section{3. Összegzés}

A képviseleti demokrácia modern megfogalmazói a politika egy materiális képét festették meg. A fókuszba az az igény került, hogy az állampolgároknak kontrollálniuk kell mind a kormányzás tartalmát, mind a kormányzat működését. Mivel az elmélet az érdekalapú konfliktusok és az állampolgári preferenciák meghatározó szerepét hangsúlyozza, ezért a demokratikus politika kérdése az, hogy miként lesz a preferenciákból kormányprogram, közpolitika, illetőleg miként lesz az érdekekből hatalmi tényező. Amíg a preferenciák eloszlása a kormányzás tartalmát határozza meg, addig a hatalom eloszlása a kormányzat müködését.

A politikai folyamatot az eleve adott (ex-ante) preferenciák kinyilvánításával a kellö mértékü és kiterjedésű, közvetett, formális (konvencionális) állampolgári részvétel indítja be. Bár a részvétel katalizátorként hat, mégis több szempontból korlátozott. Egyfelől a részvétel az állampolgárok számára irracionális lehet a magas költségek és a megtérülés kétségessége miatt. Másfelől a politikusok számára a magas részvétel válságtünetként jelenhet meg, sőt a demokratikus intézményeket tekintve akár kontraproduktív és erodáló hatása is lehet. Az állampolgárok (és a politikusok) önérdekorientáltak, racionálisak, kompetensek, de csak korlátozottan informáltak, hiszen a tájékozódás, magas költségei okán nem feltétlenül ésszerü. Az alulról-felfele (bottomup) épülő politikai folyamatot a reszponzivitás határozza meg. A politikusok a preferenciákat mechanikusan összegzik (aggregálják), az érdekeket harmonizálják, s majd képviselik azokat. Ennek értelmében a kormányon levő és újraválasztásukra törekvő pártok, politikusok igyekeznek a jövőbeli állampolgári ítéletek szerint alakítani a politikájukat, hogy azzal növeljék az újraválasztásuk esélyeit. $\mathrm{S}$ bár a pártok hatalomért, és az újraválasztásért folyó küzdelmének csak melléktermékét jelenti a közérdek, mégis a szereplők úgy alakítják programjukat, hogy az megfeleljen a többség akaratának. A politikusok viselkedését ez a kettősség határozza meg. A folyamat egy kompromisszumot megtestesítő döntésben csúcsosodik ki, amelyet végül a szavazás szentesít.

$\mathrm{Az}$ aggregatív-pluralista demokrácia központi problémája, miszerint miként lehet a kormányzó vezetők hatalmát kontroll alatt tartani, és biztosítani reszponzivitásukat a követők preferenciáit illetően, közvetlenül kötődik a vezetéshez. Az elmélet egy természetes egyenlőtlenségi állapotot feltételez. A vezető rendelkezik a legnagyobb befolyással, amelyet azonban az intézményekhez kapcsolt (modális) értékek, a hatalmi gócpontok, a politikai verseny, a konvencionális részvételi formák és a politikába 
bevont, eleve adott preferenciák egyaránt korlátoznak. A vezetők és követők közötti kapcsolat hierarchikus, vertikális, de a két fél kölcsönösen függ egymástól. Ez egy személytelen ,érdekbarátság”, amelyben bár a vezető mások felett gyakorolja a hatalmát (power over), a követők mégsem veszítik el kezdeményező képességüket, amellyel a vezetést kontroll alatt tarthatják. Kapcsolatuk piaci csereként írható le, amely csupán a kölcsönös bizalmon és a szereplök érdekein alapul. A tranzaktív vezetés, mint az aggregatív-pluralista demokrácia gyakorlata, a „politikacsinálás” kihívására - a szükséges politikai részvétel (kollektív cselekvés) biztosítására és a közérdeket megtestesítő politika kialakítására - adott válaszával járul hozzá a demokratikus politika folyamatához. A vezetés eszköztárát elsősorban olyan „kemény” hatalmi eszközök és ösztönzők alkotják, amelyekkel a vezető a politikai folyamatot, a preferenciákat csak közvetve képes alakítani és így elérni céljait. A vezető túl a pragmatista és feladatorientált beállítottságán egyszerü „mesteremberként” vagy „gépészként” csak megformázza („legyártja”) a rajta kívül álló közérdeket, illetve felügyeli és finomhangolja a politikát. Ennélfogva a politika elsősorban produktív technikai tudást (techné) igényel, amelyet bárki megszerezhet. Sőt, mivel a vezetés személytelen ugyanis kizárólag a pozícióhoz kötődik -, így az formálisan nyitva áll mindenki előtt. 


\section{5. VEZETÉS A VEZÉRDEMOKRÁCIÁBAN}

A vezérdemokrácia - nomen est omen - a vezetés gondolatára és igényére, pontosabban annak egy igen karakteres és markáns formájára épül. Az elmélet a vezetés hatékonyságával és hatásával kapcsolatos magasabb elvárásai miatt kevesebb igazi vezetőt ismer el. Ezért talán a vezért és tevékenységét egy olyan fiktív példával lehet legjobban illusztrálni, amely ugyan egy kudarcot jelenít meg, mégis találóan bemutatja a vezetés e koncepcióját. Orson Welles 1941-es klasszikus mesterműve az „Aranypolgár” (Citizen Kane) az általa játszott föhős, Charles Foster Kane média- és iparmágnás vezetése köré épül (Cronin és Genovese 2012, pp. 232-34). ${ }^{42}$ Kane az általa megöröklött vagyont médiabirodalmának építésére fordította. Az emberek elismerését, a karizmájának felismerését és személyes boldogságát keresi, amelyet a közéletben és a politikában talál meg. Médiabirodalmát saját szócsöveként használja: politikusokat támad és támogat (például Theodore Roosevelt és Adolf Hitler mellett is feltünik egyegy képkockán), valamint politikai ügyek mentén száll harcba (háborúkat „indít el” vagy botrányokat kreál). Mindezzel maga is politikai szereplővé válik. A New York Daily Inquirer kiadójaként és szerkesztőjeként elvi nyilatkozatot ad közre, amelyben ígéretet tesz azt illetően, hogy a lap gyorsan, egyszerüen és szórakoztató módon, mindenféle speciális érdek befolyása nélkül csak az igazságot jeleníti meg, és fáradhatatlanul kiáll az emberek állampolgári és emberi jogaiért.

Később függetlenként maga Kane is elindul New York állam kormányzói székéért. Egyszerű emberként lép fel, aki demagóg, populista eszközökkel száll be a választási küzdelembe. Le kívánja váltani a korrupt politikai elitet, és meg kívánja védeni azokat a hátrányos helyzetü embereket, akiket - értelmezése szerint - senki sem képvisel. Egyesek szerint kommunista, míg mások szerint fasiszta volt. Ö viszont egyszerüen a közösségét kívánta megtestesíteni: „Egyvalami voltam, vagyok és leszek: amerikai.” A választást végül egy magánéleti botránya miatt elvesztette. Kane számára a töréspontot ez a politikai kudarc jelentette, amely egzisztenciális válságba sodorta és drámai hanyatlásba taszította. „A politikában mindig koszorúslány volt és nem pedig mennyasszony" - hangzik politikai pályafutása összegzése. Akármennyire eröteljesen

${ }^{42}$ Érdemes felhívni a figyelmet arra, hogy a film Donald Trump kedvence, amelyből komoly inspirációt is merített elnöki kampánya során (Felten 2016; Hufbauer 2016). 
formálta a közvéleményt, sohasem választották meg semmilyen pozícióba. Nagy ember kívánt lenni, aki nyomot hagy a történelemben, ezt mégsem tudta elérni. Kiállásával vezetői képességeiről tett tanúbizonyságot. S bár sokan gyülölték, mégis követőket toborzott, karizmatikus közösséget épített maga köré. Egyszerre rombolta a meglévő rendet és igyekezett építeni egy újat, a sajátját. A megfogalmazott elvi nyilatkozatában „ügybuzgalmáról” és „felelősségvállalásáról” vallott. Azonban hiányzott belőle a kellő politikai gyakorlati tudás (a virtú és az „arányérzék”), amely segítette volna számára a politikai helyzetet értelmezni, valamint helyesen dönteni és cselekedni. Sikertelenségének kulcsa ebben rejlett. Ennek hiányában nem sikerült karizmáját megalapozni. Politikai kudarcának következményeként saját „birodalmában” felelötlen, hiú, megkeseredett, kiüresedett és nem utolsó sorban boldogtalan zsarnokká vált, aki fegyelmezéssel kívánta fenntartani - sikertelenül - vezérszerepét.

Összességében a film korát megelőzve mutat rá a politika perszonalizációjára, bulvárosodására és a populizmus előretörésére, amelyekben jól megjelenítette a vezér demokratikus vezetését. Felmerül a kérdés, hogy mindez mit árul el a demokrácia ezen ideájáról, illetőleg mitől lesz sikeres egy vezér, azaz mit jelent itt pontosan a jó vezetés, illetve a vezetök és a követők helyes kapcsolata? Választ kínálva az itt fellebbentett kérdésekre az alábbi fejezetben bemutatom a vezérdemokrácia politikára vonatkozó alappremisszáit és (implicit) vezetéselméletét kiemelve, hogy a vezetés miként járul hozzá a demokráciához, pontosabban miként válik lényegében azonossá a vezetés a demokratikus politika ezen felfogásával.

\subsection{A vezérdemokrácia alappremisszái}

A vezérdemokrácia (Führerdemokratie: Weber 1987) nézőpontja gyökeresen eltér az eddig tárgyalt demokráciaelméletektől. Szembefordul a demokrácia morális (deliberatív-részvételi demokrácia) és materiális (aggregatív-pluralista demokrácia) értelmezéseivel. A modern vezérdemokrácia elmélete Max Weber, Joseph A. Schumpeter és más klasszikus elitista szerzők (Mosca, Pareto és Michels) újrafelfedezésén (Körösényi 2005, 2016; Pakulski és Higley 2008; Pakulski és Körösényi 2012) és a realista (hatalom-centrikus) politikaelmélet demokráciaértelmezésén (Lord 2003; Philp 2007; Schabert 2013) alapul. Azzal, hogy az elmélet a politikát formáló „vezér” köré épül, a demokrácia egy politikai értelmezése írható le. A politika itt egybeesik a vezetéssel (politics as leadership: Tucker 1995), pontosabban annak egy karakteres olvasatával: a hatalom megszerzésével, megtartásával és használatával (az uralommal, a kormányzással). 
A demokrácia ebben a keretben egy módszer, egy eszköz a kormányzásra alkalmas vezetők kiválasztására. Weber $(1987,1989,2009)$ a vezérdemokráciát a legális és a karizmatikus uralom ötvözeteként írja le. A karizmatikus uralom rutinszerüvé, mindennapivá válik, azaz: az állam hatalmi és erőszak monopóliumát birtokló vezér pozíciójának betöltése rendszeres választások keretében történik. A választások, mint a vezetők hatalomigényének az elismerése jelentik a vezérdemokrácia formális keretét. A vezetők választási küzdelme a formális vezérségért, az államvezetésért, a kormányzásért, azaz a legitim hatalom gyakorlásáért és az erőszak használatáért folyik. Az állampolgárok szabadon választják meg, és vetik magukat alá annak a vezetőnek, akit a legalkalmasabbnak találnak. Ennélfogva a vezérdemokrácia meg is őrzi a vezetők személyének és karizmájának jelentőségét. Hasonlóképp instrumentálisan közelíti meg Schumpeter is a demokráciát. Értelmezése szerint a „demokratikus módszer olyan - a politikai döntések elérésére kialakított - intézményi elrendezés, amelyben egyesek a nép szavazataiért folytatott versengö küzdelemben szerzik meg a hatalmat a döntések felett"' (2006, p. 269). Azaz: szabad verseny a szabadon leadott szavazatokért (Schumpeter 2006, p. 271). Ilyen értelemben a „demokrácia nem jelenti, és nem is jelentheti azt, hogy a nép ténylegesen uralkodna (...). A demokrácia csupán annyit jelent, hogy a népnek lehetősége van elfogadni vagy elutasítani azokat az embereket, akiknek kormányozniuk kell őket. (...) [A] demokrácia a politikusok uralma” teszi hozzá Schumpeter (2006, pp. 284-85). Mindezek fényében a demokrácia természete két dologban áll: a vezetők a hatalomért folytatott versenyéből, illetve az azon alapuló hatalom használatából, azaz a kormányzásból.

Érezhetően lejjebb kerülnek a normatív elvárások ebben az elméleti keretben. Mindazonáltal a normatív alap mégsem tünik el. A minimalista demokráciadefiníció normatív tartalmát az adja, hogy a kompetitív és nyílt választás lehetőséget biztosít a rossz vezetők békés leváltására, húzza alá Schumpeterre alapozva Adam Przeworski (1999). Ez két dolgot is jelent. Egyfelől azt, hogy a demokrácia játékszabályai „békés harcot” eredményeznek (M. Weber 1987, pp. 64-66), másfelöl a választások kikényszeríthetik a weberi felelősségetikát (M. Weber 1989, pp. 74-75). Azaz: a vezetők felelősségvállalásra kényszerülnek, vagy megfordítva: a választók a vezetőket felelősségre vonhatják. Amíg a választás intézményéből a verseny legalitása adódik, addig a vezetők személyének a felértékelődéséből a személyes felhatalmazás és felelösségvállalás is következik. 
Az elmélet a ténylegesen létező, valóságban müködő demokrácia tapasztalatából indul ki. Az empirikus-induktív jellegü érvelés azokra a modern demokráciában tapasztalt vezetés- vagy vezér-centrikus trendekre kívánnak rámutatni, amelyek megértésére a vezérdemokrácia elméleti keretét hívja segítségül. Az elmúlt 20-30 évben empirikusan tapasztalt változások - mint a mediatizáció, a perszonalizáció, a prezidencializáció, a diszkrecionális politika erősödése, a pártok és parlamentek „válsága” (szerepének, súlyának átformálódása) - abba az irányba mutatnak, hogy egy-egy ország irányítása személyek egy jól meghatározható körére szükül le (Green 2010, pp. 122-37; Körösényi 2005, pp. 11-15; Pakulski 2013; Pakulski és Körösényi 2012, pp. 51-79). Emellett az érvelés negatív oldalaként kihangsúlyozásra kerülnek azok az empirikus tapasztalatok, amelyek rámutatnak az eddig tárgyalt két demokráciaelmélet tarthatatlanságára (Achen és Bartels 2016; Femia 2009). Az elmélet realista-empirikus megközelítésében lényegében „repolitizálni” kívánja a demokráciát, a demokratikus kormányzást, s így megkérdőjelezi vagy elutasítja - morális vagy materiális alapon - a normatív demokráciaelméletek alappremisszáit.

A vezérdemokrácia esetében még az előző két elmélethez mérten sem lehet egységes, kidolgozott elméleti keretről beszélni. Így mind a demokráciát, mind a vezetést illető alappremisszák felfejtésében nehézségekbe ütközhet a vizsgálódás. Egyrészt sem Weber, sem Schumpeter nem alakított ki egységes demokrácia- és vezetéselméleti keretet. S bár mindkét szerző csak érintőlegesen foglalkozott a demokrácia és vezetés problematikájával, mégis fontos látni azokat a feltevéseiket, amelyek teret engednek a demokratikusan választott vezér koncepciójának.

Másrészt talán az elméleti kidolgozatlanságból fakadóan nincs egységes elméleti áramlat sem. Komolyabb eltérések származnak abból, hogy a két említett szerzőt eltérően értelmezik, és így egyesek pesszimistább, míg mások optimistább következtetésre jutnak. ${ }^{43}$ Ezt illetően különösen megnehezíti a helyzetet az a tény is, hogy mindkét szerző nagy hatást gyakorolt az aggregatív-pluralista (ld. például: Downs 1957, p. 29) megközelítés szerzőire (ld. erről: Körösényi 2012). Mindazonáltal a tárgyalt szerzők között alappremisszák tekintetében párhuzam vonható, amelyek mentén egy egységes demokráciakép alakítható ki.

\footnotetext{
43 A teljesség kedvéért érdemes megjegyezni, hogy Weber plebiszciter vezérdemokráciájának van „pesszimistább” (Körösényi 2017) és „optimistább” (Green 2010) olvasata, ahogy Schumpeter demokráciaelméletének is van „pesszimistább” (Körösényi 2016) és „optimistább” (Brooker 2010) értelmezése.
} 
Harmadrészt problémásnak tünhet az elmélet empirikus irányultsága is annak fényében, hogy amíg a weberi és schumpeteri vezérdemokrácia elméletét elsősorban a bürokratizálódás (a modern államok megjelenése) és a demokratizálódás (választójog kiterjesztése, tömegpártok és választások gyakoriságának növekedése) élménye hívta életre, addig a modern vezérdemokráciát más jellegü tendenciák - úgymint a mediatizáció, a perszonalizáció és a prezidencializáció - következményeként írják le. Pontosabban fogalmazva: amíg Weber és Schumpeter a pártdemokrácia kialakulásának lehettek a tanúi, amelyben kialakulnak és hatalomra törnek a modern tömegpártok, addig a modern értelmezésben már a pártok visszaszorulásával a vezetők felerősödő szerepe jellemző. A feszültség itt abban áll, hogy a vezér megjelenése és jelentősége a demokráciában kontextuális, azaz tendenciák következménye, vagy szubsztantív, azaz a demokrácia természetéből fakad, ahogy azt - értelmezésem szerint - Weber és Schumpeter is feltételezte. Ilyen felfogásban a vezér mindig ott lehet a politikában függetlenül a szélesebb tendenciáktól. Tehát a vezér megjelenése, lehetőségei nem a kontextusnak, hanem elsősorban teljesitményének köszönhető. Az elkövetkezőkben e szubsztantív felfogásban mutatom be az elméletet.

Végezetül látni kell azt is, hogy az eddigiektől eltérően, itt az elmélet központi eleme a vezetés, amelynél fogva nehezebb elválasztani a demokráciát és az implicit vezetéselméletet érintő feltevéseket. A demokráciát illetően engem itt elsősorban az érdekel, hogy a vezetés miként határozza meg a demokratikus folyamatokat, míg majd a következő alfejezetben elemzem a vezetés belső dinamikáját. Mindezek fényében kellő körültekintéssel tekintem át a következő három pontban a vezérdemokrácia alappremisszáit.

Bemeneti oldal. A vezér akarata, döntései és cselekvése számítanak a politikai folyamat katalizátorának. Kezdeményező, proaktív félként nagyobb autonómiát élvez, amely határozott politikai akaratán és kockázatvállalási hajlandóságán nyugszik. Politikai tudással kizárólag a hivatásos politikusok rendelkeznek (Schumpeter 2006, pp. 281-82; 285; M. Weber 1989). A politikusoknak az állampolgárokétól eltérő, saját, önálló érdekeik és motivációik vannak pusztán abból kifolyólag, hogy hivatásként választották a politikát (Schumpeter 2006, p. 285; M. Weber 1989). Weber (1989, p. 7) értelmezésében „,[a]ki politizál, az hatalomra törekszik: hatalomra vagy más (ideális vagy önző) célok érdekében, vagy pedig »önmagáért«: tehát a belőle fakadó presztízs élvezetéért." Azonban nem minden hivatásos politikus számít vezérnek. Egyes hivatásos politikusok anyagi érdekeik kielégítése céljából a politikából élnek, míg 
mások - egy bizonyos ügyet szolgálva - magáért a politikáért élnek. Ez utóbbi csoporthoz tartozók számára személyes, egzisztenciális kitettségük miatt, a hatalom létfontosságú, és nem egyszerü eszköz, hogy a politikából megéljenek. E miatt cselekvésük egyszerre cél- és értékracionális (Weber 1987, pp. 53-54; ld. erről bővebben a 5.2.1. fejezetet). Ök azok, akik a politikát választott hivatásukként „müvelik”. Politikai „lángelmékként” olyan rendkívüli tehetségü személyek, akik kiemelkedő tudással, kellő információval és alkotóképességgel rendelkeznek a politika területén. A vezetés ebben az értelemben a politikai részvétel egy megkülönböztetett formája, amely csak kevesek kiváltsága lehet.

A vezérdemokrácia elmélete jelentősen pesszimistább az állampolgárok politikai szempontból releváns képességeivel, preferenciáinak súlyával és részvételével kapcsolatban, mint amennyire a korábban tárgyalt normatív elméletek voltak. A vezér és az állampolgárok között a politikai tudás és kapacitás aszimmetrikusan oszlik meg. S bár egyaránt önérdek-orientáltak, amíg az előbbi jobbára tisztában van saját érdekével, addig a követők az életüket közvetlenül befolyásoló ügyeken ${ }^{44}$ túl irracionálisak, érzelmek által vezéreltek és inkompetensek ahhoz, hogy tudatosult politikai érdekekkel és valós akarattal álljanak elő. Schumpeter (2006, p. 262) rámutat arra, hogy „,a tipikus állampolgár a szellemi teljesítmény egy alacsonyabb szintjére csúszik, amint a politika mezejére lép. Oly módon érvel és elemez, amit valódi érdekeinek szféráján belül készséggel infantilisnak ismerne el. Újra primitívvé változik. Gondolkodása asszociatív és affektív lesz.” Schumpeter (2006, pp. 258-62) követi a politika hivatás- és nem hivatásszerü üzésének a megkülönböztetését infantilizmus tézisével (Körösényi 2016); pontosabban azzal, hogy elválasztja az emberi viselkedés szükebb (a mindennapi életbéli) és tágabb (a politikai életbéli) szféráját. Az átlagember a mindennapi életben szakmájában, hivatásában és magánéletében - ismerősen, kellő realitásérzékkel, felelősségérzettel és valódi akarattal „mozoghat”. A politikát azonban csak közvetve a médián keresztül ismerheti. Így nincs a kellő információ birtokában a különböző döntésekről, opciókról és következményekről ahhoz, hogy felelősségteljesen, tudatosan és kompetensen képes legyen a politikai cselekvésre. A politikus számára viszont ez az a szüken vett szféra, ahol hivatásánál fogva magabiztosan és otthonosan képes mozogni.

\footnotetext{
${ }^{44}$ Schumpeter (2006, pp. 260-62) tisztázza a politika három különböző szféráját arra vonatkozóan, hogy az állampolgárok milyen mértékben vonhatók be a politikába. Az első területet azok a helyi ügyek jelentik, amelyeket az állampolgárok még képesek kiismerni. A másodikat azon országos ügyek alkotják, amelyek közvetlenül érintik őket, és emiatt határozott politikai válaszreakciókat váltanak ki belőlük. Az ügyek harmadik csoportját azon országos és nemzetközi ügyek alkotják, amelyekben közvetlenül nem érintettek és így legkevésbé képesek azokat átlátni.
} 
Túl azon, hogy bárki előtt nyitva áll, hogy induljon a választásokon csakúgy, mint ahogy bárki szabadon nyithat textil üzemet (Schumpeter 2006, p. 272, 6. lábj.), az állampolgárok kizárólag ,alkalmi politikusokká” (M. Weber 1989, p. 15) válhatnak: a szavazócéduláikat az urnába dobhatják, az utcára vonulhatnak, tapsolhatnak, vagy akár tiltakozhatnak. Tevékenységük azonban - hol aktív, hol meg passzív módon - de ténylegesen arra szorítkozik, hogy elfogadják vagy elutasítják a vezetőket és döntéseiket. Ezzel az állampolgárok alárendelődnek a politikusok, a vezetők akaratának. $\mathrm{Az}$ állampolgári részvétel a vezetők szelekciójára, politikájuk szentesítésére korlátozódik, amelyet plebiszciter stratégiával és mozgósítással generálnak. A vezérdemokrácia plebiszciter jellege okán, azaz a vezetők megválasztásának körülményei között, nem a politikai értelemben passzív tömeg az, amely életet ad egy vezetésnek, hanem a vezető demagóg eszközökkel mozgósítja és aktivizálja a tömeget, és végeredményben értelmet ad politikájának.

Ezen a ponton azonban kritikussá válik az állampolgári részvétel. Bár tartalmát és jelentőségét tekintve beszükül, de a vezérdemokrácia is igényli az állampolgári részvételt, a vezér aktív és/vagy passzív elfogadását. A politikában rejlő bizonytalanság miatt a vezetők nem képesek a szituációkat teljesen kezükben tartani, nem képesek közvetlenül megszabni, hogy mit gondolnak róluk az állampolgárok. Az állampolgárok - Jeffrey Green (2010) értelmezésében legalábbis - a politika megfigyelőiként képesek kontroll alatt tartani, vagy legalábbis korlátok közé szorítani a vezető nyilvános megjelenését, a politikai helyzet megítélését. $\mathrm{S}$ noha ebből nem következik egyértelmüen az, hogy a politikusok, a vezetők „őszinték” (candor) lesznek (vö. Green 2010), mégis feltételezhető, hogy a vezetők mindent megtesznek azért, hogy oly módon jelenjenek meg a különböző helyzetekben, amilyeneknek az állampolgárok többsége látni akarja őket. A vezérdemokráciában ez a külső- és részben belső megfelelési kényszer ad értelmet az állampolgárok részvételének és bevonásának. Ilyen értelemben az állampolgári részvétel kényszeríti a vezetőket arra, hogy igazolják cselekvésüket, tevékenységüket. Mindebből az következik, hogy általánosságban az állampolgárok passzív jelenlétére, azaz a politika megfigyelésére van szükség, míg az aktív részvétel, az alkalmi politika csak akkor válik kívánatossá, ha alkalomszerüen támogatni vagy leváltani kell egy vezért.

A politika folyamata. Eltérően az eddig tárgyalt két demokráciaelmélettől, itt a politikai folyamat felülről lefelé (top-down) épül. A politikai folyamat tartalmát, irányát, dinamikáját és belső kohézióját a vezetők hatalomért folytatott versenye, állandó 
választási küzdelme határozza meg, amely a kormányon levők felől nézve a hatalom megtartását jelenti. A politikai folyamatot illetően két jellegzetességre kell figyelmet fordítani.

Egyrészt a politikai folyamatot monopolista verseny jellemzi (Körösényi 2012). Ez nem hasonlít az aggregatív-pluralista demokráciaelmélet által feltételezett „,ökéletes” piaci körülményekhez, amelyben az egyensúlyi állapotot, a közjó alapját, a mediánszavazó politikai preferenciái jelentik. A vezérdemokrácia számára a politikai verseny természetes monopóliumok müködtetéséért folytatott „békés” küzdelemként (Weber), versengésként (Shumpeter), vagy kicsit pontosabban ,árverési piacként” kerül megfogalmazásra (Tullock 1965). Az inkumbencia, a kormányzás olyan természetes monopólium, amelynek kizárólagos, de időben megszabott birtoklásáért, felügyeletéért folyik a politikai verseny (competition for the field: Wohlgemuth 2000). A legitim kormányzó hatalomgyakorlása a vetélytársak időleges kizárását vonja maga után. A választók, mint politikai fogyasztók szemszögéből a politikai verseny csak periodikusan, a választások alkalmával nyílik meg. A versenybe való belépésnek igen magas politikai és intézményi küszöbei és költségei lehetnek. Más versenykorlátokkal együtt ezek leszükítik a versenyt és így kiélezhetik a vezetők önszelekcióját és egyszersmind felértékelik a vezetők személyes képességeinek jelentőségét. A konkuráló vezetők külső, piaci és belső, hivatásból fakadó okoknál fogva rákényszerülnek a politikai terméket érintő innovációra.

Másrészt a politikai folyamat lényege a közérdek, mint termék kreálásában és annak „eladásában” rejlik. Az elmélet értelmezésében nem létezik eleve adott vagy valamilyen kollektív módon kialakított, racionális alapokon nyugvó közérdek, népakarat. Max Weber úgy fogalmaz protezsáltjának, Robert Michelsnek írt levelében, hogy ,[o]lyan koncepciónak, mint »a nép akarata«, »a nép igazi akarata« és így tovább, számomra réges-rég megszünt a valóságtartalma. Ezek nem többek, mint fikciók.” (ford. tőlem) (idézi: Mommsen 1990, p. 395) Az eddigi két demokráciaelmélethez képest, itt tehát nem létezhet olyan közérdek, amellyel minden ember racionális indokok mentén egyetérthetne (Schumpeter 2006, pp. 251-52). A népakarat csak előállított (manufactured) politikai termékként kap fontos szerepet. Schumpeter (2006, p. 263) szavaival: „a népakarat a politikai folyamat terméke és nem mozgatórugója”. A közérdek levezethetővé válik a politikusok, a vezetők akaratából, melyet úgy állítanak elö, mint „ahogyan a kereskedelmi reklám müködik” (Schumpeter 2006, p. 263). Schumpeter infantilizmus tételéből (Körösényi 2016) következően az állampolgárok 
nem, vagy csak korlátozottan rendelkezhetnek eleve adott preferenciákkal, sőt cselekvésüket tekintve irracionálisak és affektívek. Az érzelmek és előítéletek előtérbe helyezik a politikai befolyásolás és manipuláció eszközeinek a használatát. A hatalom megszerzésének a kulcsa a preferenciák manipulálásában, a közérdek, a közjó és a népakarat kialakításában rejlik. A vezetök akár populista, demagóg eszközökkel is, de igyekeznek új alternatívákat kínálni a népakaratra, a közjóra; és követőket toborozni, választókat mobilizálni. A vezetőknek a „választási csatatér diktátorává” (M. Weber 1989, p. 50) kell válniuk, amellyel a vezérdemokrácia egy „cezarisztikus” elemet emel be a politikába. S ilyen formában a demokrácia a „tömegek érzelmeinek kihasználásán nyugvó” diktatúrává válik (M. Weber 1989, p. 52).

Mindennek három normatív implikációjával kell számolni. Elöször is a vezetők értelmezik és érthetővé teszik a politikai helyzetet az állampolgárok számára, azaz bevonják őket a politikába. Másodszor a vezetők versenye felszínre hozza és a kormányzás során fel is oldja a mélyebb politikai konfliktusokat. Harmadszor a közérdek „fikciójának” megvan az az integráló funkciója, hogy összekapcsolja a vezetőket, a vezért a választókkal és a választókat egymással. Leegyszerüsítve: közösséget, közösségi identitást hoz létre.

Kimeneti oldal. A politikai folyamat semmiképpen sem egyirányú. A választások alkalmával a vezetők lényegében a választók beleegyezését kérik a kormányzásra, akik ezzel elfogadják vagy visszautasítják a vezetők igényét a hatalomra. A szavazás szerepe abból a szempontból válik kritikussá, hogy az nem a pártprogramról, hanem a vezető személyéről szól. A választás - hosszú önszelekciós folyamat utolsó szakaszaként - a vezetőkbe vetett bizalom mérőeszköze lesz. A másik oldalról megközelítve: a választók fel- és elismerik a jelöltek alkalmasságát és felhatalmazzák őket a döntéshozatalra. Ez a felhatalmazás nem egyszerűen lemondás a közös ügyekben való döntés jogáról, hanem a vezetők „felkenése” a vélt vagy valós kollektív problémák megoldására.

A vezetők tehát szabad mandátumot kapnak, amellyel lényegében felhatalmazást és bizalmat szereznek arra, hogy mások; a nemzet, a nép nevében cselekedjenek. Ezzel egy sajátos viszony jön létre. A vezérnek ki kell állnia a közösségért és az általa meghatározott közérdek szerint kell cselekednie. Ebben az értelemben a politika kimenetele maga a politikai kormányzás: egy vízió megfogalmazása, elfogadtatása és megvalósítása, amely kiutat jelent a közösséget gyötrő nehézségekből. A demokratikus politikai folyamat erénye pont az, hogy képes kitermelni azt az erős, független és kreatív vezetést, amely határozott irányt és stabilitást képes adni a politikának. Ez 
különösen fontos annak fényében, hogy a politika folyamatát általánosan bizonytalanság, kiszámíthatatlanság jellemzi, amely válsághelyzetekben különösen látványos és kritikus lehet. Sőt, az iránymutatáson és az elvárt (szak)politikai innováción túl nagyobb változás, mint például egy új rezsim alapításának az igénye is felmerülhet. Mindazonáltal a változás mértékétől, irányától és tartalmától függetlenül a politikai konfliktusok - melyeket a politikai verseny elötérbe hozott és kiélezett - ha csak időlegesen is, de nyugvópontra kerülhetnek, ugyanis a választások eredményét nem kérdőjelezhetik meg a felek.

A vezérre teljesítménykényszer nehezedik. Amennyiben a megfogalmazott probléma nem kerül megoldásra, azaz a vezér alkalmassága a kormányzásra nem igazolódik be, akkor a bizalmat megvonják a választók és új vezér-jelöltet keresnek. A vezérdemokráciában - ha Webert komolyan vesszük - a felhatalmazás során nem válik tisztán szét az előzetes, jövőre irányuló döntés - azaz az alkalmasság felismerése (felhatalmazás) - és az utólagos alkalmasság beigazolódása, azaz a felelősségre vonás, a politikai teljesítmény elismerése (felhatalmazás visszavonása/megújítása, elszámoltatás) (vö. Körösényi 2006, 2007). Így a választások nem csak a vezetők felhatalmazására adnak lehetőséget, hanem optimális esetben a rossz vezetők elszámoltatására is.

\subsection{A vezérdemokrácia implicit vezetéselmélete}

A vezérdemokrácia keretében a vezetés személy- és pozícióközpontú megközelítésével részben az ún. „great man” elméletekből (Grinin 2010; ld. még: Csizmadia 2006a, p. 29; Elgie 2015, pp. 5-12), a történelmet formáló vezető ideájából (event-making: Hook 1955) táplálkozik, de mivel nagyobb hangsúlyt helyez a követőkre, a követés mozzanatára, azon túl is mutat. A vezér cselekvése két irányból ragadható meg: a karizmatikus vezető (Tucker 1968; M. Weber 1987, pp. 248-60; 271-75, 1989, 2009, pp. 340-417) $)^{45}$, és az innovatív vállalkozó (Brooker 2010; Schumpeter 2006)

\footnotetext{
45 Ezen a ponton fontos aláhúzni, hogy a burnsi transzformatív - és a weberi karizmatikus vezetést gyakran párhuzamba állítják (Antonakis 2018). Szélesebb fogalmi értelemben: amíg a karizmatikus vezetésre fokuszáló munkák (House) csak igazán kis különbségeket fedeznek fel a két koncepció között, addig a transzformatív (Burns) vagy transzformációs (Bass) vezetés fogalmára építő elemzők a karizmát csak egy fontos, de nem elégséges elemnek írják le a transzformáció folyamatában. Antonakis és kollégái (2016) átfogó tanulmányukban, melyben a karizma konceptualizációjára és operacionalizációjára vállalkoznak leválasztva róla a transzformatív vezetést, felhívják a figyelmet a két fogalom összemosásának problémájára. A probléma gyökere abban rejlik, hogy a transzformatív/transzformációs vezetést és az azzal összemosódó karizmatikus vezetést föként a folyamat eredményének és következményeinek fényében definiálják a vezetéskutatásban. Ez viszont tautológikus és homályos definícióhoz vezet, ahogy a szerzők aláhúzzák: transzformatív/karizmatikus vezető az, aki képes átalakítani (transzformálni). Visszatérve: bár a weberi és burnsi koncepció sok tekintetben hasonlít egymáshoz a változás igényében vagy a megváltó, szimbolikus „hős” ideájában, mégis három pontban fogalmilag eltérnek (vö. Boda 2013, p. 80; Kane 2001, pp. 29-30). Egyrészt, a transzformatív vezetés aktívabb szerepet szán a követőknek és morális célt tűz ki, etikai aspirációt fogalmaz meg (Burns 1978,
} 
irányából. ${ }^{46}$ A két megközelítés hangsúlyeltolódásokat rajzol fel. Amíg a karizmatikus vezető weberi koncepciója a hatalom megszerzését és megtartását a követőkkel kialakított karizmatikus kapcsolatában látja, addig az innovatív vállalkozó elképzelése a hatalom megszerzésére fókuszál, amelynek a kulcsát a minőségi változás ígéretében és véghezvitelében írja le. Mindezen eltérések ellenére a vezér két megfogalmazása összekapcsolódik egy erős, hatékony vezetés ideájában a következő pontok mentén:

- A jó vezetés kulcsát a vezér személye jelenti, aki különleges politikai képességekkel rendelkezik. A vezetés a közösség által felhatalmazott vezető kezében összpontosul, amely az alapján ítélhető meg, hogy mennyiben képes az elé kitüzött, vagy az általa megfogalmazott célokat elérni.

- A vezérnek bizonyítania kell alkalmasságát (személyes képességeit és erényeit); valamint változást, innovációt kell hirdetnie és megvalósítania.

- A vezér céljainak eléréséhez nem állnak rendelkezésre eleve adott technikák, praktikák és morális elvek. A vezetéshez gyakorlati tudásra van szükség, amely képessé teszi a vezért, hogy bármilyen körülmények között döntsön és cselekedjen.

- A vezetők és követők között „,személyes”, érzelmi kötődés alakul ki. S így a követők alávetik magukat a vezetőnek, aki a közösség identitásának forrásaként jelenik meg.

Az egyszerüség kedvéért a karizmatikus vezetés megnevezést használom a vezér cselekvésének leírására abban az értelemben, hogy az magában foglalja a vezér fogalmának mindkét interpretációját. A következő részekben a korábban meghatározott szempontok mentén a vezérdemokrácia implicit vezetéselméletét tárom fel.

2003). Másrészt, Burns (1978, pp. 45-46) nyíltan szakít a weberi etikai felfogással, a felelősség- és érzületetika dichotómiájával és az ún. végső értékek (a szabadság, az egyenlőség vagy az igazság) mentén írja le koncepcióját (Burns 1978, pp. 46; 426). Ezzel óhatatlanul értékracionális cselekvést ír le, amely kizárólag az érzületetika keretében ítélhető meg. Harmadrészt, Burns (1978, pp. 243-44) elhagyja a karizma fogalmát, melyet túlterheltnek és homályosnak ítél meg. Helyette a hősies vezetés (heroic leadership) kifejezést használja hasonló tartalommal, de a transzformatív vezetés koncepciójának alárendelve.

${ }^{46}$ Érdemes megemlíteni, hogy a vezér koncepciójával párhuzamba állítható Machiavelli újra felfedezett fejedelemével (Lord 2003; Mansfield 1989; Philp 2007; Schabert 2013) is. Mindazonáltal a vezetést itt egyértelmüen megelőzi, sőt felülírja az ,államvezetés” („statecraft”: Lord 2003; „the Executive”: Mansfield 1989; „political conduct”, „political rule”: Philp 2007), sőt egyes esetekben a szerzők maguk is megküzdenek a vezetés fogalmával, amelyet végül elvetnek (Schabert 2013, pp. 44-45). A neomachiavelliánus fejedelem számára az elsőrendü feladatot nem a formális hatalom megszerzése és igazolása, hanem annak megtartása és erényes használata jelenti, amelyhez jó (erős) kormányzásra és hatékony államvezetésre van szükség. Itt a követők szerepe elhalványul; a szélesebb követőtábor csupán másodlagos tényezővé válik, ha egyáltalán kellő figyelmet kap. Ezért ehelyütt elsősorban a weberi és schumpeteri vezetéskoncepcióra támaszkodom. 


\subsubsection{A ,jó" vezetés}

A hatalmat a vezetök nem öncélúan keresik (vö. Schabert 2013). Ilyenformán nem is tekinthető a hatalom megszerzése és megtartása önmagában értelmezhető célként. A vezér elött legfontosabb kihívásként (1. szempont) a politikát inherensen jellemző bizonytalanság leküzdése és kezelése áll. Ezzel két dolgot is állítok. Egyfelől leíró szempontként azt, hogy a politikát még normál állapotban is állandó bizonytalanság, kontingencia jellemezi, amely krízishelyzetekben még látványosabbnak és kritikusabbnak tünik. Másfelől normatív szempontként a politikai értelemben vett rend, stabilitás, rugalmasság és biztonság önértékkel bír. Ennélfogva a vezetőknek, a vezérnek hősként, „biztos pontként” kell fellépniük a politika színterére, el kell érniük a közösség elé kitűzött célokat, meg kell oldaniuk a megfogalmazott problémákat és meg kell menteniük a közösségüket. A hatalom megszerzése és megtartása tehát nem jelenthet kizárólagos célt a vezér számára, az csupán eszköz, hogy saját ambícióit, becsvágyát kiélje, személyes dicsőséget elérve, politikát és történelmet formáló nagy tetteket hajtson végre, új rendet teremtsen. A karizmatikus vezetés kihívása két mozzanatban érhető tetten.

Az első mozzanat: a vezérnek bizonyítania kell különleges személyes képességeit és erényeit, karizmáját, amelyek alkalmassá teszik a kormányzásra. A vezér személyes életét teszi fel a politikára, amelyre hivatásként tekint. Tehát nem kizárólag egy magasabb morális cél eléréséért, abszolút érték érvényesítéséért küzd (transzformatív vezetés), s nem is egyszerüen a saját személyes érdekeit elérve, a politikából kíván megélni (tranzaktív vezetés), hanem magáért a politikáért él. A vezér a hatalom birtoklásának érzésében és az általa megfogalmazott célra történő használatában találja meg az önmegvalósítás lehetőségét. Weber úgy fogalmaz, hogy ,annak, aki a »politikáért« él, ez belsőleg »jelenti az életet«: vagy az általa gyakorolt hatalom puszta birtoklását élvezi, vagy belső egyensúlya és önérzete táplálkozik abból a tudatból, hogy valamilyen »ügy« szolgálatával értelmet ad az életének.” (M. Weber 1989, p. 17) Negatív megközelítésben ez a személyes kitettség, érintettség azonban azt is jelenti, hogy a politikus képességei és közvetlen személyes felelőssége is kritikussá válik.

A történelem és a politika menetét meghatározó vezér cselekvését, Weber a szenvedélyes ügybuzgalom, felelősségérzet és arányérzék (realitásérzék, szemmérték) „erényében” fogja meg. A vezetőnek aktívan el kell köteleződnie egy ügy mellett, amely értelmet ad politikájának. Önmagában ennek megléte persze senkit sem tesz vezérré, ahhoz az ügy tekintetében felelősségérzetet kell tanúsítania, amellyel valódi 
tartalmat ad politikájának. Ezen erények hiányában, vagy ezek aránytalan megléte esetén a vezetők azonban könnyen beleeshetnek a politikai hiúság és/vagy a felelőtlenség csapdájába. A személyes jelenlét túlságos előtérbe helyezése hiúságot eredményez. Valós tartalmi szándék nélkül a demagóg vezér hatásvadásszá, színésszé válik, azaz pusztán a politikai hatást, az érzelmi benyomást helyezi politikája középpontjába. Ahol a vezető a hatalmat pusztán a hatalom kedvéért gyakorolja, kielégítve saját ambícióit, ott a hatalmi harc korlát és kritika nélkülivé válik. Mindez nem jelent ellentmondást az elmélet demokráciaképével, ahogy Weber is aláhúzza:

„[j]óllehet (...) a hatalom elkerülhetetlen eszköz és a hatalmi harc minden politika hajtóereje, a politikai erőnek nincs károsabb torzulása, mert a parvenü kérkedés a hatalommal, a hatalom érzetében való öntetszelgés és általában a hatalomnak pusztán a hatalomért való imádata.” (M. Weber 1989, p. 67)

Az ilyen politikusból, aki csupán „kultuszra” törekszik, nem csak az ügyszeretet, de az arányérzék, a távolságtartás is hiányzik, amely önmagában véve politikai bűn. Az arányérzékre, mint pszichológiai jellemvonásra a vezérnek azért van szüksége, hogy hűvösen, nyugodtan, belső lelkierővel és kellő távolságból tudja megítélni környezetét (dolgokat és embereket) és saját magát és szenvedélyét. Pontosabban: a vezérnek hagynia kell „a valóságot hatni önmagára” (M. Weber 1989, p. 66). Amíg az ügyszeretet a politikai hiúságot küszöböli ki, addig az arányérzék a felelőtlenségnek szab határt azzal, hogy kiegyensúlyozza az ügyet érintő szenvedélyt és felelősséget. Így válik a karizmatikus vezetés - Weber gondolatát (M. Weber 1989, p. 87) némiképp konkretizálva - kemény deszkák erőteljes és lassú átfúrásává, kellő szenvedéllyel és szemmértékkel.

A karizmatikus vezetéshez a fej és a lélek (M. Weber 1989, p. 85) egyaránt szükséges. Amíg a transzformatív vezetésben kizárólag az érzületetika nyomai voltak felfedezhetők, addig a tranzaktív vezetést a demokratikus procedúrákból következően túlnyomórészt a felelősségetika érvényesülése segíti elő. Itt a két megítélési sík elválaszthatatlan egymástól. Az érzületetika a vezér ügyszeretetében nyilvánul meg. Az ügy a saját közösséget meghatározó értékekhez kapcsolódik, amelyből a parancsok és tiltások következnek. A felelösségetika viszont a vezető felelősségérzetét állítja az értékelés középpontjába, amelyet a demokráciában a választások intézményén keresztül a választók kényszeríthetnek ki a támogatásuk megvonásával, a felhatalmazásuk visszavonásával. Lényegében ehhez szükséges az arányérzék: hogy a követők elvárásait 
és saját személyes és a közösséget érintő ambícióit kiegyensúlyozza. A karizmatikus vezetésnek összhangba kell hoznia a vele szemben - a szélesebb vagy szükebb közösségében - felmerülő elvárásokat azt illetően, hogy azokban idealizmusa (érzületetika) vagy realizmusa (felelősségetika) domináljon. Machiavelli (2015, pp. 9194) tanácsa itt nyer igazán értelmet: a vezérnek minden esetben uralnia kell a róla kialakuló képet, pontosabban azt, hogy adott helyen és időben épp melyik etikai mérce szerint kerüljön megítélésre.

Mindez azt is jelenti, hogy a vezért cselekvésében egyszerre határozza meg a cél- és az értékracionalitás. Weber (1987, p. 54) nyomatékosan aláhúzza, hogy tiszta értelemben vett formák ebben az esetben sem léteznek. Ahogy az már korábban említésre került, az aggregatív-pluralista demokráciában megfogalmazódó állampolgári politikai cselekvést, és a tranzaktív vezetést is elsősorban egyaránt a célracionalitás határozza meg. Ennek értelmében a racionálisan kiválasztott és mérlegelt célokhoz a vezetés a feltételeknek, várakozásoknak megfelelően válogatja meg az eszközeit, ahogyan a célok kijelölését illetően is mérlegel a kézenfekvő lehetőségek és eszközök tekintetében. Túl azon, hogy a cselekvés igazodik az eszközökhöz, a vezető racionálisan egyezteti is az eszközöket a célokkal és a várható következményeket a különböző alternatívákat is figyelembe véve. A deliberatív-részvételi politikát - a habermasi kommunikatív cselekvés keretében viszont sokkal inkább az értékracionalitás jellemzi. Az értékracionális cselekvést egy etikai értékbe vetett tudatos hit határozza meg. A vezető nincs tekintettel a következményekre, ugyanis cselekvését egy „ügy” iránt érzett kötelesség, méltóság, vagy egyéb külső (vallási, etikai) útmutatás diktálja. A célracionalitás szempontjából az értékracionalitás mindig irracionálisnak hat, annak függvényében, hogy az mennyiben rendeli alá magát egy abszolút értéknek, a „tiszta érzületnek”. A vezér ügyet érintő elhivatottsága (szenvedélye) és tartalmi víziója (felelőssége) egyszerre kívánja meg az érték- és célracionalitást, amelyek összességében a vezér cselekvésének belső logikáját jelentik, míg külső értékelését az ezzel párhuzamos érzület- és felelősségetika adja.

Fontos tudatában lenni annak, hogy a karizmatikus vezetés esetében nem állnak rendelkezésre általános morális elvek vagy technikai használati útmutatók, amelyek irányíthatnák a vezető kezét. Az eszközök és célok kiválasztásához gyakorlati tudás szükséges (praxisz: Körösényi 2005, pp. 232-33) (2. szempont). A gyakorlati tudás annyit tesz, hogy a vezér a körülményeket meghaladva, áthidalva is képes dönteni, cselekedni és végeredményében elérni a céljait. A vezér arányérzéke jelenti a gyakorlati tudás fokméröjét. Azaz, hogy politikai döntéseiben mennyire képes a vezető összekötni 
a választott értékek világát és a vizionált célokat a valósággal; valamint annak megfelelően cselekedni. Az arányérzék párhuzamba állítható Machiavelli (2015, p. 29) politikai erényével, a virtúval, amely segíti a vezért a tökéletes alkalom felismerésében és kiaknázásában. Leegyszerűsítve a vezetőt gyakorlati tudása, politikai erényei és arányérzéke vezeti a helyes döntés meghozatalában és a cselekvésben; illetőleg annak meghatározásában, hogy mely cselekvési logika és értékelési sík a legmegfelelőbb a számára.

Bár kijelenthető, hogy egy-egy politika sikeressége vagy sikertelensége a vezetők, a vezér erényein alapul, mégis ez a megállapítás semmiképp sem lehet pontos és kielégítő. Ugyanis teljességgel lehetetlen tételesen meghatározni azokat a jellemvonásokat és tulajdonságokat, amelyeken a vezető sikere alapul. Ahogy a politikai döntések, úgy az erények is erősen beágyazódnak az adott kontextusba. A vezetőnek egy adott ponton a legmegfelelőbb cselekvést és erényt kell kiválasztania (Philp 2007, pp. 41-42; 48). A weberi gondolatra alapozva nem lehet egyetlenegy egyéni, s így egyedi tulajdonságra visszavezetni a vezér sikerét: „mindig fönnáll az a veszély, hogy ellenőrizetlen értékeléseket viszünk az empirikus kutatásba, és főleg, hogy sikernek tüntetjük föl azt, ami az egyes esetben gyakran tisztán egyedi feltételeken múlik, tehát a szónak ebben az értelmében »véletlen«.” (kiemelés az eredetiben) (M. Weber 1987, p. 66). Ilyen értelemben az is Machiavelli által döntő körülményként leírt szerencse (fortuna) kérdése, hogy az adott szituációban, mely erény lesz kritikus a siker szempontjából.

A politikai tudásban rejlő esetlegesség megértésének kulcsa a weberi politikai verseny leírásában rejlik, amely darwini küzdelemként jelenik meg. A „békés” harcban ugyan nem fizikai erőszakkal, de a legitim erőszak használatáért folyik a küzdelem. Így a verseny a vezér „kiválasztódásáról” szól:

„A tipikus és tömegméretekben előforduló küzdelem és versengés minden formája hosszú távon mégiscsak azt eredményezi, hogy »kiválogatódnak« azok, akik nagyobb mértékben rendelkeznek a győzelem szempontjából általában fontos személyes tulajdonságokkal.” (M. Weber 1987, p. 65)

A versengés körülményei - a politikai szituáció, a szélesebb társadalmi kontextus és a választói elvárások - határozzák meg a sikerre vezető tulajdonságokat. A „kiválogatódás” értelemben vett harc során a vezetők - és velük együtt erényeik, tulajdonságaik is - kiszorítják egymást. 
„A nagy fizikai erő vagy a lelkiismeretlen ravaszság, az intenzív szellemi teljesítőképesség, vagy a nagy hangerő és az ügyes demagógia, a felettesekkel szembeni alázat, vagy hízelgés a tömegeknek, az eredetiség, az önálló teljesítmény vagy a nagyfokú szociális alkalmazkodóképesség, inkább rendkívüli tulajdonságok vagy inkább olyanok, amelyek nem emelkednek a tömeg átlagszínvonala fölé. (...) A »társadalmi kiválogatódás« elsősorban (...) csak azt jelenti, hogy bizonyos típusú magatartás, és így adott esetben bizonyos típusú magatartás, és így adott esetben bizonyos típusú személyes tulajdonságok is elősegíthetik egy meghatározott társadalmi kapcsolat létrejöttét (elősegíthetik, hogy valakiből »szerető«, »férj«, »képviselő«, »hivatalnok«, »építésvezető«; »vezérigazgató«, »sikeres vállalkozó« stb. váljék)” (kiemelés az eredetiben)

(M. Weber 1987, p. 65)

Emellett a weberi karizma koncepció is csak az erények homályos keretét adja. Ennélfogva a karizma konkrét tulajdonságokra való bontása is tévútra vezetné a vizsgálódást. A karizma, mint „kegyelmi ajándék”, mely fogalmát Weber (1987, p. 224) Rudolph Sohmtól vett át, lefejtve róla annak ókeresztény tartalmát, itt már nem Isten, hanem a nép, a követők adománya (M. Weber 1987, pp. 249; 272). A karizma a vezér nem mindennapi képességeire mutat rá, ${ }^{47}$ annak tartalmát minden esetben a követők adják meg. A vezetés érvényességét így a karizmába vetett hit jelenti.

„Képességet hogyan ítélnők meg etikai, esztétikai vagy bármilyen más szempontból „objektíve” helyesen: itt egyedül az a lényeg, hogy ténylegesen hogyan ítélik meg a „hívek”, a karizmatikus uralomnak alávetettek (...) A karizma akkor érvényes, ha valamiképpen - eredetileg mindig csoda folytán - beigazolódik, s ennek következtében az alávetettek szabadon - csupán a megnyilatkozás iránti odaadásból, a hős iránti odaadásból, a hős iránti tiszteletből vagy a vezér iránti bizalomból elismerik." (kiemelés az eredetiben) (M. Weber 1987, p. 248)

Ilyen értelemben a karizmatikus vezetés sikere valójában abban áll, hogy a vezér képese meggyőzni kivételességéről és rátermettségéről azokat a követőket, akik a küldetésének a címzettjei (M. Weber 2009, pp. 342-43; 345-47). A karizma belső

\footnotetext{
47 Definíció szerint: „karizmának nevezzük egy személyiség nem mindennapinak számító képességeit (...), amelyek miatt ezeket a személyeket természetfölötti vagy emberfölötti, vagy legalábbis sajátos, nem mindennapi, nem mindenki számára hozzáférhető erőkkel vagy tulajdonságokkal (megáldott) embereknek, vagy isten küldöttének, vagy példaképnek, s ezért »vezérnek« tekintették." (kiemelés az eredetiben) (M. Weber 1987, p. 248)
} 
igazolást igényel és egy jól meghatározható, a vezető által lehatárolt közösségnek szól. Ezzel a követők magukévá teszik, belülröl átélik a karizmát, alávetik magukat a tulajdonosának. A választások lényegében arról szólnak, hogy az adott személyek közül ki számít alkalmasabb karizmatikus vezérnek. Azonban az elismerés ingatag és bizonytalan (M. Weber 2009, p. 345), azaz a karizma birtokosa könnyen elveszítheti karizmatikus tekintélyét, amennyiben „vezetése nem hozza meg az alávetetteknek a jólétet és a boldogulást” (M. Weber 1987, p. 249), azaz a vezető tartósan sikertelenné válik. S ezen a ponton kezdődik a követők részéröl a várakozás és a remény, amellyel keresik a karizma új birtokosát.

A második mozzanat a vezér által megfogalmazott és véghezvitt politikai innováció és kialakított új rend, amellyel a vélt vagy valós kollektív problémákra kíván megoldást nyújtani. A szenvedélyes ügyszeretet implikálja az erős víziót és az innovatív politikát, amely önmagában nem elégséges, hiszen annak véghezvitelén, hatékony végrehajtásán van a hangsúly (Brooker 2010, p. 37; M. Weber 1987, p. 249, 2009, pp. 345-46). Az innovatív politikai alkotás - nyilvánuljon az meg közpolitikai, ideológiai vagy épp intézményes szinten is - önértékkel bír a vezető számára. Ez jelenti a személyes politikai küldetését, dicsőségének kulcsát és a karizmájának (Weber), vállalkozásának (Schumpeter), és végső soron a hatalmának (Schabert) az alapját.

A politikát állandó bizonytalanság, meghatározhatatlanság, kockázat, azaz kontingencia jellemezi; amelynek szintje a különböző válságok során hatványozottan megnőhet (Körösényi 2005; Körösényi, Illés, és Metz 2016). A bizonytalanság egyszerre jelent külsődleges kihívást és a cselekvés által - szándékolt vagy nem szándékolt módon gerjesztett „belső” hullámokat. Amíg az előbbi forgatókönyvet Kari Palonen (1998) „machiavelli pillanatnak” (Machiavellian Moment), addig az utóbbit „weberi pillanatnak" (Webersche Moment) nevezte. ${ }^{48}$ Amíg Machiavelli fejedelmének egyfajta „gátmunkásként” kell „gátakat és töltéseket” építenie a megáradt pusztító folyó (fortuna) megszelídítésére (Machiavelli 2015, pp. 127-28), addig Weber a politikai tevékenységet „kemény deszkák erőteljes és lassú átfúrásaként” (M. Weber 1989, p. 87) jellemzi. Itt azonban nem a különbözőségük tünik fontosnak, ugyanis a modern politika (választási ciklusok, intézményi környezet, politikai kihívás stb.) minden esetben összeolvasztja azokat. A vezér számára egyszerre fontos és állandósult a küzdelem a hatalom megszerzéséért, megteremtéséért (weberi pillanat) és annak fenntartásáért

\footnotetext{
${ }^{48}$ Lásd erről bővebben: (Körösényi, Illés, és Metz 2016). A „Machiavellian Moment” kifejezés eredetileg J. G. A. Pocock (1975) fogalma, míg a „Webersche Moment” elnevezés Palonen németül megjelent könyvéből származik. Ezért szerepel a két kifejezés egymástól eltérő nyelven.
} 
(machiavelli pillanat). Egyszerre kell küzdeni a bizonytalanság ellen (machiavelli pillanat) és azon keresztül cselekedni (weberi pillanat). A vezetéshez szükséges mozgástér egyszerre igényli a lehetőség passzív felismerését (machiavelli pillanat) és proaktív megteremtését (weberi pillanat). A kreatív alkotó folyamatban nem választható szét ez a két perspektíva.

A politika bizonytalansága - ehelyütt mindegy, hogy normál vagy rendkívüli állapotról van szó - hívhatja elő a karizmatikus vezetést, amely egyszersmind a vezetőt folyamatos alkotásra is készteti (Schabert 2013). „[P]szichikai, fizikai, gazdasági, etikai, vallási vagy politikai szükség,” (M. Weber 2009, p. 341), vagy „különleges esemény” (M. Weber 2009, p. 378) megteremti vagy megerősíti az állampolgárokban az új rendet ígérő karizma, karizmatikus vezetés igényét. A vezetés értelmezi a politikai helyzetet és jelentést ad az eseményeknek (Tucker 1968, 1995, pp. 17-18; 47-59). A válság érzetét ilyen módon a vezető formálja, manipulálja és kreálja (Körösényi, Illés, és Metz 2016). Összességében a bizonytalanság, a válság megalapozza és igazolja a vezér forradalmi politikáját.

Az innováció és a karizmatikus kinyilatkoztatás (vízió), s így maga a vezetés három pontban nyilvánul meg. Egyrészt a karizmatikus vezetés új legitim rendet hoz létre (M. Weber 1987, p. 250). A vezér küldetését beteljesítve intuitív és proaktív módon új parancsokat, új reformot és akár új rezsimet is hirdet, alkot és követel. A változás mindig minőségi, s nem mennyiségbeli (Schumpeter 2006, pp. 81-86). Egy ilyen reform nem részletkérdéseket hangsúlyoz, hanem rendszerszintü változást céloz meg. Az emberek általános igazságérzete, a rend és kiszámíthatóság iránti vonzódása, nyers érzelmei (düh, irigység) számítanak döntő motívumnak. A valódi - pontosabban a vezér szempontjából valóban fontos - változás elsősorban a követőkben jelenik meg. A karizmatikus vezető „belülről”, érzelmek útján forradalmasít. Így a kérdés az, hogy a követők mennyiben képesek a vezér kinyilatkoztatását magukba fogadni, átélni és a vezér személyét támogatni. Mindazonáltal a vezér erényeinek megítélése mindig csak a folyamat végén értelmezhető: sikerült-e megoldani a kollektív problémákat, megteremtenie a rendet és a biztonságot, azaz beigazolódnia a karizmájának.

Másrészt az új rend kialakítása előfeltételezi a régi lerombolását. Schumpeter az innovációt olyan tevékenységként írja le, amely egy adott rendszeren belül hoz létre valami újat, és egyszersmind rombolja le a régit (creative destruction: Schumpeter 2006, p. 83). A gondolat mélyen gyökerezik a weberi gondolkozásban is, hiszen a karizma minden szabálytól és tradíciótól idegen (M. Weber 2009, pp. 347-51). A 
karizmatikus vezetés előtt elvárás, hogy szétzúzza, felforgassa a már meglévő rendet: a szabályokat, a tradíciókat és szentségeket. Ezzel válik a vezér a rend kizárólagos forrásává: „»ıírva vagyon, de én mégis mondom néktek«” (M. Weber 1987, p. 250). A kinyilatkoztatásban egyszerre jeleníti meg a víziót és a kötelesség kiszabását. Végeredményében a vezér a karizma birtokosaként új rezsimet alapít, azaz a kormányzás, a hatalomgyakorlás és a legitimitás egy új meghatározott módját alakítja ki (Illés, Körösényi, és Metz 2018). Így tevékenysége egyszerre rejti magában a régi rezsim lerombolását és egy új építését (Skowronek 1997, pp. 19-23).

Harmadrészt a vezér - ha adott esetben csak két választás közötti időszakban is - az egyetlen valódi politikai cselekvő. Ahogy azt aláhúztam korábban: a politikai küzdelem itt az állam irányításáért, kormányzásáért, a legitim erőszak monopol alkalmazásáért folyik. Könnyen belátható, hogy a pozíciók száma véges, és csak kevesek számára adott a pozíciók megszerzésének lehetősége. Azonban a vezér - mely megnevezést nem véletlenül használom egyes számban - nem türi meg a konkurenciát. A vezér képességeiben egyedülálló, saját rezsimet alapít és egyedül is áll a kormányzat élén. Ö a kiinduló- és végpontja a hatalomnak, a döntéseknek, de ő viseli a felelősséget is. Iránymutatásait el kell ismerni (M. Weber 1987, pp. 272). „Ilyenkor” kinyilatkoztatása nem megkérdőjelezhető, az az egyetlen helyes döntés. S bár a karizma nem a választás során keletkezik, az már előtte is meglévő adomány, azt nemcsak a többségnek, hanem mindenkinek el kell fogadnia. A karizma birtokosa, és az azt felismerők, támogatók szemszögéből ,az eltérő véleményen lévő választók tehát bünt követnek el” (M. Weber 2009, p. 342). Majd Weber hozzáteszi: ,a kisebbség erkölcsi »kötelességének« számít, hogy fejet hajtson a szavazás kimenetele folytán immár bebizonyosodott igazság előtt, és utólag csatlakozzék a többséghez" (M. Weber 2009, p. 342). A vezér nemcsak saját szavazóit képviseli, hanem meg kell testesítenie küldetése és ,áldozatvállalása” során az egész közösséget. A karizmatikus vezetés tehát az egész politikát kívánja átfogni és uralni. Ezért, aki nem fogadja el a vezetést, az politikai „ellenféllé” vagy akár „ellenséggé” válhat.

\subsubsection{A „helyes” kapcsolat a vezetők és a követők között}

Bár a vezérdemokráciában csökken az állampolgárok politikai jelentősége és beszükül a részvétel, mégis a követők és a követés szerepe kritikus marad. Az eddigiek alapján világos kép rajzolódhatott ki a követőkről és a velük kialakított kapcsolatról. A vezér kiemelése, a vezetők és követők között vertikális kapcsolatot, vagyis alá- és fölérendeltséget vetít elöre (4. szempont). A vezér kinyilatkoztat, a követők 
engedelmeskednek. A vezetők felhatalmazást kérnek a kormányzásra, a követők elismerik igényüket, felismerik karizmájukat. A vezetőknek nem egyszerüen hatalmuk van követöik fölött, hanem a követök felhatalmazása nyomán és saját képességeik révén hatalmukban áll valamit megtenni (power to) (szempont 3.), amire hatalom nélkül nem lennének képesek. A követők mobilizálásának, az alkalmasság bizonyításának és egy új rend kialakításának az eredményeként tehát a vezetők egyenesen létrehozzák és kreálják maguknak a hatalmat. A politikai kompetenciákat és tudást érintő aszimmetriának az aláhúzásával azt is állítottam, hogy a hivatásos politikusok, vezetők kezdeményezőként, proaktív félként alakítják a politikát (szempont 5.). Ez azonban nem egyszerü szükségszerüség, hiszen a felhatalmazás során a követők (formálisan) szabadon le is mondanak a cselekvésről a vezér javára abban a határozott reményben, hogy ö majd a vélt vagy valós problémáikat hatékonyan orvosolja.

Az „egyoldalú” viszony képe azonban csalóka. A demokratikusan gyártott karizmatikus vezetés számára kritikus a követők csoportja, a karizmatikus közösség vagy mozgalom megléte (Kalyvas 2008; Tucker 1968). Itt a követők nem elsősorban időtlen univerzális értékekhez, ideákhoz vagy magas morális célokhoz, de nem is pozíciókhoz és procedúrákhoz, és az azoknak tulajdonított értékekhez, hanem közvetlenül a vezér személyéhez kötődnek. Nem a morális bizonyosságot (igazságot), vagy a cserealapú bizalmat, hanem a személyes biztonságot keresik, amelyet csak a vezér képes megadni. Mégsem válnak teljesen kiszolgáltatottá a követők, ugyanis a vezér a kegyelmükből kormányoz, akit az:

„alávetettek (formálisan) szabadon választanak, tetszésük szerint emelnek hatalomra, és akit esetleg meneszthetnek is; ugyanúgy, ahogy a karizma elvesztése - illetve az, ha nem igazolódott be - már korábban is az eredeti legitimitás elvesztését vonta maga után. Az úr most szabadon választott vezér. (...) [F]ormálisan mindenképpen ez a megfelelö eszköz arra, hogy az alávetettek (formálisan és a fikció szerint is) szabadon kinyilvánított bizalmából lehessen levezetni az uralom legitimitását.” (kiemelés az eredetiben) (M. Weber 1987, p. 272)

A követők a szabad választás ellenére teljesen alávetik magukat a vezérnek, amely azonban a biztonság érzetén túl önértékkel is bír számukra. Ugyanis a „vezérért dolgozni önmagában véve is nagy belső megelégedést jelent” (M. Weber 1989, p. 47). Ahogy tehát a vezetést, úgy a követést is belső érzelmi elhivatottság jellemzi. $\mathrm{S}$ ez a 
személyes kitettség, függőségi viszony teszi különösen bizonytalanná kapcsolatukat és kritikussá a vezető személyét. Mindennek három következményét kell aláhúzni.

Egyrészt a karizmával felruházott vezért mindig a természetes érzelmekből fakadó odaadás övezi, és ő ennek megfelelően vakhitet és engedelmességet vár el a követőktől. Azaz: egy karizmatikus közösség mindig érzelmi alapon szerveződik. Weberi kategóriákban gondolkodva és a schumpeteri infantilizmus-érvét előhívva itt a követők cselekvése elsősorban indulati, emocionális. A követők a ténylegesen meglévő vágyaikat elégítik ki, félelmeiket élik meg: bosszút állnak, élvezetet szereznek maguknak, odaadást tanúsítanak, belefeledkeznek a szemlélődésbe, vagy levezetik indulataikat (M. Weber 1987, p. 53). A követöknek egyenként nem kell racionálisnak lenniük, de közös cselekvésüknek a vezér szemszögéből értelmesnek kell lennie. A vezérnek fel kell oldania a konfliktusokat, az érzelmi feszültségeket. Pontosabban a közösségi értékek megtestesítésével, célok kijelölésével kollektív szinten kell racionalizálnia a követők cselekvését. A követők olyan, a vezértől közvetlenül származó, vagy neki tulajdonított parancsokat követnek, amelyekröl úgy gondolják, hogy személy szerint nekik szólnak. A közös cselekvés értelemmel telítődik, azonban az indulati, érzelmi és irracionális jelleg még így is megkerülhetetlen. A követök nem láthatják a következményeket, és így azokért nem is vállalhatják a felelősséget.

Másrészt a karizmatikus vezetés nem válik el a közösség értékeitől. Olyan értékeket és célokat fogalmaz meg, amelyek a közösség jó(l)létében, biztonságában és fennmaradásában csúcsosodik ki. A vezér megfogalmazza és megtestesíti a közösség értékeit, amellyel egyszerre válik a közösség védelmezőjévé és identitásának forrásává. A vezető tehát nem csak érzelmi, de értékközösséget is teremt követőiből. Így itt az eddigiektől eltérően a követők köre egy egész közösséget (nemzetet, osztályt) lefedd. A karizmatikus vezetés, mint az identitás forrása jelenti a politikai kötelesség alapját. Ennélfogva a közösség határainak kijelölése, az azon kívüliek meghatározása, a „mi” és az „ők” elhatárolása is különösen fontossá válik.

Végül látni kell azt is, hogy az erős, egy személyben összpontosuló vezetés nem jelent korlátlan, ,abuzív” hatalomgyakorlást és erőszak-alkalmazást. Weber rámutat, hogy a fegyelmezés beszükíti a karizmát és eltünteti az egyéni különbségek jelentőségét a politikai cselekvésben (M. Weber 2009, p. 417). A fegyelmen alapuló modern hadseregek, gazdasági nagyüzemek és a bürokratikus államigazgatás mind-mind hozzáidomítják a cselekvőket a követelményekhez és a feladatokhoz. Így a fegyelem elkerülhetetlenül: 
„háttérbe szorítja a hősi eksztázisba eső egyén szerepét, a tiszteletet, a vezér személye iránt megnyilvánuló rajongó lelkesedést és odaadást, a »becsület« kultuszát, a személy teljesítményeinek és a személyes képességeknek, mint valamiféle »mủvészetnek« az ápolását, és a »kiképzést«, a »begyakorlással« kialakított és gépiessé vált készséget, valamint - amennyiben egyáltalán hivatkozik erős »etikai« jellegü indítékokra - a »kötelességet« és a »lelkiismeretességet« állítja a helyükre.” (M. Weber 2009, p. 406)

Ez azt jelenti, hogy a karizma előállítása, felismerése és a kötelesség igazolása nem lehet automatikus, nem lehet kikényszeríthető. Azok a vezetők, akik erre törekednek, a hatalmat öncélúan hajszolják és így őket csupán a politikai hiúság vezérli.

A vezérválasztás szabadságának weberi kitétele itt válik igazán fontossá. A fegyelem mint a tervszerü, kötött cselekvés, és mint a nyers hatalomgyakorlás hordozója - kizárja az egyéni kritikát, pontosabban a karizma megkérdőjelezését és ezzel értelmetlenné teszi annak beigazolódását. Amely karizmának nem kell beigazolódnia, amely karizmát nem lehet megkérdőjelezni, az logikailag és fogalmilag elképzelhetetlen vagy éppenséggel megszünik karizmának lenni. S a vezérdemokrácia, amely a vezér ideája köré épül, ezen a ponton húzza meg azt a határt, amely után megszünik a vezetés és a politika. A követők számára a karizma elfogadása nem lehet tehát kényszer, viszont, akik nem ismerik el a karizma birtokosát „természetes” módon, könnyen kiszorulhatnak a karizmatikus közösségből, s így számukra megkérdőjeleződik a vezetés. Ez azonban csak akkor válik igazán láthatóvá, ha feltűnik kihívóként a karizmának egy új birtokosa.

\section{3. Összegzés}

A vezérdemokrácia a demokratikus politika egy tisztán politikai értelmezését adja. A demokrácia ebben az elméleti keretben pusztán módszert, eszközt helyez a választók kezébe a kormányzásra alkalmas vezetők kiválasztására. A vezérdemokrácia jelentősen pesszimistább képet tár elénk az állampolgárok politikai kompetenciáiról és preferenciáinak súlyáról. A valódi politikai cselekvés csak kevesek kiváltsága lehet. A hivatásos politikusok (a vezetők) azok, akik valódi politikai akarattal és érdekekkel rendelkeznek, akik mozgatják a politikát. A politikai verseny az államirányítás, a legitim hatalmi monopóliumért folyik. Túl azon, hogy a demokratikus politikának a célja a jó kormányzás révén a vélt vagy valós kollektív problémák megoldása, a politikai folyamatnak csak terméke a közérdek, amelyet végső soron a vezetők állítanak elő. Mindazonáltal az állampolgárok nem kerülnek ki a demokratikus politika keretei közül, csak a korábban tárgyalt elméletekhez viszonyítva eltérő szerepben jelennek 
meg. A politikai részvétel tartalmát illetően bár beszükül, de fontos szerepet játszik a demokratikus politikában. A polgárok alkalmi politikusként hol passzív, hol aktív módon beleegyezésüket adják a kormányzásba és felhatalmazzák a vezetőket.

Az elmélet a vezér tevékenységét, a karizmatikus vezetést nemcsak középpontjába helyezi, de egyenesen a demokratikus politikával azonosítja. A politikát természeténél fogva bizonytalanság jellemzi, ennélfogva a karizmatikus vezetés előtt legfőbb kihívásként ennek a bizonytalanságnak az uralása, azaz a kollektív problémák leküzdése áll. A demokratikus politika és a vezetés célja tehát azonossá válik. Mindehhez egyfelől a vezérnek bizonyítania kell alkalmasságát: különleges képességeit, erényeit, gyakorlati tudását (döntésképességét, cselekvőképességét). Ez az igény a követők elismerésére a karizmájának az alapját is jelenti. Másfelől a vezérnek víziót, innovációt, változást kell meghirdetnie. A régi rendet le kell rombolnia és ki kell alakítania egy új rendet. A bizonytalanságot uraló vezér - aki nem tür meg vetélytársat - lesz a biztos pont a közösség életében. A követők szorosan és érzelmi alapon kötődnek vezérükhöz, akinek teljesen alávetik magukat. Ennélfogva a vezér egymagában a politika és a közösség egyedüli forrása. A karizmatikus vezetés egyedüli korlátja abban áll, hogy a követés az engedelmesség, a karizma fel- és elismerése, illetve a vezér felhatalmazása - nem kikényszeríthető, hiszen szükségtelenné teszi a karizma beigazolódását és kiüresítené a karizmatikus kapcsolatot a vezér és követői között. 


\section{6. ÖSSZEGZŐ GONDOLATOK: A DEMOKRATIKUS VEZETÉS TIPOLÓGIÁJA}

A disszertáció első részében arra a kérdésre kerestem a választ, hogy milyen implicit elméletek keretében lehet a demokratikus vezetésről gondolkodni. Három kiválasztott demokráciaelméletből levezetve a demokratikus vezetés három értelmezését alakítottam ki. Ehhez először rendeztem a demokráciaelméletek premisszáit a politika bemeneti - és kimeneti oldalára, illetve folyamatára fokuszálva. Ezt követően a felállított elméleti keretben kerestem a vezetés helyét, pontosabban azt, hogy a vezetés, mint a demokrácia gyakorlata, miként járul hozzá a demokratikus politikához. Az implicit elméleteket a „jó” vezetés, valamint a vezetők és követők közötti „helyes” kapcsolat dilemmájából kibontott öt (kihívások, politikai tudás, hatalmi kapcsolat, interakciók, valamint a vezetők és követők szerepe) szempont mentén tártam fel. Az így felállított vezetéstípusok együttesen alkotják a demokratikus vezetés tipológiáját. Röviden tekintsük át most az első rész eredményeit!

A demokrácia három különböző ideáját, a deliberatív-részvételi demokrácia morális-, az aggregatív- pluralista demokrácia materiális- és a vezérdemokrácia politikai koncepcióját jártam körbe. A deliberatív-részvételi demokrácia azt a normatív célt fogalmazza meg, hogy növelni kell az állampolgári kontrollt a döntések felett, és az állampolgárok autonómiáját a politikában. Alacsonyabbra helyezve az elvárásokat, az aggregatív-pluralista demokrácia központi problémájaként már az merül fel, hogy miként lehet a preferenciákból kormányprogram vagy közpolitika, illetőleg miként lesz az érdekekből hatalom, hatalmi tényező úgy, hogy a demokratikus keretek ne sérüljenek. A vezérdemokrácia elméleti keretében viszont a demokrácia már csak egy módszer, egy eszköz a kormányzásra alkalmas vezetők kiválasztására. Áttekintve az elméleteket, rámutattam azokra az alappremisszákra (1. táblázat), amelyek mentén azok megkonstruálják és igazolják demokráciaképüket. 
1. táblázat: A demokrácia három értelmezése

\begin{tabular}{|c|c|c|c|}
\hline & $\begin{array}{l}\text { Deliberatív-részvételi } \\
\text { demokrácia } \\
\text { (a demokrácia morális } \\
\text { értelmezése) }\end{array}$ & $\begin{array}{c}\text { Aggregatív-pluralista } \\
\text { demokrácia } \\
\text { (a demokrácia materiális } \\
\text { értelmezése) }\end{array}$ & $\begin{array}{c}\text { Vezérdemokrácia } \\
\text { (a demokrácia politikai } \\
\text { értelmezése) }\end{array}$ \\
\hline \multicolumn{4}{|c|}{ Bemeneti oldal } \\
\hline Katalizátor & $\begin{array}{c}\text { közvetlen, nem } \\
\text { konvencionális részvétel }\end{array}$ & $\begin{array}{l}\text { közvetett, konvencionális } \\
\text { részvétel }\end{array}$ & $\begin{array}{c}\text { a vezetés, mint a } \\
\text { részvétel egy } \\
\text { megkülönböztetett } \\
\text { formája }\end{array}$ \\
\hline Állampolgárok & $\begin{array}{l}\text { közérdek-orientáltak, } \\
\text { racionálisak, } \\
\text { kompetensek és } \\
\text { informáltak }\end{array}$ & $\begin{array}{c}\text { önérdek-orientáltak, } \\
\text { racionálisak, } \\
\text { kompetensek, de } \\
\text { korlátozottan informáltak }\end{array}$ & $\begin{array}{l}\text { önérdek-orientáltak, } \\
\text { irracionálisak, } \\
\text { inkompetensek és nem } \\
\text { informáltak }\end{array}$ \\
\hline Preferenciák & ex-post & ex-ante & ex-post \\
\hline \multicolumn{4}{|c|}{ A folyamat } \\
\hline Iránya* & bottom-up & bottom-up & top-down \\
\hline Tartalma & $\begin{array}{l}\text { a preferenciák } \\
\text { többoldalú alakítása } \\
\text { (deliberáció) }\end{array}$ & $\begin{array}{c}\text { a preferenciák } \\
\text { mechanikus összegzése } \\
\text { (reszponzív politika: } \\
\text { aggregáció és képviselet) }\end{array}$ & $\begin{array}{l}\text { a preferenciák egyoldalú } \\
\text { alakítása (monopolista } \\
\text { verseny és manipulálás) }\end{array}$ \\
\hline \multicolumn{4}{|c|}{ Kimeneti oldal } \\
\hline $\begin{array}{l}\text { Szavazás } \\
\text { szerepe* }\end{array}$ & $\begin{array}{c}\text { másodlagos, de } \\
\text { elkerülhetetlen: a } \\
\text { deliberáció időleges } \\
\text { lezárása }\end{array}$ & $\begin{array}{l}\text { elsődleges: a preferenciák } \\
\text { formális összegzése }\end{array}$ & $\begin{array}{l}\text { elsődleges: a vezetők } \\
\text { kiválasztása, } \\
\text { felhatalmazása és } \\
\text { leváltása }\end{array}$ \\
\hline Eredmény & $\begin{array}{l}\text { mindenki által } \\
\text { elfogadható méltányos } \\
\text { döntés (a konszenzus } \\
\text { állandó keresésével) }\end{array}$ & $\begin{array}{l}\text { aggregáción alapuló } \\
\text { kompromisszum } \\
\text { (többségi döntés) }\end{array}$ & $\begin{array}{l}\text { kollektív problémák } \\
\text { megoldása (ellenkező } \\
\text { esetben a vezető } \\
\text { leváltásra kerül) }\end{array}$ \\
\hline
\end{tabular}

* Pakulski és Körösényi 2012, p 100 alapján

A demokratikus politika bemeneti oldalán arra voltam kíváncsi, hogy $k i$ a politikai cselekvés alanya és $m i$ indítja be a politikai folyamatot. A politikai folyamat katalizátora minden esetben a politikai részvétel, amíg azonban az a deliberatív-részvételi demokrácia elméleti keretében elsősorban nem konvencionális és közvetlen, amelyet szélesíteni ajánlatos, addig az aggregatív-pluralista demokráciában az állampolgárok már csak konvencionális és formális módon, a politikusokon keresztül indítják be a politikát, s részvételük szintjének növelése nem feltétlenül szükséges. Ezzel szemben a vezérdemokráciában a politikai folyamatot a vezetés - mint a részvétel egy megkülönböztetett formája - indítja be. Itt bár a vezetők, vezérek kiváltsága a valódi politikai hatással járó részvétel, mégis szükségesnek tünik a vezetők felhatalmazása és leváltása kapcsán az állampolgárok passzív, és időnkénti aktív hozzájárulása a politikai folyamathoz. Az állampolgárokról, ennek megfelelően, eltérő kép rajzolható fel. Amíg a deliberatív-részvételi demokráciában a politika közérdek-orientált, racionális, 
kompetens és informált állampolgárokat feltételez, addig az aggregatív-pluralista demokrácia már pesszimistább az informáltságot illetően, és az önérdekkövetést hangsúlyozza. A vezérdemokrácia nyújtja a legpesszimistább képet az állampolgárokról, amikor kompetenciájukat és tudatosságukat tekintve megkülönbözteti őket a hivatásos politikusoktól. A politika minden esetben az állampolgári preferenciák „körül” szerveződik, ugyanakkor ezek a deliberatív-részvételi- és a vezérdemokrácia politikaképe szerint a folyamat során változnak, ellenben az aggregatív-részvételi elmélet adottnak veszi azokat.

A demokratikus politika folyamatának vizsgálata során arra fókuszáltam, hogy az hogyan köti össze a politika alanyait annak folyamatával. Az első két elméleti keret egyaránt alulról felfelé épülő (bottom-up) folyamatot ír le, amely a közérdek kialakulásában és kialakításában merül ki. Amíg azonban a deliberatív-részvételi demokrácia a deliberációban a preferenciák többoldalú alakítását látja, addig az aggregatív-pluralista demokrácia azok mechanikus összegzését - aggregációját és képviseletét - feltételezi, kiemelve a politikai szereplők reszponzivitásának kívánalmát. A vezérdemokrácia mindezzel szemben a közérdek kialakítását egy felülről lefelé irányuló (top-down) politikai folyamatként írja le, amelyet a politikai vezetők monopolista versenye és a preferenciák egyoldalú alakítása, befolyásolása és manipulációja határoz meg.

A demokratikus politika kimenetelét tekintve a folyamat céljára mutattam rá; pontosabban arra, hogy a politika miért is zajlik. A szavazás intézménye a deliberatívrészvételi demokráciában másodlagos, de elkerülhetetlen a deliberáció időleges lezárásakor. A politika itt egy mindenki által elfogadható, méltányos döntést eredményez, amely később is megkérdőjelezhető marad. Ez azt jelenti, hogy az elmélet számára a konszenzus állandó, de mégis elérhetetlen cél lesz. Az aggregatív-pluralista demokrácia számára viszont a preferenciákat formálisan összegző szavazás egyenesen a kompromisszumot biztosító aggregatív döntést jelenti, amelynél fogva szerepe elsődleges. A vezérdemokrácia számára a vezetők kiválasztása, felhatalmazása és leváltása szempontjából válik fontossá a szavazás. A politika kimenetele mégsem ez, hanem a kollektív problémákat orvosolni kívánó ,jó” kormányzás.

A különböző demokráciafelfogások a vezetés más-más formáját igénylik (jó vezetés), s különféle kapcsolatokat írnak le/elö a vezetök és a követök között (helyes kapcsolat). Ezzel a vezetés három lehetséges értelmezését, implicit elméletét alkottam meg (2. táblázat), amely a maguk értelmezési keretében „erős” vezetést jelentenek, és nemhogy 
nem veszélyeztetik, de inkább erősítik, elősegítik a demokráciát. A vezetéstípusok különbözőképp járulnak hozzá a demokratikus politikához. Másképp fogalmazva: a demokrácia különböző gyakorlatát írják le. A felállított öt szempont mentén jól kivehetővé vált, hogy a különböző demokráciaelméletek mekkora, egymástól eltérő mértékű teret engednek meg, s milyen korlátokat és feladatokat szabnak meg a politikai vezetés számára.

A deliberatív-részvételi demokráciában a transzformatív vezetés érvényesülhet, amely előtt kihívásként egyfajta „morális alapítás” áll (1. szempont). Ez kiterjed a demokratikus keretek kialakítására és a politika megfelelő módjának fenntartására. E demokráciafelfogásban - természetéből fakadóan - az alapítás kihívása állandósul, amelyet három mozzanatban határoztam meg. Az első a morális iránymutatás volt. Ehhez a vezetőnek abszolút és univerzális elméleti tudásra (episztémé) van szüksége (2. szempont), amely képessé teszi arra, hogy az ,igazságot” keresse, azaz a megfelelő kérdéseket tegye fel; illetőleg arra, hogy az ,igazságot” közvetítse, azaz meghatározza a közös gondolkodás mikéntjét. A cselekvés értékracionális és így elsősorban az érzületetika dimenziójában ítélhető meg. Egy másik mozzanat a vezető számára, hogy konstruktív és adaptív módon a deliberáció folyamatán keresztül kezelje a problémákat és a konfliktusokat, amelyhez elengedhetetlen a kívánt kényszermentes, kölcsönös tiszteleten, elismerésen és reciprocitáson alapuló kommunikáció elősegítése és fenntartása. A harmadik mozzanat a követők politikába történő beemelése, felhatalmazása (empowerment), hogy ők is a folyamat részeseivé és akár vezetőivé válhassanak. Összességében a transzformatív vezetés lehetővé teszi a részvételt és a deliberációt (a preferenciák többoldalú alakítását), s ezt támogatva neveli és transzformálja a követőket és elősegíti a preferenciák racionalizálását és konvergálását, $\mathrm{s}$ végül, de nem utolsósorban a mindenki által elfogadható méltányos döntést. Ennek eredményeképp a vezetők és a követők szerepei gyakran felcserélődhetnek, s együtt gyakorolják a hatalmat (power with) (3. szempont). A vezetök és követők közötti interakciók horizontális pályát (4. szempont) írnak le, amelyben mindkét fél koaktív (kölcsönösen aktív) szereplővé válik (5. szempont). Kapcsolatuknak bizonyos végső értékeken és magán a részvételen kell nyugodnia. Ennek alapján kijelenthető, hogy a teljes és valós közvetlen állampolgári részvétel, és így a bottom-up politikai folyamat, amelyet a deliberatív-részvételi demokrácia elöír, előfeltételezi a transzformatív vezetést. 
2. táblázat: A vezetés három lehetséges értelmezése a demokráciában (a demokratikus vezetés tipológiája)

\begin{tabular}{|c|c|c|c|}
\hline & $\begin{array}{c}\text { Deliberatív-részvételi } \\
\text { demokrácia }\end{array}$ & $\begin{array}{c}\text { Aggregatív-pluralista } \\
\text { demokrácia }\end{array}$ & Vezérdemokrácia \\
\hline \multicolumn{4}{|c|}{ A ,jón” vezetés } \\
\hline $\begin{array}{l}\text { 2. szempont: } \\
\text { Politikai } \\
\text { tudás** }\end{array}$ & $\begin{array}{c}\text { transzformatív vezetés } \\
\text { (a demokratikus vezetés } \\
\text { morális koncepciója) } \\
\text { „morális alapítás” } \\
\text { - morális iránymutatás } \\
\text { - konstruktív } \\
\text { problémamegoldás } \\
\text { - követök beemelése a } \\
\text { politikába (empowering) } \\
\text { episztémé } \\
\text { (elméleti, filozófiai } \\
\text { tudás) }\end{array}$ & $\begin{array}{c}\text { tranzaktív vezetés } \\
\text { (a demokratikus vezetés } \\
\text { materiális koncepciója) } \\
\text { „politikacsinálás” } \\
\text { - politikai részvétel } \\
\text { biztosítása } \\
\text { - a közérdek kialakítása } \\
\\
\text { tekhné } \\
\text { (technikai, produktív } \\
\text { tudás) }\end{array}$ & $\begin{array}{c}\text { karizmatikus vezetés } \\
\text { (a demokratikus vezetés } \\
\text { politikai koncepciója) } \\
\text { „bizonytalanság leküzdése” } \\
\text { - alkalmasság } \\
\text { bebizonyítása } \\
\text { - új rend kialakítása } \\
\text { (kinyilatkoztatás/innováció, } \\
\text { régi rend lerombolása, } \\
\text { vezérség, mint } \\
\text { monopólium) } \\
\text { praxisz } \\
\text { (gyakorlati tudás) }\end{array}$ \\
\hline \multicolumn{4}{|c|}{ A „helyes" kapcsolat } \\
\hline $\begin{array}{l}\text { 3. szempont: } \\
\text { Hatalmi } \\
\text { kapcsolat } \\
\text { 4. szempont: } \\
\text { Interakciók } \\
\text { iránya* } \\
\text { 5. szempont: } \\
\text { A vezetők és a } \\
\text { követők szerepe }\end{array}$ & $\begin{array}{c}\text { a hatalom kollektív } \\
\text { gyakorlása (power with) } \\
\text { (empowerment) } \\
\text { horizontális } \\
\text { (értékalapú kapcsolódás) }\end{array}$ & $\begin{array}{c}\text { a hatalom mások felett } \\
\text { gyakorlása (power over) } \\
\text { (domination) } \\
\text { vertikális } \\
\text { (érdekalapú } \\
\text { kapcsolódás) }\end{array}$ & $\begin{array}{l}\text { a hatalom valaminek a } \\
\text { megtételére (power to) } \\
\text { (authorization) } \\
\text { vertikális } \\
\text { (érzelmi kapcsolódás) }\end{array}$ \\
\hline
\end{tabular}

* Pakulski és Körösényi 2012, p. 100 alapján

** Körösényi 2005, p. 239 alapján

Az aggregatív-pluralista demokrácia elmélete a tranzaktív vezetést írja elő, amelynek célja a „politikacsinálás” (1. szempont), azaz: a preferenciák aggregálásának és képviseletének a megvalósítása, valamint a kompromisszum kialakítása. Leegyszerüsítve a vezetésnek össze kell kapcsolnia az egyéni preferenciákat, a közösségi érdekeket a kormányzással. Ezt két mozzanatban fogtam meg: egyrészt a vezetésnek szükséges, a közjavak létrehozása és a preferenciák kifejezése céljából fenntartani a kollektív cselekvést; másrészt a vezetésnek ki is kell alakítania a közérdeket, a közakaratot megtestesítő politikát. A vezető számára szelektív ösztönzők, és kemény hatalmi - és a preferenciákat közvetetten befolyásoló eszközök állnak a rendelkezésére, amellyel közvetve képes a politikát „finomhangolni”. A megfelelő eszközök kiválasztásához és alkalmazásához elsősorban technikai tudásra (tekhné) (2. szempont) van szükség, amelynek birtokában a vezető „gépészként” legyártja a 
közérdeket az eleve adott preferenciákból és üzemelteti a politika gépezetét. A vezető cselekvése célracionális, amelynek a megítélése a felelősségetika keretében történik. Tehát önérdekéből fakadó céljaihoz úgy rendel eszközöket, hogy közben érvényesíti a közérdeket, nem rúgja fel a demokratikus játékszabályokat és tiszteletben tartja az intézményeket övező (modális) értékeket. Ezt a tudást azonban bárki elsajátíthatja. A vezető rendelkezik ugyan a legnagyobb befolyással, hatalommal is a követöi felett (power over) (3. szempont), mégis ki van szolgáltatva az intézmények és procedúrák által becsatornázott követői akaratnak és preferenciáknak. Mivel a követök így nem veszítik el kezdeményezőképességüket, a vezetők reaktív szerepbe kényszerülnek (5. szempont). Összességében a vezetők és a követők közötti cserealapon szerveződő érdekkapcsolat hierarchikus, vertikális (4. szempont), de a két fél kölcsönösen függ egymástól. Így a politikai folyamat bottom-up jellege és a vezető kiemelt szerepe (hatalmi kapcsolat, vertikális interakciók) is megmarad.

A vezérdemokrácia a különösen hatékony, karizmatikus vezetés képét idézi meg, amely képes kezelni a vélt vagy valós kollektív problémákat és leküzdeni a politikában rejlő bizonytalanságot. Ezzel lényegében ebben a keretben a demokratikus politika és a vezetés célja azonossá válik. Két mozzanatban foglaltam össze ezt a kihívást ( 1 . szempont). Az első értelmében a vezérnek bizonyítania kell alkalmasságát a kormányzásra. Ehhez egyfelől erősen kontextus-függő erényekkel (arányérzékkel) és gyakorlati tudással (praxizs) (2. szempont) kell rendelkeznie, melyek képessé teszik a vezetőt, hogy felelősen döntsön, és céljai érdekében cselekedjen. Másfelől a vezető e képességeit (karizmáját) a követőknek fel- és el is kell ismerniük. A második mozzanat szerint a vezérnek karizmatikus kinyilatkoztatására, víziójára és innovációjára alapozva új rendet kell létrehoznia, amely a régi rend lerombolását vonja maga után. Ebböl következően a vezér - aki nem tür meg vetélytársakat - „biztos” pontként, egymaga válik a közösség forrásává. Bár az állampolgárok politikai szerepe és részvétele a vezérdemokrácia elméleti keretében másodlagos, mégis a követés különösen fontos momentummá válik. A vezér érzelmi és értékközösséget teremt követőiből. A követők közösségként szorosan, érzelmi alapon kötődnek vezérükhöz, akinek - politikai értelemben teljesen - alávetik magukat, és akit felhatalmaznak a cselekvésre (power to) (3. szempont). Kapcsolatuk így elkerülhetetlenül vertikális (4. szempont), melyben a vezér szerepe proaktív, míg a követők reaktívvá válnak (5. szempont). A karizmatikus vezetést egyedül az korlátozza, hogy a követés fegyelmezéssel (erőszakkal) nem kikényszeríthető, hiszen annak a karizma fel- és elismerésén, valamint érzelmi odaadáson kell nyugodnia. 
Összességében a disszertáció első részében a demokratikus vezetés implicit vezetéselméleteinek feltárásával kialakítottam egy vezetéstipológiát. Közelebbröl szemügyre véve a demokratikus politika eltérő felfogásait szembetünővé vált, hogy követve a demokráciaelméletek elvárásait és premisszáit a vezetés mindegyikben kritikus szerepet játszik és járul hozzá a politika folyamatához. Saját elméleti kontextusukban steril módon ugyan, de koherens képet jelenítenek meg, amelyekben összesürüsödnek a demokratikus vezetés irányában megfogalmazható elvárások. Ennek megfelelően a demokratikus vezetés kapcsán is morális -, materiális - és politikai koncepcióról beszélhetünk. Erre alapozva ezen átfogó tipológia lehetővé teszi a konkrét vezetési gyakorlatok plurális olvasatát és értelmezését a demokráciákban és így alkalmasnak tünik arra, hogy a disszertáció második részében heurisztikai eszközként segítse az empirikus elemzést. 


\section{MÁSODIK RÉSZ:}

\section{A DEMOKRATIKUS VEZETÉS GYAKORLATI KONSTRUKCIÓI}

„,Vesd össze gondosan az eszmét a szavakkal. Mélyedj elméddel az eseményekbe és okaikba" Marcus Aurelius (1983, p. 95)

„A szavak is tettek, és a tettek is egyfajta szavak.” Ralph Waldo Emerson (1844, p. 9) (ford. tőlem) 


\section{7. \\ AZ EMPIRIKUS ELEMZÉS SZEMPONTRENDSZERE ÉS MENETE}

$\mathrm{Az}$ első részben három demokráciaelméleti keretben értelmeztem a demokratikus vezetést. Arra voltam kíváncsi, hogy a demokratikus politikával szembeni elvárások kontextusában miként lehet a vezetésről gondolkodni. A különböző premisszákra épülő demokráciaelméletekből eltérő implicit vezetéselmélet olvasható ki, amelyek egy heurisztikai eszközként szolgáló tipológiában álltak össze. Minden absztrakt elméleti konstrukció azonban csak addig a pillanatig lehet hasznos, ameddig az segíti a kutatónak a világot értelmezni és megérteni.

A demokratikus vezetés gyakorlati problematikájának kapcsán azt a kérdést fogalmaztam meg, hogy miként konstruálódik meg a demokratikus vezetés a gyakorlatban, pontosabban: a vezetö miként tudja létrehozni a maga demokratikus valóságát és gyakorlatát, miként igazolja és fogadtatja el saját tevékenységét. Az elemzés során a vezetéstípusok viszonyítási pontokként, heurisztikai eszközként fognak szolgálni, lehetőséget adva az adott demokratikus vezetés plurális olvasatára. Egy-egy konkrét demokratikus vezetéskonstrukció úgy jön létre, hogy elkerülhetetlenül egyik vagy másik pozícióhoz fog közelebb kerülni. Mindazonáltal nem várható el, hogy a vezetők expliciten értelmezzék saját szerepüket és cselekvésüket az elméletek keretében leírt absztrakt kategóriák szerint. Ezért ezeket a vezetéskonstrukciókat a gyakorlat felől közelítem meg és közvetett módon tárom fel bennük a vezetéstípusokra mutató elemeket.

A demokratikus vezetés ezen a szinten már nem gondolati (elméleti) konstrukció, hanem olyan komplex történet-elmesélési folyamat, gyakorlati konstrukció, amely magában foglalja a vezető retorikai és performatív cselekvését is. A vezetés gyakorlati konstrukcióinak a leírásához Grint (2001, 2005b) által alkalmazott elemzési síkokat fogom segítségül hívni. Grint értelmezésében a vezetésnek öt kérdésre kell választ adnia: Kik vagyunk? Hol vagyunk? Mit szeretnénk elérni? Hogyan szeretnénk azt elérni? Miért kívánják a követők mindezt elfogadni? Mindebből öt elemzési sík rajzolódik ki: az identitásépítés, a helyzetdefiniálás, a vízióalkotás, a taktikaalkotás és a követők mobilizálása. 
Ahogy azt korábban már aláhúztam, ezen öt aspektus mentén strukturált elemzés három módon járul hozzá a kutatás egészéhez. Egyrészt az elemzési síkok összefogják a vezetés retorikai (wordcraft) és a performatív (stagecraft) elemeit, amelyek együttesen adják a vezetés gyakorlatát. Így egységes képet kaphatunk a vezetés adott gyakorlati konstrukciójáról. Másrészt az elemzés egyaránt bevonja a vezetőt és a követőket is az elemzésbe. Ezzel egyfelől koherens és átfogó kép alakítható ki a vezetésről, szem elől nem tévesztve a fogalom denotációjában gyökeret verő elemeit. Másfelől, így a vezetői történetelmesélés nem kerül névértéken való elfogadásra, hiszen visszacsatolásként a vezetés értékelését a mobilizálás hatásosságához mérten, a követők végzik el. A követők aktívan vagy passzívan nyilvánítanak véleményt a vezető által felmutatott vezetésröl és a vezető hitelességéröl. Harmadrészt a történetek átlátható módon történő rendezésével lehetővé válik a vezetéstípusok elemeinek kiemelése, a tipológiába való besorolás és a vezetők összehasonlítása. A vezetés minden gyakorlati konstrukciójából kiolvasható valamilyen válasz a fentebb megfogalmazott öt kérdésre, amelyből kikövetkeztethetők vagy leszürhetők a vezetéstípusokra jellemző elemek és vonások. Sőt az elemzési síkok mentén feltárhatók a vezetéstípusok absztraktabb elemei és az esetek látensebb jellegzetességei is.

Az alábbi fejezet célja összekötni a disszertációkutatás elméleti és empirikus szakaszait. Mivel a vezetés empirikus elméleti eseteit a gyakorlat felöl közelítem meg, ezért elengedhetetlen először tisztázni, hogy a grinti elemzési síkok a vezetéstípusok mely szempontjára mutathatnak rá. Ezt követően tisztázom az empirikus elemzés menetét, módszereit és forrásait.

Tekintsük át tehát, hogy az egyes elemzési síkok a demokratikus vezetés mely elemeit és szempontjait hozhatják a felszínre a jó vezetés és a vezetők és követők helyes kapcsolatának dilemmája mentén (3. táblázat).

(1) Identitásépités. A vezetés, mint társadalmi jelenség, elképzelhetetlen vezetők és követők nélkül. A vezetők nem saját, hanem a követőik nevében cselekszenek. A vezetők identitást hoznak létre „képzeletbeli” közösségüknek (Grint 2001, p. 6), amelyben meghatározzák a cselekvés alanyát, elválasztják a közösség tagjait és az azon kívül esőket. Mindezek nyomán a vezetők nem csak választ kínálnak arra a kérdésre, hogy „Kik vagyunk?”, de meg is határozzák a követők vezetésben betöltött - proaktív, reaktív vagy épp koaktív - szerepét. 
3. táblázat: Az empirikus elemzés síkjai és kapcsolódásuk a vezetéstípusok szempontjaihoz

\begin{tabular}{|c|c|c|}
\hline & Jó vezetés & Helyes kapcsolat \\
\hline $\begin{array}{l}\text { 1. Identitásépítés } \\
\text { (Kik vagyunk?) }\end{array}$ & - & $\begin{array}{l}\text { Követők szerepe: } \\
\text { Milyen szerepet kapnak a követők } \\
\text { a vezetés folyamatában? }\end{array}$ \\
\hline $\begin{array}{l}\text { 2. Helyzetdefiniálás } \\
\text { (Hol vagyunk?) }\end{array}$ & $\begin{array}{l}\text { Kihívások: } \\
\text { Milyen kihívások előtt áll a } \\
\text { vezetés? }\end{array}$ & - \\
\hline $\begin{array}{l}\text { 3. Vízióalkotás } \\
\text { (Mit szeretnénk elérni?) }\end{array}$ & $\begin{array}{l}\text { Kihívások: } \\
\text { Milyen célokat tüz ki a vezetés? }\end{array}$ & - \\
\hline $\begin{array}{l}\text { 4. Taktikaalkotás } \\
\text { (Hogyan szeretnénk a célokat } \\
\text { elérni?) }\end{array}$ & $\begin{array}{l}\text { Politikai tudás: } \\
\text { Milyen politikai tudást igényel a } \\
\text { célok elérése és a megfelelö } \\
\text { eszközök kiválasztása? }\end{array}$ & $\begin{array}{l}\text { Interakciók iránya: } \\
\text { Milyen pályát írnak le a vezetők és } \\
\text { a követők közötti interakciók? } \\
\text { Hatalmi kapcsolat: } \\
\text { Miképpen értelmezhető a vezetők } \\
\text { és a követők hatalmi viszonya? } \\
\text { Vezető és követők szerepe: } \\
\text { Milyen szerepet kapnak a vezetők } \\
\text { és a követők a vezetés } \\
\text { folyamatában? }\end{array}$ \\
\hline $\begin{array}{l}\text { 5. Követők mobilizálása } \\
\text { (Miért kívánják a követők } \\
\text { mindezt elfogadni?) }\end{array}$ & $\begin{array}{r}\text { Vissza } \\
\text { a vezetés kö }\end{array}$ & $\begin{array}{l}\text { satolás: } \\
\text { tői értékelése }\end{array}$ \\
\hline
\end{tabular}

(2) Helyzetdefiniálás. A vezetők történetükben leírják a vezetés körülményeit és a politikai szituációt és kontextust (Hol vagyunk?), amelyben világossá teszik azt is, hogy a vezetés pontosan milyen kihívás előtt áll jelenleg. A helyzetdefiniálás fontossága abban rejlik, hogy az indoklásként alapozza meg a vezető későbbi politikáját: a „morális alapítást” (transzformatív vezetés), a „politikacsinálást” (tranzaktív vezetés) vagy a „bizonytalanság leküzdését” (karizmatikus vezetés).

(3) Vizióalkotás. A vezetők nem tehetik meg, hogy ne alakítsanak ki, vagy ajánljanak egy képet a közügyek kívánt állapotáról. Célokat tűznek ki, amellyel keretezik és konkretizálják a vezetés előtt álló kihívásokat. Ezzel olyan állapotot határoznak meg, amely nincs jelen az adott helyen és időben, de mégis vezetésük által elérhetővé válhat. A vezetők összekötik a kihívásként megjelenő állapotot a kollektív célokkal és lehetőségekkel, a múltat a jelennel, s a jelent a jövővel. Minden vezetéstípusnál megjelenik - különböző hangsúllyal és tartalommal - a vízióalkotás gondolata a morális iránymutatás (transzformatív vezetés), a közérdekkialakítás (tranzaktív vezetés) vagy egy új rend (karizmatikus vezetés) képében. Mindazonáltal megjelennek olyan további célok is, mint a konstruktív problémamegoldás, a követők felhatalmazása (transzformatív vezetés), a szükséges részvétel biztosítása (tranzaktív vezetés) vagy az alkalmasság bizonyítása 
(karizmatikus vezetés), amelyek a vízióban is megfogalmazásra kerülnek, de később a taktikaalkotás során realizálódhatnak.

(4) Taktikaalkotás. A taktikával a vezetők a vezetésük kimenetelét kívánják meghatározni. A taktikaalkotás során a vezetők implicit módon felvillantják azt, hogy mely politikai tudásra - az episztémére (transzformatív vezetés), a tekhnére (tranzaktív vezetés) vagy a praxiszra (karizmatikus vezetés) - kell támaszkodniuk ahhoz, hogy céljaikat elérjék és a megfelelő eszközöket kiválasszák. Az eszközválasztás tehát nem csak a célok függvényében értelmezhetök, hanem az a preferált politikai tudásról árulkodik, pontosabban arról, hogy a vezető miként kívánja a politikát befolyásolni és azt a kihívások szerint alakítani. A taktikaalkotás során a vezetésnek össze kell hangolnia a vezetők akaratát és a követők cselekvését, a közöttük lévő hézagot minimalizálva. A kapcsolat rendezéséhez a vezetésnek tehát arra is egyfajta választ kell nyújtania, hogy: Miképpen értelmezhető a vezetők és a követők hatalmi viszonya? (power with/over/to),,Milyen pályát írnak le a vezetők és a követők közötti interakciók? (horizontális/vertikális) Milyen szerepet kapnak a vezetők a vezetés folyamatában? (koaktiv/proaktiv/reaktív)

(5) Követők mobilizálása. A mobilizálás során megvalósul a visszacsatolás, azaz a követők értékelik és véleményezik a vezetők által nyújtott vezetést. A vezetőknek meggyőző kommunikációval meg kell indokolniuk követőik számára, hogy miért fogadják el az általuk felkínált identitást, helyzetleírást, víziót és taktikát. A vezetők erőfeszítése a hatásgyakorlásra fordított energiájukban fogható meg, amelyek vagy visszatükröződnek az állampolgárok preferenciáiban, vagy nem. Ezzel a követők ítéletet mondanak a vezető hitelességéről (a vezető azt teszi, amit mond), az általa megtestesített vezetésről és történetének további elemeiről.

Ezen elemzési síkok mentén fogom az empirikus elemzést folytatni és elhelyezni a vezetőket a heurisztikai eszközként szolgáló tipológiában. Itt tisztán kell látni, hogy egy-egy vezető tevékenységét nem lehet konstans módon kategorizálni. Ugyanis a vezetést a vezető ambíciói, lehetőségei és a konkrét politikai helyzet változása is befolyásolja. A vezetés tehát erősen kontextus függő, ezért annak elhelyezésére, $\mathrm{s}$ mozgásának behatárolására csak jól körülhatárolt szituációkban lehet kísérletet tenni. A vezetés értelmezését az is segíti, ha egymáshoz viszonyítva, párhuzamosan kerülnek elemzésre a vezetők. Ennek megfelelően eljárva a következő két fejezetben egy-egy problematikusnak tűnő politikai helyzetben hasonlítok össze két-két vezetőt. Amíg a 2015-16-os migránsválság kapcsán Orbán Viktor és Angela Merkel vezetését ( 8 . fejezet), addig a 2016-os Brexit népszavazás és a 2017-es brit parlamenti választások 
közötti időszakban Theresa May és Jeremy Corbyn vezetését elemzem (9. fejezet) a felvázolt elemzési szempontrendszerben egymáshoz, és az elméleti vezetéskonstrukciókhoz viszonyítva.

Az empirikus kutatás során összekapcsolom a vezetés retorikai és performatív tevékenységét. Ez a gyakorlatban annyit tesz, hogy egyszerre elemzem a releváns megnyilatkozásokat, azaz a retorikát, valamint a konkrét politikai döntéseket, és mindezeknek a követőkre gyakorolt hatását, azaz az előadást és annak értékelését. Ez abból a szempontból tünik fontosnak, hogy a különböző résztevékenységek eltérő mértékben kapcsolódnak a vezetés jelentésalkotásához. Amíg az identitásépítés, a helyzetdefiniálás és a vízióalkotás esetében erősebb a retorikai megnyilvánulás, addig a taktikaalkotás és a követők mobilizálása során a performatív cselekvés tủnik hangsúlyosabbnak. Az empirikus vizsgálódás három elemből tevődik össze, amelyek különbözőképpen járulnak hozzá a vezetői alkotótevékenységek feltárásához (4. táblázat).

- Kvalitativ tartalomelemzés. Azon megnyilatkozásokat vonom be a tartalomelemzésbe, s tekintem relevánsnak, amelyek közvetlenül kapcsolódnak az adott eseményekhez: a migránsválsághoz (Orbán, Merkel) és a Brexithez (May, Corbyn). A tartalomelemzésbe összesen 176 darab Merkel (2015.01.01. és 2016.09.18. között) és 103 darab Orbán (2015.01.01. és 2016.10.02. között), valamint 106 darab May és 44 darab Corbyn (2016.06.23. és 2017.06.08. között) ${ }^{49}$ megnyilatkozást vontam be, amelyek a MaxQDA tartalomelemző szoftverrel kerültek feldolgozásra. A kvalitatív tartalomelemzés során az ún. Boyatzis-féle tematikus kódolási protokollt követem (Boyatzis 1998; ld. erről: Klenke 2008, 94 95). Ennek előnye, hogy általa a manifeszt és a látens jelentéstartalmak is feltárhatóvá válnak az identitásépítés, a helyzetdefiniálás, a vízióalkotás és a taktikaalkotás témája mentén. Ezen túlmenően a követők mobilizálásának kapcsán rá kívánok mutatni a vezetői hatásgyakorlásra is. A vezetői hatásgyakorlás a

\footnotetext{
${ }^{49}$ Itt meg kell jegyezni, hogy a tartalomelemzés elsősorban azon vezetői megnyilatkozásokra vonatkozik, amelyek leírt változatát a vezetők közöltek a hivatalos weboldalaikon (www.bundeskanzlerin.de; www.bundesregierung.de; $\quad$ www.kormany.hu; $\quad \underline{w w .2010-2015 . m i n i s z t e r e l n o k . h u}$ www.gov.uk/government/speeches; www.jeremycorbyn.org.uk). Ezeket azonban szükségesnek tünt több forrásból kiegészíteni (pl.: www.ukpol.co.uk; www.magyaridok.hu). Például amíg Corbyn esetében 2017 márciusáig találtam megnyilatkozást saját oldalán, addig Maynél hiányoztak a politikai kampánybeszédek. Továbbá ezen megnyilatkozások stílusukban is igen különbözőek voltak. Orbán esetében teljesen hiányoztak a sajtótájékoztatók, de egy általa jegyzett publicisztikát (Magyar Idők) sikerült fellelni az időszakban. Ezzel szemben Merkelnél a beszédek, interjúk, sajtónyilatkozatok mellett sajtókonferenciákat is bevonhattam az elemzésbe. A brit vezetők esetében a beszédek és a sajtónyilatkozatok is elérhetőek voltak, de ezek mellett Maynél csak releváns sajtónyilatkozatokat, Corbyn esetében miniszterelnöki kérdéseket és válaszokat (Prime Minister's Questions) találtam.
} 
vezetők helyzetértelmezésre fordított energiájában érhető tetten, amelyet két indikátorban kívánok megfogni: (1) az adott eseményt tematizáló releváns szövegek az összes megnyilatkozáson belüli arányában; (2) a téma súlyában (részarányában) a releváns szövegeken belül. Ez utóbbi indikátor százalékos arányát a szöveg egészéhez viszonyított, a témát érintő szövegrész szavainak a száma adja.

- Történeti elemzés. A vezetők előadásának bemutatásához szükséges a szakpolitikai és politikai döntéseiket is kiemelni és összekapcsolni azokat a retorikai elemekkel. A döntések elemzése elsősorban a vezetői taktikaalkotás és a követők mobilizációja kapcsán válik relevánssá.

- Közvélemény-kutatások és választások elemzése. Az is megfigyelésre kerül, hogy a vezető jelentésalkotó tevékenységére miként reagál a szélesebb politikai közönség. A közvélemény-kutatások és választási, népszavazási eredmények tükrében bemutatom a vezetői előadásnak a követőkre gyakorolt hatását. A közvélemény-kutatások kapcsán elsősorban az egyes döntések elfogadottsági, politikus- vagy pártnépszerüségi mutatóira, vagy az intézmények bizalmi indexeire vagyok kíváncsi. Mindezek segítenek megragadni azt, hogy a vezetők mennyiben tudták mobilizálni és bevonni követőiket.

4. táblázat: Az empirikus elemzés fókuszai a jelentésalkotó tevékenységek fényében

\begin{tabular}{|l|c|c|c|}
\cline { 2 - 4 } \multicolumn{1}{c|}{} & Tartalomelemzés & $\begin{array}{c}\text { Történeti } \\
\text { elemzés }\end{array}$ & $\begin{array}{c}\text { Közvélemény-kutatások } \\
\text { és választások elemzése }\end{array}$ \\
\hline 1. Identitásépítés & $\mathrm{X}$ & - & - \\
\hline 2. Helyzetdefiniálás & $\mathrm{X}$ & - & - \\
\hline 3. Vízióalkotás & $\mathrm{X}$ & - & - \\
\hline 4. Taktikaalkotás & $\mathrm{X}$ & $\mathrm{X}$ & - \\
\hline $\begin{array}{l}\text { 5. Követők } \\
\text { mobilizálása }\end{array}$ & $\mathrm{X}$ & $\mathrm{X}$ & $\mathrm{X}$ \\
\hline
\end{tabular}

Célom ilyen módon az empirikus elemzéssel nem egy számszerűsíthető eredmény, vagy az elméleti vezetési konstrukciók igazolása, hanem a tipológia relevanciájának a bemutatása és a vezetői történetek újbóli, strukturált leírása. Ennélfogva az empirikus kutatás során két fő célkitüzést tartok szem előtt. Az elsö, hogy reményeim szerint a kifejtett elméleti vezetéskonstrukciók viszonylatában érthetőbbé válnak a politikusok retorikai és performatív teljesítményei a konkrét esetekben. A második, hogy ezek vizsgálata hozzásegíthet az empirikus elemzési keret továbbfinomításához, amelyre a disszertáció zárófejezetében kerül sor. Összességében a kutatás eredményei elképzeléseim szerint - az elméleti vezetéskonstrukciók és az empirikusan feltárt vezetői gyakorlatok feszültségében fog kikristályosodni. Az empirikus vizsgálat során 
narratív stratégiát követek, azaz egy konkrét problémát „mesélek” el, amelyet a leírt elemzési síkok szerint fogok strukturálni és az elméleti konstrukciók fényében értelmezni. Ezzel lényegében keretek között tartható lesz a vezetői történetek elmesélése. 


\section{8. \\ „MUTTER ANGELA" ÉS A „KONZERVATÍV \\ FELFORGATÓ" \\ Angela Merkel és Orbán Viktor vezetése a menekült- \\ /migrációs válság alatt}

$\mathrm{Az}$ európai politikát évekre meghatározó menekült- és/vagy migrációs válságot ${ }^{50}$ a politikai kommentátorok és elemzők a demokratikus vezetés próbájaként írták le. Ezzel előre vetítve a demokrácia morális értelmezésének a védelmének szükségességét és az ebből fakadó politikai válaszok érvényesítését. Így nem véletlen, hogy: amíg Angela Merkel, aki a válságot humanitárius krízisként értelmezte, morális vezetésével ikonná vált (,Mutter Angela”: Der Spiegel 2015; „Person of the Year Chancellor of the Free World": Vick és Shuster 2015; Gibbs 2015; Meiritz 2015), addig a biztonsági kérdéseket előtérbe helyező és populista politikát folytató Orbán Viktor vezetését széles körben megkérdőjelezték (,Illiberalism: Playing with fear”: The Economist 2015; „The Conservative Subversive": Waller 2015).

A kutatás természetesen nem ezeket a percepciókat kívánja igazolni, csupán arra mutat rá, hogy a vezetők az adott kontextusban eltérő demokratikus vezetést kívántak érvényesíteni. Előzetesen leszürhető, hogy a két vezető a demokratikus vezetés két különböző típusát és gyakorlatát testesítette meg: amíg Merkelhez inkább a transzformatív vezetés, addig Orbánhoz a karizmatikus vezetés állt közelebb. De mit is jelent mindez? Miben is áll vezetésük különbsége? Miképpen épültek fel a vezetők történetei? Milyen kihívások elé állították magukat a vezetők? Milyen célokat tüztek ki? Milyen politikai tudást igényelt e célok elérése és a megfelelö eszközök kiválasztása? Miképpen értelmezhető a vezetők és a követők hatalmi viszonya? Milyen pályát írnak le a vezetők és a követők közötti interakciók? Milyen szerepet kapnak a vezetők és a

\footnotetext{
${ }^{50}$ Ahogy azt többen is megjegyezték (Holmes és Castañeda 2016; Janky 2017; Messing és Bernáth 2015, p. 9, 2017, p. 33 1. lábj.) már a válság megnevezése is problémás, hiszen az nagymértékben meghatározza a diskurzus irányát, a politika tárgyát és szereplöit. Ezért a tanulmányban a vezetőktől függően felváltva használom a megnevezéseket: amíg Orbán Viktor valóságértelmezésének feltárása során az általa preferált „migrációs -/ migránsválság” és a „migráns” kifejezésekre támaszkodom, amelyhez elsősorban negatív konnotáció kapcsolódik, addig Angela Merkel esetében a „menekültválság” és a „menekült” kifejezéseket használom. Merkel válságértelmezése a „menekült” és a „menedékkérö” jogi kategóriáin alapult (lásd: a menekültek helyzetéről szóló 1951. évi egyezményt és az 1967. évi jegyzőkönyvet), amelyek a befogadás jogi és morális kötelezettségét vetítették elöre. Fontos leszögezni, hogy a szerző szóhasználatának nem célja a keretezés vagy épp az értékítélet, de elengedhetetlennek tủnik a vezetők alkotó tevékenységének feltárásához a kifejezések megfelelö és pontos használata.
} 
követők a vezetés folyamatában? Az elkövetkező összehasonlító esettanulmányban ezekre a kérdésekre keresem a válaszokat.

\subsection{Az eset kontextusa: a válság és a vezetők háttere}

A 2015-16-os években a menekült- és migrációs válság meghatározta Európa politikai napirendjét, amelyet az állampolgárok többsége az Európai Unió (EU) egyik legnagyobb kihívásaként jelölt meg ebben az időszakban (European Commission 2015b, 2016d, 2016c). A válság két évében a becslések szerint 2,3 millió fő lépett be illegálisan az Európai Unió területére és megközelítőleg 2,5 millió menekültkérelmet nyújtottak be (European Parliament 2017).

Németországra és Magyarországra különbözőképp nehezedett a válság súlya. Tranzitországként Magyarországra a Frontex (2015) számítása szerint ebben az időszakban 482.270 fö, a rendőrség által elfogott személyek számát tekintve 411.537 fö $^{51}$ érkezett illegálisan, amely tízszerese a 2014-es, és húszszorosa a 2013-as adatoknak. Az Eurostat (European Commission 2016a) kutatása szerint 2015-ben háromszor annyi menedékjogi kérelem érkezett be, mint az azt megelőző évben. Az ország lakosságához mérve a menedékkérők száma kimagaslik más tagállamokhoz viszonyítva (A. Juhász és Molnár 2016, p. 266). Ennélfogva az ország válságnak való kitettsége még tranzitországként is jelentős volt a válság első évében. Viszont 2016-ra mind az illegális határátlépők, mind a menedékkérők száma (European Commission 2017; A. Juhász és Molnár 2016, pp. 264-69) is jelentősen csökkent. Ellenben célországként Németországban a trend nem változott: 2014-ben 202.834 fö, 2015-ben 476.649 fö, míg 2016-ben 745.545 fö nyújtott be menedékkérelmet (BAMF 2016a) ${ }^{52}$.

A válságot ugyanakkor nem lehet kizárólag számadatokkal megfogni. A válságot két ellentétes értelmezés is áthatotta, amelyek mentén a politikai szereplők meghatározhatták saját „valóságukat” és cselekvésüket.

Az első értelmezés a kialakult helyzet „emberi arcát” emeli ki, és az események sorozatát humanitárius válságként értelmezi. A válság súlyát itt olyan történések jelezték, amelyek az emberi szenvedést, áldozatokat és személyes tragédiákat jelenítették meg. Ezen értelmezés morális kötelességként tekint a menekültek befogadására és védelmére, amely végül egész Európa felelősségévé vált (Radu 2016) ${ }^{53}$.

\footnotetext{
${ }^{51}$ Saját számítás a police.hu adatai alapján.

${ }^{52}$ Ennél az Eurostat (European Commission 2016a, 2017) becslése némiképp alacsonyabb.

${ }^{53}$ Jean-Claude Juncker (2015) szavai is erre mutattak rá: „Mindenekelőtt emberiességről és az emberi méltóságról van szó. (...) Amiben Európa egyértelmüen alulteljesített, az a területünket már elérő 
Így váltak kritikussá olyan válságtünetek, amelyek rámutattak az EU menekültpolitikájának gyengeségeire, a tagállamok leterheltségére (Bagdonas 2015; Popescu 2016; Trauner 2016) és végsősoron az európai együttmüködés határaira (Bagdonas 2015). Mindez - a korábbi 2003-as biztonságpolitikai, a 2005-ös alkotmányos és a 2010-2012-es pénzügyi válsághoz hasonlóan - a morális pánik (S. Cohen 2011; Flinders és Wood 2015; Kitzinger 2000) egy bizonyos formáját, az ún. „integrációs pánikot” (Cross and Ma 2015) idézte elő. Cross és Ma (2015) az általuk megfogott jelenség alatt egy krízis-szituációra adott olyan túlzott reakciót értenek, amely a „közös európai projekt” végét és dezintegráció veszélyét vizionálja. ${ }^{54} \mathrm{~A}$ tétet csak növelte, hogy a válság kapcsán kialakult konfliktusok közvetlenül érintették a liberális, a demokratikus és az emberi jogi alapértékeket, amelyekre a közös európai projektet, és így magát a menekültpolitikát is építették (Boswell 2000). S így megkérdőjeleződött az EU „normatív hatalma” (Pace 2007) is, amely magában foglalja olyan alapelvek és értékek védelmét és artikulációját, mint a joguralom, a jó kormányzás, a liberális demokrácia és az emberi jogok.

A második értelmezést a migrációhoz kapcsolt büncselekmények és terrortámadások sorozata jelentette. Ezek az események a migrációban rejlő veszélyekre rámutatva a „biztonságiasítás” (securization: Balzacq, Léonard, és Ruzicka 2016; Huysmans 2000) narratíváját hívták elő. Az így előtérbe került biztonságpolitikai kérdésekhez szorosan kapcsolódott egy gazdasági (jóléti sovinizmus) és kulturális (nemzeti identitás megőrzése) aspektus is. Ebben az értelmezésben felértékelődik a tagállamok szerepe a válságkezelésében a ,közös európai megoldás” rovására. Itt is megjelent egyfajta morális pánik (S. Cohen 2011; Flinders és Wood 2015; Kitzinger 2000; Messing és Bernáth 2015), de itt nem a közös európai projekt végét, vagy épp a morális felelősség elmulasztását vizionálták, hanem a közösségre jellemző értékek, identitás, életvitel elvesztését és a biztonság érzetének megrendülését vélték felfedezni. Összességében a

menekültek tekintetében mutatott közös szolidaritás. (...) Menedékpolitikánkat európaibbá kell tennünk. Több Unióra van szükség a menekültügyi politikánkban.”

54 A tagállamok közötti nézetkülönbségek, a migrációellenes vélemények megerősödése az európai vezetés értelmezésében „,egzisztenciális válságot” eredményezett: „Európai Uniónk - legalábbis bizonyos tekintetben - egzisztenciális válságban van. (...) olyat még soha nem láttam, hogy ennyire kevés egyetértés legyen a tagállamok között. Hogy ilyen szűk területen legyenek hajlandók együttműködni egymással. Soha még ennyi vezetőt nem hallottam csak a belföldi problémáikról beszélni úgy, hogy Európát még csak meg sem említik, vagy ha igen, csak mintegy mellékesen. Soha nem láttam még, hogy az uniós intézmények képviselői ennyire eltérő prioritásokat határozzanak meg, amelyek akár szöges ellentétben is állhatnak a nemzeti kormányokkal és a nemzeti parlamentekkel. Mintha az EU és a tagállami fővárosok teljesen külön utakon járnának. Soha nem láttam még, hogy a nemzeti kormányokat ennyire gyengítették volna a populista erők, és ennyire megbénította volna a soron következő választásokon elszenvedhető vereség kilátása.” (Juncker 2016) 
két ellentétes értelmezés nemcsak különböző következtetésekre vezettek, de egymás válságképét is erősítették.

A helyzetben rejlö politikai és morális bizonytalanság kihangsúlyozta a demokratikus vezetés kérdését, amely Angela Merkel és Orbán Viktor megítélésében is meglátszott. Merkel válságkezelésével és humanitárius szempontokat előtérbe helyező válságértelmezésével morális (transzformatív) vezetőként lépett fel és ekként is ünnepelték (Der Spiegel 2015; Gibbs 2015; Meiritz 2015; Vick és Shuster 2015). A 2005-ben - első kelet-német és női kancellárnak megválasztott Merkel elsősorban pragmatizmusáról és attentizmusáról volt ismert (Helms 2012d, pp. 119-123.; Helms és Van Esch

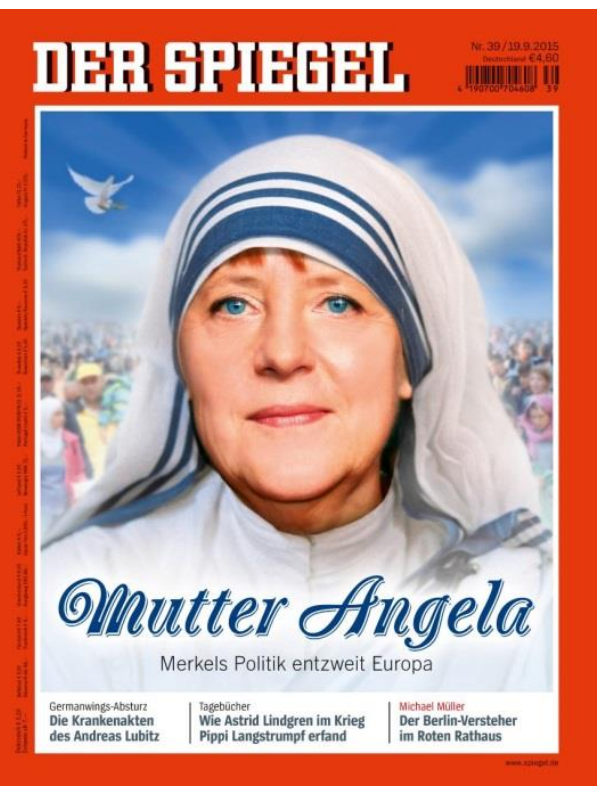

3. ábra: Merkel, mint Teréz anya (forrás: Der Spiegel 2015) 2017; Helms, Van Esch, és Crawford 2018; Middelhoff, Schijvenaars, és De Landtsheer 2016). Legvégsőkig ragaszkodott a „kis lépések politikájához” (,die Politik der kleinen Schritte": Gibbs 2015; Middelhoff, Schijvenaars, és De Landtsheer 2016), amellyel kerülte a kockázatos, nehéz és megosztó döntéseket és kivárta a kínálkozó lehetőségeket. Nem rendelkezett nagy vízióval, erős ideológiai elköteleződéssel, ellenben különösen nagy figyelmet szánt a részletekre. Politikája meglepően sikeresnek bizonyult német és európai kontextusban, a koalíciós kormányzás és a sorozatos EU-t érintő külpolitikai és gazdasági válságok során. A menekültválság alatt azonban Merkel erős morális meggyőződéséről tett tanúbizonyságot azzal, hogy kiállt a „befogadás kultúrája” (Willkommenskultur) és a „nyitott ajtók politikája” mellett (Helms, Van Esch, és Crawford 2018; Mushaben 2017a; Stefani 2017). Az irányváltás természetesen nem volt előzmények nélküli, ugyanis a migrációs és integrációs politikában már 2005-ben megkezdte a kancellár a paradigmaváltást, amellyel már a válság előtt végeredményben kialakított egyfajta Willkommenskultur-t (Mushaben 2017b; Trauner és Turton 2017). Összességében Merkel a válság során a politikáját meghatározó tranzaktív vezetés irányából a transzformatív felé mozdult el.

Ezzel szemben Orbán Viktor populista és idegenellenes válságnarratívájának és intézkedéseinek morális alapját széles körben megkérdőjelezték (The Economist 2015; Waller 2015). Orbán vezetése alapjaiban különbözik a német kancellárétól. A magyar 


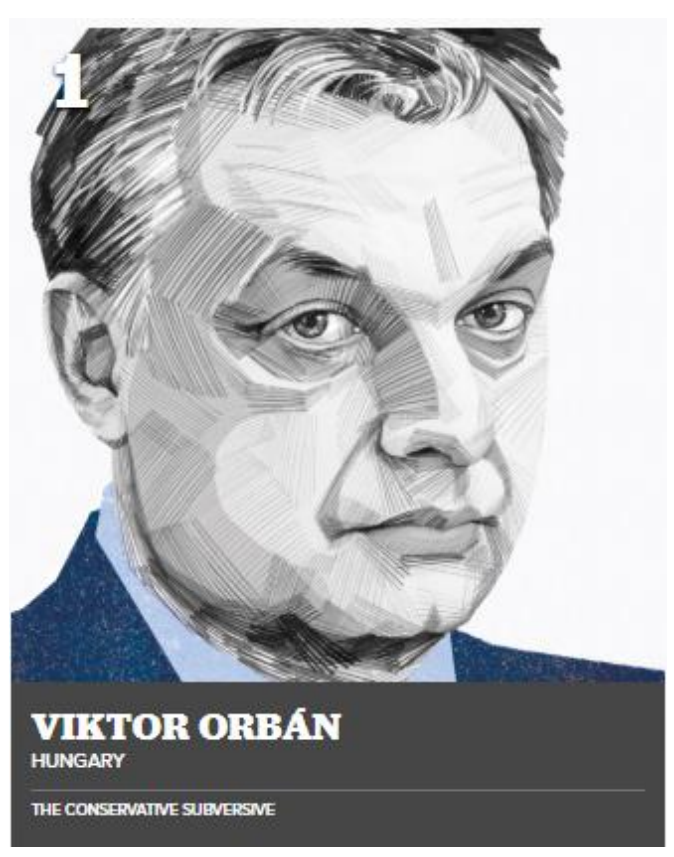

4. ábra: Orbán Viktor, mint konzervatív felforgató (forrás: Waller 2015) pártvezető és kormányfő mindig is tudatosan kereste a konfliktusokat, vállalta a kockázatot annak érdekében, hogy a legteljesebben uralhassa saját politikai környezetét. Elöször pártja irányítását vette át és vezette azt át egy politikai pólus- és ideológiai váltáson, majd meghódította a politikai jobboldalt (Csizmadia 2006b, pp. 11-18; Enyedi 2005), míg végül 2010 után egy új politikai rezsimet épített személye és politikája köré (Illés, Körösényi, és Metz 2018; Körösényi 2017; Körösényi és Patkós 2017). Orbán politikai vállalkozóként ráérzett a populista politika elönyeire az ideológiai és értékalapú megközelítéssel

szemben. Ennek megfelelően általánossá és konstanssá vált a válságnarratíva, az ellenségkeresés és -kreálás, az érzelmek és a követők mobilizálása és az identitásépítés. Karizmatikus vezetésének tökéletes lehetőséget jelentett a migrációs válság (Kiss 2016; Metz 2017), amelyet a biztonságiasítás narratívájába ágyazva kezelt (Szalai és Gőbl 2016). Mivel szakpolitikai és politikai értelemben előzmények nélkülinek volt tekinthető a probléma, az új helyzet nyílt terepet jelentett a vezetői válságértelmezésnek és a demokratikus valóság kialakításának.

\subsection{Az identitásépítés}

A válságszituációban rejlő bizonytalanság nyomán megnőtt az identitásépítés igénye, amelyre mindkét vezető reflektálni kívánt. Meghatározták a politikai közösségük tartalmát és határait, Európában betöltött helyét és az azon kívüliek csoportját: a menekülteket/migránsokat, a terroristákat, szélsőjobboldali szélsőségeket vagy épp a válság felelőseit. Mindebből leszürhető, hogy kik tartoznak a követők csoportjába és mit is gondolnak a vezetők róluk. Merkel számára a morális alapra helyezett nemzeti közösségen túl a menekültek és EU tagállamok is a követők csoportját gyarapították, akiktöl egyaránt kölcsönösen aktív (koaktív) részvételt várt el a válság kezelésében. Ezzel szemben Orbán a követők közösségét leszükíti a keresztény Magyarországra, Közép-Európára és Európára, élesen leválasztva a bevándorlókat és a politikai felelősöket. Itt, amíg a csoporton kívüliek aktív előidézői a válságnak, addig a követők olyan reaktív és passzív szereplők, akiket meg kell védeni a válság hatásaitól. 
Angela Merkel elsősorban saját közösségének leírására fókuszált, amelyet morális alapokra helyezett. Értelmezésében a német és az európai identitás a tolerancia, az igazságosság, a szabadság, a nyitottság és az együttérzés univerzális értékeiből fakad, amelyekhez minden körülmények között ragaszkodni kell. Ez a morális közösség egyszerre ró kötelezettséget mindenki számára (A. Merkel 2015q) és ad okot a nemzeti büszkeségre $^{55}$ (A. Merkel 2015s). Ebből a szempontból vált állandó hivatkozássá Merkel történetében a német Alaptörvény ${ }^{56}$ és a belőle fakadó humanizmus (,die Humanität unsres Grundgesetzes": A. Merkel 2015s) is. Merkel részben újraértelmezte a német alkotmány politikai menekültekre vonatkozó „16a” cikkelyét, amellyel lényegében kitágította a menekültek helyzetéről szóló 1951. évi menekültügyi egyezmény menekült kategóriáját. Ezáltal a menekült státuszhoz már nem volt szükséges a közvetlen veszély az üldöztetésre. Söt erre hivatkozva Merkel végig visszautasította, hogy az ország meghúzza a befogadandó menekültek számának felső határát $^{57}$ (Helms, Van Esch, és Crawford 2018, p. 10). Összességében az Alaptörvény univerzális értékei lehetővé teszik, hogy Németország helyesen járjon el a menekültválság során és „,befogadó kultúrává” (A. Merkel 2015b, 2015o), „nyitott társadalommá” („offenen Gesellschaft”: A. Merkel 2015o), „bevándorló országgá” (,Einwanderungsland”: A. Merkel 2015s) váljon:

„Mindezek ellenére az országunk még mindig egy jó ország. Jó állapotban van. A sokat dicsért civil társadalom jelenti a valóságot számunkra. Büszkévé és hálássá tesz engem, ha azt látom, hogy szerte Németországban miként reagál számtalan ember a menekültek érkezésére. Azok száma, akik ma tesznek a menekültekért, és azon segítők száma, akik idegeneket kísérnek át városokon és irodákon keresztül, vagy épp fogadnak be otthonukba, sokszorosan meghaladja a gyülölködők és idegengyülölők számát" (ford. tőlem) (A. Merkel 2015s)

Németország morális felelősségvállalását testesítette meg azon cselekvő alanyként megjelenő civilek és polgárok, akik önkéntesként segítették a menekültek fogadását, ellátását és integrációját. Ők váltak a történet igazi „hőseivé” (,Diese Bürgerinnen und

\footnotetext{
55 „Büszkék lehetünk a közös európai értékeinkre, a szabadságra, a demokráciára és a jogállamiságra. S büszkék lehetünk egyedülálló társadalommodellünkre, amelyet a világon sokan irigyelnek és amelyet egy globális versenyben kell megőriznünk." (ford. tőlem) (A. Merkel 2016d)

56 „Néhány világos alapelvre van szükségünk ahhoz, hogy megfelelőképp bánhassunk az emberekkel, akik jelenleg is érkeznek hozzánk. Ezek az alapelvek nem többek és nem kevesebbek, mint amik az Alaptörvényünkböl, alkotmányunkból következnek." (ford. tölem) (A. Merkel 2015s)

57 „A politikai menekültek alapvető menedékjogának nincs felső határa.” (ford. tőlem) (A. Merkel 2015t)
} 
Bürger, sie sind die stillen Helden unseres Lebens.": A. Merkel 2015q) és koaktív szereplőivé. Ezt támogatva Merkelnél (2015e, 2015b) szimbólumként jelentek meg a müncheni állomás képei is, amelyben a németek barátságosan fogadják a menekülteket. Viszont amíg a közösség morális értelemben kinyílt mindenki - pontosabban a rászorulók és az aktív állampolgárok - előtt, addig azon kívül rekedtek azok, akik a menekültellenes kritikáknak adtak hangot. A kancellár zéró toleranciát ${ }^{58}$ hirdetett a diszkriminációval, a gyülöletkeltéssel és az idegenellenességgel szemben, amely ellen a jogállamiság minden szigorával fel kíván lépni (A. Merkel 2015a, 2015o, 2015s). Merkel a közösség morális határainak lezárását komolyan vette: amennyiben a közösség nem tesz eleget a morális elvárásoknak, akkor lemond a „tagságáról”: „[n]agyon öszintén mondom: ha most még bocsánatot is kellene kérnünk azért, mert barátságos arcot mutatunk egy vészhelyzetben, akkor ez nem az én országom." (ford., kiemelés tőlem) (A. Merkel 2015e) Mindezzel a (ko)aktív követés morális kötelezettséggé vált.

Németország felelősségvállalásából egyenesen következett Európa morális vezetése is:

„[E]urópaiként olyan értékek mellett állunk ki, olyan értékeket hirdetünk a világban, mint a szabadság, a jogállamiság és a demokrácia, s mindezt azért is tesszük, mert hitelesnek kell lennünk.” (A. Merkel 2016a)

„Ha mi [Németország] bátorságot mutatunk és mutatjuk az utat, akkor a közös európai megoldás elérhetővé válik.” (ford. tőlem) (A. Merkel 2015o)

Ebből az is következik, hogy a merkeli vezetés szemszögéből a többi európai államára is vonatkozott a követés (morális) kötelezettsége. Ezért különösen kritikus fényben jelentek meg a merkeli történetben azon államok köre (például Nagy-Britannia, Dánia és a visegrádi országok), amelyek nem tesznek eleget morális kötelezettségüknek és így aláássák a európai szolidaritást (A. Merkel 20151, 2015s). Ezzel kapcsolatban érdekes, hogy Merkel diplomatikusan fogalmazott a vonakodó és ellentétes politikát folytató Orbánnal kapcsolatban, és elsősorban a külső határok védelmét illető konszenzust, a regisztráció kötelezettségének való megfelelést, valamint a Dublin rendelet érvényesítését emelte $\mathrm{ki}^{59}$

\footnotetext{
58 „Mindannyiunknak erőfeszítést kell tennünk, hogy világossá tegyük: nincs tolerancia azokkal szemben, akik megkérdőjelezik más emberek méltóságát, nincs tolerancia azokkal szemben, akik nem állnak készen, hogy segítsenek, ahol jogi és emberi segítségre van szükség.” (ford. tőlem) (A. Merkel 2015j)

59 „Találkoztam ma Orbán Viktorral mind az EPP ülésen, mind a Tanácsban. Vannak olyan pontok, amikben teljesen egyetértünk és vannak, amikben nem. Az egyetértés abban áll, hogy a külsőhatárokat meg kell védeni” (ford. tőlem) (A. Merkel 2015h).
} 
Érdekes módon Orbán Viktor kisebb teret adott saját közösségének a leírására. Homályos maradt az identitás annak ellenére, hogy a kvótareferendum kapcsán Orbán Viktor kiemelte az identitásépítés jelentőségét: „hogyha kellő távolságból nézzük ezt a kérdést, akkor igazából arra keressük a választ a népszavazással, hogy kik vagyunk mi, és kik akarunk lenni.” (Orbán 2016a) Gyakran használt fordulat volt megnyilatkozásaiban a „mi, magyarok”, a „mi, közép-európaiak” és a „mi, európaiak” megfogalmazás. Számára Magyarország a visegrádi országokkal együtt a régi, keresztény Európa egyik utolsó mentsvára.

„A keresztény Európa (...) közös, leírható identitás. (...) Az egzisztenciális fenyegetés azt jelenti, hogy mi, európaiak elfelejtettünk magunkért küzdeni. Azt kell azonban mondanunk, hogy ezek a mi értékeink, ez a mi történelmünk, ez a mi életünk úgy, ahogy élni akarjuk, és ezt meg fogjuk védeni. Nem ezt tesszük. Erről még elméletileg sem beszélünk. Amikor az Európai Tanácsban a keresztény Európáról beszélek, a többiek úgy néznek rám, mintha most jöttem volna a középkorból.” (Orbán 2015a)

Az orbáni történetben a követök közössége a közös nemzeti és kulturális identitáson alapult. A követők azáltal, hogy ki vannak szolgáltatva a válság hatásainak, passzív és reaktív szerepbe kényszerültek.

Ez azonban maga után vonja azt is, hogy a vezető a csoporton kívülieket aktív cselekvőként és „veszélyforrásként” tüntesse fel. Ezért a követők csoportján kívül eső bevándorlókat illetően Orbán Viktor már differenciáltabban fogalmazott. Noha élesen elválasztotta a gazdasági vagy megélhetési bevándorlókat és a valódi, politikai menekülteket és üldözötteket, mégis az összes illegális határátlépöt negatív színben tüntette fel. Expliciten egybemosta a migránsok növekvő számát a terrorizmus veszélyének növekedésével és a közbiztonság romlásával. ${ }^{60}$

„Nem gondoljuk azt, hogy mindenki, aki onnan jön, terrorista, de nem tudjuk, senki sem tudja megmondani, hogy hány terrorista érkezett a migránsok között eddig, hányan vannak már itt, és hányan érkeznek még nap, mint nap. Terroristából egy is sok.” (Orbán 2015i)

S bár Orbán több helyen megjegyzi, hogy fontosnak tartja az iszlám civilizáció megbecsülését a magyar muszlim közösséggel egyetemben, mégis veszélyesnek

60 „Aki a Közel-Keletről tömegével hoz az országba regisztrálatlan bevándorlókat, az (...) terrorizmust, bünözést, antiszemitizmust, homofóbiát importál." (Orbán 2016k) 
gondolja, ha hirtelen megugrana a számuk, és párhuzamos társadalmak jönnének létre Európában.

Ezzel szemben Merkel lényegesen kisebb figyelmet szán a menekültek csoportjának a leírására, akiktől viszont (ko)aktív részvételt és viszonyulást vár el a német alapértékek elfogadása az integráció és beilleszkedés kapcsán. Merkel a menekültek emberséges fogadására; és kulturális, társadalmi és gazdasági integrálására helyezte a hangsúlyt (A. Merkel 2015m), amellyel ki lehet küszöbölni azt, hogy párhuzamos társadalmak jöjjenek létre (A. Merkel 2015o). Aláhúzta, hogy a menekültek befogadásával és integrációjával járó változás ellenére „Németország Németország marad” (A. Merkel 2016e). Értelmezésében a változás nem lehet rossz, ugyanis az nem veszélyezteti az ország, a közösség alapértékeit: a liberalizmust, a demokráciát, a jogállamiságot és a szociális piacgazdaságot. Történetét alátámasztva a menekültek emberi arcát mutatta. Kiemelte a menekültek félelmeit, a háborút és a terrort, melyek arra késztették őket, hogy elhagyják hazájukat. Családok és gyermekek személyes történetével személyesítette meg a menekülteket (A. Merkel 2015d, 2015s). Mindazonáltal pragmatikusan a bevándorlók visszaküldése kapcsán meg is különböztette azokat, akik nem szorulnak védelemre, vagy csak gazdasági okok miatt keltek útra.

A megfogalmazásokból jól kivehető, hogy a Merkel által preferált menekültekkel szemben Orbán szemszögéből a bevándorlók, migránsok nem „érdemlik meg” a pozitív elbánást és a befogadást. A menekült (Flüchtling) és a bevándorló, migráns (Einwanderer, Zuwanderer, Migrant) fogalmak közötti megkülönböztetés áthatotta és vezette mind a német, mind a magyar politikai diskurzust és közbeszédet. Amíg a német kontextusban a politikai közösség leendö tagjaként a menekült, addig a magyarban a közönségen jogi és politikai értelemben is kívül eső migráns megnevezés és a hozzájuk kapcsolódó társítások domináltak (Holmes és Castañeda 2016; Janky 2017; Messing és Bernáth 2015, 2017; Vollmer és Karakayali 2018).

A migránsok meghatározásán túl Orbán célirányosan kereste és találta is meg a válság felelőseit. Orbán a kialakult válsághelyzetért egy általa abszurd és bizarr koalíciót vádolt:

„Létrejött egy bizarr nagykoalíció: az embercsempészek, az emberjogi aktivisták és a brüsszeli bürokraták koalíciója. Ez a koalíció (...) azért dolgozik, hogy biztonságosan, gyorsan és jogszerüen ideszállíthassa és betelepíthesse közénk a migránsokat.” (Orbán 2015c) 
A miniszterelnök egy háttérhatalmat vélt felfedezni mögöttük, amelyet expliciten Soros György $^{61}$ nevéhez kötött, aki a kormány „ellenzékeként”, az általa támogatott civil aktivisták útján avatkozik be Magyarország belügyeibe és az EU politikájába. Ebben a keretben a civil szervezetek és a baloldali és liberális, európai politikai elit együttesen kívánják - proaktív módon - kihasználni a válsághelyzetet, hogy Európa nemzeteit, a keresztény értékeket gyengítsék és saját szavazóbázisukat a migránsokkal növeljék.

Ezzel párhuzamosan a kormányfó az EU vezető politikusait inkompetens, cselekvésképtelen bürokratákként állítja be, akik nem életszerü szabályozással kívánják kezelni a válságot. A problémát azonban nem az EU-ban, hanem annak ideológiai eltorzulásában látta. Ezzel - értelmezésében - az Unió túllép saját eszméin, amely annak a veszélyét vetíti elöre, hogy a Szovjetunióhoz hasonlóvá válik. Ezt az ideológiai irányt és a „meddő” válságkezelést „brüsszelizmusnak” nevezi:

„[n]ézze, itt van egy dolog, amit én brüsszelizmusnak nevezek. Előáll egy gond, egy kihívás. Anélkül, hogy megvizsgálnánk, hogy melyik szinten tudnánk a legjobb választ adni rá, első reflexből kimondjuk: európai megoldás szükséges. (...) [O]lyan szavakat mondunk, hogy „,közös európai megoldás," miközben nem történik érdemi dolog. Ennek az az eredménye, hogy miközben Brüsszel magához akar vonni újabb és újabb hatásköröket, amiket nem tud ellátni, ezzel meggyengíti a nemzetállamokat, ezen keresztül meggyengíti egész Európát.” (kiemelés tőlem) (Orbán 2016c)

Annak ellenére, hogy Európa vezető politikusait - mint például Jean-Claude Junkert erős kritikával illette, Merkellel szemben, politikáját érintő kritikus megjegyzéseken túl, végig mérsékelt és visszafogott volt. ${ }^{62}$

\footnotetext{
61 „Én nem bonyolódnék ilyen összeesküvés-elméletekbe, csak a tényeket mondom. A magyarországi ellenzék ereje elmarad a Soros György által finanszírozott magyarországi szervezetek politikai befolyásától. Ez egy háttérhatalom, nem választotta meg öket senki, mégis folyamatosan politikai befolyásra törekednek, és befolyást is gyakorolnak egyébként a politikai döntéshozatalra egy demokrácia természetes szabályai szerint. $\mathrm{Na}$, de a pénz ezekhez a szervezetekhez, ezekhez a nyilvánosságfórumokhoz javarészben Soros György háttérhatalmi rendszerén keresztül érkezik." (Orbán 2016f)

62 „A német kancellár mindig mindent jól csinál - ez a magyar alkotmány első paragrafusa” (Orbán 2015f) „A német kancellár karakteres és erős vezető, ez kétségtelen. Mindenkinek, így nekünk, magyaroknak is jó okunk van arra, hogy tiszteljük és bízzunk benne. Az ő esetében nem a személyes tulajdonságok hiányoznak, hanem a mozgástér. Néha Gulliver jut róla eszembe, akit a liliputiak ezernyi apró kötéllel és karóval kötöztek a földhöz. (...) [U]gyanis a legutóbbi német választások óta nagykoalícióban kénytelen kormányozni.” (Orbán 2015g) Itt lép életbe a magyar alkotmány második cikkelye: soha ne adj tanácsokat a német kancellár asszonynak. (...) Nem, a kancellár asszony sohasem árult el bennünket, akkor sem, ha vannak nézetkülönbségeink, például a migránsok európai elosztása tekintetében.” (Orbán 2016k)
} 


\subsection{A helyzetdefiniálás}

A válság definiálásával a vezetők kontextusba helyezik saját történetüket és meghatározzák a kihívásként értelmezett állapotot. Már a válság megnevezésével megállapítják, hogy a válság mely értelmezéséhez kívánnak csatlakozni. Erre Orbán is rátapint: „[m]ár ott kezdődik, hogy milyen nevet adunk a jelenségnek. A németek menekültválságnak nevezik, mi migrációs válságnak” (Orbán 2015a) Amíg Orbán Viktor válságértelmezése a biztonságiasítás narratíváját követte (Szalai és Gőbl 2016), addig Merkel elsősorban humanitárius válságként írta le az eseményeket és az elmaradó európai szolidaritást hangsúlyozta (Helms, Van Esch, és Crawford 2018; Mushaben 2017b, 2017a). Ugyanakkor azt is fontos aláhúzni, hogy tranzitországként Magyarországon a migráció problémája értelmezési vákuumba csöppent, amely így lehetőséget adott a válság szabad értelmezésére. Ezzel szemben Merkel számára a válságértelmezés szorosan kötődött a 2005-től kezdődő migrációs és integrációs politika paradigmaváltásához (Mushaben 2017b; Trauner és Turton 2017). Mindez azt jelenti, hogy Orbán a bizonytalanság leküzdésére (karizmatikus vezetés), míg Merkel egyfajta morális alapításra (transzformatív vezetés) vállalkozott, amely Willkommenskultur fogalomban volt tetten érhetö.

Merkel történetében egyaránt jelentek meg morális és pragmatikus elemek. A válságot ugyan több alkalommal is számszerüsítette (Németországban 800.000 és világszerte 60 millió menekült), de aláhúzta a számok mögött meghúzódó személyes sorsokat és emberi tragédiákat (A. Merkel 2015o) is. Nagy hangsúlyt helyezett arra, hogy bemutassa a humanitárius válság okait (háborúk, etnikai és vallási konfliktusok és katasztrófák) és következményeit (kilátástalanság, halálos veszély és tragédiák az Európába vezető úton). Az oksági kapcsolat kihangsúlyozásával kívánta igazolni a rászoruló menekültek megjelenését és előrevetíteni az erre adott emberséges válaszok szükségességét. Ehhez kapcsolódott az is, hogy Merkel a kialakult helyzet súlyának szemléltetésére gyakorta hívta elő a kollektív emlékezetből viszonyítási pontként a második világháborút, amellyel implicit módon rámutatott a német társadalom morális felelősségére a válság rendezésében. Mindehhez azonban azt is hozzáteszi, hogy a biztonságosnak ítélt országokból érkezőket nem áll módjukban befogadni és a gazdasági menekülteket vissza kell küldeniük.

Ebben az értelmezésben a bevándorlás önmagában nem feltétlenül eredményez válságot, hiszen az leszükül a humanitárius katasztrófára. Mindazonáltal jelen vannak olyan körülmények, melyek a válságkezelést ellehetetlenítve mélyítik a válságot. 
Merkel bár a menekültválságról leválasztja a terrorizmus kérdését (A. Merkel 2015p, 2015s), mégis a menekültekre és az integrációra gyakorolt negatív morális hatás révén össze is kapcsolja azokat. A kancellár elismeri, hogy a menekültek között terroristák is érkeztek Európába, mégsem a menekültek hozták magukkal a terrort ide, hiszen a veszély már korábban is jelen volt a kontinensen. Az emberek többsége épp az effajta erőszak elől menekült egy békés élet reményében. Merkel (2015h, 2015o, 2015p) számára a rettegés és a félelem nem írhatja felül a közös értékeket: a szabadságot, a toleranciát és a jogállamiságot. Mivel ezáltal a terrorizmus visszavetheti az integrációt (A. Merkel 2015s), komoly morális veszélyt hordoz magában:

„Ez egy támadás volt szabadságunk, értékeink, meggyőződésünk és mindaz ellen, ami fontos számunkra, amiért a korábbi generációk Európában megküzdöttek és megharcoltak: a demokráciáért, az emberi jogokért, az egyenjogúságért és egy nyitott, barátságos és toleráns civil társadalomért.” (ford. tőlem) (A. Merkel 2015p)

Merkel morális veszélyt látott a terrorizmus mellett további két tényezőben is. Egyfelől kockázatként jelent meg történetében a menekültellenes szélsőjobboldali mobilizáció, amely ellentétes a válság morális olvasatával, s így a német és az európai közösség értékeivel (A. Merkel 2015k, 2015o). Ennek megfelelően - ahogy arra korábban már rámutattam - ki is zárta e politikát és képviselőit a morális közösségből. Másfelől rámutatott, hogy a tagállamok közötti szolidaritás hiánya tovább is mélyítheti a válságot, ugyanis az a közösség morális értékeit, identitását veszélyezteti:
„A menekültválságban nem engedhetünk a kísértésnek, hogy visszalépjünk a nemzeti kormányzati intézkedésekhez. Éppen ellenkezőleg, amire szükségünk van most, az több Európa. Nagyobb szükségünk van bátorságra és kohézióra, mint valaha (...) Nem old meg semmilyen problémát, sőt újabbakat kreálna, ha feladnánk értékeinket, $\mathrm{s}$ így elveszítenénk identitásunkat.” (ford. tőlem) (A. Merkel 2015m)

Merkel ezzel csatlakozott az integrációs pánik narratívájához és ily módon elítéli azon tagállamokat (Nagy-Britannia, Dánia, visegrádi országok), amelyek a szolidáris közös politikával szemben foglalnak állást és nem követik Németország és az EU morális vezetését. Mindazonáltal számol azzal a lehetőséggel is, hogy a válság közelebb hozhatja a tagállamokat, és mélyítheti az európai integrációt. 
Fontos aláhúzni, hogy a válság számokban mért nagysága nem jelenti azt, hogy a helyzet megoldhatatlan lenne Merkel számára. Ügyesen teremtett egyensúlyt: egyszerre mutat rá a helyzetben rejlő nehézségekre és arra, hogy az szolidaritással, együttmüködéssel és helyes politikai válaszokkal megoldható. A kancellár üzenetei végig optimisták maradtak. Narratívájában a helyzet pozitív irányba változik a válságkezelés nyomán: a menekültügyi folyamatok javultak, a döntések felgyorsultak, a menekültek helyzete rendeződött, a beérkező menekültek száma csökkent, túl azon, hogy a humanitárius kötelezettségüket is teljesítették (A. Merkel 2016b). Merkel egyértelmü volt: a folyamatokat a vezetés kézben tartja és így a (humanitárius) krízishelyzet rendeződik.

Orbán Viktor nemcsak gyökeresen eltérő definíciót adott a válságra, de történetében folyamatosan dramatizálta a helyzetet. Egy újkori népvándorlást írt le, amely során tömegek, népek kelnek útra, „szállják meg” és ,árasztják el” Európát. A migrációs nyomás itt konstans maradt, amely még akkor sem enyhült, amikor 2015 novembere után az ország közvetlen kitettsége jelentősen csökkent. Újabb és újabb migrációs hullámot vizionált a származási országok körét növelve. Narratívájában a tömeges bevándorlás veszélyezteti az európai életformát: a közbiztonságot, az életszínvonalat és a kultúrát. ${ }^{63} \mathrm{Az}$ egymást követő terrorcselekmények és más incidensek sora megteremtette azt a lehetőséget, hogy a terrorizmus, a bünözés növekedése és a migráció között összefüggést láttasson.

„Nem fogjuk hagyni, hogy [Brüsszel] ránk eröltesse kozmopolita bevándorláspolitikájának keserü gyümölcseit, nem fogunk bűnözést, terrorizmust, homofóbiát és zsinagógákat gyújtogató antiszemitizmust importálni Magyarországra, nem lesznek törvényen kívüli városnegyedek, nem lesznek zavargások, bevándorlózendülések, és nem fognak bandák vadászni asszonyainkra és lányainkra.” (Orbán 20161)

Az üzenet egyértelmü: a terrorizmus térnyerése a rossz európai menekültpolitikának köszönhető, ahogy azt a 2015. áprilisában elindított nemzeti konzultáció is sugallja. „Vannak, akik szerint a Brüsszel által rosszul kezelt bevándorlás összefüggésben van a terrorizmus térnyerésével." (kormany.hu 2015)

\footnotetext{
${ }^{63}$ Erre utal a nemzeti konzultációt kísérő plakátkampány három üzenete is: „Ha Magyarországra jössz, tiszteletben kell tartanod a törvényeinket!”, „Ha Magyarországra jössz, nem veheted el a magyarok munkáját!”, „Ha Magyarországra jössz, tiszteletben kell tartanod a kultúránkat!”.
} 
Orbán saját történetében többször kihangsúlyozta, hogy a liberalizmus, a multikulturalizmus $^{64}$ és a politikai korrektség gátolja a válságkezelést. Ez identitásválságot eredményezett és Európát is teljesen megbénította. S noha az EU müködését, az együttmüködést, a szabályok betartását illetően megrendült a bizalom, mégsem az EU konstrukciója jelenti a gondot Orbán számára, hanem a politikai vezetők.

„[A]z Európai Unió a megújulás vagy a szétesés keresztútja előtt áll: vagy megújítjuk az Európai Uniót, vagy az Európai Unió szét fog esni. Az álszent moralizálás, a kettős mérce, a liberális elit növekvő gőgje és a cselekvést megbénító ideológiai viták lejtöre terelhetik az uniót.” (Orbán 2016b)

Ebben az értelmezésben a liberális európai elit nemcsak, hogy képtelen kezelni a válságot saját ideológiai korlátai miatt, de saját választóitól és a népakarattól is eltávolodott. A liberális demokráciákban tehát szakadék van a nép véleménye és az elit által folytatott politika között, s így valójában a liberalizmus elszakad a szabadság és a demokrácia ideájától. A miniszterelnök értelmezésében a liberális gazdasági- és társadalomszervezési elvek csődöt mondtak a politika különböző területein, s így a menekültpolitikában is.

Összességében Orbán a válságban rejlő bizonytalanságot hangsúlyozza, amelyet az események dramatizálásával és érzelmi alapon történő értékelésével fokoz. Így vált a migrációs válság identitásválsággá, az identitásválság elitválsággá (Orbán 2015d), az elitválság demokráciaválsággá (Orbán 2015b, 2016m, 2016i). Ezzel szemben viszont Merkel számára a válság morális kérdés: humanitárius krízis, amelyre morális veszélyként hat a terrorizmus, a szélsőjobboldali mobilizáció és a tagállami együttmüködés hiánya. Ugyanakkor ő már ebben vélte felfedezni a közös identitás elvesztésének veszélyét.

\subsection{A vízióalkotás}

A vezető víziójában stratégiát alkot, hosszútávú célokat és követendő értékeket határoz meg, azaz irányt szab, és mutat közösségének. Amíg a helyzet definiálása során a vezető meghatározza az előtte álló kihívást, addig a vízióalkotás kapcsán már a kihívásként megjelenő célok kerülnek előtérbe.

\footnotetext{
${ }^{64}$ Itt megjegyezendő, hogy Merkel menekültpolitikájában szakított a multikulturalizmussal, ahogy azt a híressé vált 2010-es beszédében is leszögezi (Die Welt 2010).
} 
Merkel legfőbb kihívása a meghatározott morális alapelvek mentén értelmezett feladatának teljesítése (,Wir schaffen das”) volt. Ez magában foglalta: a humanitárius krízis rendezését, menekültek regisztrálását és integrálását, a nem jogosult bevándorlók számának csökkentését és az európai szolidaritás növelését. Bár történetében érezhetően háttérbe szorult a vízió a taktikaalkotással - a konkrét cselekvéssel és a döntésekkel szemben, mégis Merkel egy szük, pragmatista és feladat-orientált víziót vázolt fel. Ennek keretében megjelent a transzformatív vezetés morális alapitás gondolata, amely Németország Willkommenskultur-ként való értelmezését jelentette. Ez a morális alapítás a követők felhatalmazásában (empowerment), a morális iránymutatásában és némileg a tranzaktív vezetés irányába elmozduló konstruktív problémamegoldásban is megmutatkozott.

Mivel a követőkre (ko)aktív szerep hárul a válságrendezésében, kritikussá vált a követők beemelése a politikába. Egyfelől a német állampolgárok bevonása és aktív szerepvállalása kritikus a menekültek fogadása és integrálása szempontjából. Ez túlmutat az egyszerű politikai részvétel (preferenciák kinyilvánítás) biztosításán, hiszen az kiterjed a nem konvencionális részvételi formákra és személyes felelősségvállalásra, sőt egy transzformációra szólít fel:

„Rá kell a társadalmunkat ébreszteni a demokrácia ezen életelveire [Lebensprinzip]: a részvételre, a közös döntésre, a segítségnyújtásra és felelősségvállalásra. Alig lehet valami fontosabb az élethez való hozzáállásunk szempontjából, mint annak a tapasztalatnak a megbecsülése és érvényesítése, amellyel ebben a nagy civil társadalomban a szabadságot és a felelősséget tiszteletben tartjuk.” (ford. tőlem) (A. Merkel 2015q)

A követők beemelésének gondolata húzódik a menekültek integrálásának célja mögött is, akiket a politikai közösségbe kíván politikájával beemelni a politikai nevelés (kötelező munkaerőpiaci és állampolgári tanfolyamok) révén, és akiktől ebben az átalakító folyamatban ugyancsak kölcsönösen aktív együttmüködést követel meg.

Ezen, azaz az érdekelt felek bevonásán és mobilizálásán, $\mathrm{s}$ az együttes transzformáción alapult a merkeli menekült- és integrációs politika, konstruktív problémamegoldás. Ez azonban elsősorban nem deliberatív-részvételi politikán alapult, hanem a taktikaalkotásban megmutatkozó tranzaktív eszközökön (szelektív ösztönzőkön és szankciókon) és kompromisszumkészségen. S túl a morális érvelésen mindennek tétje a közérdekre való hivatkozásban mutatkozott meg. Merkel értelmezésében a menekültek integrációjuk révén gazdasági és társadalmi (demográfiai) előnyt és lehetőséget is 
jelentenek (,Die Zuwanderung von Menschen, die ein Gewinn für uns alle ist.”: A. Merkel 2015d, ld. például: A. Merkel 2015o, 2015i, 2015k). Másképpen fogalmazva, a bevándorlás lehetőséget rejt magában: ,[h]a jól csináljuk [az integrációt], akkor a helyzetben több lehetőség rejlik, mint kockázat." (ford. tőlem) (A. Merkel 2015o) Mindez azt a feltételezést vonja maga után, hogy a konstruktív problémamegoldás alárendelődik a tranzaktív vezetésre jellemző közérdek kialakitásának a céljának.

A morális iránymutatás vagy az ideológiai elköteleződés a merkeli politikára nem volt a válságot megelőzően jellemző (Helms, Van Esch, és Crawford 2018). Kerülte a kockázatos és megosztó döntéseket, s nem is mutatott fel a társadalmat átalakító nagy víziót. Merkel reaktív „kis lépések politikájához” párosult a feladat elvégzésére vonatkozó fegyelem és a részletkérdéseket illető figyelem is. Ezzel szemben a morális iránymutatás szimbolikus szinten kritikus elemévé vált a merkeli válságkezelésnek. Erős morális határokat szabott politikájának:

„Németország azt teszi, ami a morális és jogi kötelessége. Se többet, se kevesebbet.” (ford. tőlem) (A. Merkel 2015g)

„Amikor járunk a világban és felvilágosítjuk az embereket a demokráciát, a szolidaritást, az igazságosságot, az egyéni szabadságot és az emberi méltóságot illetően, akkor ezen értékeknek kell vezetnie minket.” (ford. tőlem) (A. Merkel 2016c)

A válságkezelést illető morális elköteleződés érvényesítése és védelme (például az integráció és az európai szolidaritás erősítése) kulcskérdése a merkeli vezetésnek. Ez határozza meg a válságértelmezését, a menekültek, az állampolgárok és az EU tagállamok szerepvállalását és kötelezettségeit, és persze a vezetés eszközeit és céljait. A helyes (morális) válságkezelés mellet a demokráciát, az európai értékközösséget, a liberális értékeket is meg kell védeni a szélsőséges politikával - a szélsőjobboldallal és a terrorizmussal - szemben. Mindennek a tétje a válság mélyülését jelentő morális veszélyekben tapintható ki:

„Ha Európa nem képes a menekültválságot kezelni, akkor az alapértékeit veszítheti el, nevezetesen azt az univerzális emberi jogokhoz való szoros kötődést, amely a közös Európánkat a kezdetektől meghatározta és amelyet továbbra is érvényesíteni kell.” (ford. tőlem) (A. Merkel 2015o)

Ezzel szemben az orbáni vízió a válság okozta bizonytalanság leküzdésére fókuszált, melyet a miniszterelnök maga is generált az események dramatizációjával. Ez a 
keresztény értékekre és az erős nemzetekre épülő Európa védelmét jelentette, amely egyszerre jelenti egy (régi-új) rend (Orbán-rezsim, új migrációs politika) kialakitását és védelmét, illetve a menekültpolitikát uraló liberális gondolkodás rombolását. Így a vezetésnek egyszerre kellett védekeznie a bevándorlással és az azt „támogató és elősegítő” liberális menekültpolitikával szemben. A narratíva olyan értékeket helyezett tehát a középpontba, mint a kereszténység, a nemzet, a szuverenitás, a demokrácia, a szólásszabadság és az Európai Unió vívmányai (a személyek szabad mozgása).

„[N]ekünk, magyaroknak ragaszkodnunk kell az önvédelem első számú alapelvéhez: azt, hogy kit engedek be a házamba, a hazámba, az országomba, és kivel fogok együtt élni, csak mi, magyarok dönthetjük el.” (Orbán 2016e)

„[M]i egyenesen és nyíltan beszélünk arról is, kimondjuk a véleményünket, hogy mi, magyarok azt szeretnénk, ha Európa az európaiaké maradna, és meg akarjuk őrizni Magyarországot is magyar országnak. Mindkét célunk legitim cél, meggyőződésem szerint mindkettő teljes összhangban van Európa alapértékeivel és az unió alapítóinak szándékával.” (Orbán 2015e)

Mindez nem jelentett reaktív pozíciót a vezetés számára. Orbán Viktor látta a vízióalkotás lehetőségét a válságban, pontosabban fogalmazva annak értelmezési lehetőségeiben:

„A migrációs válság pozitív következménye, hogy ismét nyíltan próbálunk beszélni földrészünk identitásáról, szabadabban, mint a két utóbbi évtizedben. A második pozitív következmény: ismét komolyan veszik a biztonság kérdését. Európa magától értetődőnek tartotta saját biztonságát az elmúlt húsz-harminc évben. Ez most ismét figyelmünk középpontjában áll. Harmadsorban ismét nagyobb jelentőséget tulajdonítanak a megoldásokra vonatkozó nemzeti nézeteknek. Korábban a »közös európai megoldásnak« sosem volt alternatívája.” (Orbán 2015a)

A védekezés mellett az orbáni politika célzottan kérdőjelezte meg és támadta az EU normatív hatalmát (Pace 2007) meghatározó liberális politikát, amely ebben az értelmezésben a multikulturalizmus és a politikai korrektség talaján állva nem akarta és nem is tudta kezelni a válságot, s így veszélyezteti a keresztény európai civilizációt és az EU eddigi eredményeit. Szűk értelemben az „új rend” kialakítása egy új nemzetállami bevándorláspolitikát jelentett. Tágabb értelemben viszont már Orbán az általa alapított rezsim politikai pozícióját kívánta nemzetközi szinten is erősíteni (Illés, 
Körösényi, és Metz 2018). Mindez kritikus feladatnak bizonyult annak fényében, hogy az új reszim egyes elemeit, mint az alkotmányozást, a alkotmánymódosítást, vagy az extenzív média szabályozást, folyamatos támadások érték az EU-s intézmények irányából (Sonnevend, Jakab, és Csink 2015). A migrációs válság hatására ebből a reaktív szerepből tört ki, vált offenzívé és vette át a kezdeményezést az orbáni politika, amely egyszerre erősítette a rezsimet belpolitikai szinten és hiteltelenítette el a rezsim „külső” kritikusait.

Alkalmasságát bizonyítva történetében ő testesíti meg, és ő is védi meg a „valódi Európát”. A józanész és a realitások populista politikáját szembeállította a dogmatikus, ideológiai és moralizáló vezetéssel:

„A shakespeare-i értelmezés szerint viszont a populisták azok az emberek, akik az ásót ásónak, a macskát macskának nevezik. Mi, magyarok nevén nevezzük a dolgokat. Ez része a mi természetrajzunknak.” (Orbán 2016m)

„Még nem késő, hogy az európai elit megértse de Gaulle tábornok leckéjét. Idézem. »A politikának a valóságon kell alapulnia, a politikában éppen az a művészet, hogy egy eszményért csak a realitásokon keresztül cselekedhetünk.« Idézet vége. A realitások pedig történelmiek, kulturálisak, demográfiaiak és földrajziak. Talán nem késő megértenünk, hogy a realitások nem a szabadság korlátai. A lecke, amit most tanulunk, arról szól, hogy a valósággal szemben nem létezhet szabadság. Legfeljebb politikai delírium és politikai kokainmámor. Hiába építjük föl a világunkat a legnemesebb eszmék iránti vágyból, ha nem a realitások talaján áll, csak vágyálom maradhat.” (Orbán 2016j)

Az orbáni értelmezésben ez a populista politika teszi képessé őt arra, hogy az európai elittel ellentétben a válságot helyesen (reálisan) értelmezze és a megfelelő célokat tüzze ki. A populizmus tehát vezetői erényekről (hitelesség, őszinteség és realitásérzék) árulkodik, amelyek Orbánt alkalmassá teszik a bizonytalanság leküzdésére (Európa és Magyarország megvédésére). Mindazonáltal a „tisztánlátás” és a „helyes” kihívásértelmezés még nem tesz egy vezetőt alkalmassá, ahhoz helyes (határozott és erélyes) politikai válaszoknak is kell társulniuk, amely már a taktikaalkotás tárgykörébe tartozik. 


\subsection{A taktikaalkotás}

A taktikaalkotás során már a vezető retorikai teljesítménye mellett, döntései és performatív cselekvése is kritikus. Kihasználva a rendelkezésre álló erőforrásokat, a vezetők eszközöket rendelnek a kitüzött közös célok eléréséhez. Az eszközök kiválasztásához azonban - legalábbis látszólag - a megfelelő politikai tudás birtokában kell lenniük. A másik irányból megközelítve: az eszközhasználatból következtetni lehet arra a politikai tudásra, melyre a vezető támaszkodik. Az erőforrások kihasználásához a vezetésnek össze kell hangolnia a vezetők akaratát és a követők cselekvését, amely az interakciók irányának, hatalmi kapcsolatának és a szerepeknek a rendezését vonja maga után.

Angela Merkel történetében a vízióhoz viszonyítva nagyobb hangsúly helyeződik a taktikaalkotásra. Amíg víziót a transzformatív vezetés jellemezte, addig a taktikaalkotást már egyértelmüen a tranzaktív vezetés elemei dominálták. Ahogy az identitásépítés kapcsán kirajzolódott a követőknek kölcsönösen aktív szerepet kell vállalniuk a probléma megoldásában: az állampolgárok fogadják be és segítsék a menekülteket, a menekültek illeszkedjenek be és tiszteljék a német társadalom liberális értékrendjét és az EU tagállamok vegyenek részt a menekültek szétosztásában. Ebből a szempontból kritikus volt a követők felhatalmazása és beemelése a politikába, amellyel a felelősség is megoszlik. Ez azt a feltételezést vonja maga után, hogy a hatalmat kollektív módon gyakorolják (power with) a követök a vezetővel. Ezt a képet azonban árnyalja, hogy Merkel reaktív módon csak követi az eseményeket: megoldja a felmerülő problémákat és kialakítja a megfelelő jogi kereteket, politikai kompromisszumokat és programokat. Az ő feladata válaszolni az igényekre, az aggodalmakra és kérdésekre, és elösegíteni azt, hogy konstruktív módon, bátran és önbizalommal közelítsék meg a problémákat.

Merkel tranzaktív vezetését jelképezi az optimizmust sugalló jelmondata, a „Megoldjuk” („Wir schaffen das”) fordulat. „[A]z én funkcióm az operatív cselekvés. Ez azt jelenti, hogy meg kell oldanom a problémákat. A megközelítési módom az, hogy meg tudjuk oldani [Wir schaffen das], mert mi egy erős ország vagyunk" (ford. tőlem) (A. Merkel 2015c). ${ }^{65}$ Ez vált Merkel vezetésének krédójává, amely mély meggyőződését és személyes felelősségvállalását jeleníti meg:

\footnotetext{
${ }^{65}$ Máshol így fogalmaz Merkel: S ,[m]inden német szövetségi kancellárjaként az én feladatom, hogy minden lehetséges módon azon problémák megoldásán dolgozzak, melyek foglalkoztatják az embereket. Ezen dolgozom minden erömmel.” (ford. tőlem) (A. Merkel 2015u)
} 
„[a] német egység gyermekeként világossá vált számomra, hogy újra új utakat kell majd járnunk, a bürokratikus akadályokat és a félelmeinket is le kell majd építenünk. A »megoldjuk« [Wir schaffen das] a helyes hozzáállás ehhez a feladathoz - célhoz és cselekvéshez.” (ford. tőlem) (A. Merkel 2016e)

A többes szám első személy („Wir schaffen das”) ellenére, mely a közös cselekvésre és hatalomgyakorlásra utal, Merkel sokat hivatkozik pozíciójára (,als Bundeskanzlerin”) és feladatára (,meine Aufgabe”), amelyből a hatalom mások feletti gyakorlása (power over) rajzolódik ki. Ez megmutatkozott abban is, hogy a politikai célokat (pl. integrációt és regisztrációt) Merkel jogi és politikai ösztönzéssel és akár kikényszerítéssel kívánta elérni. Ebböl az is következik, hogy a követök felhatalmazása szimbolikus maradt, amely nem eredményezte a vezető és követő kapcsolatának horizontálissá válását. Ez a pozicionális vezetésértelmezés egy hierarchikus, alá-fölérendeltséget leiíró, vertikális kapcsolatot feltételez mindamellett, hogy reaktív szerepet vállal fel a vezető.

Mindezen túlmenően a morális iránymutatást is némiképp felülírta egy pragmatista és feladat-orientált taktikaalkotás, amely a kemény hatalmi eszközök (szelektív ösztönzők és jogi szankciók) használata mellett megengedő módon a kompromisszumokat kereste. A válság nem merült ki morális kérdésekben, hanem egy megoldandó feladatot - egy „átfúrandó deszkát” (A. Merkel 2015r, 2015s) - jelentett Merkel számára Ebből a számszögből a merkeli politika egyszerre igényelt egy ideológiai és filozófiai tudást (episztémé), amely lehetőséget teremtve az értékalapú kapcsolódásra az identitásépítés, a helyzetdefiniálás és a vízióalkotás is megmutatkozott, és egy produktív, technikai tudást (tekhné), amely már a feladat, a probléma és a konfliktusok (konstruktív) megoldására fokuszál. Merkel erős morális elköteleződése és felelősségvállalása megkötötte ugyan a kezét, de egyszerü „gépészként” kívánta elérni és „legyártani” a maga elé kitűzött (morális) célokat. Leegyszerüsítve: bár a kihívások transzformatív vezetést láttattak, mégis a megvalósítás és a probléma megoldására használt eszközök már egy tranzaktív vezetésre vallottak. Ez a kettősség áthatotta a taktikaalkotást.

Fontos tudatában lenni annak, hogy a bevándorlás és a menekültek integrációjának kérdése a kezdetektől fogva meghatározó volt Merkel politikájában, de normatív tartalmat és morális igazolást csak a válság során kapott. A 2005-ben hatályba lépett „Bevándorlási törvény” újraszabályozta a menekültek belépését, tartózkodását, munkavállalását és integrációjukat. Merkel szakított a szigorú és az integráció kérdését mellőző menekültpolitikával, amely Helmut Kohl és még Gerhard Schröder vezetését is 
jellemezte. Arra is rámutatott, hogy a multikulturalizmus paradigmája kudarcot vallott és meghaladottá vált (Die Welt 2010). Tanulva a '60-as éveket követő menekültpolitikának hibáiból, Merkel politikájában már központi szerepet kapott az integráció kérdése. 2006-ban megtartották az első integrációs csúcsot, amelynek eredményeire alapozva a kormányzat 2007-ben kiadta a „Nemzeti Integrációs Tervet”. 2010-ben integrációs programot dolgoztak ki, amelyet egy nemzeti akcióterv követett 2012-ben. A merkeli integrációs politika lényegében kiegészítette a menekültpolitika europanizációját (Közös Európai Menekültügyi Rendszer, II. és III. Dublin rendelet). A paradigmára, mely probléma-centrikusan kötött össze több különböző szakpolitikai területet (rendvédelem, oktatás és egészségügy), a 2010-es években kezdték el széles körben használni a Willkommenskultur kifejezést, amely csak a menekültválság során vált normatív hívószóvá (Mushaben 2017b; Trauner és Turton 2017).

A válság új lökést jelentett a paradigmának, pontosabban felgyorsította annak fejlődését (5. táblázat). A merkeli válságkezelés fókuszai a következők voltak: (1) a menekültek regisztrálásának, fogadásának és ellátásának a rendezése, illetve ezen folyamatok gyorsítása (jogszabály módosítások, törvénycsomagok), (2) a nem jogosult bevándorlók számának csökkentése (biztonságos országok körének bővítése, EU-török megállapodás) (3) a menekültek integrálása (Integrációs Törvény), (4) a kérdés rendezéséhez a szolidaritás és az együttmüködés növelése az EU-ban (menekültkvóták).

Merkel morális válságértelmezése révén különösen ki volt téve olyan eseményeknek, melyek a humanitárius katasztrófára vagy a válság emberi arcára mutattak rá. Fordulópontként értelmezhető az a július 16-i eset, mikor a „Jó élni Németországban” („Gut leben in Deutschland”) címü polgári konzultáció keretében megtartott rostocki fórumon találkozott a fiatal palesztin menekülttel, Reem Sahwillel, akinek egy mütéti beavatkozás után, a családja az ország elhagyásával nézett szembe. Bejárta a német és nemzetközi sajtót az a felvétel, mikor Merkel vigasztalni próbálja a lányt, aki elsírja magát miután Merkel közölte vele, hogy nem fogadhatják be azokat, akik nem szorulnak védelemre. ${ }^{66}$ Reem története rámutatott a kancellár taktikájából kitűnő kettősségre. Ugyanis bár szimbolikusan a menekültek befogadása és integrálása döntő maradt, mégis Merkel pragmatikus módon szigorította menekültpolitikáját (bűnelkövetők kiutasítása, biztonságos származási országok körének kibővítése), és

\footnotetext{
${ }^{66}$ Merkel a következőképp szólt a lányhoz, miután meghallgatta történetét: „Megértelek (...) de néha a politika igen nehéz (...) Nagyon kedves személy vagy, de te is tudod, hogy még ezer és ezer hozzád hasonló ember van Libanon palesztin menekülttáboraiban, és ha azt mondjuk, hogy mindannyian jöhettek és még Afrikából is, akkor azt a helyzetet már nem tudnánk kezelni. (...) Ó Istenem."(idézi: Vick és Shuster 2015)
} 
kompromisszumokat (EU-török megállapodás) kötött hazai és nemzetközi szinten is.

5. táblázat: Merkel vezetésének idővonala a migrációs válság során 2015. január és 2016. szeptember között

\begin{tabular}{|c|c|}
\hline 2015. febru & Tartományi választások Hamburgban \\
\hline május 10. & Tartományi választások Brémában \\
\hline május 15. & Európai cselekvési terv közreadása a migrációs válság kapcsán \\
\hline július 16. & $\begin{array}{l}\text { Merkel találkozik Reem Sahwil palesztin menedékkérö lánnyal a „Jó élni } \\
\text { Németországban” c. polgári konzultáció keretében megtartott rostocki } \\
\text { fórumon }\end{array}$ \\
\hline augusztus 1. & $\begin{array}{l}\text { A tartózkodási jog és annak megszüntetésének újbóli meghatározásáról } \\
\text { szóló törvény hatálybalépése }\end{array}$ \\
\hline augusztus 24. & A Dublin (III) rendelet felfüggesztése a szír menekültek számára \\
\hline augusztus 26. & $\begin{array}{l}\text { Merkel meglátogatja a heidenaui menekülttábort, amelyet heves } \\
\text { migránsellenes tüntetés kísér }\end{array}$ \\
\hline augusztus 27. & Menekültek holttestének megtalálása egy teherautóban Ausztriában \\
\hline szeptember 4-5. & $\begin{array}{l}\text { A menekültek megindulnak gyalog Ausztria és Németország irányába } \\
\text { Budapestről }\end{array}$ \\
\hline szeptember 13. & $\begin{array}{l}\text { A schengeni megállapodás ideiglenes felfüggesztése a határellenörzés } \\
\text { visszaállitásával az osztrák határon }\end{array}$ \\
\hline szeptember 18. & $\begin{array}{l}\text { A Szövetségi Bevándorlási és Menekültügyi Hivatal vezetője, Manfred } \\
\text { Schmindt lemondott. Utódja Frank-Jüngen Weise lett, aki a Szövetségi } \\
\text { Munkaügyi Ügynökség vezetése mellett tölti be a pozíciót }\end{array}$ \\
\hline október 24. & Az első menekültügyi törvénycsomag hatálybalépése \\
\hline november 1. & $\begin{array}{l}\text { A külföldi gyermekek és fiatalok számára a lakhatás, a gondozás és a } \\
\text { segítségnyújtás javítására vonatkozó törvény hatálybalépése }\end{array}$ \\
\hline december 31. & $\begin{array}{l}\text { Szexuális támadások Kölnben és több német városban (Hamburgban, } \\
\text { Dortmundban, Düsseldorfban, Stuttgartban) }\end{array}$ \\
\hline 2016. február 5. & Az adatmegosztás javítását szolgáló törvény hatálybalépése \\
\hline február 27. & Terrortámadás Hannoverben \\
\hline március 13. & $\begin{array}{l}\text { Választások Baden-Württembeg, Rajna-vidék-Pfalz és Szász-Anhalt } \\
\text { tartományban }\end{array}$ \\
\hline március 17. & A második menekültügyi törvénycsomag hatálybalépése \\
\hline március 18. & Egyezség az EU és Törökország között \\
\hline április 16. & Terrortámadás Essenben \\
\hline július 18. & Terrortámadás Würzburgban \\
\hline július 22. & Terrortámadás Münchenben \\
\hline július 24. & Terrortámadás Reutlingenben és Ansbachban \\
\hline augusztus 6. & Az „Integrációs Törvény” hatálybalépése \\
\hline szeptember 4. & Választások Mecklenburg-Elö-Pomeránia tartományban \\
\hline szeptember 18. & Tartományi választások Berlinben \\
\hline
\end{tabular}

Merkel tranzaktív eszközválasztását szemléltette, hogy a kormányzat számos új törvényt és jogszabály-módosítást fogadtatott el. A 2015 augusztusában hatályba lépett szabályozás lefektette a menekültek tartózkodásának feltételeit, az integráció menetét és kötelezettségét, a védelemre nem szorulók körét, akik biztonságosnak ítélt országokból származnak, illetőleg a tartózkodási engedélynek a megvonását menedékkérelmek elutasítását követően. Az október 24-én hatályba lépő első menekültügyi csomag kibővítette Albániával, Koszovóval és Montenegróval a biztonságos országok körét, megnövelte a folyamatok finanszírozásának a helyi, tartományi és szövetségi keretét, 
kinyitotta és meggyorsította a társadalmi és gazdasági integrációs folyamatokat, de szabályozásra került a menekültek támogatási és juttatási rendszere is. 2015 év végén javították a külföldi gyermekeket és fiatalokat érintő lakhatást, gondozást és segítségnyújtást is. 2016 februárjában az adatmegosztás szabályozásával tették hatékonyabbá a menekültek regisztrációját. A második menekültügyi törvénycsomag 2016. március 17-én lépett hatályba, amely lehetővé tette a gyorsított eljárásokat, de korlátozta a családegyesítést, és a menekültek szabad mozgását, valamint szigorította az integrációs folyamatokat. Végül augusztus 6-án lépett hatályba az Integrációs Törvény, amely az integráció folyamatát, valamint az oktatáshoz és a munkaerőpiachoz való hozzáférést is szabályozta. Mindezzel Merkel új jogi keretet teremtett a Willkommenskultur politikájának.

Merkel morális (transzformatív) vezetését szimbolizálta, mikor Németország augusztus 24-én felfüggesztette a Dublin (III) rendeletet $^{67}$ a szír menekültek számára. Ezzel Németország kinyitotta kapuit a menekültek előtt, akik számára lehetővé vált, hogy az országban regisztráljanak függetlenül attól, hogy mely EU tagállam területére léptek be elöször. Két napra rá, először a válság során, Merkel személyesen meglátogatta a heidenaui menekülttábort is. Itt heves migránsellenes tiltakozás is fogadta, amely lényegében kihangsúlyozta morális felelősségvállalásának fontosságát. A legfontosabb elemmé az vált, hogy Merkel - az Alaptörvényre hivatkozva - a befogadandó menekültek számának felső határának meghatározását mindvégig visszautasította.

Mindazonáltal Merkel számára a legégetőbb gondot a menekültek fogadása és regisztrálása jelentette, amelyre már pragmatikus (tranzaktív) választ adott és lényegében kikényszerítette a regisztrációt. A helyzet akkor vált igazán tarthatatlanná, mikor szeptember 4-én a menekültek gyalog megindultak Budapestről Ausztria és Németország irányába. Az ellenőrizhetetlen módon Németországba érkező menekültek számának hirtelen megugrása szeptember 13-án maga után vonta a határellenőrzés visszaállítását az osztrák határon, azaz a schengeni megállapodás ideiglenes felfüggesztését. Így technikailag is lehetővé vált az újonnan érkező menekültek németországi regisztrálása. Ezt támogatta az is, hogy a menekültpolitika irányítása változáson ment keresztül, miután szeptember 18-án a Szövetségi Belügyminisztérium alá tartozó Bevándorlási és Menekültügyi Hivatal (Bundesamt für Migration und Flüchtlinge, BAMF) vezetője Manfred Schmidt - hivatalosan személyes okokra hivatkozva - lemondott. Utódja Frank-Jüngen Weise lett, aki a Szövetségi Munkaügyi

67 A III. Dublin rendelet előírja, hogy a menedékkérőket abban az országban kell regisztrálni és a menedékügyi eljárást lefolytatni, amelyben a menedékkérők beléptek az EU területére. 
Ügynökség vezetése mellett töltötte be a pozíciót. A menekültpolitika legfőbb szerve átfogó reformon is keresztülment, hogy kezelni tudja a megnövekedett számú kérelmeket. Új operatív igazgatóságok és kirendeltségek mellett a hivatal személyi állományát is kibővítették.

A szolidaritásra hivatkozva Merkel egy közös európai megoldást sürgetett, amely ugyancsak morális (transzformatív) vezetését szimbolizálta. 2015 májusában, a válság derekán az Európai Bizottság számos javaslatot (European Commission 2015a) dolgozott ki és terjesztett elő a szituáció feletti kontroll visszaszerzésének érdekében. Végül a Bizottság a cselekvési csomagot szeptemberben és decemberben adaptálta és tovább szélesítette. Az egyik legvitatottabb pont a kötelező áthelyezési (relocation) és betelepítési (resettlement) kvóta bevezetésének kérdése volt, amely Merkel taktikájának fontos elemévé vált föleg azt követően, hogy a dublini rendeletet Németország felfüggesztette. Amíg az áthelyezés a terhek megoszlását, addig a betelepítés a menekültek biztonságos és ellenőrzött belépését kívánta megvalósítani. A Bizottság szeptemberi javaslata értelmében 160.000 menekültet kell áthelyezni a következő két évben Olaszországból és Görögországból, azok tehermentesítése céljából. A magyar, a szlovák, a román és a cseh kormány tiltakozása ellenére a Tanács szabad utat adott a javaslatnak. Mindazonáltal a program nem minősült hatékonynak, hiszen egy év után, 2016. szeptember 21-ig csupán 5.651 menekült került áthelyezésre (European Commission 2016b). Hatékonyabb hosszútávú megoldásnak bizonyult az EU-török megállapodás, amely végleg lezárta a menekülthullám balkáni útvonalát és megerősítette az EU külső határvédelmét. Az egyezség a védelmet nem igénylő bevándorlók törökországi visszatoloncolását és a szír menekültek EU-ba való belépését (resettlement) segítette elö. 2016. szeptemberéig 10.695 menekült biztonságos és ellenőrzött belépését tették lehetővé az előirányozott 22.504 főből (European Commission 2016b). Összességében Merkel így már hatásos alternatívát is fel tudott mutatni a tagállamok egyoldalú akcióira (pl. a határzárra). ${ }^{68}$

Viszont 2016-ban már érezhetővé vált a merkeli menekültpolitika szigorodása, reagálva a Kölnben és több nagyvárosban szilveszterkor tapasztalt incidensekre, a terrorcselekmények sorozatára és a közvélemény változására. Egy március 17-én hatályba lépő törvénnyel szabályozásra került a bünöző külföldi állampolgárok

\footnotetext{
${ }^{68}$ Fontos itt megjegyezni azt is, hogy a partnerségi kapcsolatok bővítésének (például Jordániával és Libanonnal) lehetősége mellett, ugyancsak ezt a politikai irányt támogatta Merkel taktikájában a nemzetközi terrorizmus és az Iszlám Állam elleni harc, melyet a menekültválság kiindító okainak kezeléseként értelmezett.
} 
kiutasítása és a menekültstátusz megtagadási indokainak kibővítése. Továbbá a második menekültügyi törvénycsomaghoz kapcsolódott a biztonságosnak ítélt származási országok listájának Algériával, Marokkóval és Tunéziával való kibővítése is. Ennek elfogadását azonban a Szövetségi Tanács előbb elnapolta, majd 2017. március 10-én elutasította.

Összességében Merkel taktikaalkotása tükrözte a rá jellemző tranzaktív (pragmatista és feladat-orientált) vezetést. Ennek megfelelően taktikáját úgy alakította ki, hogy vezetése ugyan képes legyen reagálni a változó körülményekre és megoldani a felmerülő problémákat, de mégse adja fel a szimbolikus, morális felelősségvállalást és iránymutatást. Performatív cselekvéséböl jól kitünik, hogy feladatát jogi és közpolitikai oldalról közelítette és a bevett hatalmi eszközöket (pl. a határellenőrzés visszaállítása, a biztonságos országok meghatározása vagy a családegyesítés és a szabad mozgás tilalma) és szelektív ösztönzőket (például az integráció vagy az EU-Török megállapodás) használta.

Orbán Viktor helyzetértékelése és vízióalkotása - azaz a vezetése elött álló kihívások megfogalmazása - határozott és ellentmondást nem türő politikai és szakpolitika választ vetítettek elöre és kívántak meg. E mögött olyan opportunizmus és voluntarizmus húzódott, amely egyszerre irányult saját proaktív politikai pozíciójának a megerősítésére és érvényesítésére, valamint az új rend kialakítására és megszilárdítására:

„Az a legszebb része a mi szakmánknak, hogy folyamatosan, újabb és újabb gondolatok, megközelítések születhetnek, és ezért az optimista ember mindig láthatja azt, hogy az emberi akarat hogyan lesz úrrá a körülményeken. Ez a politikának a legszebb része.”(Orbán 2016h)

„A politika a lehetőségek művészete, azokat számba kell venni kellő időben.” (Orbán 2016g)

A követők az orbáni történetben reaktív szerepbe kényszerültek a válság hatására és a (proaktív) vezető védelmére szorulnak. Ez tükröződik az orbáni illiberális ${ }^{69}$ (értsd: antiliberális) (Orbán 2015j; ld. erről: Mándi 2015, pp. 24-30) demokrácia felfogásában is. Ennek értelmében a migrációs politikának a nép akaratán kell nyugodnia és annak

69 Összehasonlításképp érdemes Merkel gondolatait előhívni itt: „,[s]zámomra a demokrácia mindig a liberalizmusban gyökerezik. Saját pártomban, a Kereszténydemokrata Unióban három hagyományunk van: nevezetesen a keresztény-szociális, a liberális és a konzervatív, amelyekkel igen jól tudunk demokratikusan müködni. (...) Az „,illiberális” szóval a demokráciával kapcsolatban - őszintén szólva ezért sem tudok mit kezdeni." (ford. tőlem) (A. Merkel 2015f) 
védelmére kell irányulnia, ${ }^{70}$ amelyet a „Nemzeti konzultáció a bevándorlásról és a terrorizmusról” és a kvótareferendum volt hivatott becsatornázni. A népakarat követése érdekében a vezető akár intézményeket és procedúrákat is felülírhat:

„Az Európai Unió elvei, egyezményei, szabályai nincsenek kőtáblába vésve, nem istenek hozták, és nem is azok sugalmazták azokat, emberek alkották őket, éppen ezért az emberek bármikor meg is változtathatják. Ez a szabadság, és ez a demokrácia.” (Orbán 2015e).

Különösen kritikus pont ez annak fényében, hogy az orbáni értelmezésben az EU sui generis nem képes a demokratikus politikára (Orbán 2015a). Mindez tükrözi a vezérdemokrácia top-down politikai folyamatát, a vezetők és követők között fennálló vertikális irányú interakciókat és a karizmatikus vezetés hatalomértelmezését: a vezetőt itt a követök hatalommal ruházzák fel (power to), hogy rendezze a vélt vagy valós problémákat, amire ők maguk nem lennének képesek.

A bizonytalanság leküzdése és az alkalmasság bebizonyítása olyan határozott és erélyes politikai válaszokat és akciókat (6. táblázat) követelt meg, amelyekben tükröződnek a vezér politikai erényei és praktikus tudása (praxisz). Ennek megfelelően követve vízióját Orbán taktikája kettős volt. Egyrészt szigorú és kemény politikát szándékozott felmutatni a bevándorlással szemben, másrészt meg kívánta akadályozni az európai menekültpolitika implementálását.

70 „Föl kell tennünk a kérdést, hogy lehet-e helyes egy menekültpolitika, ha ellentétben van a népakarattal? Meg lehet-e változtatni egy-egy népnek a jövőjét, demográfiai összetételét, közbiztonsági helyzetét, kulturális mintázatát valami elvont, magasabb rendü eszme nevében úgy, hogy közben az emberek azt nem akarják? Itt összeütközik a liberalizmus és a demokrácia, a liberális és a demokratikus gondolkodás. A liberálisok azt gondolják, hogy ne lehetne, a társadalmak nem elég fölvilágosultak, értékeikben még nem elég modernek, ezért nekünk, vezetőknek az a dolgunk, hogyha kell, az emberek ellenében is érvényesítsünk néhány dolgot. Vannak a demokraták, mi magyarok ide tartozunk, akik azt mondják, hogy persze, előfordulhatnak ilyen viták, de alapvető kérdésekben, amelyek népek sorsát határozzák meg, nem az a kérdés, hogy mi mit gondolunk, hanem hogy mit gondolnak az emberek. Ezért meg kell őket kérdezni, meg kell őket hallgatni, és a véleményüket, döntésüket el kell fogadni. Itt összeütközik a liberális fölfogás és a demokratikus fölfogás. Magyarország egyértelmüen a demokraták, a demokratikus gondolkodású népek táborába tartozik." (Orbán 2016e) 
6. táblázat: Orbán vezetésének idövonala a migrációs válság során 2015. január és 2016. szeptember között

\begin{tabular}{|c|c|}
\hline 2015. február 20. & Parlamenti vitanap a megélhetési bevándorlásról \\
\hline április 24. & Nemzeti konzultáció a bevándorlásról és a terrorizmusról \\
\hline június & $\begin{array}{l}\text { Az első plakátkampány („Ha Magyarországra jössz...”) a nemzeti } \\
\text { konzultációval kapcsolatban }\end{array}$ \\
\hline június 17. & A déli határ lezárásának bejelentése \\
\hline június 30. & Parlamenti szavazás a biztonságos országokról \\
\hline július & $\begin{array}{l}\text { A második plakátkampány („A magyar reformok müködnek!”, „Nem } \\
\text { akarunk illegális bevándorlókat!”) }\end{array}$ \\
\hline július 13. & A szerb határzár kiépítésének megkezdése \\
\hline augusztus 1. & Életbe lépnek a szigorúbb migrációval összefüggö törvények \\
\hline szeptember 3-4. & $\begin{array}{l}\text { A menekültek menetelése a budapesti Keleti Pályaudvarról Ausztria } \\
\text { irányába }\end{array}$ \\
\hline szeptember 7. & Hende Csaba menesztése \\
\hline szeptember 14. & A déli határzár szerb szakaszának befejezése \\
\hline \multirow[t]{2}{*}{ szeptember 15.} & A migrációval kapcsolatos további jogszabályi szigorítás hatálybalépése \\
\hline & $\begin{array}{llccc}\begin{array}{l}\text { Kormányrendelet } \\
\text { kihirdetéséröl }\end{array} & \text { a tömeges bevándorlás } & \text { okozta válsághelyzet } \\
\end{array}$ \\
\hline szeptember 16. & A „,röszkei csata”: a menekültek összecsapnak a rendőrökkel \\
\hline szeptember 18. & Megkezdődik a déli határzár horvát szakaszának építése \\
\hline október 15. & A déli határzár horvát szakaszának befejezése \\
\hline november 16. & A Fidesz-KDNP elkezdi gyüijteni a kvóta-ellenes aláírásokat \\
\hline december 4. & $\begin{array}{l}\text { A magyar és szlovák kvótaellenes kereset nyilvántartásba vétele az Európa } \\
\text { Unió Bíróságán }\end{array}$ \\
\hline december 16. & A debreceni menekülttábor bezárása \\
\hline 2016. február 24. & A kormány népszavazást kezdeményez a kvótákról \\
\hline március 9. & A kormány az egész ország területére kihirdeti a válsághelyzetet \\
\hline április 28. & Megnyílik a körmendi menekülttábor \\
\hline május & $\begin{array}{l}\text { A harmadik plakátkampány („,Üzenjük Brüsszelnek, hogy ök is } \\
\text { megértsék!"). Ettől kezdve a plakátok a népszavazásra fókuszálnak }\end{array}$ \\
\hline június 7. & Az Alaptörvény 6. módosítása \\
\hline július & A negyedik plakátkampány („Tudta-e?”) \\
\hline szeptember & Az ötödik plakátkampány („Ne kockáztassunk!”) \\
\hline október 2. & A kvótaellenes népszavazás \\
\hline október 15. & A hatodik plakátkampány („,Megüzentük Brüsszelnek”) \\
\hline november 8. & $\begin{array}{l}\text { A miniszterelnök által benyújtott kvótákról szóló alkotmánymódosítás nem } \\
\text { szerzi meg a szükséges többséget }\end{array}$ \\
\hline
\end{tabular}

Az orbáni vezetés - a nemzeti hatáskör részeként - a törvényi szigorítás, a határok lezárása és fokozott védelme mellett kötelezte el magát. A határozott fellépést jelzi, hogy még a kérdéskörben indított nemzeti konzultáció befejezése elött, 2015. június 17én megszületett a kormányzati döntés a magyar-szerb határon épülő fizikai határzár felállításáról. Nyár végén az Országgyülés módosította a migrációval kapcsolatos jogszabályi keretet (a menedékjogi szabályozást, a Büntető Törvénykönyvet, a büntetőeljárási és a büntetések végrehajtásáról szóló törvényeket), amelyek miatt az év végén az Európai Bizottság kötelezettségszegési eljárást indított. A kérdés rendezésének sürgősségét mutatja, hogy szeptember 7-én a lassúnak talált kerítésépítés miatt Hende 
Csaba honvédelmi miniszter lemondásra kényszerült. ${ }^{71}$ A szeptember közepén elkészülő határzárat az év végére a horvát zöldhatárra is kiterjesztették. 2016. június 7-én a kormánypártok a Jobbik támogatásával elfogadták az Alaptörvény hatodik módosítását, amely a „terrorveszélyhelyzet” fogalmának bevezetésével a kormány vészhelyzeti hatalmát szélesítette ki. Az Országgyülés kétharmada terrortámadás közvetlen veszélye, vagy terrortámadás esetén - meghatározott időre - terrorveszélyhelyzetet hirdet ki, amellyel felhatalmazza a kabinetet rendkívüli intézkedések bevezetésére. Például rendeleti úton egyes törvények alkalmazását felfüggesztheti, és a törvényi rendelkezésektől eltérhet. A miniszterelnök a következőképp indokolta a módosítást: „Mi is csak annyit szeretnénk, azokat az eszközöket és olyan mozgásteret, amit más európai országoknak a saját parlamentjei megadnak.” (Orbán 2016d)

Ezt a képet ugyan árnyalja a kormány tudatos nem-cselekvése (Rácz 2015). A hatóságok tudatában voltak a közelgő menekülthullámnak, mégsem tették meg a szükséges lépéseket. Ennek eredményeképp kezelhetetlen helyzet alakult ki a tranzitzónákban („,röszkei csata”) és a migránsok utaztatása kapcsán, amely erősítette a migránsokról és a hatástalan és rossz európai menekültpolitikáról alkotott képet. Ebből a szemszögből a nem-cselekvés arra mutat rá, hogy az orbáni karizmatikus vezetés miként kívánta saját politikáját alátámasztva növelni a bizonytalanság látszatát.

Az orbáni taktika másik iránya az európai migránspolitika semlegesítése volt. A kötelező menekült kvóták teljes elutasítása mellett az EU-Törökország megállapodást is kritikával illette. Orbán Viktor az EU politikájának rombolására nagy hangsúlyt fektetett (lásd a harmadik plakátkampány üzenetét: „Üzenjük Brüsszelnek, hogy ők is megértsék!"). Mindezzel a vezető igyekezett erőforrásait, az állampolgári támogatottságot növelni így erősítve a vezetést az európai migránspolitikát illető kritikák mögött. Erre szolgált a vezetés plebiszciter stratégiája is. 2015. április 24-én nemzeti konzultációt indított el a kormány, amelyet plakátkampánnyal támogatott meg. A megfogalmazott tizenkét kérdésben és a hozzá csatolt levélben a migrációs válságot összekötik a terrorizmussal, megemlítik a migráció gazdasági vonatkozásait, valamint többször hangsúlyozzák a brüsszeli politika eredménytelenségét és negatív következményeit. 2016. október 2-án a kormány népszavazást rendezett a kötelező kvótáról. Bár az urnához járulók óriási többséggel elutasították a kötelező kvótának az Országgyűlés jóváhagyása nélküli bevezetését, a népszavazás az alacsony részvétel

\footnotetext{
${ }^{71}$ Orbán Viktor a miniszter távozásáról: „Nézze, van itt egy magyar rossz szokás (...). Ha egy magyarnak azt mondják, hogy a határidő harminc nap, akkor a harmincadik napon fog végezni, de az azt jelenti, az a legkésőbbi időpont." (Orbán 2015h)
} 
miatt érvénytelen maradt. ${ }^{72}$ A népszavazást követően a miniszterelnök indítványa nyomán újabb alkotmánymódosítás került napirendre, amelynek célja a kötelező kvóta a tervezet megfogalmazásában a „csoportos betelepítés” - megakadályozása. A kormány jobboldali ellenzéke, a Jobbik támogatása nélkül a módosítás azonban nem szerezte meg a kellő többséget.

Az orbáni vezetés nem állt meg az egyszerü kritikák megfogalmazásánál. Igyekezett erőteljes politikájával alternatívát felmutatni. Európai szinten a magyar migránspolitika egyes elemei, és azok megítélése különös pályán mozogtak: a teljes elutasítástól egészen az implicit és részleges elfogadásig, implementálásig. A fizikai határzárat ért kritikák ellenére egyre több ország épített ki, illetve kezdte meg kerítés telepítését határaira (időrendben: Ausztria, Szlovénia, Bulgária, Horvátország). Ezzel párhuzamosan az orbáni vezetés tudatosan használta a helyzetet a visegrádi négyek és saját politikájának megerősítésére. 2015 januárjától 2016 októberéig 14 alkalommal érintették a V4-ek vezetői a témát, amely során többször megerősítésre került a kötelező kvóta elutasítása. 2015 végén a szlovák és a magyar kormány együtt fordult az Európai Unió Bíróságához a Tanács kötelező kvótát előíró 2015. szeptember 22-i határozatával szemben. ${ }^{73}$

Összességében Orbán Viktor a karizmatikus vezetését alá tudta támasztani határozott és erélyes politikai válaszok megfogalmazásával. Másképpen fogalmazva: taktikájával bizonyította alkalmasságát (politikai tudását, erényeit és karizmáját) és egy új rend (egy új európai menekültpolitika) kialakítására tett erőfeszítéseit.

\subsection{A követők mobilizálása}

A vezetés eredményei és korlátai abban érhetők tetten, hogy a vezető mennyiben képes hatni másokra és mobilizálni a potenciális követőit. Fordítva megközelítve: az állampolgárok mennyiben fogadták el a vezető történetét és mennyire találták vezetését hitelesnek. Mindezt a vezetői hatásgyakorlás és az állampolgári preferenciák megváltozása felől közelítem meg.

A vezetői hatásgyakorlás a vezetők által a válságnak tulajdonított súlyában érhető tetten, amelyet két indikátorban kívánok megfogni: (1) az ezt tematizáló releváns szövegek arányában az összes megnyilatkozáson belül (2. ábra); (2) a téma súlyában

\footnotetext{
72 A népszavazásra bocsátott kérdésre: „Akarja-e, hogy az Európai Unió az Országgyülés hozzájárulása nélkül is elöírhassa nem magyar állampolgárok Magyarországra történő kötelező betelepítését?" 41,32\%, érvényes szavazat mellett 98,36\% nem szavazat érkezett (Nemzeti Választási Iroda 2016).

${ }^{73}$ A Bíróság végül 2017. július 26-án elutasította kereseteket.
} 
(részarányában) a releváns szövegeken belül. A releváns beszédek arányát (1) tekintve Merkel lényegesen kisebb súlyt (40\%) szánt a témának, mint Orbán (50\%). Ennek magyarázata egyrészt az, hogy amíg Merkel számára más fontos ügyek is felmerültek (például az ukrán válság), addig Orbán az ország közvetlen kitettségének megszünését követően is nagy figyelmet szánt a kérdésnek. Noha 2015 novemberére az érintett határszakasz teljes lezárását követően nagymértékben csökkent az illegális határátlépők száma, ${ }^{74}$ a kérdés súlya a magyar miniszterelnöknél csökkenés helyett növekedett.

5. ábra: A releváns beszédek aránya 2015. január és 2016. szeptember között ${ }^{75}$

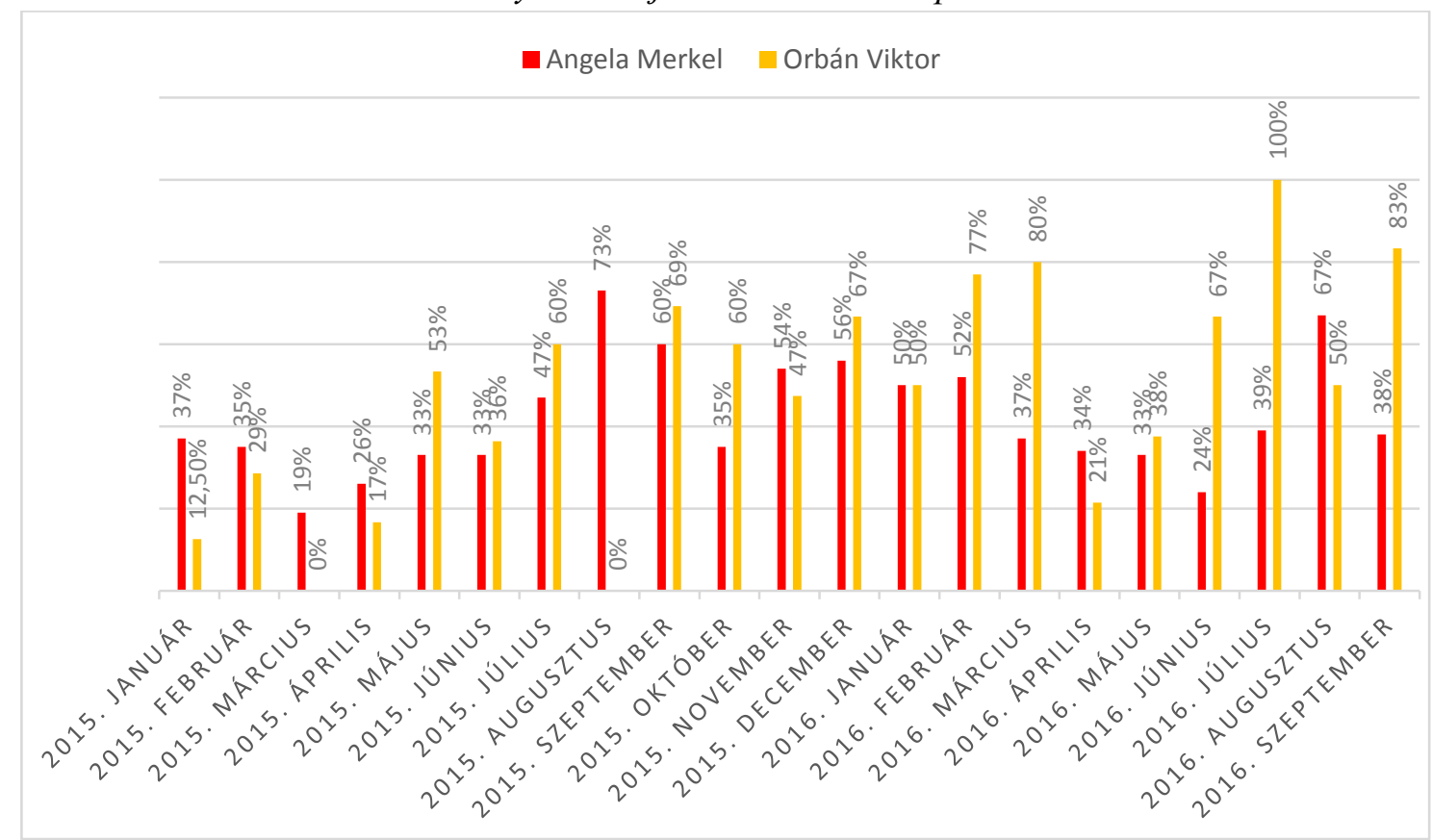

Forrás: saját gyüjtés

A releváns szövegeken belül a kérdésre fordít figyelem (2) nem mutat nagy eltérést Merkel (48\%) és Orbán (50\%) között. Orbán esetében a releváns szövegeken belül a téma részarányának növekedése párhuzamot láttat az illegális határátlépők számának megugrásával. Az átlagos 51\%-os arányához mérten kiugró mértékben érintette a témát a legkritikusabbnak számító időszak, 2015. július - október között, amikor ez az érték 71\% volt. Azonban a kitettség csökkenésével ez az arány nem csökkent. Például a 2016. október 2-i népszavazást megelőző időszakban a 79\%-os átlagot is elérte. S bár Merkel esetében is tapasztalható volt $^{76}$ növekedés, de a mutató csak két hónapban (2016 februárjában és márciusában) érte el a 60\%-ot. Orbán szándékát talán a legszemléletesebben a beszédek és az interjúk esetében leírt arányok mutatják. A mintában mindkét típus erősen, de egyenlő mértékben túlreprezentáltnak bizonyult: a

\footnotetext{
${ }^{74}$ Az illegális határátlépők havi összesített száma 2015-ben októberről novemberre 99.497-ről 315 főre zuhant.

752015 augusztusában egyetlen megnyilvánulást sem rögzítettem Orbán Viktor esetében.

${ }^{76}$ A 2015 júliusi 21\%-os arány augusztusra elérte az 50\%-ot.
} 
102 darab szövegből 37 beszéd és 40 interjú volt. Amíg a beszédek esetén a releváns szövegrészletek aránya $40 \%$ volt, amely $11 \%$-kal kevesebb, mint a minta átlaga, addig ez az interjúk esetében $62 \%$ volt, amely 11\%-kal meghaladta az átlagos értéket. Az interjúk, amelyeket túlnyomó többségében a kormányközeli médiumok adtak közre, lehetőséget biztosítottak Orbán Viktor számára, hogy részletesen kifejtse álláspontját. Ezzel szemben Merkel esetében többségben voltak a sajtókonferenciák ( 86 db, 49\%), amelyek a riporterek kérdései nyomán bizonytalanabb közeget teremtenek és reaktív pozícióba kényszerítik a vezetőt. Mindazonáltal ez illeszkedni látszott Merkel vezetésfelfogásához és mobilizálási stratégiájához.

Az orbáni történet a kérdésre helyezett nyomatékát láttatja a már említett 2015-ös nemzeti konzultáció és a 2016-os népszavazás, illetve a hat egymást követő médiakampány. Az első 2015 májusában indult, a nemzeti konzultációt támogatva. Ennek tartalma a válság természetét kívánta meghatározni, kiemelve annak a kultúrára, a közbiztonságra és az életkörülményekre gyakorolt várható hatását. A magyar reformokat népszerüsítő kampány keretében a „Nem akarunk illegális bevándorlókat” üzenet került megfogalmazásra. A népszavazást támogató három kampány üzeneteiben nyíltan a brüsszeli politikát kritizálta, és emelte a válság tétjét a migráció és a terrorizmus összekapcsolásával és a migrációs nyomás érzésének fenntartásával.

A vezetőknek a közvéleményre gyakorolt hatását tekintve érdemes megfigyelni az általános politikai támogatottság alakulását. Merkel, mint a második legnépszerübb német politikus, személyes támogatottsága (elfogadottsága) (6. ábra) messze megelőzi a pártjáét. A közvélemény-kutatások adatai alapján elfogadottsági indexe a válság nyomán erősen csökkenni kezdett. Ezt a negatív pályát erősítették a kölni események, a terrorcselekmények, valamint a megjelenő ellenmobilizáció. Mindazonáltal Merkel időről-időre visszaszerezte a németek bizalmát. Ezzel szemben pártja, a német Kereszténydemokrata Unió (Christlich Demokratische Union Deutschlands, CDU) támogatottsága 10\%-os esést mutatott az időszakban (7. ábra).

Ez a tendencia mutatkozott meg a 2015-16-os évi tartományi választási eredményekben is (BAMF 2016b, p. 18, 2017, pp. 18-19). A CDU számára az időszak hét tartományi választása egyaránt kudarcot vallott. Bár a 2015 első felében tartott brémai és hamburgi választásokon is csökkenést (Hamburg) vagy stagnálást (Bréma) mutatott a párt támogatottsága, mégis a negatív tendencia a 2016. március 13-án tartott három tartományi választáson (Baden-Württembeg, Rajna-vidék-Pfalz és Szász-Anhalt), s a később, szeptemberben Mecklenburg-Elö-Pomerániában és Berlinben tartott 
választásokon volt igazán szembetünő. Ezeken a választásokon a csökkenés mellett egyre erősebb politikai pozíciót harcolt ki magának a migrációellenes, radikális jobboldali Alternatíva Németországért (Alternative für Deutschland, AfD) is. Összességében azonban a tartományok politikai irányvonala nem változott meg, azaz továbbra is támogatták a menekülteket befogadó és integráló politikát (BAMF 2016b, p. 18, 2017, pp. 18-19). Tehát a merkeli politika támogatottsága időről-időre stabilizálódott, mégis erős ellenmobilizációt eredményezett. Ennek középpontjában az AfD mellett a bevándorlás- és iszlámellenes PEGIDA (Patriotische Europäer gegen die Islamisierung des Abendlandes) volt, amely tüntetések sorozatával és populista üzenetekkel (,Wir sind das Volk”) hívta fel magára a figyelmet. Ezzel párhuzamosan a németek többsége 2016 elején már nem volt optimista azt illetően, hogy a menekültkérdést meg tudják-e oldani (,Wir schaffen das”) (Infratest dimap 2016d).

6. ábra: Angela Merkel elfogadottsági indexének alakulása 2015. január és 2016. szeptember között ${ }^{77}$

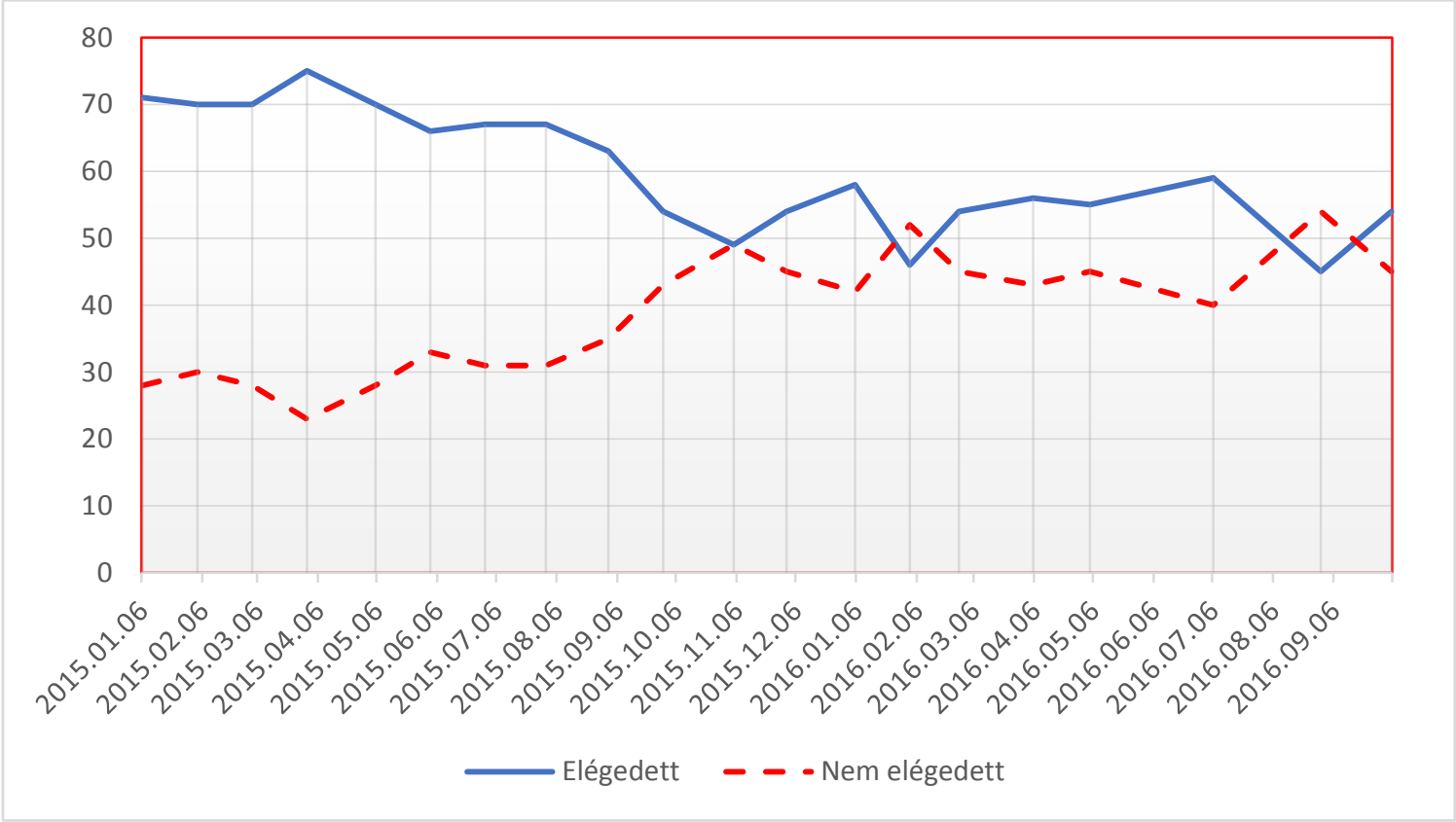

Forrás: ARD-DeutschlandTREND Infratest dimap

\footnotetext{
${ }^{77}$ Infratest dimap kérdése: „Und nun geht es um Ihre Meinung zu einigen Spitzenpolitikern. Wie ist das mit...? Sind Sie mit ihrer/seiner politischen Arbeit sehr zufrieden, zufrieden, weniger zufrieden oder gar nicht zufrieden?"
} 
7. ábra: A CDU/CSU támogatottsága 2015. január és 2016. szeptember között a pártot választani tudó biztos szavazók körében

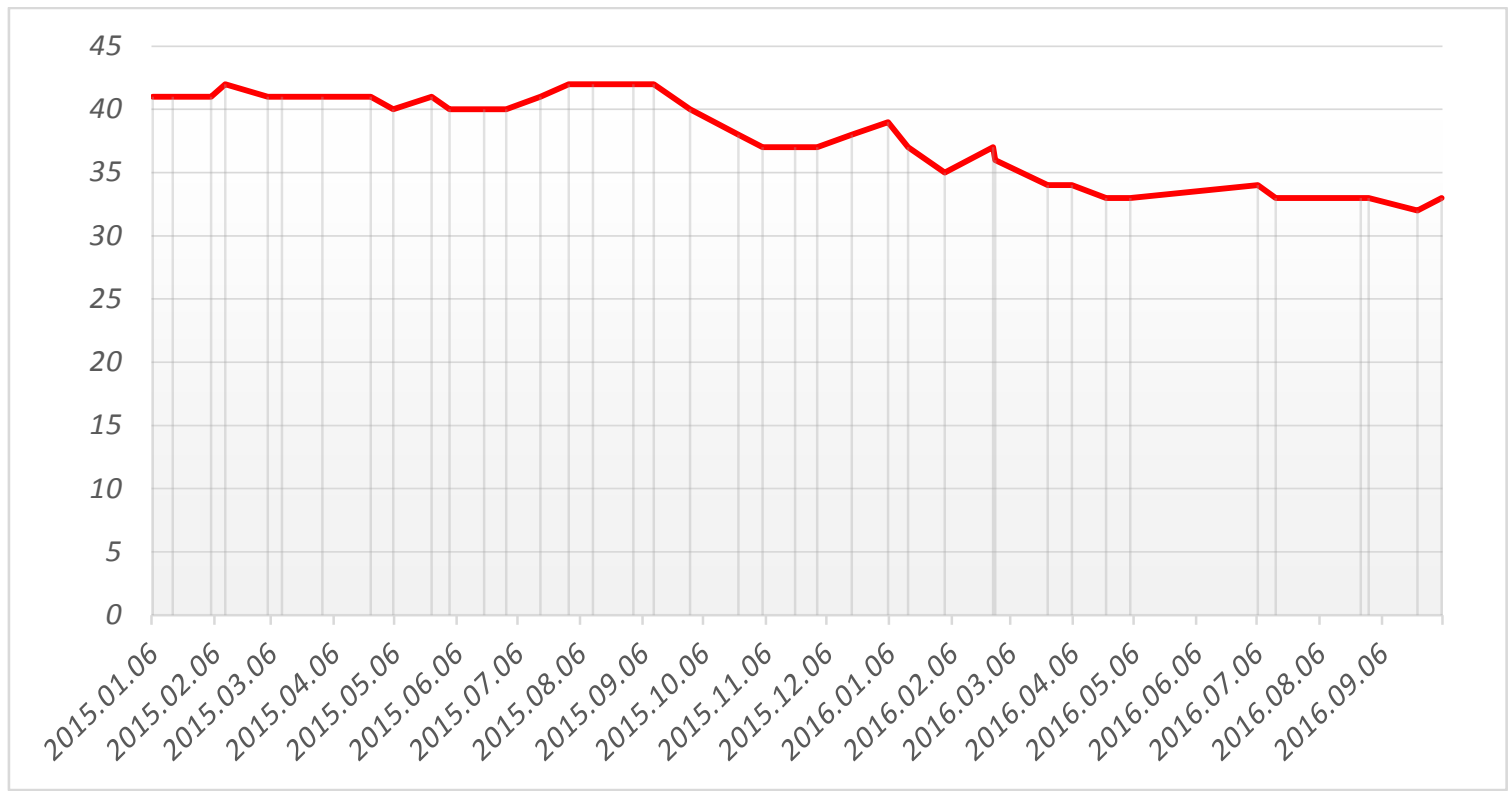

Forrás: ARD-DeutschlandTREND Infratest dimap

Merkel helyzetét a kompromisszumkereső „középutassága” sem feltétlenül segítette, ugyanis amíg saját- és testvérpártjában, a Bajor Keresztényszocialista Unióban (Christlich-Soziale Union in Bayern, CSU) erősödtek a menekültpolitika szigorítását követelő hangok (Horst Seehofer), addig koalíciós partnere, a német Szociáldemokrata Párt (Sozialdemokratische Partei Deutschlands, SDP), bár megosztott volt a kérdést illetően ${ }^{78}$, de ellenkező irányú kritikát fogalmazott meg a menekültpolitika szigorítása kapcsán. Mindazonáltal - meglepő módon - a Szövetség '90/Zöldek (Bündnis 90/Die Grünen) viszont támogatta a merkeli nyitott ajtók politikáját.

A közvélemény bizalma, bár a válság során megrendült mind az EU-t, mind a nemzeti törvényhozást és kormányt illetően, mégis helyreállni látszott 2016 végére. ${ }^{79}$ Ezt a tendenciát követte a kérdés fontosságának a megítélése is. ${ }^{80} \mathrm{~A}$ kérdés jelentősége, bár a vizsgált időszakban végig megmaradt, a 2015 második felében tapasztalt kiugrást

\footnotetext{
${ }^{78}$ Sigmar Gabriel, alkancellár és Joachim Gauck, szövetségi elnök is kritikával illették a merkeli politikát. Gauck például úgy fogalmazott 2015 szeptemberében, hogy: „[a] mi szívünk nagy, de a lehetőségeink korlátozottak." (Zeit Online 2015)

${ }^{79} \mathrm{Az}$ Eurobarometer (European Commission 2015b, 2015c, 2016c, 2016d) szerint az értékek a következőképp alakultak. EU-t övező bizalom: 39\% (2015. július), 28\% (2015. december), 28\% (2016. július), 37\% (2016. december). A nemzeti törvényhozást övező bizalom: 53\% (2015. július), 42\% (2015. december), 41\% (2016. július), 55\% (2016. december). A nemzeti kormányt övező bizalom: 50\% (2015. július), 38\% (2015. december), 39\% (2016. július), 51\% (2016. december).

${ }^{80}$ Az Eurobarometer féléves jelentései (European Commission 2015b, 2015c, 2016c, 2016d) szerint a következőképp alakult azok aránya, akik a két legfontosabb országos kérdés közé sorolták a migrációt Németországban: 46\% (2015. július), 76\% (2015. december), 56\% (2016. július), 45\% (2016. december). Ennek az értéknek az alakulása az EU-val kapcsolatban: 56\% (2015. július), 76\% (2015. december), 57\% (2016. július), 50\% (2016. december).
} 
követően az index visszaállt a kiinduló állapot szintjére. Fontos látni, hogy a németek ugyanakkora szerepet szántak az EU-nak és saját kormányuknak a kérdés rendezését illetően (Magyarországgal ellentétben). S ilyen értelemben a probléma megoldásában vezető szerepet szántak Németországnak egész Európát illetően. Erre lehet bizonyíték az is, hogy az intézmények bizalmi indexének változása is párhuzamosan változott a probléma megítélésével.

A menekültválsággal és a válságkezelő politikával kapcsolatos attitüdök is változtak. A válság kezdetén a németek túlnyomó többségét, 88\%-át sikerült mobilizálni, hogy valamilyen formában (adományozással vagy önkéntes munkával) járuljon hozzá a válság rendezéséhez (Helms, Van Esch, és Crawford 2018, p. 10). A közvélemény-kutatások rámutattak arra, hogy a németek egyre kevésbé támogatták a menekültek befogadását. ${ }^{81}$ Viszont a németek jelentős többsége továbbra is támogatta a háború, a katasztrófák, vagy a politikai és vallási okok miatt útra kelő menekültek befogadását, de a gazdasági, munkavállalási motivációt egyre inkább elutasították. ${ }^{82}$ Fontos aláhúzni, hogy a menekültekkel kapcsolatos félelem ${ }^{83}$ is növekedett, de ezeket a félelmeket igen vegyes indokok váltották ki (Infratest dimap 2015b). Voltak, akik féltek a szélsőjobboldali pártok térnyerésétől, voltak, akik a gazdasági következményektől (munkaerő- és lakáspiac) tartottak, de erős indoknak számított az iszlamizálódás, a bűnözés növekedése és a terrorizmus is. Ezzel párhuzamosan egyes elemzések az idegenellenesség növekedését mutatták ki (Deutsche Welle 2016), amelyet a gyülöletbűncselekmények növekedése is láttathat. ${ }^{84}$ Összességében Merkel menekültpolitikájával többnyire elégedetlenek voltak a német állampolgárok (Infratest dimap 2015c, 2015d, 2015b, 2016a), amely mögött azonban egyszerre volt a menekültpolitika szigorításának és enyhítésének az igénye. Így a merkeli vezetés megítélése „két tűz” került.

\footnotetext{
${ }^{81}$ Az Infratest dimap közvélemény-kutató cég kutatása szerint 2015 elején a németek 73\% fogadott volna ugyanannyi vagy több menekültet, mint az azt megelőző időszakban (Infratest dimap 2015a), de 2015 szeptemberében már csak 59\%-an gondolták ugyanezt (Infratest dimap 2015c). Ezzel párhuzamosan erősödött az a vélemény, amely már a menekültek érkezését is negatív színben látta (Infratest dimap 2015c, 2016c).

${ }^{82}$ A közvélemény-kutatások szerint 2015 elején a válaszadók 41\%-a elfogadta, míg 55\%-uk nem fogadta el ezt a motivációt. A gazdasági menekültek elfogadása viszont 2016 februárjára 25\%-ra esett vissza (Infratest dimap 2016b).

${ }^{83}$ A menekültekkel kapcsolatban a németek 38\%-a érzett valamilyen félelmet 2015 szeptemberében (Infratest dimap 2015c). 2016 januárjában viszont már 48\%-uk vélekedett hasonlóképp (Infratest dimap 2016d).

${ }^{84}$ A Szövetségi Bünügyi Rendőrség 2015-ben 1029 menekültszállás ellen elkövetett büncselekményt rögzített, amelynek száma az azt megelőző évekhez képest megnégyszereződött. Ezen büncselekmények közül 177 volt erőszakos támadás (BAMF 2016b, p. 20). 2016-ban 983 büncselekményt követtek el a menekültszállások ellen és 217-et a támogató szervezetek ellen. Ebben az évben összesen 2.545 büncselekményt követtek el menekültek sérelmére (BAMF 2017, p. 21).
} 
Bár Merkel pozíciója összességében elbizonytalanodott, politikájának megítélése stagnált vagy romlott, elfogadottsági indexét sikerült megmentenie. Azonban a merkeli vezetés rugalmasságáról és alkalmazkodóképességről árulkodik az, hogy kompromisszumkereső módon a szigorítás irányába mozdult el, de végig megtartotta erős morális alapjait. Így a merkeli vezetéshez a követők egyszerre tudtak érték és érdek alapon is kapcsolódni. Merkel válságértelmezését és -kezelését ugyan erős kritikák érték, mégis transzformatív vezetése (a morális iránymutatása és a követők felhatalmazása) kompatibilis volt és maradt a baloldal humanitárius és morális érvelésre épülő válság narratívájával. Például saját szavazóit megelőzve a Zöld-párti választók voltak leginkább megelégedve Merkel menekültpolitikájával (Infratest dimap 2015b, 2016a). Mindazonáltal a célok elérésében (taktikaalkotásban) megmutatkozó tranzaktív vezetéssel korrigálva politikáját, képes volt reagálni a változó körülményekre és a közvélemény változására. Mindennek eredményeként sikerült történetét és vezetését elfogadtatni, pozícióját megőriznie és politikájának főbb irányát megvédenie a vizsgált időszakban.

Az orbáni politika megítélése eltérő képet látatott. Orbán népszerüsége egyértelmü növekedést mutatott. Bár hiányos adatok állnak rendelkezésre a miniszterelnök népszerüségét (alkalmasságának megítélését) illetően, mégis jól kivehető, hogy a menekültválság hatására sikerült jelentősen javítania pozícióján. ${ }^{85}$ Ezzel szemben a kormánypárt támogatottsága 2015 januárja és 2016 októbere között a közvélemény-kutató cégektől függően csak 7\% körüli értékkel növekedett, amellyel nem érte el az előző választásokat megelőző állapotot. ${ }^{86}$

Az orbáni vezetés ennél talán még sikeresebbnek bizonyult abban, hogy maga mellé állította a közvélemény nagy részét a válságértelmezést és taktikaalakítást illetően. Másképpen fogalmazva a vezetés migránsválságot illető helyzetértékelése megtalálta a szélesebb közönségét. 2014 ősze óta a kérdés fontosságának a megítélése ugrásszerűen

\footnotetext{
852014 végére Orbán népszerüsége mélypontra zuhant: a Medián adatai alapján 32\%-ra esett (Kisistók 2014). Azonban a migrációs válság nyomán nagy mértékben, 38\%-ról (2015. április) 44\%-ra (2015. szeptember), növekedett (Medián 2015b). Ez a tendencia 2017 elejére is kitartott, mikor Orbán népszerüsége elérte a 49\%-ot (2017. február) (Origo 2017) Itt fontos kitérni a vezetők megítélésére vonatkozó indexek különbségére. Amíg a fentebb használt Infratest dimap adatai a politikusokkal való elégedettségre mutatnak rá (az elemzésben ezt elfogadottsági indexnek nevezem), addig a Medián közvélemény-kutatásai a politikusok népszerüségére kérdeznek rá. A Medián módszertana azonban „szívesen látná fontos politikai szerepben” - sokkal inkább a politikusok alkalmasságát méri. Túl a módszertani különbségeken a következő, 9. fejezetben elemzett brit vezetők esetében mindkét mutató rendelkezésre állt.

86 2015. január és 2016. október között a Fidesz támogatottságának változása a teljes népességben: Medián (2015. 02. - 2016. 09.): +10\%; Tárki (2015. 01. - 2016. 10.): +8\%; Századvég (2015. 01. - 2016. 10.): $+3 \%$; Nézőpont (2015. 01. - 2016. 10): $+8 \%$. (Forrás: saját gyüjtés)
} 
megnőtt az ország és az EU politikáját illetően is. ${ }^{87}$ Ezzel párhuzamosan az EU megítélése jelentősen romlott, amely arra utalhat, hogy a vezetésnek sikerült meggyőznie a választópolgárokat arról, hogy az EU által kínált válságkezelés nem megfelelő. Az EU-ba vetett intézményi bizalom a 2015 tavaszi 56\%-os értékről egy év leforgása alatt 41\%-ra zuhant. Noha az EU-t pozitívan megítélők köre is 10\%-os csökkenést mutatott 2016 első feléig, mégis év végére a mutató újra növekedni kezdett. ${ }^{88} \mathrm{~A}$ válság tétjének növelése és a bünbakok kijelölése tehát részben sikeresnek bizonyult. Ugyanakkor a nemzeti intézményeket - a parlamentet és a kormányt - illető bizalom egyáltalán nem növekedett, sőt 2016 első felében némi csökkenést is mutatott. ${ }^{89}$ Mindebből arra következtethetünk, hogy bár a kérdést kiemelkedő fontosságúnak ítélték meg a magyarok, de mind a kialakult helyzettel, mind a lehetséges megoldással kapcsolatban a felelősséget az EU-nak tulajdonították, s nem az ország vezetésének.

Túl a kötelező kvóta elutasításán, a vezetés taktikai lépéseit a közvélemény széles körben elfogadta. ${ }^{90}$ A határzár megítélését a közvélemény-kutató cégek eltérően mérték, viszont mindegyik arra az eredményre mutatott rá, hogy a válaszadók döntő többsége támogatta a kormány intézkedéseit. ${ }^{91}$ A Medián (2015a) 2015. szeptemberi kutatásában az illegális határátlépés bűncselekménnyé nyilvánítását támogatók körét 63\%-ra mérte, mely erősen keresztbe metszette a pártpreferenciákat. A Századvég (2015b) 2015. január és szeptember között 12\%-os növekedést mutatott ki a szigorúbb bevándorláspolitikát inkább támogatók körét illetően.

Ahogy az EU-val kapcsolatos negatív tendenciák, úgy a bevándorlókkal kapcsolatos attitűd is jól láttatja, hogy a csoporton kívüliek megformálása sikeresnek bizonyult. A vezetés tudatos nem-cselekvéssel generálta a választók mediatizált tapasztalatát a migránsokról és a migrációról. 2016-ra ugrásszerüen, 12\%-ot nőtt az idegenellenesség

\footnotetext{
${ }^{87} \mathrm{Az}$ Eurobarometer féléves jelentései szerint (European Commission 2015b, 2015c, 2016c, 2016d) a következőképp alakult azok aránya, akik a két legfontosabb országos kérdés közé sorolták a migrációt Magyarországon: 13\% (2015. július), 34\% (2015. december), 28\% (2016. július), 30\% (2016. december). Mindemellett a migráció esetében 2015 öszén 68\%, 2016 tavaszán 67\% magyar megkérdezett jelölte azt az EU legfontosabb ügyének.

${ }^{88} \mathrm{Az}$ Eurobarometer (European Commission 2015b, 2015c, 2016c, 2016d) szerint az értékek a következőképp alakultak. Az EU-t övező bizalom: 56\% (2015. július), 41\% (2015. december), 41\% (2016. július), 42\% (2016. december). Az EU-t pozitívan megítélők aránya: 43\% (2015. július), 39\% (2015. december), 33\% (2016. július), 37\% (2016. december).

$89 \mathrm{Az}$ Eurobarometer (European Commission 2015b, 2015c, 2016c, 2016d) szerint a nemzeti törvényhozást övező bizalom: 31\% (2015. július), 30\% (2015. december), 26\% (2016. július), 30\% (2016. december). Míg a nemzeti kormányt övező bizalom a következőképp alakult: 34\% (2015. július), 33\% (2015. december), 30\% (2016. július), 35\% (2016. december).

${ }^{90}$ Lásd Juhász és Molnár (2016, pp. 284-85) által összegyüjtött közvélemény-kutatásokat a kötelező kvótákkal kapcsolatban.

91 A határzár támogatottsága: Századvég 61\% (Századvég 2015a), Nézőpont Intézet 55\% (Nézőpont Intézet 2015) Medián 68\% (Medián 2015a).
} 
az elöző évben mérthez képest, amely a kutatás kezdetétől, 1992-től mért legmagasabb érték (Tárki, 2016). Sőt ez az érték 2017-re további növekedést mutatott (Sik 2017)

Összegezve: a magyar miniszterelnök elsősorban saját táborához szólt, kizárva ezzel a mobilizálás szélesítését. Noha az orbáni történetet elnyerte közvetlen táborának teljes támogatását és egyes elemeivel (az EU és az idegenek szerepe, válság definiálása és kezelése) a szélesebb politikai közösség is szimpatizálni tudott, Orbán mégsem tudta növelni támogatottságát olyan mértékben, ahogy a preferenciák alakulásából az feltételezhető volt. Erre utalhat a népszavazás érvénytelensége, illetőleg az, hogy a nemmel szavazók mindössze 76.968 fővel voltak többen azokhoz képest, akik a kvótát nyíltan elutasító pártokra együttesen szavaztak 2014-ben. ${ }^{92}$ Ugyancsak sokat mond az is, hogy noha az EU-ba vetett bizalom csökkenő tendenciát mutatott, a parlament és a kormány bizalmi indexe stagnált. Mindez viszont elsősorban nem a baloldali ellenzék és civilek ellentétes irányú tevékenységének volt köszönhető (Szalai és Gőbl 2016), hanem sokkal inkább az orbáni vezetés belső korlátainak. Az Orbán által megformált karizmatikus vezetés személyére irányuló érzelmi kötődést kíván meg a követőitől. Azaz: a követők nem érték- vagy érdekazonosság alapján mérlegelnek a vezetők között és így a vezetői történet egyes elemeinek a támogatása nem eredményez egyértelmüen követést. Ebböl a szemszögből a korlátok ellenére is, a követők mobilizálása sikeresnek bizonyult, hiszen saját követőinek táborát egyben tartotta, erősítette és kismértékben szélesítette is azt.

\section{7. Összegzés}

A menekült- vagy migrációs válság élesen rávilágított a helyes demokratikus vezetés igényére és szükségességére. A fejezetben tárgyalt két vezető eltérőképpen viszonyult a válsághoz és a vezetéshez, amely következményeképp megítélésük is éles kontrasztot mutatott. A vezetői történetek strukturálása során kirajzolódtak azon szempontok és elemek, amelyek alapján a különböző demokratikus vezetéstípusok felismerhetőkké váltak és végeredményében a két vezető közötti különbség kikristályosodott ( 7 . táblázat). Fontos aláhúzni, hogy a kutatás itt nem kívánja azt állítani, hogy egyik vagy másik vezető morális vagy hatékonysági szempontok mentén ,jobb” lett volna, csupán arra mutat rá, hogy a vezetők az adott kontextusban eltérő demokratikus vezetést kívántak érvényesíteni.

\footnotetext{
92 A népszavazáson nemmel szavazók száma: 3.362.224 (Nemzeti Választási Iroda 2016). A 2014-es parlamenti választáson a Fideszre és a Jobbikra szavazók száma: 3.285 .256 (Nemzeti Választási Iroda 2014).
} 


\begin{tabular}{|c|c|c|}
\hline & Angela Merkel & Orbán Viktor \\
\hline \multicolumn{3}{|c|}{$A$, jó" vezetés } \\
\hline Kihívások & \begin{tabular}{l} 
morális alapítás (német és európai \\
társadalom, mint „Willkommenskultur”) \\
- $\begin{array}{l}\text { morális iránymutatás } \\
\text { (menekültválság, mint morális }\end{array}$ \\
kérdés) \\
követők beemelése a politikába (civil \\
társadalom mobilizálása, menekültek \\
integrálása) \\
- konstruktív problémamegoldás \\
(követők transzformációjának \\
elösegítése) alárendelése a közérdek \\
kialakításának (integráció, mint \\
gazdasági és demográfiai lehetőség) \\
(tranzaktív vezetés < transzformativ \\
\multicolumn{2}{c}{ vezetés) }
\end{tabular} & $\begin{array}{l}\text { bizonytalanság leküzdése (az ország és } \\
\text { Európa védelme a migránsválság, az } \\
\text { identitásválság és demokráciaválság } \\
\text { hatásaitól) } \\
\text { - az alkalmasság bebizonyítása } \\
\text { (populizmus, mint a hitelesség, az } \\
\text { őszinteség és a realitásérzék } \\
\text { tanúbizonysága) } \\
\text { új rend kialakítása (egy új nemzeti és } \\
\text { keresztény értékeken alapuló } \\
\text { migrációs politika, az Orbán-rezsim } \\
\text { védelme) } \\
\text { (karizmatikus vezetés) }\end{array}$ \\
\hline Politikai tudás & $\begin{array}{l}\text { tekhné (taktikaalkotás: „Wir schaffen } \\
\text { das”) } \\
\text { episztémé (értékalapú identitásépítés, } \\
\text { helyzetdefiniálás és vízióalkotás) } \\
\quad \text { (tranzaktiv vezetés > transzformativ } \\
\text { vezetés) }\end{array}$ & $\begin{array}{l}\text { praxisz (határozott és erélyes politikai } \\
\text { válaszok) } \\
\text { (karizmatikus vezetés) }\end{array}$ \\
\hline \multicolumn{3}{|c|}{ A ,helyes” kapcsolat } \\
\hline Hatalmi kapcsolat & $\begin{array}{c}\text { a hatalom kollektív gyakorlása (power } \\
\text { with) (követők aktív részvétele a } \\
\text { kihívások elérésében) } \\
\text { a hatalom mások feletti gyakorlása } \\
\text { (power over) (,als Bundeskanzlerin”; } \\
\text { „meine Aufgabe”; kívánt politikai cél } \\
\text { elérése ösztönzéssel és kikényszerítéssel) } \\
\text { (tranzaktiv vezetés > transzformativ } \\
\text { vezetés) }\end{array}$ & $\begin{array}{l}\text { a hatalom valaminek a megtételére } \\
\text { (power to) (populista és illiberális } \\
\text { demokratikus felhatalmazás,) } \\
\text { (karizmatikus vezetés) }\end{array}$ \\
\hline Interakciók iránya & $\begin{array}{l}\text { vertikális } \quad \text { (vezetés pozicionálás } \\
\text { megközelítése, érdekalapú kapcsolat) } \\
\text { (tranzaktivv vezetés) }\end{array}$ & $\begin{array}{l}\text { vertikális } \quad \text { (vezér szükségszerü } \\
\text { kiemelkedése, érzelmi kötődés) } \\
(\text { karizmatikus vezetés })\end{array}$ \\
\hline $\begin{array}{l}\text { A vezetők és a } \\
\text { követők szerepe }\end{array}$ & $\begin{array}{l}\text { reaktív (események követése) } \\
\text { koaktív (állampolgárok, menekültek és } \\
\text { EU tagállamok aktív részvételének } \\
\text { igénye a kihívások leküzdésében) } \\
\quad \text { (tranzaktív vezetés }>\text { transzformatív } \\
\text { vezetés) }\end{array}$ & $\begin{array}{l}\text { proaktív (történések kezdeményezése) } \\
\text { reaktív (nemzeti közösség és keresztény } \\
\text { kultúra megvédése) } \\
\qquad \text { (karizmatikus vezetés) }\end{array}$ \\
\hline
\end{tabular}

\section{Milyen kihívások előtt állt a vezetés? Milyen célokat tüztek ki a vezetők?}

A válság értelmezése során két eltérő kihívásként megjelenő helyzet rajzolódott ki. Orbán Viktor válságértelmezése a biztonságiasítás narratíváját követte, amely a közbiztonság, az életszínvonal és a keresztény és nemzeti kultúra védelmét, azaz a bizonytalanság leküzdését vonta maga után. A vezetői dramatizáció következményeként a migrációs válság azonban nem merült ki ennyiben, hiszen identitásválságot, elitválságot és demokráciaválságot is előidézett. Ezzel szemben Merkel elsősorban humanitárius krízisként kezelte a válságot, amelyet morális veszélyként a terrorizmus, a szélsőjobboldali mobilizáció és az európai szolidaritás hiánya tovább mélyíthet. Ennek nyomán fogant meg a morális alapítás gondolata és kihívása, amely a német és európai társadalom Willkommenskultur-ként való leírásában öltött testet. 
A vezetők válságértelmezésük nyomán eltérő célokat fogalmaztak meg. Orbán karizmatikus vezetésével a bizonytalanság leküzdésére vállalkozott. A keresztény Európa és a nemzeti közösség (ön)védelme lehetőséget adott Orbán számára, hogy régiúj rendet alakítson ki (Orbán-rezsim védelme, új migrációs politika) és az EU liberális értékekre alapozott normatív hatalmát megkérdőjelezze és rombolja. Az orbáni populista politika lényegében a vezetői alkalmasságát (őszinteségét, hitelességét és realitásértékét) volt hivatott alátámasztani. Ezzel szemben Merkel maga számára a transzformatív vezetésre jellemző morális alapítás kihívását fogalmazta meg. Ezt támogatta az a morális iránymutatás, amely a válság helyes értelmezésében és bizonyos végső értékek (a tolerancia, az igazságosság, a szabadság, a nyitottság és az együttérzés) védelmében és érvényesítésében mutatkozott meg. Ehhez kapcsolódott a követők felhatalmazásának az igénye és követelménye, amellyel elörevetítette a követők (állampolgárok és menekültek) aktív bevonását a kihívások leküzdésében. Mindazonáltal a követők transzformációja (nyílt társadalom, menekültek integrálása) a konstruktív problémamegoldás révén már alárendelődött egy a tranzaktív vezetésre jellemző közérdekre való hivatkozásnak, amely az integráció gazdasági és demográfiai lehetőségeit emelte ki.

\section{Milyen politikai tudást igényelt a célok elérése és a megfelelö eszközök kiválasztása?}

A taktikaalkotás és az eszközök kiválasztása során megmutatkozott a vezetők által a célok és kihívások függvényében demonstrálandó politikai tudás. Merkel taktikáját kettősség jellemezte: egyszerre kellett felmutatnia erős morális elköteleződést és felelősségvállalást, amely meghatározta a kihívások tekintetében vezetését, és pragmatista és feladat-orientált problémamegoldását. Ennek megfelelően a merkeli politika egyszerre igényelt egy ideológiai és filozófiai tudást (episztémé) és egy technikai (produktív) tudást (tekhné). Ez azt jelentette, hogy a német kancellár kemény hatalmi eszközökkel (szelektív ösztönzőkkel és jogi szankciókkal) és kompromisszumkészségével kívánta elérni morális céljait. Mindez a vízióalkotással szemben már egy tranzaktív vezetést láttatott. Az Orbán előtt lebegő a bizonytalanság leküzdésének, új rend kialakításának és alkalmassága bizonyításának kihívása már olyan határozott és erélyes politikai válaszokat és akciókat követelt meg, amelyekben tükröződnek a vezér politikai erényei és praktikus tudása (praxisz). Ennek megfelelően az orbáni taktikaalkotást az illegális bevándorlás hatásos kezelése és megállítása, valamint az európai liberális menekültpolitika semlegesítése határozta meg.

Miképpen értelmezhetö a vezetök és a követők hatalmi viszonya? 
A vezetők és követők kapcsolatát cselekvésüket összehangolva mindkét vezetés rendezte valamilyen módon. Ennek egyik kritikus eleme a hatalmi viszony megragadása volt. Merkel által elörevetített követők felhatalmazása egy kollektív módon gyakorolt hatalmat (power with) feltételez. Ez az ajánlat azonban csak szimbolikus maradt, hiszen Merkel céljait (pl. az integrációt és a regisztrációt) ösztönzéssel és kikényszerítéssel kívánta elérni és ezzel a hatalom mások feletti gyakorlását (power over) mutatta. Ezzel szemben Orbánt kihívás értelmezésének elfogadásával a követők hatalommal ruházták föl (power to), hogy megtegye azt, amit maguk nem tudnának véghez vinni.

\section{Milyen pályát írtak le a vezetök és a követők közötti interakciók?}

A hatalmi viszony meghatározza a vezetők és követők interakcióit. Mindkét vezető történetében vertikális kapcsolatot írt le. Ugyanakkor amíg Merkel számára ez a pozicionális vezetés értelmezéséből és az elsősorban érdekalapú kapcsolatból, addig Orbánnál a vezér szükségszerű kiemelkedéséből és a követők érzelmi elköteleződéséből adódott.

\section{Milyen szerepet kaptak a vezetök és a követők a vezetés folyamatában?}

Az identitásépítésből és a taktikaalkotás során kirajzolódtak a vezetőknek és a követőknek tulajdonított szerepek. Merkel számára a morális alapra helyezett nemzeti közösségén túl a menekültek és a EU tagállamok is a követök csoportját jelentették. Tőlük a kancellár különböző tartalommal, de kölcsönösen aktív részvételt várt el: az állampolgárok segítsék a menekültek befogadását, a menekültek illeszkedjenek be a német társadalomba és az EU tagállamok vegyenek részt a közös európai megoldásban. Mindazonáltal a kancellár csak reaktív módon követte az eseményeket. Ezzel szemben Orbán a követők közösségét leszűkíti a keresztény Magyarországra, Közép-Európára és Európára. Élesen leválasztotta közösségéröl a bevándorlókat és a politikai felelősöket (baloldali politikai elit, brüsszeli bürokraták, civil aktivisták, Soros György). Amíg a csoporton kívülieket a válság aktív előidézőiként határozta meg, addig a követők olyan reaktív és passzív szereplőkké váltak történetében, akiket a vezérnek meg kell (proaktív módon) védenie.

Összességében Merkel aligha vált teljesen transzformatív vezetővé (8. ábra) a válság során, hiszen a történetét domináló taktikaalkotást áthatotta a rá jellemző kompromisszumkész, pragmatista és feladat-orientált tranzaktív vezetés. S bár az ilyen jellegű morális elköteleződés egyáltalán nem volt jellemző Merkelre, mégis bizonyos mértékig valóban megközelítette a transzformatív vezetés ideáját. Ez a morális elköteleződés túlmutat a tranzaktív vezetésre jellemző eszközökhöz és intézményekhez 
kapcsolt modális értékeken, bár fontos aláhúzni, hogy Merkel ezen értékek forrását egy formális intézményben, a német alkotmányban határozta meg. Figyelemre méltó, hogy Merkel vállalta a politikai kockázatot, s kiállt ezen értékek mellett. Így, noha politikai pozíciója elbizonytalanodott a preferenciák alakulás nyomán, mégis sikerült a követőkkel kettős (érték- és érdekalapú) kötődést kialakítania azzal, hogy politikáját kompromisszumkereső módon a szigorítás irányába mozdította el, de nem adta fel morális elköteleződését. Merkel által felmutatott demokratikus vezetés megtalálta közönségét és sikerült politikájának főbb irányát megvédenie a vizsgált időszakban.

\section{8. ábra: Angela Merkel és Orbán Viktor vezetéskonstrukciói}

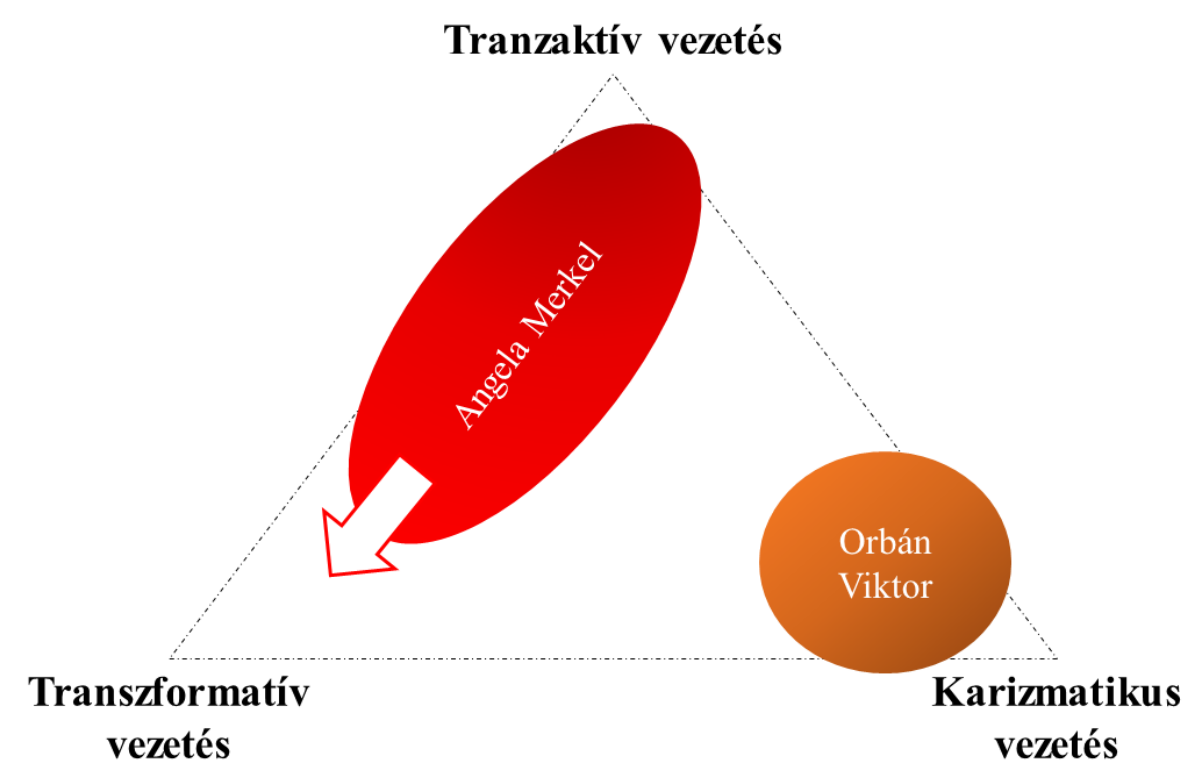

Orbán számára a válság lehetőséget kínált arra, hogy erősítse és megőrizze követőinek érzelmi elköteleződését és karizmájára vonatkozó percepcióit. Történetében folyamatosan dramatizálta a válságot, amellyel konstans módon erősítette azt az igényt, hogy vezetésének a kialakult bizonytalanság leküzdésére kell irányulnia. Ehhez sikerült bizonyítania alkalmasságát és egy „régi-új” rend kialakítására és védelmére tett erőfeszítéseit. Különösen érdemes megnézni Orbánnak a vezetésről és a demokráciáról megfogalmazott gondolatait, amelyek arra mutatnak rá, hogy ő a hatalmat az ország megvédéséhez, a közakarat érvényesítéséhez szükséges intézkedések megtételére kérte követőitől. Ezért szólt az orbáni történet elsősorban saját közönségének, s zárta ki azokat, akiktől nem várhatta el, hogy követőiként jelenjenek meg. Fontos azonban látni azt is, hogy az orbáni vezetés bizonyos elemei (EU és az idegenek szerepe, válság definiálása és kezelése) széles körben elnyerte a politikai közösség támogatását. Ez arra utalhat, hogy a magyar politikai kontextus kedvez a karizmatikus vezetésnek, amelyre végeredményben Orbán is ráismert. 


\section{9. AZ „IGAZÁN NEHÉZ NŐ” ÉS A „LELKES AMATŐR” Theresa May és Jeremy Corbyn vezetése a két Brexit választás között}

A Brexit népszavazás felszínre hozta azt a vezetés hiányt, amely már régóta mélyen áthatotta a brit politikát. Amíg egyes vezetők, mint David Cameron és Nigel Farage, kerülték a felelösségvállalást, addig más közegben, például a Munkáspártban, a vezetésben megjelenő problémákkal és nehézségekkel küszködtek. A vezetés hiánya nem hatékonysági kérdésként merült fel, azaz: ki az a politikus, aki képes képviselni az országot és végrehajtani a megszületett döntést a Brexit tárgyalások során. A népszavazás eredménye egyfajta morális (integrációs) pánikot teremtett, amely megkérdőjelezte a döntés (morális) helyességét. A vezetés hiánya tehát mélyebb és összetettebb problémának ígérkezett. Ebben a helyzetben a ,jó” vezetés (a kihívások értelmezése, a célok meghatározása és a megfelelő politikai tudás birtoklása) és a vezetők és követők közötti „helyes” kapcsolat (a hatalmi viszony, az interakciók iránya és a szerepelosztás) kérdése különösen kritikussá vált. A Brexit tehát nem csak a vezetés politikai kontextusát adta, de a demokratikus vezetés igényét és szükségszerüségét is kiemelte. A 2017-es előrehozott parlamenti választások e kérdések mentén folyt. Pontosabban, túl a felszínen megjelenő szakpolitikai kérdéseken Theresa May, mint egy „,igazán nehéz nő” („,bloody difficult woman” ${ }^{93}$ ) és a „lelkes amatőr” Jeremy Corbyn vetélkedése akörül folyt, hogy melyik vezető képes jó vezetést nyújtani és a követőkkel kialakítandó kapcsolatot helyesen rendezni. Az alábbi esettanulmányban e két vezető tevékenységét értelmezem a demokratikus vezetéstípusok fényében.

\subsection{Az eset kontextusa: a válság és a vezetők háttere}

A 2016. június 23-án tartott Brexit népszavazáson az Egyesült Királyság lakosságának 51,9\%-a az Európai Unióból való kilépés mellett döntött. A döntés bár klasszikus értelemben nem teremtett válságot, de több szempontból bizonytalanságot idézett elő az országban. Egyrészt a kilépés folyamata nehezen átlátható, interpretálható és nincsenek is pontos forgatókönyvek vagy precedensek arra, hogy miként léphet ki egy tagállam az

\footnotetext{
93 May úgy fogalmazott, hogy „,igazán nehéz nő” és tárgyalópartner (,bloody difficult women”) lesz a Brexit tárgyalások során (Asthana, Stewart, és Jennifer 2017).
} 
EU-ból. A Lisszaboni Szerződés 50. cikkelye mindössze öt bekezdésből áll és csupán azt határozza meg, hogy a tagállamoknak jogukban áll kilépni és a tárgyalásokat két éven belül le kell zárni.

Másrészt a „maradás-” és „kilépéspártiak” közötti törésvonal keresztbe metszette a két nagy párt közötti tradicionális, konzervatív-liberális és jobb-bal ellentétet (Prosser 2018, pp. 1-2; 8-9). A Konzervatív Pártot mélyen érintette a kérdés. A kormány és a képviselök többsége a maradás mellett állt ki, míg Boris Johnson és Michael Gove, a parlamenti képviselők egy jelentős kisebbségének az élén, a kilépés mellett kampányoltak. A Munkáspártot hasonlóan megbénította a kérdés. A munkáspárti körzetekben és demográfiai csoportokban (munkásosztály) a kilépés támogatottsága magas volt. Sőt, a párt vezetője Jeremy Corbyn, aki karrierje során végig kritikusa volt az EU-nak, vonakodva, de támogatta a maradást, de a kampányból érzékelhetően kivonta magát (Crines 2017b). Mindazonáltal azok többsége, akik a referendumot megelőzően a pártra szavaztak, a maradás mellett tették le a voksukat.

Harmadrészt a referendum rámutatott az ország idült vezetés hiányára is, amely individuális és kollektív szinten egyaránt jelentkezett (Bennister és Worthy 2016). ${ }^{94}$ Ebben a bizonytalan politikai szituációban az ország nem bővelkedett hosszan szolgáló pártvezetőkben, sőt a vezetők (pl. David Cameron és Nigel Farage) inkább kerülték a felelősségvállalást (Grint 2016). A vezetés igényét jelzi, hogy a 2017. június 8-án tartott előrehozott választások („Brexit választások”: Gifford 2017; Mellon és mtsai. 2018; Prosser 2018; vö. Jennings és Stoker 2017; Heath és Goodwin 2017) tétje a hiteles vezető és a megfelelő vezetés kiválasztása volt a kilépési folyamatok levezénylésére (Crines 2017a; Dorey 2017; Worthy és Bennister 2017). A politikai küzdelem két vezetőre, a konzervatív miniszterelnökre, Theresa Mayre és a Munkáspárt vezetőjére, Jeremy Corbynra hegyeződött ki, mind a kampányban (Deacon és mtsai. 2017; Dorey 2017), mind az eredményeket (Mellon és mtsai. 2018) illetően.

A két vezető nemcsak eltérő pályát futott be, de eltérő vezetést is testesített meg a Brexit időszakát megelőzően. A népszavazás következményeként lemondott hivataláról David Cameron miniszterelnök, amelyet követően hamar nyilvánvalóvá vált, hogy Theresa May követi őt pozíciójában. May több sikertelen választás után, 1997-ben nyert parlamenti mandátumot, majd 1999 és 2010 között számos portfoliót vállalt a konzervatív árnyékkormányokban. Míg 2010-ben Cameron belügyminiszternek nevezte

94 A probléma a Munkáspárt esetében sokkal mélyebbnek és régibbnek tűnik (ld. erről: Gaffney 2016; Shaw 2016). 
ki, amelynek feladatát 6 évig látta el, s így 1890 óta ő szolgált a leghosszabb ideig ebben a pozícióban. Ez idő alatt sikerült magáról egy karakteres vezetői képet kialakítania (Williams 2017). Határozott, kompetens és megbízható vezetőként jelent meg, aki a részletek mestere és kíméletlen, ha a helyzet úgy kívánja. „Biztos kezeivel” („safe pair of hands”: Goodlad 2017, p. 8) és pragmatizmusával megfelelt a bizonytalan politikai helyzet igényeinek. Ideológianélkülisége miatt egyenesen a „brit Angela Merkel” (Goodlad 2017, p. 9) megnevezéssel jellemezték. A pártpolitikát tekintve a modernizálást támogatta. 2002-ben a párt éves konferenciáján olyan „piszkos pártnak” (,,nasty party”: May 2002) titulálta saját pártját, amely nélkülözi a társadalmi alapot és szimpátiát. Egy reformista, „együttérző” politikát hirdetett, mellyel nyitni kíván a társadalom felé és egyúttal szakítani is a thatcheri örökséggel és - később a pártvezetői széket elfoglalva - a 2010 utáni megszorító politikával. A Brexit kampányban vonakodó maradáspárti politikusként támogatta Cameron álláspontját, de aktívan nem vett részt benne.

\section{YOUR CHOICE AT THIS ELECTION:}

\section{STRONG, STABLE} LEADERSHIP IN THE NATIONAL INTEREST
A COALITION OF CHAOS WITH JEREMY CORBYN
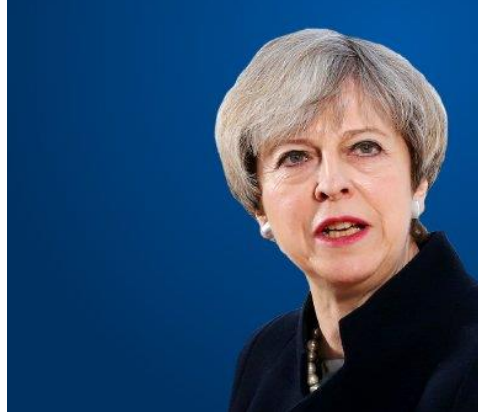

OR

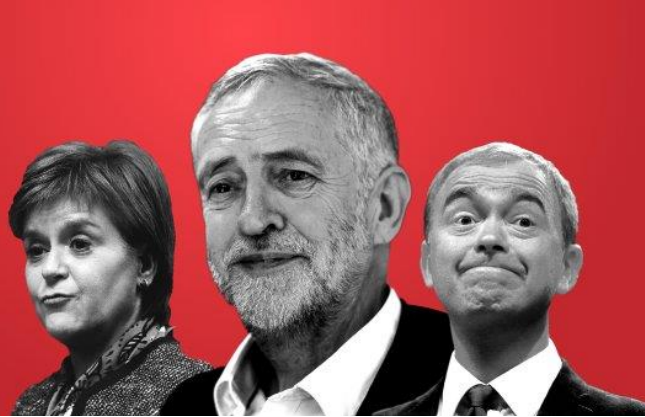

9. ábra: A 2017-es választások tétjét leiró Konzervativ kampányanyag (forrás: a párt twitter oldala)

Corbyn egészen más képet festett magáról. 1983-tól kezdődően backbencher képviselő volt, aki folyamatos „lázadásáról”, „mozgalmi aktivitásáról” volt ismert. Nem vállalt és nem is kereste a formális politikai pozíciókat. Ezért váratlan fordulat volt (Bennister, Worthy, és Keith 2017; Crines 2015; Diamond 2016), mikor 2015. szeptember 12-én döntő többséggel választották meg a Munkáspárt élére. Miután demokratizálásra került a pártvezető kiválasztása, a rendes párttagok, társult és regisztrált támogatók 59,5 százaléka voksolt rá, amely példátlanul erős mandátumot jelentett. Mindazonáltal a 232 munkáspárti képviselőből csupán 15-en támogatták, amely elörevetítette a személyét és 
politikáját övező, későbbiekben kiéleződő konfliktust. Corbyn politikájával tudatosan távolodik a politikai spektrum közepétől és tolódik baloldalra, kapcsolódva az Európaszerte erősödő megszorításellenes politikához és a párt klasszikus, kollektivizmust és társadalmi igazságosságot hangsúlyozó gondolatához. Szakítani kívánt Tony Blair harmadik utas, „New Labour” politikájával és központosító vezetési gyakorlatával. Corbynt az elemzők (Bennister, Worthy, és Keith 2017; Crines 2017b; Diamond 2016; Shaw 2016, 2017) „amatőr”, de hiteles politikusnak írják le, akinek imázsa közelebb áll az „alázatos szolgához”, mint egy „,gazi” vezetőhöz. S bár nem számít új politikai szereplőnek, ezzel a stílussal képes volt hitelesen „kívülállóként” megjelenni, amelyet csak tovább erősített a pártelit és a párttagság közötti konfliktus és az ellenséges médiakörnyezet.

\subsection{Az identitásépítés}

A Brexit népszavazást követően, amely csupán vékony többséget és megosztottságot eredményezett, szükségessé vált egy új többség, azaz a követők csoportjának a kialakítása. Bár mindkét ,vonakodó” maradáspárti politikus meg kívánta szólítani a kilépést támogatókat, mégis különbözőképp keretezték őket. May számára a követők csoportját a nemzet, az átlagemberek érdekközössége jelentette, akik proaktív módon döntöttek a Brexit mellett és így a Konzervatív pártnak ennek megfelelően (reaktív módon) kell politikáját alakítania. Corbyn viszont már az ország és az átlagemberek morális közösségéről beszél, akiknek koaktív módon kell részt venniük a problémák (migráció, Brexit) megoldásában. Ebben élen kell járnia a Munkáspártnak képviselve a munkásosztály értékeit, s így ki kell szorítania a politikából az olyan morálisan megkérdőjelezhető tényezőket, mint a rasszizmus vagy a xenofóbia.

Mindkét vezető története a munkából élő átlagember (,ordinary working people”) köré épült fel. Egyaránt benne találták meg a követök közösségének alapjait. Amíg May kormányfőként állandó szlogenné tette az „ország, amely mindenkiért müködik, s nem csak a kiváltságos kevesekért” („,country that works for everyone not just the privileged few”), addig Corbynnál a választási kampány során vált igazi hívószóvá a ,sokakért, és nem a kevesekért" (,for the many not the few”) fordulat. A többséget jelento" átlagemberek azok, akiket a westminsteri elit (Corbyn) és a globalizáció (May, Corbyn) hátrahagyott (,left behind”), és akik kiútként a Brexit mellett döntöttek. Ennélfogva ők lesznek a Brexit kedvezményezettjei. 
A hátrahagyottak narratívájával May a globalizáció egy patrióta kritikáját fogalmazza meg. Szembeállítja az átlagpolgárt a globalizáció haszonélvező, kozmopolita városi értelmiségével:

„[M]i egészen mást is értékelünk: az állampolgárság szellemét. Azt a szellemet, amely azt jelenti, hogy tiszteled a társadalmunkat megalapozó kötelékeket és kötelezettségeket. De ma, túl sok hatalomban lévő ember viselkedik úgy, mintha több közös lenne bennük a nemzetközi elitekkel, mint az utca emberével (...) De ha úgy hiszed, hogy te egy világpolgár vagy, akkor csak a semmi polgára [citizen of nowhere ${ }^{95}$ ] vagy. $\mathrm{S}$ egyáltalán nem érted mit jelent az állampolgárság fogalma.” (ford. tőlem) (May 2016e)

$\mathrm{S}$ bár mindkét vezető előszeretettel hivatkozik saját országára és nemzetére, mégis jól kivehető, hogy May a nemzet (nation, national) kifejezést vagy konkrét tulajdonneveket (UK, United Kingdom, Britain) részesíti előnyben, míg Corbynnál a neutrálisabb ország (country) megnevezés a hangsúlyosabb. ${ }^{96}$ May patriotizmusa azonban elsősorban a közös érdeken alapul, s nem valamifajta jól megfogható, körülhatárolható értéktartalommal bíró nemzeti identitáson.

Egyik vezető sem zárja le a közösség határait és nem keresnek külső ellenségképet. Mind az EU, mind Európa pozitív szerepet kapnak a vezetői történetekben. Amíg Corbyn esetében az európai külső szereplők értelmezése kevésbé hangsúlyos, addig Maynél kritikus, hogy Európát, az európai országokat közeli barátként és partnerként írja le. Az EU és tagállamai már nem ellenfelek, hanem tárgyalópartnerek, jelenlegi és jövőbeli szövetségesek. Így számára elengedhetetlen, hogy Európa is sikeres maradjon a jövőben.

Ezen túlmenően May a közösség sokszínűségét is hangsúlyozza, amely etnikai, felekezeti és társadalmi tekintetben is nyitott, befogadó (May 2016e). Az általa lefestett Nagy-Britannia mélyen internacionalista, (May 2017a) és osztja az európai liberális értékeket:

\footnotetext{
95 Megfogalmazásával tükrözi azt a szakirodalmi elválasztást (Jennings és Stoker 2017, pp. 4-5), amely különbséget tesz a lokális, nemzeti identitással rendelkezők („people from somewhere”) és az azzal nem rendelkező kozmopoliták (,people from anywhere”) csoportja között.

${ }^{96}$ Sokatmondó adat, hogy az ilyen jellegü utalások tekintetében Corbyn 37,6\%-ban, May 18,5\%-ban használta az „ország” (country) szót.
} 
„Fontos aláhúzni, hogy míg az Egyesült Királyság elhagyja az EU-t, mi mégsem hagyjuk el Európát, vagy vonulunk el a világtól. Britannia kifelé tekintő nemzet, a liberális, a szabadpiaci alapelvek és a demokratikus értékek erős hangja marad." (ford. tőlem) (May 2016c)

Corbyn számára egyértelmü kihívásként jelentkezett a Brexit döntés negatív morális hozadékának (Virdee és McGeever 2017) leküzdése. Szembenézett azzal, hogy a távozás mellett voksolókat a migráció kérdése erősen motiválta, amelyet ugyan fenntartásokkal kezel, de megérti az emberekben lévő feszültséget és kész szembenézni a problémával. ${ }^{97}$ Azonban aláhúzza, hogy a kilépésre szavazók többsége nem xenofób vagy rasszista indíttatásból döntött így. A kilépésre való szavazás csak egy válasz volt arra, hogy az átlagembert hátrahagyta a westminsteri elit (Corbyn 2016b). A rasszizmust és idegenellenességet nem a közösségnek, hanem a gyülöletbeszédet propagáló vezetőknek (Boris Johnson, Michael Gove, Nigel Farage) tulajdonítja. Ezzel egy olyan morális közösséget feltételez országában, amelyet meg kell védeni a rasszizmus minden formájától és nyitottabbá kell tenni a társadalmat: „,[h]a egyesítjük és vezetjük az országunkat, ennek kell lennie a legbefogadóbb és demokratikusan a legfelemelöbb [empowering] helynek, ahol a sokszínü közösségeink boldogulhatnak." (ford. tőlem) (Corbyn 2016b) Ennek érdekében egy emberi jogi nyelvet (,human rights language": Corbyn 2016b) ajánl, amely meggyőzőbb és megfelelőbb a migráció problémájának tárgyalására.

A vezetők egyaránt saját pártjuk mögé próbálták terelni a követők csoportját, amely kapcsán kritikussá vált az a kérdés, hogy ki értelmezi, képviseli és érvényesíti megfelelőbben az átlagember akaratát. Amíg a nemzeti érdekre való pozitív hivatkozás May esetében jellemző elemként jelenik meg, addig Corbyn elsősorban negatív keretben használja, rámutatva arra, hogy a konzervatív vezetés a pártérdekeket helyezi előtérbe és csak egy kiváltságos kisebbséget szolgál, míg pártja ezzel ellentétes politikát folytat:

„A Konzervatív Párt - a kiváltságosok, a leggazdagabbak pártja - áll a Munkáspárttal szemben; a párttal, ami kiáll a dolgozó emberekért, hogy javítsa mindannyiunk életét.” (ford. tőlem) (Corbyn 2017a)

\footnotetext{
97 „Hiszek abban, hogy a migráció gazdagítja az országunkat, a kultúránkat és a közösségünket. De azt is megértem, hogy a gyors változások feszültségeket és torzulásokat eredményezhetnek a közösségeinkben" (ford. tőlem) (Corbyn 2016c)
} 
S bár May esetében mind a saját pártjára, mind a Munkáspártra való utalás jelentősen kisebb gyakorisággal fordult elö, ${ }^{98}$ mint Corbyn esetében, mégis érdekes, hogy a Munkáspártot, ahogy korábban, 2002-ben saját pártját is, ,piszkosnak” titulálja:

„Tudjátok, hogy hívnak egyesek minket [a Konzervatív Pártot] - a piszkos párt. Tudom, hogy ez méltánytalan. (...) el kell érnünk társadalmunk minden részét. Azt akarom, hogy pártunk egész Britanniát képviselje, ne csak azt a mitikus helyet, melyet „Közép Angliának” hívnak.” (ford., kiemelés tőlem) (May 2002)

„Tudjátok, hogy hívják egyesek öket [a Munkáspártot]? A piszkos párt. A megosztott, megosztó és érinthetetlen Munkáspárt helyett kötelességünk van kiállni, képviselni, kormányozni az egész nemzetért. Így, ahol a Munkáspárt akadályokat épít, mi hidakat fogunk. Ez azt jelenti, hogy a méltánytalanságot és igazságtalanságot kezelnünk kell, és elő kell mozdítanunk az átlagos munkásosztálybéli ember helyzetét Britanniában" (ford., kiemelés tőlem) (May 2016e)

\subsection{A helyzetdefiniálás}

A vezetők a helyzet definiálásával igyekeznek megragadni a jelen kihívást jelentő állapotát. A referendum új politikai helyzetet teremtett, amely több szempontból is nehezen volt értelmezhető és interpretálható. Egyfelől a döntés jellegéből fakadóan a vezetőknek két valóságot kellett összekapcsolniuk. A választók közvetlenül hozhattak döntést az elszakadásról, de azt csak a tárgyalóasztal mellett, konvencionális módon lehet megvalósítani. Továbbá a helyzet a választók számára csak a jövőbeli eredmények fényében, az elszakadás következményeiben lesz érzékelhető. Így közvetlen tapasztalatuk a választóknak nem, vagy csak korlátozottan lehet a Brexittel kapcsolatban a kilépés folyamata során. Másfelől a vezetés is átmeneti állapotban találta magát. A vezető szemszögéből: már elindultunk valahonnan (Brexit döntés és a folyamat elindítása), de még nem érkeztünk meg (Brexit lezárása). A vezetés tehát e két pont között „félúton” van. A folyamat nyitott végü, amelyben a helyzetleírás (Hol vagyunk?) és a vízióalkotás (Hová tartunk?) végérvényesen összefolyik.

\footnotetext{
${ }^{98}$ Corbyn kevesebb releváns szövegben, de többször utalt saját pártjára (311-szer) és a Konzervatív Pártra (61-szer). Ehhez képest May csak 52-szer hivatkozott saját, és 15-ször a legnagyobb ellenzéki pártra. Ez persze indokolható a rendelkezésre álló szövegek típusával és a vezetők helyzetével is: míg Corbyn az ellenzék vezetője volt és a helyzete bizonytalan volt pártjában, addig May kormányfői pozícióban volt, és stabil támogatottságot élvezett a pártján belül.
} 
May és Corbyn egyaránt elfogadta a választói döntést, amelyet történelmet formáló momentumnak írtak le. A döntésben megfogalmazódott változásra való igényt May egyenesen „csendes forradalomnak" 99 írta le. A helyzetértékelésük is hasonlatos: a népszavazás bizonytalanságot szült, de lehetőséget is teremtett arra, hogy az ország problémáit orvosolják, és választ adjanak arra, hogy milyen országban kívánnak élni.

„Nemzetként nagy változás előtt állunk. Ahogy kilépünk az Európai Unióból, úgy kell meghatároznunk egy becsvágyó új szerepet magunknak a világban. Ez maga után vonja, hogy megkérdezzük magunkat, milyen országot akarunk: egy magabiztos, globális kereskedő nemzetet, amely továbbra is eljátssza a teljes szerepét a világ színpadán. De ugyanakkor úgy hiszem, hogy ez egy tökéletes lehetöség arra is, hogy hátralépjünk és feltegyünk néhány kérdést arról, hogy milyen országot akarunk otthonunkban.” (ford. tőlem) (May 2016a)

„Ez a választás nem magáról a Brexitről szól. Ezt az ügyet már rendeztük. A kérdés most az, hogy milyen Brexitet akarunk - és milyen országot akarunk a Brexit után? S kiben bízhatunk igazán, hogy a munkásembert helyezi az első helyre?" (ford. tőlem) (Corbyn 2017c)

Mindkét vezető igyekezett ennek fényében emelni a tétet, és rámutatni a helyzetben rejlő bizonytalanságra és annak leküzdésének szükségességére. May ${ }^{100}$ a kilépéssel járó bizonytalanság leküzdésére és a Brexit adta lehetőségekre helyezte a hangsúlyt. Ezzel a helyzetnek egy, a saját szemszögéből pozitív értelmet adott: a népszavazás a változás igényét fogalmazta meg, amely ugyan bizonytalanságot eredményezett, de lehetőséget is adott arra, hogy a kívánt változást elérjék. Ezzel szemben Corbyn, ellenzéki szerepéből adódóan, növekvő bizonytalanságot láttat, amelyet a kormány tevékenységének tulajdonít. Értelmezésében a kormány nem olvassa jól a helyzetet és a megfogalmazott változás igényét, de nincs is megfelelő terve annak végrehajtására.

Mindez azonban nem jelenti azt, hogy a vezetők a karizmatikus vezetést igénylő kihívásokat vázolnának föl. May a bizonytalanságot pragmatikus tranzaktív vezetésével („politikacsinálással’) kívánta felülírni. Értelmezésében a pártpolitikából származó instabilitás veszélyezteti a tárgyalásokat és a Brexitben rejlő lehetőségek kihasználását.

\footnotetext{
99 „De a változásnak be kell következnie, mert országunkban három hónappal ezelőtt csendes forradalom történt - egy forradalom, melyben polgártársaink milliói kiálltak és kifejezték: nem hajlandók tovább türni, hogy elhanyagolják őket.” (ford. tőlem) (May 2016e)

100 May devolúcióval kapcsolatos történetalkotását és vezetését lásd részletesebben: Árpási 2018, pp. 115-19
} 
A tárgyalási pozíció megerősítése (és a közérdek kialakítása) céljából kezdeményezte az elörehozott választások kiírását.

„Mert ez nem egy játék vagy a megfelelő idő arra, hogy pusztán az ellenzékiség kedvéért szemben álljunk. Ez egy kritikus és érzékeny tárgyalási folyamat, amely meg fogja határozni az országunk sikerét és érdekeit az elkövetkező évekre. S épp ezért létfontosságú, hogy megtartsuk a fegyelmünket." (ford. tőlem) (May 2017h)

„Az ország egyesült [a Brexit népszavazáson], de Westminster nem. (...) Westminsterben a megosztottság kockára teszi a képességünket arra, hogy sikerre vigyük a Brexitet és ez pusztító bizonytalanságot és instabilitást fog okozni az országnak. (ford. tőlem) (May 2017d)

Corbyn ugyan hasonlóképp kritizálja May „politikai játékát” a választások kírása kapcsán, mégis számára a helyzet morális téttel bír, s ezzel morális alapon is értékeli az eseményeket:

„Az elmúlt hét viharos eseményei után Britanniában - ideértve a múlt heti referendumon az Európai Unióból való kilépés megszavazását - nagyobb szükség van ránk, mint talán valaha, hogy ezen értékek [szolidaritás, társadalmi igazságosság, egyenlőség, internacionalizmus és emberi jogok] mentén egyesüljünk, hogy gyakoroljuk azt, amit hirdetünk, hogy a legmagasabb normák szerint ítéltessünk meg.” (ford. tőlem) (Corbyn 2016a)

A bizonytalanságnak tehát morális következményei lehetnek, amely a morális alapítás lehetőségének az elszalasztásában öltött testet.

\subsection{A vízióalkotás}

A helyzet bizonytalan jellegéből fakadóan felértékelődik a vezetői vízióalkotás is, amely során megfogalmazódnak és megformálódnak a kollektív célok. A két vezető eltérő célokat határozott meg, amelyből May tranzaktív vezetése és Corbyn transzformatív vezetése mutatkozott meg.

May pragmatista módon a „politikacsinálás” kihívásaként értelmezte a Brexit döntésből fakadó feladatokat, amely a közérdek kialakításában és a preferenciák újbóli kinyilvánításához szükséges politikai részvétel biztositásában öltött testet. A közérdeket a népszavazáson megfogalmazott döntés értelmezése jelentette. May számára a Brexitnek csak egyetlen olvasata van: „nincs kemény és puha Brexit közötti választás.” 
(ford. tőlem) (May 2016d) ${ }^{101}$ Máskor is ellentmondást nem türően fogalmaz May: „[é]ppen azért fogalmaztam úgy, hogy a Brexit Brexitet jelent [Brexit means Brexit], mert egyszerüen azt jelenti, és hogy igazán világos legyek: a brit emberek kívánságait fogjuk megvalósítani [deliver]” (ford. tőlem) (May 2016b). Később egy másik mottóként elhíresült fordulatával pontosítja álláspontját: „,[g]yakran mondom, hogy a »nincs alku az jobb, mint egy rossz alku« [no deal is better than a bad deal], mert ez Britannia nemzeti érdeke.” (ford. tőlem) (May 2017g). Ilyen értelemben May történetében Corbyn megalkuvó ${ }^{102}$, aki bármilyen áron, de alkut kötne az EU-val, míg Corbyn szemszögéből viszont May vakmerő hazárdőr, ha ragaszkodik a nincs alku politikájához. ${ }^{103}$

May a közérdeket két oldalról kívánta megfogni. Egyfelől May egy „új”, „bátor” és „magabiztos” szerepet vázolt fel a független és szuverén „Globális Nagy-Britannia” („Global Britan”) képében. Narratívájában a kilépéssel lehetőség nyílik arra, hogy újra globális szereplővé váljon az ország, előhívva a letünt birodalom romantikáját (Virdee és McGeever 2017, 4). Fontos kérdéssé válik a nemzetközi kapcsolatok, együttműködések megerősítése és újragondolásuk, különös tekintettel az Egyesült Államokra, a brit nemzetközösség államaira és a kilépést követően az EU-ra. Összességében a Globális Nagy-Britannia lehetővé teszi, hogy a szabad piacok, a szabadkereskedelem és a globalizáció mindenkit méltányosan szolgáljon. Ezzel megszelídíti azt a globalizációt, mely maga mögött hagyta az átlagembert. A kilépéssel az ország tehát lehetőséget kapott arra, hogy kezébe vegye sorsát és a globalizáció mozgatójává váljon.

Másfelől May történetében a Brexit lehetőséget teremt arra is, hogy az ország belső politikai, közösségi életét is újragondolják. A kilépéssel a britek megragadhatják a kontrollt, hogy a saját magukat érintő kérdésekben - mint például a migráció dönthessenek. May számára igen meghatározó motívum a kontroll visszaszerzése. Ilyen értelmezésben a népszavazás egyenesen visszaállította a brit parlamenti demokráciát és nemzeti önrendelkezést:

\footnotetext{
101 A két kategória a következőket takarja: amíg a „,kemény Brexittel” az országhatárok ellenőrzéséért feláldoznák a közös piaci hozzáférést, addig a „,puha Brexittel” elfogadnák a személyek szabad mozgását annak érdekében, hogy megtartsák ezt a hozzáférést.

102 ,Jeremy Corbyn úgy tünik azt gondolja, hogy bármilyen alku - függetlenül attól, hogy milyen áron, függetlenül attól, hogy milyen feltételekkel - jobb, mintha nem jutnánk megegyezésre.” (ford. tőlem) (May 2017g)

103 „Engedjétek meg, hogy tisztán fogalmazzak, a Miniszterelnök szerint a nincs alku jobb, mint a rossz alku, de a valóság az, hogy a nincs alku az egy rossz alku.” (ford. tőlem) (Corbyn 2017d)
} 
„Mi úgy látjuk, hogy ez [a népszavazás] egyértelmüen egy döntés volt arról, hogy visszaállítsuk a parlamentáris demokráciánkat és nemzeti önrendelkezésünket. Egy döntés volt arról, hogy átvegyük az irányítást és döntéseket hozzunk saját magunk számára” (ford. tőlem) (May 2017b)

A Brexit helyreállítja tehát azt a demokráciát, amely mindenkiért van (,,a democracy that works for everyone": May 2016e). May szerint olyan jó kormányzásra van szükség, amely az emberek javát szolgálja. Új többséget kívánt létrehozni a méltányosság értékének érvényesítése és az egyéni lehetőségek biztosítása mentén (May 2017c). Ebben vert gyökeret társadalompolitikai vízióként az úgynevezett „Nagy Meritokrácia” („Great Meritocracy”: May 2016a), amely a hátrahagyott átlagembert pozitív módon szólítja meg. Így, amíg a Globális Nagy-Britannia képes megvédeni és uralni a globalizációt, addig a Nagy Meritokrácia a társadalmi mobilitást kívánta felajánlani az átlagembernek. Mindezzel tudatosan új napirendet hirdetett egy modern konzervativizmusnak, amely „megérti a jót, amit kormány tehet” (ford. tőlem) (May 2016e).

Mindebből némiképp egy új rend kialakításának kihívása is kirajzolódhat, azonban azt felül írja May pragmatizmusa. Nemcsak nyíltan szakítani kívánt a nagy ideológiákkal, s így politikai értelemben középre tartani, de a víziók elé is helyezte saját cselekvését (May 2016e). Ehhez azonban stabil közérdeket megtestesítő választói döntésre volt szüksége, amelyet a népszavazáson megmutatkozó keskeny döntés képtelen volt megteremteni. Ezt a biztos alapot kívánta kialakítani a választások kiírásával, amely során erősebb mandátumot kért a választóktól:

„Csak mi [konzervatívok] nyújtunk tervet az erősebb Britanniához, egy még biztosabb jövőhöz. De csak ti tudtok megbízást [mandate] adni nekünk. Szavazzatok egy erősebb és stabilabb vezetésre ebben az országban! Szavazzatok arra az erős és stabil vezetésre, amelyre az országnak szüksége van! Adjatok megbízást [Give me the mandate] vezetni Britanniát! Adjatok megbízást tárgyalni Britanniáért! Adjatok megbízást harcolni Britanniáért és adjatok megbízást végrehajtani [deliver] [a Brexitet] Britanniáért!” (ford. tőlem) (May 2017f)

A választások során nem egy karizmatikus kapcsolat kialakítására és alkalmasságának bizonyítására tesz kísérletet, hanem az érdekalapú viszony megerősítésére és a Brexit technikai lebonyolítására kér mandátumot. 
Mindezzel szemben Corbyn történetében a Brexit népszavazás a morális alapítás igényét és lehetőségét teremtette meg. Erős ideológiai kötődése (Bennister, Worthy, és Keith 2017) nyomán története moralizálóvá vált és értékek mentén bontakozott ki, amelyben felsejlik a morális iránymutatásnak, a konstruktív problémamegoldásnak és a követök felhatalmazásának a mozzanata. Itt a Brexit népszavazás, May történetével szemben, önmagában nem a demokrácia megnyilvánulása volt, hanem egy segélykiáltás egy még demokratikusabb és igazságosabb politikáért és társadalomért. Corbyn a jelenlegi politikát látványsportként (,spectator sport”) írja le, amelyet csak pár ember üz Westminsterben, amelyben a politikusok fontosabbak, mint a közösség élete (Corbyn 2017b). Tehát a morális alapítás célja nemcsak nagyobb vagyon és jövedelemegyenlőség, amely az általa hangsúlyozott ,job-first Brexit” is megjelenít, hanem politikai (hatalmi) egyenlőség. Corbyn értelmezésében az állam és az állami szolgáltatások megerősítése mellett tehát szélesíteni kell a demokratikus részvételt is. Corbyn (2015) hivatalának elfoglalásakor egy „kedvesebb” (demokratikusabb) politikát (,kinder politics”) hirdetett, amely inkluzív, „bottom-up és nem top-down” (,,bottom up, not top down”: Corbyn 2015) és törődő társadalmat teremt meg. „Azon a kedvesebb, szelídebb politikán, amit tavaly nyáron, mikor a vezetés élére álltam, hirdettem, még mindig dolgozunk" (ford. tölem) (Corbyn 2016b)

Corbyn tehát olyan politikát vizionál, amely utat nyit az átlagember előtt a részvételhez és az érdekérvényesítéshez. Ennek eléréséhez szükséges a morális iránymutatása:

„Nos itt az ideje, hogy fordítsunk a dolgok állásán, hogy előtérbe helyezzük, központba állítsuk a munkásemberek érdekeit, hogy harcoljunk értékeinkért:

a társadalmi igazságosságért, a szolidaritásért, az egyenlőségért és az internacionalizmusért." (ford. tőlem) (Corbyn 2016d)

A „kedvesebb” (demokratikusabb) politikát kialakítani kívánó vezetése azonosul ezzel az iránymutatással: „Egyesek azonosítják a vezetést a »piszkossággal«. Nem értek velük egyet. A tisztesség nem zárja ki a vezetést - valójában annak előfeltétele kell, hogy legyen." (ford. tölem) (Corbyn 2016b). Corbyn szemében a Munkáspártnak ebben kritikus szerepe van: tisztességgel és értékeihez hüen kell vezetnie, különösen akkor, amikor a Konzervatív Párt képtelen erre.

A morális alapítás gondolata nem nélkülözi a követők felhatalmazásának a célját sem. Ezen az alapon utasítja el Corbyn a May által felkínált vezetési stílust: „Amíg a bizonytalan vezetők még több hatalmat kérnek, hogy erősebbnek érezzék magukat, addig én az erős vezetést abból ismerem meg, hogy több hatalommal ruház fel titeket." 
(ford. tőlem) (Corbyn 2017e) Vezetőként tehát meg kell osztania a hatalmát: „,[m]indig hittem abban, hogy szilárdan kell állni és felhatalmazni [empowering] másokat arra, hogy elhatározzák magukat és felszálljanak a fedélzetre, ha készek.” (ford. tőlem) (Corbyn 2017e)

A corbyni konstruktív problémamegoldás és konfliktuskezelés egy deliberatív politikai folyamat támogatását jelentette, amelynek központi eleme a vitára való nyitottság és a diskurzus kitágítása, zavaró tényezők kiszürése. „[A] vezetés feladata, hogy a teret nyitva tartsa a nézeteltéréseknek, új gondolatoknak és a célnak megfelelő politikának" (ford. tőlem) (Corbyn 2017e) Értelmezésében racionális és nyugodt eszmecserére van szükség, hogy egy új egységet és konszenzust hozzanak létre. S ezt a vitát a Munkáspártnak kell vezetnie (Corbyn 2016c). A felkínált diskurzusból egyedül a rasszizmust zárja ki kategorikusan, amely ellen univerzális értékekkel kell harcba szállni és érvényesíteni az átlagember érdekét (Corbyn 2016b). Ezt a politikát szimbolizálta az, hogy amíg May elutasította a televíziós vitán való részvételt, addig Corbyn vállalta a szereplést, amelyen végül Amber Rudd helyettesítette a konzervatív pártvezetőt 2017. május 31-én. Söt ezt a képet erösítette az is, hogy amíg May távolságtartó mentalitása és „robotikus” kommunikációs stílusa ${ }^{104}$ miatt nehezen teremtett kapcsolatot közönségével, addig Corbyn spontán, közvetlenül, és hiteles módon tudott kommunikálni követőivel.

\subsection{A taktikaalkotás}

A két Brexit szavazás közötti időszak (8. táblázat) a vezetőket rákényszerítette saját politikai pozíciójuk megerősítésére, amelyhez a rendelkezésre álló erőforrásokat kívánták kihasználni. A víziójuk eléréséhez alkalmazott eszközöknek demonstrálniuk kellett politikai tudásukat. Emellett komoly feladatot jelentett az is, hogy a követőkhöz való kapcsolódást (hatalmi viszonyt, interakciókat és szerepelosztást) rendezzék. A Brexitről a döntést közvetlenül az állampolgárok hozták meg, annak érvényesítését viszont már a vezetők csak zárt tárgyalásokon érhették el. Így a vezetők és követők közötti távolság óhatatlanul megnőtt, amelyet a taktikaalkotás során minimalizálni kellett.

May taktikaalkotását ellentmondások bénították meg, amelyek abból fakadtak, hogy a tranzaktív vezetésén túlmenő változásnak az ígérete fogalmazódott meg politikájában. May feladatértelmezése egyenes pályát ír le: a Brexit népszavazáson született választói

\footnotetext{
${ }^{104}$ Sokatmondó, hogy Mayt kommunikációs stílusa miatt pejoratív módon a közbeszédben egy robothoz hasonlították (Maybot: Bale és Webb 2017, p. 21).
} 
akaratot („Brexit means Brexit”) végre kell hajtani. Vezetőként nem tehet hát mást, mint egy szolgáltató: „teljesíti” és „,kézbesíti” (deliver) a választói akaratot kielégítő politikát és a Brexitet, mint egy terméket, azaz a legjobb egyezséget a kilépési tárgyalások (,,no deal is better than a bad deal”, „,bloody difficult woman”) során. Ehhez erős, igazolt és biztos vezetésre van szükség, amely - May értelmezésében - egy:

„[k]épesség arra, hogy a dolgokat bátran kimondjuk és a nehéz feladatokat elvégezzük. Szembenézni a kihívásokkal és megoldani azokat, s nem pedig úgy tenni, mintha nem léteznének; vagy azt kívánni, hogy azok eltünjenek maguktól. Erő, hogy egyenesen viselkedjünk az emberekkel és ne csak azt mondjuk nekik, amit hallani akarnak. Képesség, hogy a feladatot elvégezzük. Ez jelenti számomra a vezetést. $\mathrm{S}$ ez az a vezetés, amit a brit népnek ajánlok ezen a választáson.” (ford. tőlem) (May 2017g)

8. táblázat: Theresa May és Jeremy Corbyn vezetésének idővonala a két Brexit választás között.

\begin{tabular}{|c|c|}
\hline 2016. június 23. & Brexit népszavazás. \\
\hline \multirow[t]{2}{*}{ június 24.} & David Cameron lemond a miniszterelnöki posztról. \\
\hline & Jeremy Corbyn elfogadja a népszavazás eredményét. \\
\hline június 26-27. & Lemondási hullám Jeremy Corbyn árnyékkormányában. \\
\hline június 28. & $\begin{array}{l}\text { A Munkáspárt jelentős többsége elfogadja a Corbyn ellen benyújtott } \\
\text { bizalmatlansági indítványt. A döntést Corbyn nem fogadja el, s nem mond } \\
\text { le. }\end{array}$ \\
\hline június 30. & Theresa May hivatalosan is bejelenti, hogy indul a pártvezetői pozícióért. \\
\hline július 11. & $\begin{array}{l}\text { May megszerzi a képviselőcsoport többségének támogatását. Miután } \\
\text { lemond legföbb kihívója, Andrea Leadsom, hivatalosan is ő lesz a párt } \\
\text { vezetője. }\end{array}$ \\
\hline július 12. & Hivatalosan is elindul a Munkáspárton belül a kampány a pártvezetésért. \\
\hline július 13. & Mayt kinevezik miniszterelnöknek. \\
\hline július 19. & $\begin{array}{l}\text { Angela Eagle visszalépésével és támogatásával a Munkáspárt mérsékelt } \\
\text { szárnya képviseletében Owen Smith lesz Corbyn egyedüli kihívója. }\end{array}$ \\
\hline szeptember 24. & Corbynt pártvezetőként újraválasztják. \\
\hline október 5. & May a Konzervatív Párt éves kongresszusán ismerteti vízióját. \\
\hline 2017. január 17. & May Brexit beszédében felvázolja a kilépéssel kapcsolatos terveit. \\
\hline március 22. & Első londoni terrortámadás 2017-ben. \\
\hline március 29. & May élesíti az 50. cikkelyt a Donald Tuskhoz írt levelével. \\
\hline március 30. & Kiadják a kilépésről szóló Fehér könyvet. \\
\hline április 18-19. & $\begin{array}{l}\text { May előrehozott választást kezdeményez, amelyet másnap az alsóház, } \\
\text { többek között munkáspárti támogatással jóváhagy. }\end{array}$ \\
\hline május 3. & Formálisan feloszlatják a parlamentet és hivatalosan is elindul a kampány. \\
\hline május 16. & Corbyn bemutatja pártjának programját. \\
\hline május 18. & May bemutatja pártjának programját. \\
\hline május 22. & Manchesteri terrortámadás. \\
\hline május 31. & $\begin{array}{l}\text { Televíziós vitán May helyett Amber Rudd áll ki Corbynnal és a többi párt } \\
\text { vezetőjével szemben. }\end{array}$ \\
\hline június 3. & Második londoni terrortámadás 2017-ben. \\
\hline június 8. & $\begin{array}{l}\text { Parlamenti választások. May győz, de elveszti abszolút többségét. Corbyn } \\
\text { jelentősen növeli pártja parlamenti mandátumainak számát. }\end{array}$ \\
\hline június 11. & May kisebbségi kormányt alakít. \\
\hline
\end{tabular}


Az általa kezdeményezett előrehozott választáson tehát May bizalmat kért a kormányzás és a kormány számára, amely „képes jót cselekedni” azzal, hogy kiszolgálja a közérdeket, illetve azt a gyakorlatba ülteti. A végrehajtásra kihegyezett vezetés kemény hatalmi eszközök és szelektív ösztönzők használatát és egy termék (Brexit) legyártását és leszállítását vetíti előre. Mindez egy technikai és produktív tudás (tekhné) meglétét feltételezi, amellyel may nem karizmatikus vezetőként teremteni (praxisz) kívánt, hanem egyszerüen csak végrehajtani.

A mayi történetében a proaktív követők kinyilvánítják véleményüket a Brexittel kapcsolatban meghatározva ezzel a közérdeket, amelyet a vezető víziójával tartalommal tölt fel, és amelynek érvényesítésére mandátumot kér („Give me the mandate to”) a választóktól. Ez a mandátum igénylés egyfajta felhatalmazást (power to) rejt magában, ez azonban nem realizálódik - egy új rend kialakításának és a régi lerombolásának hiánya okán - a kihívásértelmezésében, a követők szerepének meghatározásában és a megfelelő politikai tudás (alkalmasság) demonstrálásában. Mindezzel így May csupán formális pozícióját kívánja megerősíteni, amely biztosítja számára a kellő hatalmi eszközöket és a szükséges hatalmat, amelyet ily módon mások felett gyakorol (power over). A felrajzolt interakciók iránya vertikális, azaz egyfajta alá-fölérendeltségen alapulnak. Ez semmiképpen sem jelenthet érzelmi (karizmatikus) kötődést a követőhöz, pusztán egy érdekalapú kapcsolatot.

Ezt a képet erősíti May énközpontú vezetésfelfogása. Üzenete határozott: „én, mint miniszterelnök és pártvezető, vezetek”, „én vagyok egyedül a felelős az ország vezetéséért”, „én rendelkezem egyedül a kellő tudással, eszközökkel és helyes vízióval".

„Tehát ajánlom magamat Miniszterelnökként még egyszer, azzal a határozott elköteleződéssel, hogy folytassam a Brexit végrehajtásának [delivering] munkáját; olyan magabiztossággal, amellyel mindenki számára kedvező [works for all] megállapodást érhetek el; és azzal a hittel, hogy van vízióm, tervem, akaratom és tapasztalatom beteljesíteni a Brexit ígéretét; és építeni egy jobb Britanniát.” (ford. tőlem) (May 2017g)

De ezt a megközelítést testesítik meg az olyan fordulatok is, mint „,a kormány, amelyet én vezetek” („Government I lead”), ,az én vezetésem alatt” (,under my leadership”), de a fenti idézet is árulkodó lehet: „a vezetés, amelyet én ajánlok” (,leadership that I offer'). 
Ebböl a szemszögből kritikus ponttá válik az ellenfél inkompetenségére való rámutatás. May értelmezésében Corbyn lényegében feladja a vezetést, lemond róla: „Ez nem vezetés, hanem lemondás a vezetésröl” (ford. tőlem) (May 2017g) S bár Corbyn képes vezetni egy tiltakozást, de képtelen egy országot (,He can lead a protest; I am leading a country": May 2017e). Összességében ebben a képben a munkáspárti vezető csak gyenge és bizonytalan koalíciós vezetésre képes, amely csak káoszt hozhat.

Az ellentmondások legjobban abban mutatkoztak meg, hogy egyszerre kíván magának reaktiv és proaktiv szerepet felvázolni. May által bemutatott (tranzaktív) vezetés egy reaktív szerepet vetített előre, amely kompromisszumot teremtve követi a preferenciák alakulását és nem proaktív módon formálja azokat. Miniszterelnöknek való választása magában hordozta a kompromisszum lehetőségét. Képes volt egységet kínálni pártjának, akiket megosztott a népszavazás kérdése. Kivívta a parlamenti képviselők jelentős többségének a támogatását, amely a párt vezetőválasztásának demokratizálása óta (1965) a legerősebb mandátumot biztosította számára (Jeffery és mtsai. 2017). Jeffery és munkatársai (2017) rámutattak arra, hogy megválasztásában központi szerepet játszott Maynek a Brexit kérdésében történő irányváltása. A kormányalakítás, mely az egyik legmélyebb átalakításnak bizonyult a háború utáni Nagy-Britanniában (Allen 2017), is erre az elvre épült. Kulcspozíciókba helyezett kilépéspárti politikusokat: Boris Johnson külügyminiszter, David Davis kilépést felügyelő miniszter, míg Liam Fox a nemzetközi kereskedelemért felelős miniszter lett. Azonban maradáspárti politikusoknak - akik jelentős többségben foglaltak helyet a kabinetben is fontos pozíciókat osztott: Philip Hammondot pénzügyminiszterré, míg Amber Ruddot belügyminiszterré nevezte ki. Ezzel részben meg kívánta osztani a felelősséget és át is kívánta hidalni a konfliktusokat. A szélesebb kompromisszum kialakítása azonban proaktív lépéseinek köszönhetően meghiúsult, amelynek egyik s talán legfontosabb oka a zárt, csak a belső tanácsadókat bevonó döntéshozatal (groupthink: Dunleavy 2017; Goodlad 2017) volt.

A proaktív szerepvállalás megmutatkozott abban, ahogyan a Brexit kérdéséhez viszonyult. A Brexit népszavazást megelőzően támogatta Cameron maradáspárti pozícióját, amelyet a népszavazást követően felváltott egy erős kilépéspárti retorikával. Ez azonban túlmutatott egy lehetséges kompromisszum kialakításán. A Brexit kemény értelmezésével (,, Brexit means Brexit”, „, no deal is better than a bad deal”, „bloody difficult woman") láthatóan kereste a konfliktust, amellyel egy új többség kialakításának proaktív (karizmatikus) módját jelenítette meg. Erről árulkodott az is, hogy a 
pozicionálás szerepértelmezést is kitágítja, és proaktív cselevést ír elő: „A kormány a cselekvésröl szól. Arról szól, hogy teszünk valamit, s nem arról, hogy vagyunk valakik.” (ford. tőlem) (May 2016e)

Mindehhez azonban nem társult a karizmatikus vezetésre jellemző, egy új rend kialakítására tett meggyőző ígéret és kísérlet, az alkalmasság bizonyítása, gyakorlati tudás (praxisz) felajánlása és érzelmi kötődésen alapuló felhatalmazás (power to). Ugyancsak hiányzik a közösségen kívül eső szereplök (EU, maradáspártiak) démonizálása és a megvédendő követők reaktív szerepbe szorulása. Az alkalmasság és a gyakorlati tudás hiánya is kiütközött bizonyos kérdésekben megjelenő bizonytalanságában. Például sokáig kizártnak tartotta az előrehozott választások kírását, amelyet azonban 2017. április 18-án végül váratlanul meglépett. Sőt, ezen túlmenően a szakpolitikában (például a rókavadászat és a „demencia-adó” kérdésében) megmutatkozó irányváltások még a közérdek kialakításának kihívását tekintve is megrendítették May vezetését.

Összességében May vezetésében megmutatkozó ellentmondás megkérdőjelezte hitelességét. A proaktív magatartás ellentétbe kerül a tranzaktív vezetéssel azáltal, hogy aláásta a közérdek reaktív kialakítására tett erőfeszítéseket és így a követőkkel kialakítandó kapcsolatot. May által leírt politikai folyamatban nem lehet egyszerre a vezető és a követők csoportja is proaktív. S ebből a szemszögből az előrehozott választások sem a preferenciák kinyilvánítását jelentő politikai részvételt hívta elő, hanem csupán a bizonytalanság erősödését. May egyszerüen többre vállalkozott, mint amit elvártak tőle vagy épp, amire ő maga megteremtette volna az igényt.

A miniszterelnökkel szemben Corbyn képes volt taktikájának alakításával és performatív cselekvésével hiteles (ellentmondásokat nélkülöző) vezetést felmutatnia. Ennek egyik alapja morális karaktere (Bennister, Worthy, és Keith 2017; Crines 2017a) volt, amely megmutatkozott üzeneteiben és a megtestesített morális alapítás gondolatában és iránymutatásban. Személyét szorosan a párthoz és a párt által megfogalmazott értékekhez kötötte, amelyet csak ő képes tisztán, hitelesen képviselni és így a Brexitet az átlagember javára fordítani. Ironikus módon annak ellenére alakult ki körülötte személyi kultusz, hogy a személy-centrikus politikát többször is elutasította (Bennister, Worthy, és Keith 2017). Ez a személyi kultusz azonban nem egy nemzetét megmentő hősről, hanem egy morális vezetőről szólt, aki - ahogy arra egyes elemzők rámutattak (Shaw 2017) - a weberi érzületetika mentén építette fel politikáját. Politikai 
vezetése morális kötelességként jelent meg, amelynek teljesítéséhez képes volt ideológiai (elméleti, filozófiai) tudást (episztémé) felmutatni.

Hitelességének másik alapja abban mutatkozott meg, hogy az általa felmutatott mozgalmi politikában és aktivista attitüdben visszatükröződtek vízióinak azon elemei, amelyek a követők felhatalmazásának és a konstruktív problémamegoldásnak a szükségességére mutattak rá. Ebben a (kedvesebb) politikában megvalósulni látszott a hatalom kollektív gyakorlásának (power with) ideája, a vezetők és követők horizontális interakciói és koaktív szerepvállalásuk. Mindezzel - May vezetésével szemben rendeződni látszik Corbyn követőkkel való kapcsolata.

Ez a fajta politika nem csak alkalmasnak bizonyult a politikai túlélésre, amely Corbyn legfőbb prioritása volt, de még jobban meg is erősítette pozícióját. A Brexit referendum és a sikertelen kampány nyomán felerősödtek pártjában a személyét érintő kritikák: 2016. június 25-én bizalmatlansági indítványt nyújtottak be ellene képviselőtársai, majd a 26-27-i lemondási hullámot követően a 31 árnyékkormánytagból csupán 8 maradt a helyén, végül 28-án a frakció 172:40 arányban meg is vonta tőle a támogatását. A pártvezető nem fogadta el a döntést és nem mondott le, a párttagságtól kapott mandátumára hivatkozva:

„A Munkáspárt tagjainak és támogatóinak a 60\%-a demokratikusan választott meg engem pártunk vezetőjének egy újfajta politikára, és nem fogom őket elárulni azzal, hogy lemondok. A képviselők mai szavazásának nincs [párt] alkotmányos legitimitása. Mi egy demokratikus párt vagyunk egy tiszta alkotmánnyal. A mi népünknek szüksége van arra, hogy a Munkáspárt tagjai, szakszervezeti tagok és képviselök egyesüljenek a vezetésem mögött ebben a kritikus időben a mi országunkért." (ford. tőlem) (Corbyn 2016e)

Végül július 12-én hivatalosan is elkezdődött a párvezetésért folyó kampány. A választás arra volt kihegyezve, hogy milyen típusú pártot kívánnak a jövőben: „parlamenti pártot”, ahogy a mérsékelt szárnyat képviselő kihívó Owen Smith elörevetítette, vagy egy, a Corbyn-féle „mozgalmi pártot” (Crines 2017b, p. 27). Szeptember 24-én azonban döntő többséggel, 61,8\%-al újraválasztotta a tagság, kismértékben javítva korábbi támogatottságát (59,5\%). A győzelem és az erős mandátum Corbyn számára több szempontból is szimbolikus jelentőséggel bírt. Egyfelől szimbolizálta vezetői karakterének hitelességét, amely elitellenességéből, kívülállóságából és a párthoz és értékeihez való hüségéböl fakadt. Így kihívói nemcsak 
vele, hanem a párt érdekével, értékeivel és az „új”, demokratikusabb politikával is szembefordultak, mikor megkérdőjelezték vezetését. Az állandó támadás és nyomás csak szilárdabbá tette pozícióját. Másfelől mindez még elhivatottabbá tette a párt átalakítására tett elköteleződésében. Az általa hirdetett új és „kedvesebb” politikát előbb pártján belül kívánta érvényesíteni, amely így képes lesz megfelelően vezetni az országot.

Ezt a politikát mozgalmi dinamika, állandó kampány, mobilizáció és tiltakozás jellemzi. Ennek középpontjában a Momentum mozgalom áll, amely személye köré szerveződött és több mint 23.000 fös tagsággal és 150 helyi csoporttal behálózta az országot. A mozgalom mellett Corbyn a párttagságra is erősen támaszkodhatott, amely nagymértékben megnövekedett a 2015-ös parlamenti választásokat követően. S bár 2010-ben már elindult a tagság bővülése, akkor megközelítőleg 190.000 főt számlált a párttagság. Ez a szám 2015 végére 388.000, 2017 júniusában már 552.000 fő volt. ${ }^{105}$ Ezt egészítették ki a szakszervezetekből érkező társult- és a pénzdíj ellenében regisztrált támogatók. A 2015-ös pártelnöki választásokon összesen 422.664 fő voksolt, amelyből 245.520 rendes párttag, 105.598 regisztrált és 71.546 társult tag szavazott. A 2016-os választásokon a részvétel megnövekedett: 506.438 szavazóból 285.176 rendes tag, 121.527 regisztrált és 99.745 társult támogató volt. ${ }^{106}$

Corbyn számára tehát rendelkezésre állt egy igen erős kampánygépezet, amelyet ugyan a Brexit népszavazáson, és a helyi- és közigazgatási választásokon nem tudott kihasználni, de a 2017-es parlamenti választásokon már döntő jelentőségűnek bizonyult (Bale és Webb 2017). Ezen a gépezeten nyugodott a sikeres grassroots mozgósítás és a fiatalabb generációkat megszólító online kampány (Chadwick 2017). Az ellenséges médiakörnyezet (Banaji 2017; Cammaerts és mtsai. 2016; Deacon és mtsai. 2017), melyben Corbyn személye és üzenetei torzítva és negatív hangvétellel jelentek meg, csak erősítette az ,igaz” ellenállás mítoszát. A mozgalomnak sikerült egy alternatív médiateret biztosítania a fiatal baloldaliaknak, ahol a támogató jellegü politikai vélemények kifejezése az igazság kimondásának érzetét keltette a média fóáramával és az elittel szemben. Így az ellenállás misztifikálódott és állandósult. Túl a specifikus szakpolitikai ígéreteken (tandíj eltörlése és minimálbér-emelés) a fiatal szavazók számára igazán vonzó volt Corbyn nyitott és még demokratikusabb politikája (Henn és

105 Összehasonlításképp: a Konzervatív Párt a legutóbb (2013-ban) közreadott információi szerint megközelítőleg 150.000 fős párttagsággal rendelkezett (Keen és Jackson 2018).

${ }^{106}$ A számadatokról lásd bővebben: Keen és Jackson 2018 
Hart 2017; Norris 2017). Ennek eredménye az lett, hogy a fiatal szavazók jelentős többségét sikerült megszólítania a kampányban (YouGov 2017c).

\subsection{A követők mobilizálása}

A vezetők meg kívánják győzni potenciális követőiket történetük és vezetésük helyességéről. A két vezető történetében egészen más hangsúlyt kapott a Brexit kérdése. A követők mobilizálását két tényezőben ragadtam meg: a vezetők hatásgyakorlásában és az állampolgári preferenciák alakulásában.

A hatásgyakorlás vizsgálatakor elöször a Brexit szempontjából releváns szövegek arányát vettem szemügyre az összes vezetői megnyilatkozáshoz viszonyítva (6. ábra). A vizsgált időszakban May megnyilatkozásai 51\%-ban, Corbyn megnyilatkozásai viszont csak 31\%-ban voltak relevánsak. Ezen szövegek havi eloszlása a 2. ábrán követhető végig. S bár May nagyobb figyelmet szentelt a kérdés tárgyalására, mégis a hangsúly kiegyenlítődni látszik a vizsgált időszak végére. Másodszor a téma súlyát elemeztem a releváns szövegeken belül. Ebben a tekintetben is nagy különbség volt érezhető a két vezető között. Ugyanis ez az arány átlagosan 37\% volt Maynél, 44\% Corbinnál, ami arra utal, hogy a munkáspárti vezető egy-egy megnyilatkozásában jobban részletezte történetét, mint ellenfele. Jól láthatóvá vált, hogy a kérdés tárgyalásának súlya Corbynnál 2016 novemberétől kezdett nőni. Mind az arányokat, mind a tartalmát tekintve Corbyn érezhetően nehezen birkózik meg a Brexit morális megítélésével és univerzális értékekhez való kapcsolásával, amelyre 2016 végétől kezdve, de főképp 2017 februárjától sikerült valamilyen megoldást találnia és így saját vezetői történetébe helyezni a kérdést.

10. ábra: A releváns beszédek aránya 2016. július és 2017. május között

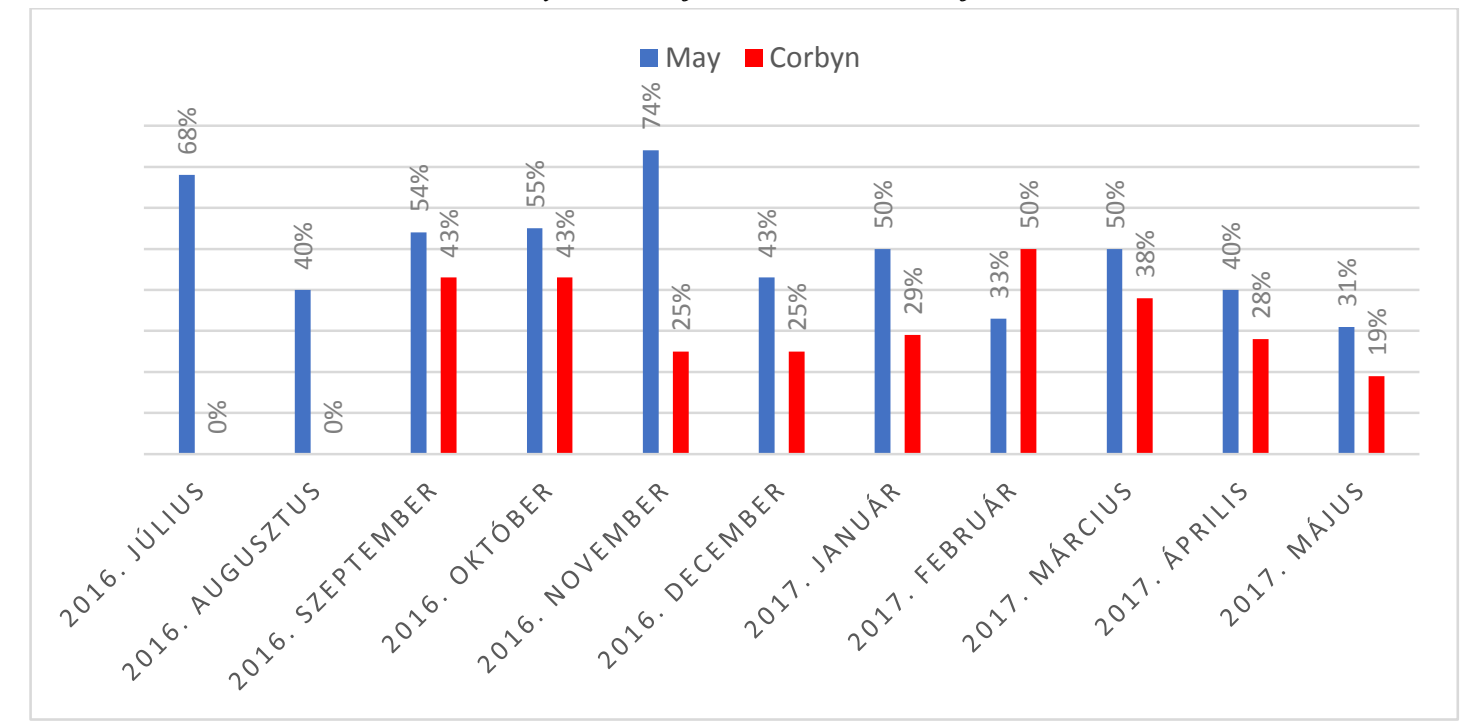

Forrás: saját gyüjtés 
Rátérve az állampolgárok preferenciáinak változására, fontos aláhúzni, hogy a választásokon lényegében a választók két vezető „Brexitről” szóló történetét és az ahhoz kapcsolt vezetést értékelték. A választást annak ellenére a Brexit uralta (Mellon és mtsai. 2018; Prosser 2018; vö. Jennings és Stoker 2017; Heath és Goodwin 2017), hogy az a kampány alatt relatíve kis hangsúlyt kapott (Deacon és mtsai. 2017). Mindazonáltal a választók döntő hányada (33\%) is az ország legfontosabb ügyének ítélte meg, amelyről úgy gondolták, hogy meghatározta döntésüket a szavazást illetően (YouGov 2017b). A választások mindkét vezető számára kritikus volt. Amíg May még nem mérettette meg magát jelentősebb vezetői kampányban, addig Corbyn számára a cél a politikai túlélés volt. Mindkét vezető közvetlen követői között érezte igazán „otthonosan” magát, így összességében a megmérettetés mindkét vezető számára az volt, hogy miképpen tudják saját történetüket eladni egy szélesebb közönség számára. Összességében May döntése az elörehozott választások megtartásáról racionálisnak tünt. Ugyanis abban az időszakban May népszerübb volt pártjánál, továbbá a Konzervatív Párt 23\%-kal előzte meg a Munkáspártot a pártot választani tudó, biztos szavazók körében, sőt a válaszadók 54\%-a gondolta úgy, hogy May alkalmasabb miniszterelnöknek, mint Corbyn, akiről 15\% vélekedett így (YouGov 2017d).

A kampány során azonban jelentősen megváltozott a pártok és a vezetők támogatottsága. Mind a pártok támogatottságában (11. ábra), mind a vezetők alkalmasságát (12. ábra) és elfogadottságát (13-14. ábra) tekintve arra lehetünk figyelmesek, hogy amíg May vezetése, hitelvesztése láthatóvá válik, addig Corbyn története eröre kap.

11. ábra: A pártok támogatottsága 2016. július és 2017. május között a pártot választani tudó biztos szavazók körében

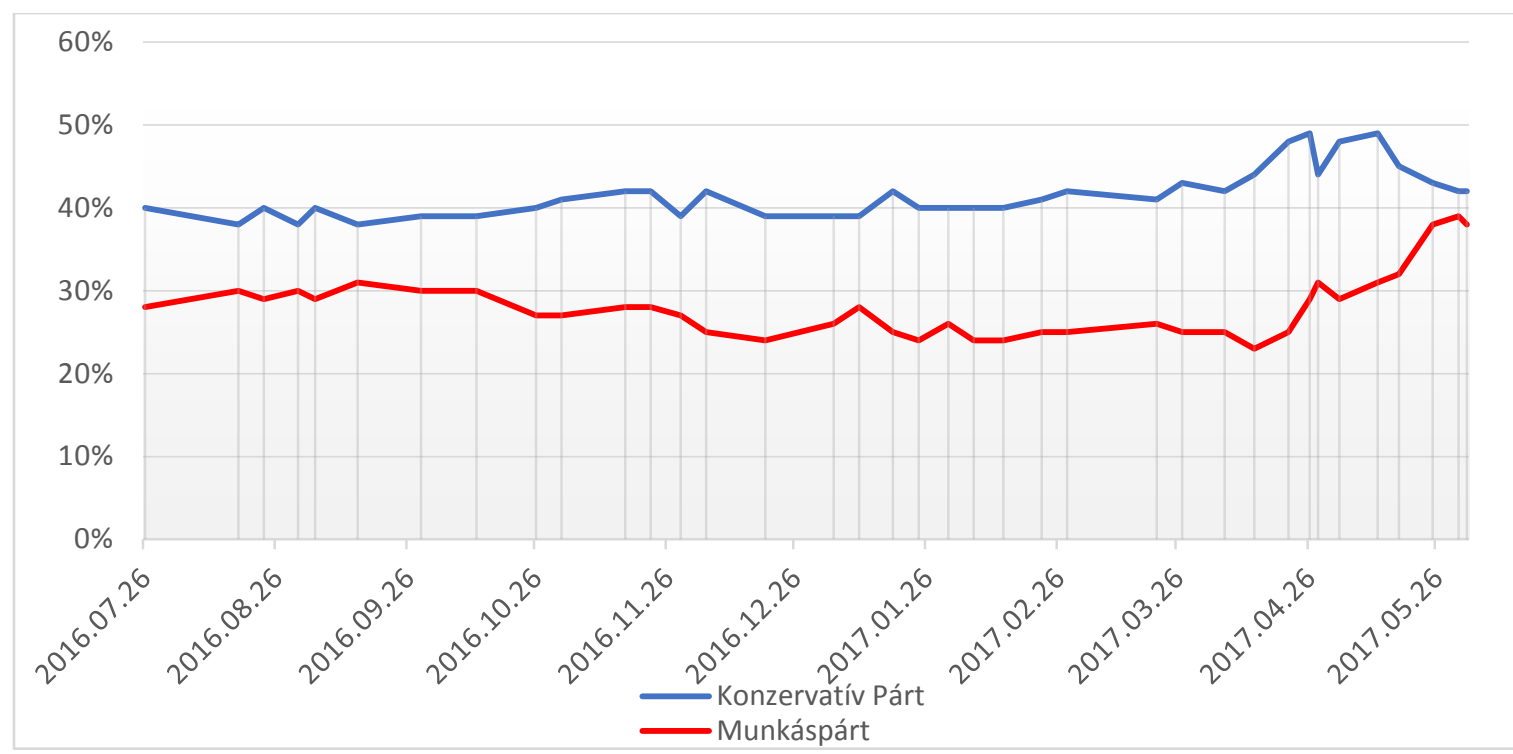

Forrás: YouGov (saját gyüjtés) 
12. ábra: A vezetök alkalmasságának megitélése 2016. július és 2017. május között ${ }^{107}$

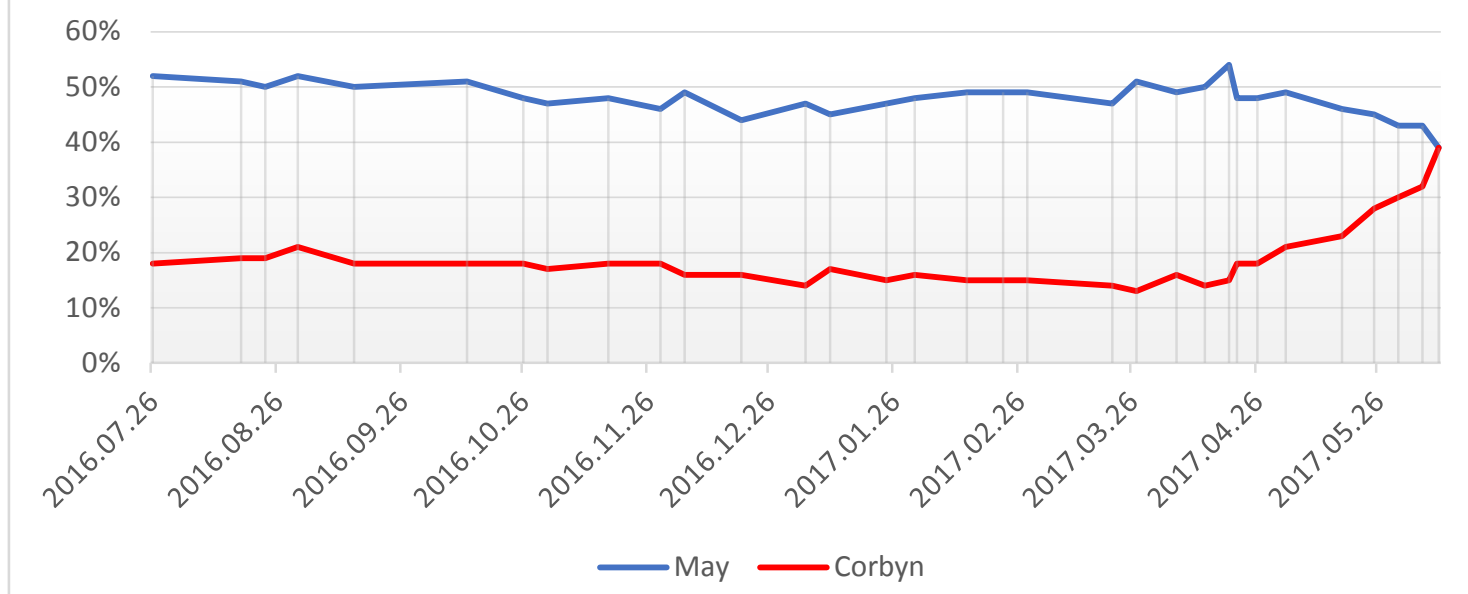

Forrás: YouGov (saját gyüjtés)

13. ábra: Theresa May elfogadottsági indexének alakulása 2016. július és 2017. május között ${ }^{108}$

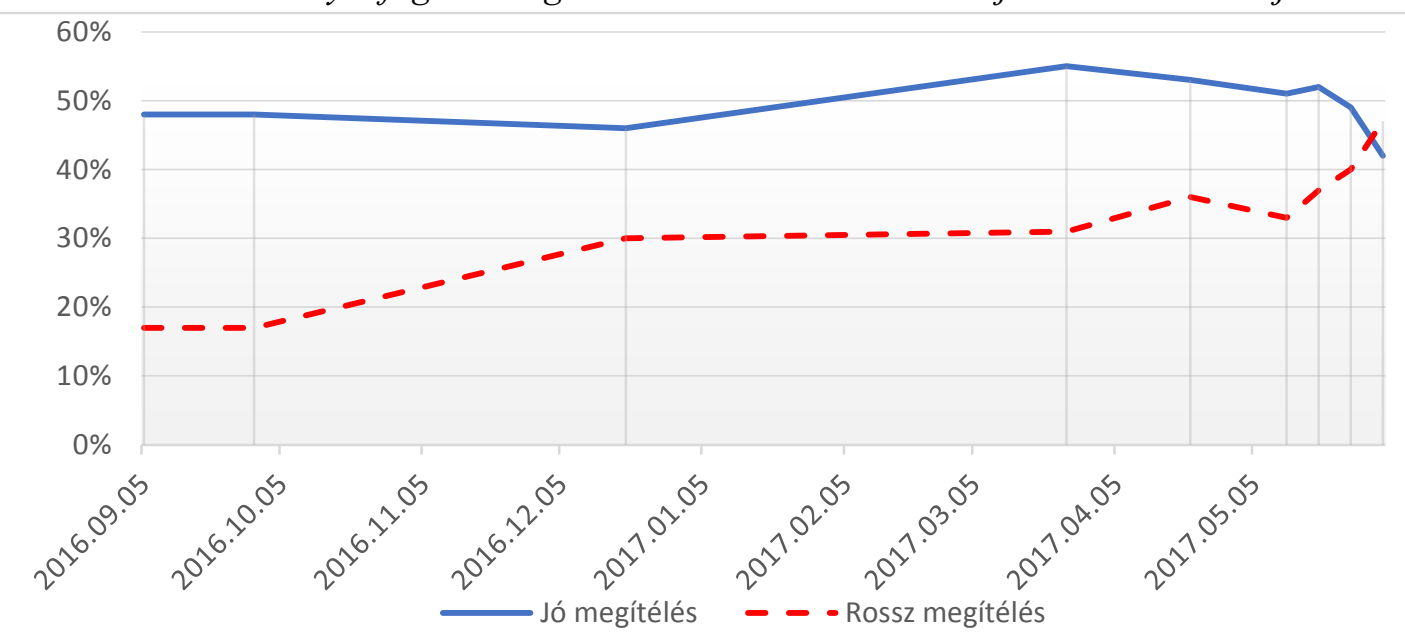

Forrás: YouGov (saját gyüjtés)

14. ábra: Jeremy Corbyn elfogadottsági indexének alakulása 2016. július és 2017. május között ${ }^{109}$

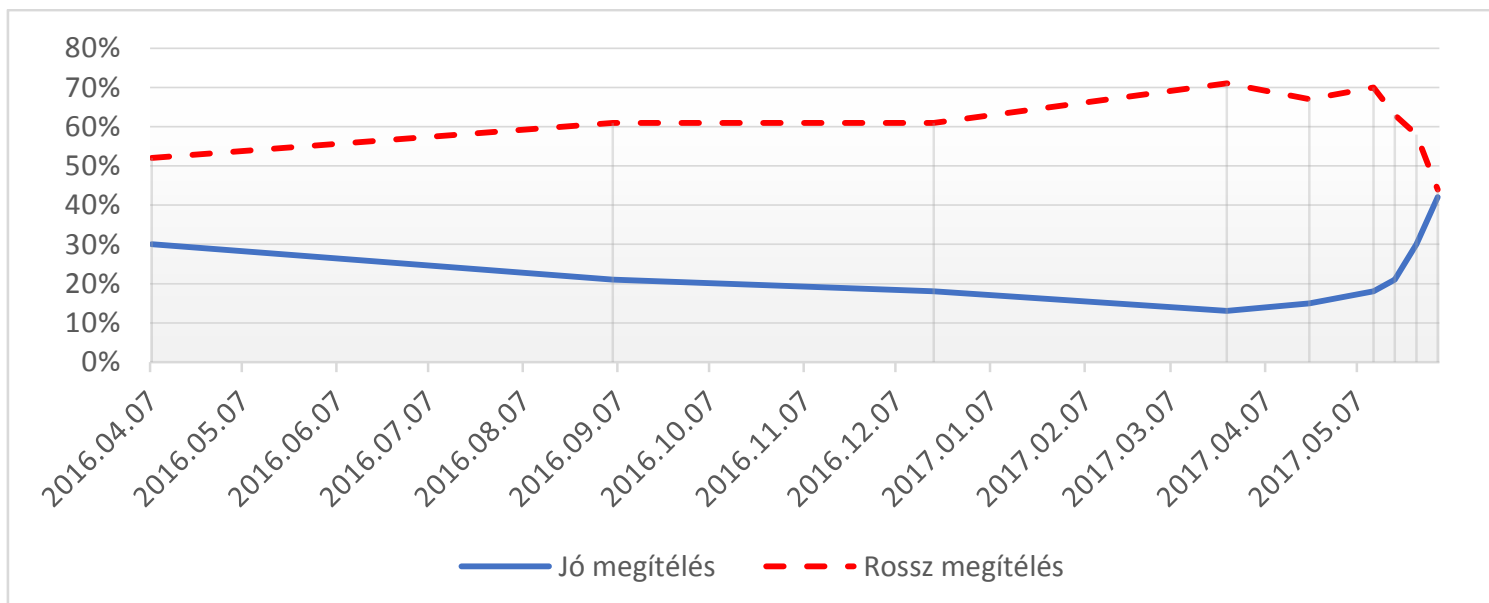

Forrás: YouGov (saját gyüjtés)

\footnotetext{
${ }^{107}$ A YouGov kérdése: „Which of the following do you think would make the best Prime Minister?” ${ }^{108}$ A YouGov kérdése: „Do you think that Theresa May is doing well or badly as Prime Minister?”

109 A YouGov kérdése: „Do you think Jeremy Corbyn is doing well or badly as leader of the Labour party?"
} 
Ez több dologra is visszavezethető. Egyrészt Corbyn saját vezetői történetébe tudta illeszteni a Brexit kérdését, amely komoly kihívásnak ígérkezett negatív morális hozadéka miatt. Söt ez különösen problematikus volt annak fényében, hogy amíg Corbyn régóta kritikus hangot ütött meg az EU-val kapcsolatban és csak kényszerüen és vonakodva támogatta a maradást, addig követői egyértelműen a maradás mellett álltak ki. Másrészt Corbyn ki tudta használni erőforrásait és érvényre tudta juttatni saját „demokratikusabb”, mozgalmi politikáját a kampány alatt. Harmadrészt döntő jelentőségü volt, hogy amíg Corbyn hiteles tudott maradni az általa felajánlott vezetéshez; addig May vezetése több ponton is ellentmondásba keveredett és kiüresedett. A közvélemény-kutatások (YouGov 2017a) is rámutattak arra, hogy May valóban „erősnek”, míg Corbyn inkább ,gyengének” tűnt a választók szemében, mégis egy év leforgása alatt Corbyn kompetensebbé, közvetlenebbé, erősebbé és őszintébbé vált, míg May megítélése ellenkező irányba fordult.

Összességében a választások eredményei jól mutatják a két vezetői történet elfogadottságát. Pontosabban azt, hogy a vezetők mennyiben tudták saját történetüket elfogadtatni és követőiket mobilizálni. A kampány során is erre helyeződött a legnagyobb hangsúly. A konzervatív kampány elsősorban May személyére épített, mintsem a Konzervatív Pártra. Mindazonáltal May számára természetellenesnek tűnt a kampányüzemmód (Prosser 2018, pp. 4-5): kellemetlenné váltak a választókkal való találkozások, gúny tárgyává vált az „erős és stabil vezetés” szlogenje, a szakpolitikai hibák után meghátrálást tanúsított, de negatív színben tüntette fel a televíziós vitától való elzárkózás is. Mindezen túl különösen negatívan érintette May erős vezetésképét a kampány alatt történő manchesteri és londoni terrortámadás is. Ezzel szemben Corbyn született kampányoló volt, amelyet csak tovább erösített a népszerüvé vált megszorításellenes, államosító programja és szakpolitikai ígéretei (pl. az egyetemi tandíj eltörlése). A terrortámadásokat követően sikerült rámutatnia May gyengeségére és korábbi hibáira (a rendőrség és a biztonsági szolgálatok támogatásának megvonását, belügyminiszteri időszakából) és elkerülnie, hogy korábbi kapcsolatai különféle terrorista csoportokkal (Hamas, Hezbollah, IRA) előtérbe kerüljenek.

Mindezek nyomán a 2017. június 8-án tartott előrehozott választásokon ugyan a Konzervatív Párt győzelmet ért el, megszerezte a mandátumok többségét (317) és 5,5\%kal több szavazatot (42,4\%) kaptak, mint 2015-ben, amely Margaret Thatcher földcsuszamlásszerü 1983-as győzelme óta a legjobb eredménynek számított, mégis 13 mandátum elvesztésével meghiúsult az abszolút többségük. May tehát megnyerte a 
választást, mégis eljátszotta előnyét, és az észak-ír Demokrata Unionista Párt külső támogatásával kisebbségi kormányzásra kényszerült, beszükítve ezzel saját mozgásterét. Így az erős és stabil vezetésből gyenge és roskatag (,,weak and wobbly”: Bale és Webb 2017) vezetés lett. A Munkáspárt jelentősen, mintegy 9,5 százalékkal növelte szavazatainak számát (40\%) a 2015-ös választásokhoz képest, amely 30 plusz mandátumot jelentett.

A választási és parlamenti pártok effektív száma hirtelen csökkenést mutattak és a választáson a két nagy párt megszerezte a leadott szavazatok 82,3\%-át, visszafordítva ezzel a pártrendszer fragmentálódását (Prosser 2018). Amíg a pártok effektív száma kevesebb volt, mint 2010-ben és 2015-ben, addig a két pártra leadott szavazatok száma 1970 óta a legnagyobb volt. Amíg a konzervatívok a távozáspártiak támogatásából, s így az euroszkeptikus UKIP (UK Independence Party) összeomlásából profitáltak, addig a Munkáspárt a maradáspárti és a távozáspárti szavazatokat egyaránt be tudta gyüjteni; sikerült a 2015-ben rájuk szavazókat visszanyerniük, valamint a liberális, demokrata és zöldpárti szimpatizánsokat és a bizonytalanokat megszólítaniuk (Mellon és mtsai. 2018). Mellon és munkatársai (2018) aláhúzzák, hogy a legfontosabb faktor a kampányban a vezetők - elsősorban Corbyn - értékelésének a megváltozása volt. Másképpen fogalmazva a Munkáspárt előretörése és a Konzervatív Párt visszaszorulása a vezetőik megítélésében történő változásnak köszönhető. Ennek nyomán, amíg May mandátumának megerősítésében kudarcot vallott, addig Corbynnak nemcsak sikerült vezetését megmentenie, de be is biztosította azt.

\section{7. Összegzés}

A vizsgált időszakot expliciten is az a kérdés határozta meg, hogy ki képes a „megfelelő” vezetést biztosítani az országnak ebben az átmeneti és bizonytalan időszakban. Theresa May és Jeremy Corbyn vezetését tárgyaló esettanulmány több szempontból is érdekesnek bizonyult. Egyfelől több ponton is hasonlóságokat mutattak a vezetői történetek, mégis a közös kiinduló alapból (követők csoportjának meghatározásából) ellenkező következtetéseket vontak le. Másfelől May vezetésében megmutatkozó ellentmondások következményei kézzelfoghatóvá váltak a követés tekintetében, azaz a választói preferenciák alakulásában. Összegzésként tekintsük át pontról pontra, hogy milyen típusú vezetést mutattak fel a vezetők történetükben ( 9 . táblázat). 
May és Corbyn egyaránt látták a Brexitben rejlő bizonytalanságot és lehetőségeket. A bizonytalanság nem valamilyen külső tényezőből, hanem a vezetők hatékonyságot rontó (Corbyn), és a morális alapokat veszélyeztető (May) politikájából fakadt. A bizonytalanság leküzdése tehát nem karizmatikus vezetést hívott elő. A Brexit May számára a „politikacsinálás” (tranzaktív vezetés), amely a népszavazáson kinyilvánított preferenciák és közérdek, valamint a kormányzás összekapcsolását jelentette. Corbyn számára a Brexit értelmezése nehézséget jelentett, annak negatív morális hozadéka és kényszerű maradáspártisága miatt. A problémát egy erős morális állásponttal tudta áthidalni, amelyet bizonyos baloldali és liberális értékek mentén megvalósuló morális alapítás (transzformatív vezetés) gondolata táplált.

9. táblázat: Theresa May és Jeremy Corbyn vezetéskonstrukciója

\begin{tabular}{|c|c|c|}
\hline & Theresa May & Jeremy Corbyn \\
\hline \multicolumn{3}{|c|}{$A, j$ jó" vezetés } \\
\hline Kihívások & $\begin{array}{l}\text { politikacsinálás (a választói akarat, a } \\
\text { közérdek, Brexit végrehajtása) } \\
\text { - a közérdek kialakítása (,Brexit means } \\
\text { Brexit”, „Global Britain”, „Great } \\
\text { Meritocracy”) } \\
\text { - politikai részvétel biztosítása („Give } \\
\text { me the mandate”, előrehozott } \\
\text { parlamenti választások) } \\
\text { (tranzaktív vezetés) }\end{array}$ & $\begin{array}{l}\begin{array}{l}\text { morális alapítás } \\
\text { demokratikusabb } \\
\text { megteremtése) }\end{array} \\
\text { - } \begin{array}{r}\text { morális iránymutatás } \\
\text { közvetítése) } \\
\text { politika }\end{array} \\
\text { - } \begin{array}{l}\text { követök beemeléke a politikába } \\
\text { (,empowering”, állandó }\end{array} \\
\text { mobilizáció és mozgalmi politika) } \\
\text { - } \begin{array}{l}\text { konstruktív problémamegoldás } \\
\text { (,human rights language”, nyílt }\end{array} \\
\begin{array}{l}\text { politikai diskurzus) } \\
\text { (transzformatív vezetés) }\end{array}\end{array}$ \\
\hline $\begin{array}{l}\text { Politikai } \\
\text { tudás }\end{array}$ & $\begin{array}{l}\text { tekhné (Brexit, mint termék legyártása és } \\
\text { leszállítása [,deliver”], kemény hatalmi } \\
\text { eszközök és ösztönzök: „,no deal is better } \\
\text { than a bad deal”, „,bloody difficult } \\
\text { woman”) (tranzaktív vezetés) }\end{array}$ & $\begin{array}{l}\text { episztémé (morális karakter) } \\
\text { (transzformativ vezetés) }\end{array}$ \\
\hline \multicolumn{3}{|c|}{ A ,helyes” kapcsolat } \\
\hline $\begin{array}{l}\text { Hatalmi } \\
\text { kapcsolat }\end{array}$ & $\begin{array}{l}\text { a hatalom mások feletti gyakorlása } \\
\text { (power over) („Give me the mandate”, } \\
\text { hatalmi eszközök) } \\
\qquad \text { (tranzaktív vezetés) }\end{array}$ & $\begin{array}{l}\text { a hatalom kollektív gyakorlása (power } \\
\text { with) (grassroots mozgósítás a } \\
\text { kihívások leküzdésében) } \\
\quad \text { (transzformativ vezetés) }\end{array}$ \\
\hline $\begin{array}{l}\text { Interakciók } \\
\text { iránya }\end{array}$ & $\begin{array}{l}\text { vertikális } \quad \text { (vezetés pozicionálás } \\
\text { megközelítése, érdekalapú kapcsolat) } \\
(\text { tranzaktív vezetés })\end{array}$ & $\begin{array}{l}\text { horizontális (részvételen és értékeken } \\
\text { alapuló kapcsolat) } \\
\text { (transzformatív vezetés) }\end{array}$ \\
\hline $\begin{array}{l}\text { a követők } \\
\text { szerepe }\end{array}$ & $\begin{array}{l}\text { reaktív (maradáspárti pozíció feladása, } \\
\text { kormányalakítás) } \\
\text { proaktív (Brexit kemény értelmezése, } \\
\text { kezdeményezés és preferenciák } \\
\text { alakításának szándékával) } \\
\text { proaktív (preferenciáját és érdekét a } \\
\text { népszavazáson kifejező átlagember) } \\
\text { (tranzaktív vezetés }>\text { karizmatikus vezetés) }\end{array}$ & $\begin{array}{l}\text { koaktív (vezeti a politika áramlását, de } \\
\text { nem uralja) } \\
\text { koaktív (átlagember, mint követők } \\
\text { bevonása, mozgalmi politika) } \\
\quad \text { (transzformatív vezetés) }\end{array}$ \\
\hline
\end{tabular}


A corbyni morális alapítás egy „kedvesebb” (demokratikusabb) politika kialakítását jelentette. Értelmezésében a népszavazás nem a demokrácia megnyilvánulása volt, hanem egy segélykiáltás egy még demokratikusabb és igazságosabb politikáért és társadalomért. Így Corbyn számára a Brexit lehetőséget és tökéletes táptalajt jelentett a korábban meghirdetett új politika víziójának. Ehhez elengedhetetlen a morális iránymutatása, amellyel értékeket (pl. a társadalmi igazságosságot, szolidaritást, egyenlőséget és az internacionalizmust) közvetít és testesít meg. Ehhez párosult további célként a követők felhatalmazása és beemelése a politikába, amely a taktikaalkotásban, az állandó mobilizációban és mozgalmi politikában meg is mutatkozott. Ugyancsak fontos elemnek bizonyult a konstruktív problémamegoldás és konfliktuskezelés is, amely a vitára való nyitottságot (,human rights language”) és a diskurzus kitágítását, zavaró tényezők (a rasszizmus és az idegenellenesség) kiszürését irányozta előre.

Ezzel szemben May víziója az átlagember érdekét érvényesítő pragmatista politikára szorítkozott, amely a közérdek kialakításában és a preferenciák újbóli kinyilvánításához kellő politikai részvétel biztosításában öltött testet. May a népszavazáson megfogalmazott közérdek értelmezésére tett kísérletet. A Brexit csak egyetlen olvasatát ismerte el („Brexit means Brexit”), amely kizárólag az átlagember kívánságának érvényesítését és végrehajtását írja elő a vezetőnek. Számára a népszavazás a demokrácia egyértelmü megnyilvánulása volt, amely visszaállította a brit parlamenti demokráciát és a nemzeti önrendelkezést. May a közérdek tartalmát illetően egy külpolitikai („Global Britain”) és egy belpolitikai („Great Meritocracy”) célt is megfogalmazott. Mindehhez azonban stabilabb és erősebb mandátumra volt szüksége, amelyet az elörehozott választásokon való részvétel biztosítása és a választói akarat újbóli kinyilvánítása révén kívánt elérni. Összességében May politikája megközelíti a karizmatikus vezetést (új rend kialakításának igénye), de nem egy érzelmi (karizmatikus) kapcsolat kialakítását és az alkalmasság bizonyítását célozta meg, hanem egy érdekalapú viszony megerősítésére, és a Brexit technikai lebonyolítására vállalkozott.

\section{Milyen politikai tudást igényelt a célok elérése és a megfelelö eszközök kiválasztása?}

A vízió- és taktikaalkotás felfedte a vezetők által használt és helyesként definiált eszközöket és az általuk megtestesített politikai tudást. Theresa May „szakértőként” és „profi” menedzserként tünt fel, aki feladatát technikai problémának értelmezte, $\mathrm{s}$ „teljesíti” és „kézbesíti” (deliver) a választói akaratot kielégítő politikát, a változást, a legjobb egyezséget a kilépési tárgyalások (,,no deal is better than a bad deal”, „bloody 
difficult woman") során. Az erōs és biztos vezetés a feladat teljesítésében mutatkozott meg és kemény hatalmi eszközök és szelektív ösztönzők használatát jelentett. Mindez egyfajta technikai és produktív tudást (tekhné) igényel. Ezzel szemben Jeremy Corbyn vezetői hitelességét épp morális karaktere és ideológiai tudása (episztémé) adta, amely lényegében áthatotta politikáját. A morális alapítás kihívása megkívánja az ideológiai (értékek által vezérelt) gondolkodást (azaz érzületetikát), amelyet Corbyn pártjából és követőinek mozgalmából eredeztetett. Végeredményében olyan politikai tanítóvá és morális vezetővé nőtte ki magát, akit egyfajta személyi kultusz övezett követői és támogatói körében.

\section{Miképpen értelmezhetö a vezetök és a követők hatalmi viszonya?}

A követők vezetőkhöz való kapcsolódásának kérdése komoly problémát jelentett a Brexit természetéből fakadóan, amely megnövelte a távolságot a két fél között. E távolság csökkentése érdekében a vezetők rendezni kívánták a hatalmi viszonyokat. May által leírt történetből egy pozíció-centrikus és „énközpontú” vezetésértelmezés és a kemény hatalmi eszközök és ösztönzők használatának igénye rajzolódott ki, amelyekből leszürhető hatalomfelfogása is. May a kollektív célok eléréséhez a hatalmát mások felett (power over) kívánta gyakorolni. Ezzel szemben a Corbyn által vizionált demokratikus politika már a mozgalmi grassroots aktivitásban mutatkozott meg, amelyben a hatalom kollektív gyakorlásának ideája ( $p o w e r$ with) elevenedett meg.

\section{Milyen pályát írtak le a vezetők és a követők közötti interakciók?}

A hatalmi viszony a vezetők és követők közötti interakciókban is tükröződött. Amíg May egy érdekalapú horizontális kapcsolatot vázolt fel, addig Corbyn bizonyos értékek, és a részvétel mentén kapcsolódott horizontális módon követőihez.

\section{Milyen szerepet kaptak a vezetők és a követök a vezetés folyamatában?}

A két vezető egyaránt a munkából élő, de a politika által elfeledett átlagembert kívánta megszólítani, így ők jelentették számukra a követők csoportját. Viszont amíg May egyfajta érdekközösséget feltételezett, amely proaktív módon kapcsolódott a politika folyamatához, addig Corbyn ugyanazon csoportot már morális (érték) közösségéként írta le, amelynek tagjaitól kölcsönösen aktív részvételt várt el, a Brexit körül kialakult kihívások leküzdésében. Ennek megfelelően Corbyn saját szerepét illetően is kölcsönös aktivitást mutatott a személyes részvételével az állandó mobilizáció és mozgalmi politika során. May által felmutatott tranzaktív vezetés reaktív szerepet vetített előre, amely alárendeli magát a követők akaratának és annak érvényesítésére törekszik. Ez 
mutatkozott meg maradáspárti pozíciójának feladásán és a kormányátalakítási stratégiában, azonban a Brexit kemény értelmezésével nem segítette elő egy társadalmi kompromisszum kialakulását. Sőt egy proaktív, kezdeményező szerepbe lépett, amely ellentmondást szült vezetésében, megkérdőjelezve vezetői hitelességét.

15. ábra: Theresa May és Jeremy Corbyn vezetéskonstrukciói

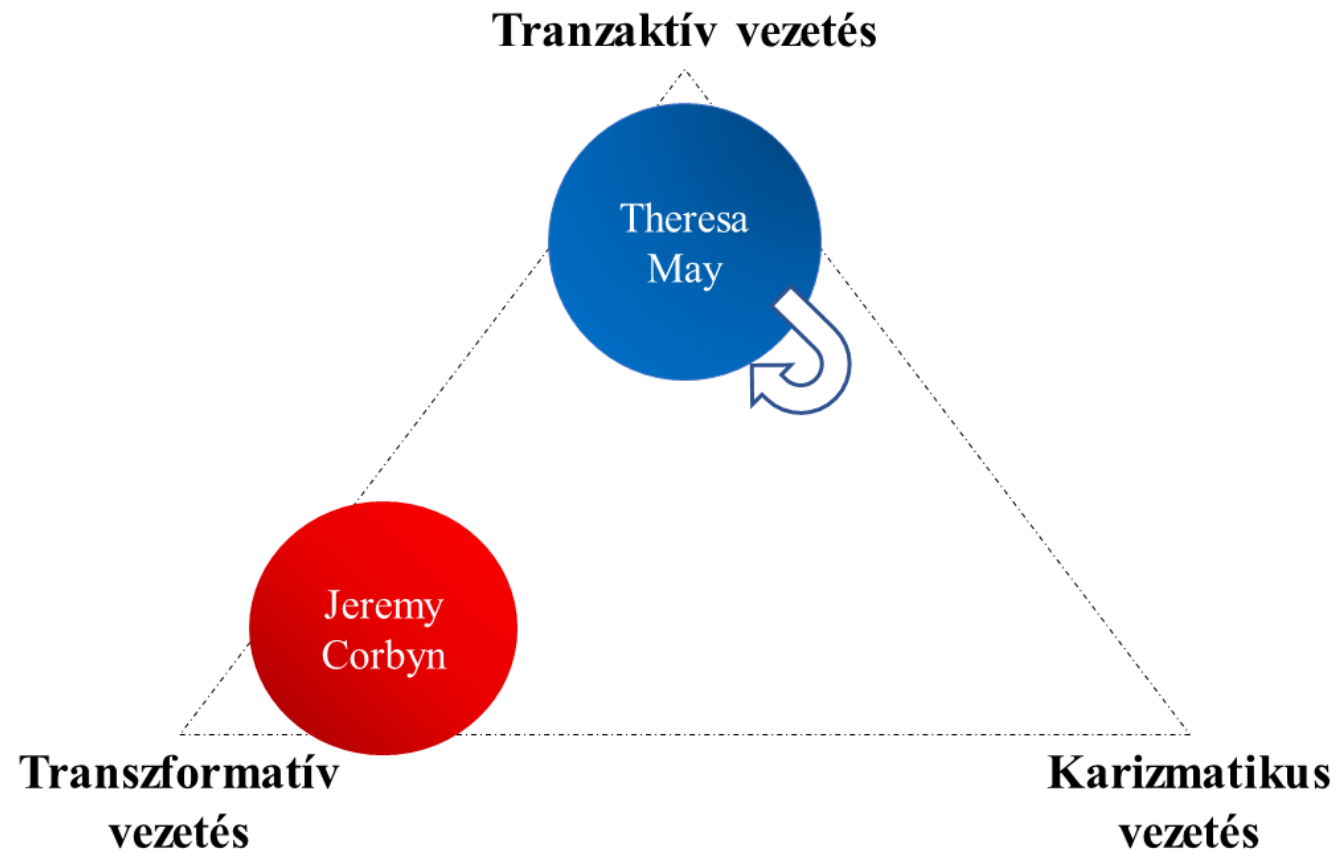

Összességében nem túlzás azt állítani, hogy a 2017-es parlamenti választások a vezetők hitelességét mérte. Amíg Corbyn hitelesen meg tudta testesíteni a transzformatív vezetést a Brexithez kapcsolt kihívások morális értelmezésével és ahhoz kapcsolt mozgalmi politikával, addig May tranzaktív vezetése elvesztette hitelét, amelyet egyfelől a taktikájában (szerepértelmezésében) megmutatkozó ellentmondásoknak, másfelöl a kihívások (közérdek kialakítása, politikai részvétel biztosítása a preferenciák kinyilvánításához) elégtelen teljesítésének köszönhetett (15. ábra). Mindez nem feltétlenül jelenti azt, hogy Corbyn sikeresebben és hatékonyabban kezelné ezt az átmeneti helyzetet, csupán azt, hogy Corbyn-ról egyre több választó tudta ezt elhinni May-jel szemben. Az eset tanulsága az sem lehet, hogy egyik vagy másik vezetéstípus alkalmasabb lenne a többinél a helyzet kezelésében. May egyszerüen többre (azaz egyfajta karizmatikus vezetésre) vállalkozott, mint amit elvárta tőle vagy épp, amire megteremtette volna a kellő igényt. Így hitelességét elveszítve „egyszerüen” nem tudott megfelelö kapcsolatot kialakítani potenciális követőivel, amely a vezetésének határait vagy rosszabb esetben a végét vetítette elöre. 


\section{0. ÖSSZEFOGLALÁS ÉS KÖVETKEZTETÉSEK}

A disszertáció zárófejezetéhez érve, összefoglalom a kutatás föbb eredményeit, majd levonok néhány következtetést. Reflektálok a kutatás elején (1. fejezet) megfogalmazott gondolatokra és tézisre, valamint az ott feltett kutatási kérdésekre.

A kutatásom kezdetén azt a tézist fogalmaztam meg, hogy a demokrácia és a politikai vezetés között nem, hogy nincs ellentmondás, de a fogalmakat és gyakorlatot tekintve még egy szoros kapcsolat is felfedezhető. A jelen vezetéselméleti kutatás arra a két összekapcsolódó kérdésre kereste a választ, hogy a demokratikus vezetés problémája miképpen oldható fel gondolati (elméleti) szinten és miképpen oldódik meg az a gyakorlatban. Ennek megfelelően a kutatás célja az volt, hogy megértse a demokratikus vezetést elméleti és gyakorlati szinten egyaránt, amelyet egy vezetéstipológia felállításával és alkalmazásával kíséreltem meg. A vizsgálat egy két perspektívát magában foglaló konstruktivista megközelítés szerint folyt. A disszertáció első részében három demokráciaelmélet keretében határoztam meg a demokratikus vezetés egy-egy típusát, így kialakítva egy vezetéstipológiát. A demokratikus vezetés, mint elméleti konstrukció kapcsán arra voltam kíváncsi, hogy miként lehet gondolkodni a jó vezetésről és a vezetők és követők közötti helyes kapcsolatról a különböző - morális, materiális és politikai - demokráciaértelmezések keretében. A második részben végzett empirikus kutatás során ezen vezetéstípusok és tipológia mentén elemeztem Angela Merkel, Orbán Viktor, Theresa May és Jeremy Corbyn vezetését. A demokratikus vezetés, mint gyakorlati konstrukció kapcsán azt a kérdést fogalmaztam meg, hogy miként konstruálódik meg a demokratikus vezetés a gyakorlatban. A vállalkozás újszerü és hiánypótló jellege a szakirodalmi megoldási stratégiákat meghaladó tézisében, a kétirányú (elméleti és gyakorlati szintet egyszerre átölelő) konstruktivista megközelítésében és a kérdés plurális olvasatát lehetővé tevő tipológiában állt.

Ebben a fejezetben felidézem és összefoglalom a kutatás főbb eredményeit és mondanivalóját, amelyet az esettanulmányok fényében kiegészítek. Az első részben röviden összegzem a kutatási problémát, valamint a demokrácia és a vezetés kapcsolatát. A második részben áttekintem az esettanulmányok eredményeit és tanulságát a vezetés típusok fényében. Végül, a harmadik részben szélesebb perspektívába helyezem a kutatás eredményeit. 


\subsection{A politikai vezetés és a demokrácia fogalmi és gyakorlati kapcsolódása}

A disszertáció bevezető fejezetében azt az erős állítást fogalmaztam meg, hogy nincs demokrácia vezetés nélkül, vagy fordítva vezetés demokrácia nélkül. Ez azonban korántsem magától értetődő. Ezért ezen a ponton célszerünek tűnik feleleveníteni a kutatás kiinduló problémáját és tézisét.

A tudományos diskurzusban széles körben tartja magát az a makacs gondolat, hogy a demokrácia és a (politikai) vezetés között egy mély ellentmondás húzódik. Mindez, amelyet a demokratikus vezetés problémájának neveztem, onnan ered, hogy a demokráciához és a vezetéshez kötött fogalmi társítások ellentétesek. Hisz amíg a demokrácia az önkormányzás, a népszuverenitás és az egyenlőség ideáját testesíti meg, addig a vezetés a hatalom, a manipuláció és a hierarchia hordozója. A probléma azon a ponton realizálódik, mikor a politikai vezető hatalmát egyszerre kívánjuk korlátozni és felhatalmazni, hogy mások céljait elérje és érvényesítse. Azonban ez az ellentmondás csupán viszonylagos. Hiszen az, hogy mi ítélhető meg demokratikus vezetésnek, függ az érvényesíteni és védeni kívánt demokrácia ideájától (Ruscio 2008, pp. 4-6). S fordítva, a szükségesnek ítélt vezetés meghatározza azt, hogy miként lehet gondolkodni a demokratikus politikáról. Az ellentmondás feloldása tehát attól függ, hogy a vezetés és a demokrácia koncepcióját miképpen szabjuk egymáshoz (Beerbohm 2015, p. 639). A bemutatott (1.1. alfejezet) megoldási stratégiák jól láttatják, hogy a fogalmak kibékíthetők.

Túllépve a kibékítés megoldásán, a tézisemben úgy fogalmaztam, hogy a vezetés és demokrácia szorosan függenek egymástól fogalmi és gyakorlati szinten egyaránt (1.2. alfejezet). A két fogalom - mint „lényegüket tekintve vitatott koncepciók” (Gallie 1955/56) és univerzális „bálványfogalmak” (Brunner, Conze, és Koselleck 1999, pp. 156-57) - tartalmukat tekintve bizonytalanság és állandó revízió tárgyai, amely akár ellentétes értelmezéshez is vezethet. Ez a fogalmi dinamika rámutat arra, hogy mind a demokrácia, mind a vezetés a legjobb kormányzás ígéretét jelöli, amelynek tartalma viszont igen változatos képet mutat. Ennélfogva a demokratikus vezetés ugyancsak egyfajta hit tárgyává válik, amelyet a vezetők és a követők egyaránt formálnak.

A kölcsönös fogalmi függés lényege abban rejlik, hogy a (demokratikus) vezetés a társadalmi és politikai kapcsolatok rendezésének, valamint a kormányzó kevesek kiválasztásának egy olyan új módját jelöli, amely a demokrácia gyakorlatát adja (Wren 2007, p. 2). Hiszen, amíg a demokrácia széles értelemben olyan rendszerként 
definiálható, amely a kormányzók és kormányzottak kapcsolatát egyedi módon szervezi meg (Schmitter és Karl 1991, pp. 76-77), addig a vezetés egy olyan befolyásolási pálya a vezetők és követök között, amely meghatározott célok eléréséért jött létre (Wren 2007, p. 2). A vezetők és követők kapcsolatának meghatározásának ezen új módja elkerülhetetlenül magában foglalja a hatásgyakorlást és a közöttük futó interakciókat (stabil denotáció: 1.3.1. alfejezet). Ugyanakkor nem azonosítható egy adott pozíció betöltésével (formális autoritással), s így a nyers hatalomgyakorlással, a kormányzással és az elit kizárólagos cselekvésével (fogalmi lehatárolás: 1.3.2. alfejezet). Mindezeken túl a vezetés inherens normatív tartalommal is rendelkezik (normatív konnotáció: 1.3.2. alfejezet), amely megkívánja az etikusság és a hatékonyság egy meghatározott formáját és módját, illetve a követők e hatalmi viszonyba való önkéntes beleegyezését.

A demokrácia gyakorlataként a vezetésnek igazolnia kell önmagát, hogy a cselekvést és a két fél közötti kapcsolatot fenntartsa. Azaz: a vezetésnek valamilyen választ kell adnia arra milyen a ,jó” (hatékony/morális) vezetés, illetve a vezetők és követők közötti „helyes” kapcsolat. Ezzel a vezetés formatív és konstitutív módon megteremti a maga demokratikus valóságát, igazodva a demokráciával szemben támasztott elvárásokhoz. Ez két dolgot is jelent: egyrészt a demokrácia állandó igazolásának kívánalmát kizárólag a vezetés képes megteremteni, másrészt a vezetést a népuralomból, a népszuverenitásból fakadó konstans legitimitásigény maga is formálja. Ezen a ponton válik a fogalmi párhuzamból gyakorlatban is megjelenő szoros kapcsolat és függés, ugyanis mindezzel - tartalmától függetlenül - valamilyen módon hozzájárul a demokratikus politika folyamatához.

Ilyen módon a demokrácia és a vezetés közötti fogalmi és gyakorlati függést - annak pontos tartalmától eltekintve - általánosan igaznak fogadtam el. A kapcsolat korlátját az az önigazolás jelenti, amely a jó vezetés hatékonyságának és etikusságának „önkéntes” elfogadását, valamint a hatalmi viszonyba (helyes kapcsolatba) való beleegyezését kéri a követőktől - legalábbis formálisan.

\subsection{A demokratikus vezetés típusai az esettanulmányok fényében}

A bevezető fejezetben azt feltételeztem, hogy a demokrácia legitimáció kényszere nyomán a politikai vezetők - követőik támogatásával - megalkotják a demokratikus valóságukat. A négy kiválasztott vezető önigazolási tevékenységét a demokratikus vezetés tipológiája mentén bontottam ki. Alábbiakban előbb összegzem miként járulnak hozzá a különböző vezetéstípusok az adott demokráciához, majd levonom az esettanulmányok tanulságait. 
A demokrácia és a vezetés kapcsolatának konkretizálása során az első lépés a három demokráciaelmélet premisszáinak feltárása volt (3.1., 4.1. és 5.1. alfejezet). A deliberatív-részvételi demokrácia egy morális értelmezést jelenít meg azzal, hogy normatív célként az állampolgári politikai kontroll és autonómia növelését tüzi ki. Ezzel szemben az aggregatív-pluralista demokrácia központi problémája már materiális jellegü. Az elmélet arra a kérdésre fókuszál, hogy miként lehet a preferenciákból kormányprogram vagy közpolitika, illetőleg miként lesz az érdekekböl hatalom, hatalmi tényező a demokratikus keretek fenntartásával. A vezérdemokrácia elmélete viszont a demokratikus politikában már csak egy módszert lát a kormányzásra alkalmas vezetők kiválasztására. Az elméletek eltérő premisszákat határoznak meg az állampolgárokra, a részvételre, a politika folyamatára, irányára és végeredményére vonatkozóan.

$\mathrm{Az}$ eltérő politikaképből fakadóan a három demokráciaelméletben a vezetés is specifikus módon merül fel. Pontosabban: a vezetés különbözőképp kapcsolódik és járul hozzá a demokratikus politika folyamatához, illetve rendezi a ,jó” vezetés és a vezetők és követők „helyes” kapcsolatának kérdését.

- A deliberatív-részvételi demokráciában a transzformatív vezetés (3.2. alfejezet) érvényesülhet, amely előtt kihívásként a morális alapítás áll. Itt a vezetés a demokratikus politika kialakítására és fenntartására vállalkozik, amely során a vezető egyfajta morális tanítóként mutatja az irányt, elősegíti a konfliktusok és problémák konstruktív megoldását és beemeli a követőit a politikai folyamatba. Ezzel lehetővé válik az állampolgárok közvetlen (nem konvencionális) részvétele, személyük és preferenciáik transzformációja. A transzformatív vezetés megalapozza és elősegíti a bottom-up politikai folyamatot, a preferenciák többoldalú alakítását és a mindenki által elfogadható méltányos döntést. Ebben a folyamatban a vezető „,egyszerü” kötelességtudó állampolgár, akihez a követők értékek, és a közös részvétel, hatalomgyakorlás mentén kötődnek.

- Az aggregatív-pluralista demokrácia egy piaci cserére alapuló tranzaktív vezetést (4.2. alfejezet) hív elő. A vezető itt mesteremberként vagy gépészként „,csinálja” a politikát: aggregálja és képviseli a preferenciákat, kialakít egy kompromisszumot, azaz összekapcsolja az egyéni preferenciákat, csoportos érdekeket a népakaratot megtestesítő kormányzással. Ehhez a vezetés fenntartja azt a kollektív cselekvést, amellyel az állampolgárok kinyilvánítják a preferenciáikat, és kialakítja („,legyártja”) a közérdeket megtestesítő közakaratot. 
Mindezzel megvalósulhat a polgárok konvencionális részvétele, a preferenciák mechanikus összegzése és a kompromisszum. A tranzaktív vezetés nem feltétlenül nélkülözi az idealizmust vagy populizmust sem. Hiszen a vezetőnek egyszerre kell tisztelnie az intézményeket és az azokat övező modális értékeket, valamint érvényesítenie, reaktív módon kiszolgálnia a mindenkori többség akaratát. Ezáltal a politikai folyamat bottom-up jellege és a vezető kiemelt szerepe (a hatalom mások feletti gyakorlása és a vertikális érdekkapcsolat) is megmarad.

- A vezérdemokrácia expliciten azonosítja a demokratikus politikát a karizmatikus vezetéssel (5.2. alfejezet). A vezetés kezeli és megoldja a vélt vagy valós kollektív problémákat azzal, hogy leküzdi a politikában rejlő bizonytalanságot. A vezető bizonyítja alkalmasságát (karizmáját, politikai erényeit és tudását) követőinek, akik cserébe - lemondva a cselekvés lehetőségéről - felhatalmazzák a kormányzásra. Ez az érzelmi elköteleződésre épülő vertikális kapcsolat adja a politikai folyamat top-down jellegét. Ennek folyamán a vezér kinyilatkoztatásával egy új rendet hoz létre, lerombolja a régit, valamint biztosítja kiemelkedő, monopol helyzetét és proaktív szerepét. A követők bár reaktív szerepbe kényszerülnek, a követés és az engedelmesség mégsem lesz kikényszeríthető erősszakkal vagy fegyelmezéssel, hiszen a vezetőnek „családföként” védelmet kell nyújtania közösségének.

A demokrácia eltérő gyakorlataival állunk tehát szemben. Egyik típusra sem lehet azt mondani, hogy demokratikusabb vagy célravezetőbb lenne a társainál, hiszen nem csak tartalmuk és irányuk, de a megítélésüket szolgáló elméleti keretüket illetően is különböznek. Az így kialakított vezetéstípusok egy tipológiában állnak össze, amely heurisztikai eszközként lehetővé teszi a gyakorlatban megfogalmazódó demokratikus vezetés plurális olvasatát. A demokratikus vezetéstípusok viszonyítási pontként szolgáltak a vezetők tevékenységének értelmezésében.

Az esettanulmányok (8. és 9. fejezet) tanulsága alapján egyes vezetők (Orbán Viktor és Jeremy Corbyn) tisztábban rajzolnak fel egy-egy vezetéstípust, míg másoknál (Angela Merkel és Theresa May) keveredtek a különbözö elemek. Orbán Viktorra a karizmatikus -, Jeremy Corbynra a transzformatív vezetés volt jellemző. Angela Merkel tranzaktív vezetését egészítette ki transzformatív jegyekkel. Theresa May vezetői történetében viszont ellentmondások ütötték fel a fejüket. Ezzel kiüresedett a tőle elvárt tranzaktív vezetés, s beékelődtek a karizmatikus vezetésre valló jellegzetességek, 
amelyekre azonban nem tudta megteremteni az igényt. Az esettekkel kapcsolatban felmerül a kérdés, hogy mennyire kell egy-egy vezetésnek koherensnek lennie a képviselt vezetéstípust illetően.

A vezetői történetek belső koherenciájával kapcsolatban semmiképp sem jelenthető ki egyértelmüen, hogy a vezetés sikere (vezetők és követők kapcsolatának fenntartása) a vezetés egységességében rejlik. Nem feltétlenül szükséges egy típust teljességében megjeleníteni ahhoz, hogy a vezetés létrejöjjön és müködjön. Három ponton azonban számolni kell a koherencia kérdésével.

Egyrészt a vezetéstípusok egyes elemei kombinálhatók. Például, amíg Merkel képes volt ötvözni valamelyest a transzformatív vezetés morális iránymutatását a célok pragmatikus, tranzaktív végrehajtásával, addig May már ellentmondásba keveredett a saját maga által kialakított és elfogadtatott tranzaktív vezetésképpel azzal, hogy proaktív szerepre vállalkozott. Itt ne felejtsük el azt sem, hogy Merkel tudatosan mozdult el a transzformatív vezetés irányába fenntartva a rá jellemző tranzaktív vezetést. Ezzel szemben May kevésbé bizonyult átgondoltnak a vezetését illetően: nagyobb és szélesebb (karizmatikus) változásra vállalkozott, mint amit előzetesen vártak volna tőle. Az egyes vezetők tehát változtathatnak vezetésükön. Ehhez azonban fenn kell tartaniuk integritásukat és hitelességüket, azaz a meglévő vagy akár leendő követőik támogatását. Ugyanakkor azt is fontos aláhúzni, hogy a vezetéstípusok zárt logikai rendszert alkotnak, amelyekben az egyes szempontok egymásra épülnek. Például a transzformatív vezetésben megfogalmazódó felhatalmazás céljából egyenesen következik a követők koaktív értelmezése és a közös hatalomgyakorlás. Ezt Merkel - legalábbis szimbolikus szinten - teljesíteni tudta. A vezetői profilváltás tehát kockázatos lehet, hiszen a régi követőkkel kialakított kapcsolat rugalmatlanságot mutathat és az új követök még nem ismerhették fel a nekik kínált új vezetést.

Másrészt a koherencia a retorikai és performatív tevékenység közötti különbség kapcsán is sérülhet. Természetesen nem újdonság, hogy a vezetők nem mindig azt teszik, amit mondanak. Azonban ez egyes vezetők esetében nem jár végzetes következményekkel, míg másoknál igen, azaz erodálódhat a követők egy jelentős részével a kapcsolat, és így megszünhet maga a vezetés is. Könnyebben elképzelhető, hogy a transzformatív és a karizmatikus vezetés rugalmasabb, hiszen céljaik élvezik a prioritást eszközválasztásukkal szemben. Amíg egy transzformatív vezetőnek a végsőkig ki kell tartania értékei mellett, addig a karizmatikus vezetőnek - a fegyelmezéstől való tartózkodás mellett - „csak” meg kell óvnia közösségét. Ellenben a tranzaktív vezetést 
kiüresítheti, ha vezető az eszközeit teljesen alárendeli céljainak. Ugyanis a vezetés e formája a helyes eszközhasználaton nyugszik. A tranzaktív vezető csak teljesíti a követői igényeket a politikai támogatásért cserébe. A cserekapcsolatot övező bizalom viszont az eszközökön, az intézményeken, a procedúrákon és az ezeket övező értékeken nyugszik.

Itt fontosnak tünik aláhúzni, hogy ellenzékben a vezetőknek - lásd például Corbyn esetét - könnyebb megőrizniük ebből a szempontból az integritásukat, hiszen a valódi téttel és hatással járó performatív tevékenység csak inkumbensként realizálódhat teljességében. Ezért a változást ígérő transzformatív - és karizmatikus vezetés gyakorta kiüresedhet az intézményi és kulturális korlátok folyamán, mikor valós performatív cselekvésre kerülne sor. Ezért az ilyen vezetők gyakorta alkalmaznak tranzaktív vezetést a döntéseket és a célok elérését illetően, míg retorikájukban - szimbolikusan legalábbis - megtartják a kihívásra, a politikai tudásra, a hatalomgyakorlásra, és a követőkre vonatkozó elképzeléseiket. Ezt tapasztaltuk Merkel kapcsán is: retorikai szinten felvette a transzformatív vezetés jellegzetességeit, míg a performatív cselekvésével tranzaktív vezetést írt le. Nem elképzelhetetlen az sem, hogy egy karizmatikus vezetés szimbolikusan transzformatív retorikához nyúljon. Itt azonban a transzformatív kihívás és politikai tudás megjelenését nem eredményezi a követőkkel való viszony átalakulását, amelyre továbbra is a vertikális interakciók, érzelmi kötődés, felhatalmazás és reaktív követői szerep lesz jellemző. Így a követők a vezető személyéhez és bizonyos univerzális értékekhez is kötődhetnek. Ellenkező esetben a tranzaktív vezető - lásd például May vezetését - nem, vagy csak nehezen tud a performatív cselekvést illetően egyik vagy másik irányba elmozdulni. ${ }^{110}$

Harmadrészt a vezetésben rejlő koherencia rugalmas lehet abból a szempontból, hogy az egyes elemek megjelenítését a vezetők végzik el, míg a követők elfogadják azokat. A legnagyobb rugalmasságot a karizmatikus vezetés mutatja. Itt a vezetőnek nagyobb mozgástere van a kihívások értelmezése, valamint a politikai tudás és az alkalmasság bizonyítása kapcsán. Ez a rugalmasság azonban belső bizonytalanságot jelent: nincsenek külső elvek (transzformatív vezetés), valamint intézmények és procedúrák (tranzaktív vezetés), melyekre támaszkodhat a vezető. Mindezt a karizmatikus kapcsolaton kívül esők könnyen veszélyként értelmezhetik. Az ilyen jellegű szabadság leszükül a többi vezetéstípusnál: amíg a transzformatív vezetésnél a célok elérésének

\footnotetext{
${ }^{110}$ Könnyen találhatunk ellenpéldát is erre George W. Bush személyében, aki a 2001-es terrortámadás hatására tranzaktív vezetőből - ha csak időlegesen is - karizmatikussá vált (Bligh, Kohles, és Meindl 2004; Metz 2017a).
} 
módja változhat (konstruktív problémamegoldás és a felhatalmazás megvalósulásának módja), addig a tranzaktív vezetés esetében csak a meglévő eszközök között válogathatnak és a közérdek tartalmát illetően találgathatnak. Ezt a rugalmasságot erősíti az is, hogy nem várható el a vezetőktől, hogy absztrakt fogalmakkal és analitikus pontossággal alkossák meg vezetésképüket. Így bár az értelmezések és lehatárolások tompulhatnak, mégis a vezetéstipológia fényében felismerhetők maradnak.

\subsection{Kitekintés}

Ebben a fejezetben összefoglaltam a kutatásom fontosabb eredményeit és mondanivalóját. Befejezésül, kitekintve a kutatás kereteiből, arra szeretnék kitérni, hogy az eredményeknek van-e tágabb értelemben vett üzenete a demokratikus politikát, $\mathrm{s}$ tágabban a vezetéskutatást és a vezetés politikatudományi vizsgálatát illetően.

Amennyiben elfogadjuk, hogy a vezetés, mint a demokrácia gyakorlata változhat, akkor a demokratikus politika megítélése is nehézkessé és viszonylagossá válhat. A disszertáció értelmezésében a demokrácia és a hozzá köthető intézmények és elvek nem egyszerüen a vezetés kontextusát adják, hanem mint demokratikus gyakorlatok egyszersmind annak eredményét is. Ennek értelmében sem a demokrácia, sem a vezetés tartalma nem adott és csak egymás kölcsönhatásában kristályosodnak ki.

Ennélfogva nem lehet a demokratikus vezetés jellegéből az adott ország egészére vonatkozó kijelentést tenni. Az elemző csupán azt határozhatja meg, hogy egyik vagy másik demokratikus gyakorlat valósul meg, számít dominánsnak vagy érvényesülhet könnyebben az adott politikai közösségben és rendszerben. Mindez azt is jelenti, hogy a demokráciához kötött intézményi és elvi konstelláció csak a vezetők és követők önkéntes kapcsolatában, illetőleg a vezetés aktuális gyakorlatában értelmezhető. Azaz: a vezetés során nyerhetnek értelmet egyes intézmények és procedúrák, illetőleg veszíthetik el jelentőségüket. Ebben a kapcsolatban konstruálódik a demokráciát övező hit, ezzel kialakítva a szereplők elvekhez, intézményekhez és egymáshoz való kötődéseit.

Így az intézmények és elvek csupán terelhetik a demokrácia gyakorlatát és a vezetéssel kapcsolatos elvárásokat. Egyes intézményi, politikai és kulturális kontextusban más és más vezetéstípus érvényesülhet könnyebben. ${ }^{111}$ Történelmi és kulturális tapasztalatból

111 A disszertáció nem térhetett ki az esetek tárgyalása során a különböző politikai és intézményi kontextusokra és azok eltérésére részletesebben. A brit (Elgie 1995, pp. 25-50; Helms 2005, pp. 58-89; 161-90; Peele 2012), a magyar (Körösényi, Hajdú, és Ondré 2015) és német (Elgie 1995, pp. 78-105; Helms 2005, pp. 90-126; 191-124, 2012d) vezetési környezetről lásd bővebben a hivatkozott munkákat. 
fakadóan amíg a német politikában stigmatizáltnak (vö. Helms 2012d), addig a magyar politikában (vö. Körösényi, Hajdú, és Ondré 2015) szinte elvárásnak bizonyul a karizmatikus vezetés. Ez tükröződött Merkel vezetésében, amelyben nem csak az intézményi korlátok miatt nem merülhetett fel karizmatikus válasz a válságra. Söt elvárásként volt értelmezhető a válság morális értelmezése és kezelése is. Ezzel szemben az orbáni vezetés tanulsága szerint a karizmatikus vezetésre való állampolgári igény megvan vagy megteremthető Magyarországon. A brit eset kapcsán is felmerülhet a gyanú, hogy az erős adminisztráció vagy a végrehajtó hatalom kiemelt pozíciója miatt egy jól értelmezett tranzaktív vezetésnek nagyobb esélye van kibontakoznia (vö. Peele 2012). Az előrehozott választások kezdeményezése idején May tranzaktív vezetése még élvezte az állampolgárok többségének bizalmát. Bár Jeremy Corbyn ellenzéki pozícióból heves ellenállás közepette, de érvényesítette transzformatív (mozgalmi) vezetését, mégis az már kérdéses, hogy miniszterelnökként is meg tudta-e volna hitelességét tartani.

A demokrácia gyakorlatát a vezetők és követők együttesen teremtik meg és konstruálják, amely ily módon függ a demokráciával és a demokratikus vezetéssel szemben támasztott elvárásoktól. A vezetők által artikulált demokrácia- és vezetéskép feltárható, azonban a követők értelmezéseivel kapcsolatban csak közvetett információk állnak a rendelkezésünkre. Ennek feltárása azért is problematikus, mert a követők nem csak különbözőképp kapcsolódhatnak vezetőikhez, de még ellentétes percepciókat és elvárásokat is fogalmazhatnak meg. Stephen K. Medvic (2013) várakozási csapdának (expectation trap) nevezi azt a helyzetet, amikor az állampolgárok ellentmondó elvárásokat fogalmaznak meg a vezetőkkel szemben. Elvárják a vezetőktől, hogy kivételes képességekkel rendelkezzenek, morális értelemben kiválóbbak legyenek náluk, de mégis ugyanolyanok legyenek, mint ők. A vezetőknek egyszerre kell szigorúan tartaniuk magukat a közösség meggyőződéseinek és értékeinek a betartásához, és pragmatista módon - kompromisszumokat keresve - feladniuk azokat annak érdekében, hogy megoldják a problémákat. Mindezen túl az állampolgárok azt is kívánják a politikusoktól, hogy legyenek vezetők és használják hatalmukat, amennyiben nem így tesznek a vezetés hiányát (lack of leadership) róják fel számukra, miközben azt is szeretnék, hogy vegyék figyelembe a preferenciájukat, érdekeiket a döntéshozatal során. Azaz: szimultán kell a politikusoknak vezetniük és követniük.

Nem csak az ellentétes, de a túl magas elvárások is problémát jelenthetnek. Ez abban mutatkozik meg, hogy eltérés tapasztalható a között, amit a politikusoknak teljesíteniük 
kellene morális és hatékonysági értelemben, és amire valójában képesek. Ezzel várakozási hézag (expectation gap: Flinders 2012) jön létre. A várakozásokat persze a vezetők is emelik. Meghatározott demokratikus elvek és a közakarat elvárásainak eleget téve olyan ígéreteket tesznek, amelyeket nem képesek betartani. A vezetők több demokráciát és igazságosabb társadalmat kínálnak fel emelve az állampolgári elvárásokat, amely végsősoron a demokrácia sajátos „,pszichológiáját” (Galston 2014) adja.

Mindezt erősíti az a különbség is, amely a politikai teljesítmény közvetlen tapasztalatában és az arról alkotott percepciók közötti eltérésben mutatkozik meg (perception gap: Flinders 2012). Bár az állampolgárok közvetlen tapasztalatai akár pozitívak is lehetnek, mégis az elöítéleteikből, a bizalmatlanságból és a politikaellenes attitüdből fakadóan negatívan ítélhetik meg az adott politikusokat. $\mathrm{S}$ ez fordítva is igaz lehet: a követők a támogatott vezető teljesítményét jobbnak (hatékonyabbnak vagy etikusabbnak) értékelhetik, mint azt mások esetében tennék.

A disszertációkutatás - reményeim szerint - szemléltette, hogy a politikai vezetés formájától és tartalmától függetlenül - megkerülhetetlen a demokratikus politika folyamatában. Erre alapozva két javaslatot fogalmazok meg a további kutatásokat illetően.

Egyfelől nagyobb hangsúlyt kell fektetni a demokratikus vezetési gyakorlatok vizsgálatára. E mögött az a gondolat húzódik meg, hogy a demokráciaelméletek addig a pontig lehetnek érvényesek és hasznosak, ameddig azok visszatükröződni látszanak a demokrácia gyakorlataiban, azaz: ameddig az elméletalkotók konstrukciói összekapcsolódnak a való élet politikai szereplőivel. Így az elmélet és empíria között tátongó szakadék áthidalható anélkül, hogy a két kutatási irány intellektuális gazdagságát és eredményeit elvesztenénk vagy csorbítanánk. Ez azért is fontos, mert a demokratikus vezetéstipológia fényében értelmezhetővé válhat a demokráciában megmutatkozó dinamika (realignment/dealignment), de a kudarcok és a változások is. Így a tipológia által nyújtott plurális olvasattal el lehet kerülni, hogy a kutató szélesítse és erősítse a szakirodalmat uraló válságdiskurzust (ld. erről: Ercan és Gagnon 2014; Flinders 2016; W. Merkel 2014). Hiszen amíg egyik szemszögből a vezetés a demokrácia beteljesülését, addig egy másikból annak ellehetetlenülését jelenítheti meg.

Másfelől ehhez kapcsolódóan fontos pontosabb képet kapni a követők és az állampolgárok demokráciát és vezetést illető elképzeléseiről. A kérdés néhány kutatás (ld. például a romance of leadership elméletét: Meindl, Ehrlich, és Dukerich 1985; 
Bligh, Kohles, és Meindl 2004) kivételétől eltekintve, a politikatudományban nem kap kellő figyelmet annak ellenére, hogy a multidiszciplináris vezetéskutatásban egyre nagyobb teret nyer (Uhl-Bien és mtsai. 2014). Ez persze önmagában nem elégséges, hiszen a vezetők alkotási tevékenységet nem lehet kivenni a folyamatból. Azonban amennyiben a követők oldaláról is nagyobb mélységben feltárhatóvá válik a vezetés dinamikája, akkor teljesebb képet kaphatunk a demokrácia gyakorlatának egészéröl és arról, hogy az állampolgárok miként kívánnak ahhoz csatlakozni. Ezzel elkerülhető annak a vádja, hogy a politikai folyamatokon kívül és az állampolgároktól távol eső elveket kívánunk érvényesíteni a demokrácia és a vezetés megítélése kapcsán.

Összességében a demokrácia és a vezetés kapcsolata számos választás és kérdés elé állítja mind a kutatókat, mind a politikai szereplőket egyformán. Ezekre nincs univerzálisan helyes és érvényes megoldás, azonban fontos tudatában lenni annak a disszertációban feltárt és alkalmazott fogalmi hálónak, amely áthatja és lefedi a demokratikus vezetés problémáját. Ehhez - Albert Rothenberg gondolatát idézve olyan ,janusi gondolkodásra” (Janusian thinking) van szükség, amelyben képesek vagyunk „két vagy több ellentétesnek vagy ellentmondásosnak tünő ötletet, koncepciót és képet egyszerre elképzelni és hasznosítani” (ford. tőlem) (Rothenberg 1971, p. 195). A rothenbergi elméletben ezen alapul a kreatív gondolkodás és maga az alkotó tevékenység. Ebben segíthet a disszertáció által kialakított és alkalmazott plurális olvasat, amely átfogja és feloldja a demokratikus vezetés problémáját elméleti és gyakorlati szinten egyaránt. 


\section{BIBLIOGRÁFIA}

Achen, Christopher H., és Larry M. Bartels (2016): Democracy for realists: why elections do not produce responsive government. Princeton: Princeton University Press.

Allen, Nicholas (2017): „Brexit, Butchery and Boris: Theresa May and Her First Cabinet”. Parliamentary Affairs 70(3): 633-44. https://doi.org/10.15203/ozp.1587.vol46iss1

Antonakis, John (2018): „Charisma and the "New Leadership””. In The nature of leadership, John Antonakis és David V. Day (szerk.) Los Angeles: SAGE Publications, Inc, 56-81.

Antonakis, John, Nicolas Bastardoz, Philippe Jacquart, és Boas Shamir (2016): „Charisma: An Ill-Defined and Ill-Measured Gift”. Annual Review of Organizational Psychology and Organizational Behavior 3(1): 293-319. https://doi.org/10.1146/annurev-orgpsych$\underline{041015-062305}$

Arisztotelész (1984): Politika. Budapest: Gondolat. (1987): Nikomakhoszi etika. Budapest: Európa Kiadó. (1992): Metafizika. Budapest: Hatágú Síp Alapítvány.

Árpási, Botond Gergely. (2018): „Devulóció és Brexit: Politikai vezetés és történetalkotás a vezérdemokrácia tükrében". Politikatudományi Szemle 27(3): 102-29.

Asthana, Anushka, Heather Stewart, és Rankin Jennifer (2017): „Juncker will find me »bloody difficult woman « in Brexit talks, says May". The Guardian. https://www.theguardian.com/politics/2017/may/02/may-juncker-will-find-me-bloodydifficult-woman-in-brexit-talks (2018. március 27.).

Aurelius, Marcus (1983): Marcus Aurelius elmélkedései. Budapest: Európa Könyvkiadó.

Babcock, Barbara Allen, és Ticien Marie Sassoubre (2007): „Deliberation in 12 Angry Men”. Chicago-Kent Law Review 83: 633-42. https://law.stanford.edu/publications/deliberationin-12-angry-men (2018. március 27.).

Bächtiger, André és mtsai. (2010): „Disentangling Diversity in Deliberative Democracy: Competing Theories, Their Blind Spots and Complementarities*". Journal of Political Philosophy 18(1): 32-63. https://doi.org/10.1111/j.1467-9760.2009.00342.x

Bagdonas, Azuolas (2015): „The EU Migration Crisis and the Baltic Security”. Journal on Baltic Security 1.(2.): 7-27. https://doi.org/10.1515/jobs-2016-0019

Balázs, Zoltán (1998): Modern hatalomelméletek. Budapest: Korona. (2003): „Hatalom”. In A politikai közösség, Osiris könyvek, Budapest: Osiris, 113-142.

Bale, Tim, és Paul Webb (2017) „'Honey, I Shrunk the Majority': Theresa May and the Tories”. Political Insight 8(2): 20-23. https://doi.org/10.1177/2041905817726900

Balzacq, Thierry, Sarah Léonard, és Jan Ruzicka (2016): „'Securitization’ Revisited: Theory and Cases". International Relations 30(4): 494-531. https://doi.org/10.1177/0047117815596590

BAMF (2016a): Aktuelle Zahlen zu Asyl. Bundesamt für Migration und Flüchtlinge. http://www.bamf.de/SharedDocs/Anlagen/DE/Downloads/Infothek/Statistik/Asyl/aktuell e-zahlen-zu-asyl-dezember-2016.pdf? blob=publicationFile (2018. május 5.).

(2016b): Migration, Integration, Asylum Political Developments in Germany 2015 (Annual Policy Riport). Bundesamt für Migration und Flüchtlinge (Federal Office for Migration and

Refugees). https://www.bamf.de/SharedDocs/Anlagen/EN/Publikationen/EMN/Politikberichte/emnpolitikbericht-2015-germany.pdf?_blob=publicationFile (2018. május 5.).

(2017): Migration, Integration, Asylum Political Developments in Germany 2016 (Annual Policy Riport). Bundesamt für Migration und Flüchtlinge (Federal Office for Migration and

Refugees). 
http://www.bamf.de/SharedDocs/Anlagen/EN/Publikationen/EMN/Politikberichte/emnpolitikbericht-2016-germany.pdf?_blob=publicationFile (2018. május 5.).

Banaji, Shakuntala (2017): „Young People and Propaganda in the Wake of the 2017 Election”. In UK Election Analysis 2017: Media, Voters and the Campaign, Einar Thorsen, Daniel Jackson, és Darren G Lilleker (szerk.). Poole, England: The Centre for the Study of Journalism, Culture and Community Bournemouth University, 24.

Barber, Benjamin R. (1989): „Neither Leaders Nor Followers: Citizenship Under Strong Democracy". In Essays in honor of James MacGregor Burns, Michael R. Beschloss és Thomas E. Cronin (szerk.). Englewood Cliffs, N.J: Prentice Hall, 117-27.

(2004): Strong Democracy: Participatory Politics for a New Age. 20. anniversary ed., with a new preface. Berkeley: University of California Press.

Barber, James David (1972): The Presidential Character: Predicting Performance in the White House. 1st paperback ed. Englewood Cliffs, NJ: Prentice-Hall.

Barge, J. Kevin, és Gail T. Fairhurst (2008): „Living Leadership: A Systemic Constructionist Approach". Leadership 4(3): 227-51. https://doi.org/10.1177/1742715008092360

Bass, Bernard M. (2008): The Bass handbook of leadership: theory, research, and managerial applications. 4th ed., New York: Free Press.

Bass, Bernard M., és Paul Steidlmeier (1999): „Ethics, character, and authentic transformational leadership behavior". Leadership Quarterly 10(2): 181-217. https://doi.org/10.1016/S1048-9843(99)00016-8

Battegazzorre, Francesco (2017): „Some Reflections on the »Power to«/"power over" Debate”. Journal of Political Power 10(3): 274-85. https://doi.org/10.1080/2158379X.2017.1382169

Beerbohm, Eric (2015): „Is Democratic Leadership Possible?” American Political Science Review 109(4): 639-52. https://doi.org/10.1017/S0003055415000398

Bennis, Warren G. (1999): „The End of Leadership: Exemplary Leadership is Impossible Without the Full Inclusion, Initiatives, and Cooperation of Followers". Organnnizational Dynamics 28(1): 71-80. http://dx.doi.org/10.1016/S0090-2616(00)80008-X

Bennis, Warren G., és Burt Nanus (1985): Leaders: The Strategies for Taking Charge. New York: Harper \& Row.

Bennister, Mark, és Ben Worthy (2016): „Why is real leadership in such short supply in UK politics?" LSE British Politics and Policy Blog. ühttp://blogs.lse.ac.uk/politicsandpolicy/why-is-political-leadership-in-such-short-supply/ (2018. május 5.).

Bennister, Mark, Ben Worthy, és Dan Keith (2017): „Jeremy Corbyn and the Limits of Authentic Rhetoric". In Voices of the UK Left, Rhetoric, Politics and Society, Judi Atkins és John Gaffney (szerk.). Palgrave Macmillan, Cham, 101-21.

Bessette, Joseph M. (1980): „Deliberative Democracy: The Majority Principle in Republican Government". In How democratic is the Constitution?, Robert A. Goldwin és William A. Schambra (szerk.). Washington, D.C: American Enterprise Institute for Public Policy Research, 102-116.

Bligh, Michelle C, Jeffrey C Kohles, és James R Meindl (2004): „Charisma under crisis: Presidential leadership, rhetoric, and media responses before and after the September 11th terrorist attacks". The Leadership Quarterly 15(2): 211-39. https://doi.org/10.1016/j.leaqua.2004.02.005

Blondel, Jean (1987): Political leadership: towards a general analysis. London; Beverly Hills: Sage Publications.

(2018): „Elites or Leadership? Opposite or Complementary Paradigms?” In The Palgrave handbook of political elites, Palgrave Handbooks, Heinrich Best és John Higley (szerk.) London, United Kingdom: Palgrave Macmillan imprint is published by Springer Nature, 625-42.

Boda, Zsolt (2013): „Politikai vezetés és kollektív cselekvés”. Politikatudományi Szemle 22(2): 73-89. 
Boswell, Christina (2000): „European Values and the Asylum Crisis”. International Affairs 76(3): 537-57. https://doi.org/10.1111/1468-2346.00150

Boyatzis, Richard E. (1998): Transforming qualitative information: thematic analysis and code development. Thousand Oaks, CA: Sage Publications.

Brooker, Paul (2010): Leadership in Democracy. Houndmills, Basingstoke, Hampshire; New York: Palgrave Macmillan.

Brown, Archie (2014): The myth of the strong leader: political leadership in modern politics. New York: Basic Books.

- (2016): „Against the Führerprinzip: For Collective Leadership”. Daedalus 145(3): 10923. https://doi.org/10.1162/DAED_a_00401

Brunner, Otto, Werner Conze, és Reinhart Koselleck (1999): A demokrácia. Budapest: Jószöveg Mühely K.

Burns, James MacGregor (1978): Leadership. 1st ed. New York: Harper \& Row. (2003): Transforming Leadership: A New Pursuit of Happiness. New York: Grove Press.

Cammaerts, Bart, Brooks DeCillia, João Carlos Magalhães, és Cesar Jimenez-Martinez (2016): Journalistic Representations of Jeremy Corbyn in the British Press From , Watchdog” to „Attackdog”. London School Of Economy.

Canovan, Margaret (1999): „Trust the People! Populism and the Two Faces of Democracy”. Political Studies 47(1): 2-16. https://doi.org/10.1111/1467-9248.00184

Chadwick, Andrew (2017): „Corbyn, Labour, Digital Media, and the 2017 UK Election”. In UK Election Analysis 2017: Media, Voters and the Campaign, Einar Thorsen, Daniel Jackson, és Darren G Lilleker (szerk.). Poole, England: The Centre for the Study of Journalism, Culture and Community Bournemouth University, 89.

Ciulla, Joanne B. (2014a): „Leadership and the Problem of Bogus Empowerment”. In Ethics, the Heart of Leadership, 3rd Edition, Joanne B. Ciulla (szerk.). ABC-CLIO, 59-82.

(2014b): „Leadership Ethics: Expanding the Territory”. In Ethics, the Heart of Leadership, 3rd Edition, Joanne B. Ciulla (szerk.). ABC-CLIO, 3-31.

(2018): „Ethics Effectiveness: The Nature of Good Leadership”. In The nature of leadership, John Antonakis és David V. Day (szerk.) Los Angeles: SAGE Publications, Inc, 438-468.

Ciulla, Joanne B., és Donelson R. Forsyth (2011): „Leadership ethics”. In The SAGE handbook of leadership, Alan Bryman és mtsai. (szerk.) London; Thousand Oaks, Calif: SAGE, 229-241.

Cohen, Joshua (1997): „Deliberation and Democratic Legitimacy”. In Deliberative democracy: essays on reason and politics, James Bohman és William Rehg (szerk.). Cambridge, Mass: MIT Press, 67-91.

Cohen, Stanley (2011): Folk devils and moral panics: the creation of the Mods and Rockers. Abingdon, Oxon; New York: Routledge.

Collier, David, Fernando Daniel Hidalgo, és Andra Olivia Maciuceanu (2006): „EssentiallyContested Concepts: Debates and Applications”. Journal of Political Ideologies 11(3): 211-46. https://doi.org/10.1080/13569310600923782

Collier, David, és Steven Levitsky (1997): „Democracy with Adjectives: Conceptual Innovation in Comparative Research". World Politics 49(3): 430-51. https://doi.org/10.1353/wp.1997.0009

Collinson, David (2014): „Dichotomies, Dialectics and Dilemmas: New Directions for Critical Leadership Studies?” Leadership 10(1): 36-55. https://doi.org/10.1177/1742715013510807

Collinson, David, és Keith Grint (2005): „Editorial: The Leadership Agenda”. Leadership 1(1): 5-9. https://doi.org/10.1177/1742715005049346

Corbyn, Jeremy (2015): „Speech to Labour Party Conference”. http://www.ukpol.co.uk/1795/ (2018. március 26.). 
(2016a): „My speech at Annual Conference in Liverpool 2016”. http://jeremycorbyn.org.uk/articles/jeremy-corbyn-my-speech-at-annual-conference-inliverpool-2016/ (2018. március 26.).

(2016b): „My speech at the launch of the Chakrabarti report”. http://jeremycorbyn.org.uk/articles/jeremy-corbyn-my-speech-at-the-launch-of-thechakrabarti-report/ (2018. március 26.).

(2016c): „My speech on the result of the EU referendum". http://jeremycorbyn.org.uk/articles/jeremy-corbyn-my-speech-on-the-result-of-the-eureferendum/ (2018. március 26.).

(2016d): „My speech to the Party of European Socialists Council in Prague”. http://jeremycorbyn.org.uk/articles/jeremy-corbyn-my-speech-to-the-party-of-europeansocialists-council-in-prague/ (2018. március 26.).

(2016e): „Statement on No Confidence Vote”. http://www.ukpol.co.uk/jeremy-corbyn2016-statement-on-no-confidence-vote/ (2018. március 26.).

(2017a): „First peech of the 2017 General Election campaign”. http://uk.businessinsider.com/jeremy-corbyn-labour-party-general-election-campaignlaunch-speech-in-full-2017-5 (2018. március 26.).

(2017b): „My speech to National Policy Forum”. http://jeremycorbyn.org.uk/articles/jeremy-corbyn-my-speech-to-national-policy-forum/ (2018. március 26.).

(2017c): „Speech at Labour’s campaign launch”. http://uk.businessinsider.com/jeremycorbyn-labour-party-general-election-campaign-launch-speech-in-full-2017-5 (2018. március 26.).

(2017d): "Statement to the House on the triggering of Article 50". https://labour.org.uk/press/jeremy-corbyn-statement-to-the-house-on-the/ (2018. március 26.).

(2017e): „Stepping up for Britain”. https://labour.org.uk/press/jeremy-corbyn-speechstepping-up-for-britain/ (2018. március 26.).

Corwin, R. G. (1978): „Power”. In Sociology: The basic concepts, E. Sagarin (szerk.) New York: Holt, Rinehart \& Winston.

Crevani, Lucia, Johann Packendorff, és Monica Lindgren (2007): „Shared leadership: A postheroic perspective on leadership as a collective construction". International Journal of Leadership Studies 3(1): 40-67.

Crines, Andrew (2015): „Reforming Labour: The Leadership of Jeremy Corbyn”. Political Insight 6(3): 4-7. https://doi.org/10.1111/2041-9066.12105

(2017a): „Rhetoric of the 2017 General Election Campaign”. In UK Election Analysis 2017: Media, Voters and the Campaign, Einar Thorsen, Daniel Jackson, és Darren G Lilleker (szerk.) Poole, England: The Centre for the Study of Journalism, Culture and Community Bournemouth University, 74.

(2017b): „Transforming Labour: The 'New' Labour Leadership of Jeremy Corbyn”. Political Insight 8(2): 26-29. https://doi.org/10.1177/2041905817726903

Cronin, Thomas E., és Michael A. Genovese (2012): Leadership matters: unleashing the power of paradox. Boulder, CO: Paradigm Publishers.

Cross, Mai'a K. Davis, és Xinru Ma (2015): „EU crises and integrational panic: the role of the media". Journal of European Public Policy 22(8): 1053-70. https://doi.org/10.1080/13501763.2014.984748

Cunningham, Frank (2002): Theories of Democracy: A Critical Introduction. London; New York: Routledge.

Csizmadia, Ervin (2006a): „Politikai vezetők és politikai környezet. I. Miniszterelnöki változásmodellek Európában és Magyarországon”. Politikatudományi Szemle 15(2-3.): 25-52.

(2006b): „Politikai vezetők és politikai környezet. II. Magyar miniszterelnökök egy változáselmélet tükrében”. Politikatudományi Szemle 15(4): 5-40. 
Dahl, Robert A. (1956): A preface to democratic theory. Chicago: University of Chicago Press. (1957): „The Concept of Power”. Behavioral Science 2(3): 201-15.

(1961): Who governs? : democracy and power in an American city. New Haven: Yale University Press.

(1971): Polyarchy: Participation and Opposition. New Haven: Yale Univ. Press.

(1989): Democracy and Its Critics. New Haven: Yale University Press.

Dahl, Robert A., és C.E. Lindblom (1953): Politics, Economics, and Welfare. New Haven: Yale University Press.

Deacon, David és mtsai. (2017): „A Tale of Two Leaders: New Media Coverage of the 2017 General Election". In UK Election Analysis 2017: Media, Voters and the Campaign, Einar Thorsen, Daniel Jackson, és Darren G Lilleker (szerk.) Poole, England: The Centre for the Study of Journalism, Culture and Community Bournemouth University, 40-41.

Deneen, Patrick J. (2005): Democratic faith. Princeton, N.J: Princeton University Press.

Der Spiegel (2015): „Mother Angela. Merkel's Refugee Policy Divides Europe”. Der Spiegel. http://www.spiegel.de/international/germany/refugee-policy-of-chancellor-merkeldivides-europe-a-1053603.html (2018. május 7.).

Dessewffy, Tibor, és Bence Ságvári (2014): „Dzsingisz kán a parlamentben. Közveszélyes vezetõk: Mao és Jim Jones”. Mozgó Világ 40(2-3.): 177-192.

Deutsche Welle (2016): „Germans becoming increasingly xenophobic, study finds". http://www.dw.com/en/germans-becoming-increasingly-xenophobic-study-finds/a19332024 (2018. május 22.).

Diamond, Patrick (2016): „Assessing the Performance of UK Opposition Leaders: Jeremy Corbyn's 'Straight Talking, Honest Politics"'. Politics and Governance 4(2): 15-24. http://dx.doi.org/10.17645/pag.v4i2.567

Die Welt (2010): „Integration: Kanzlerin Merkel erklärt Multikulti für gescheitert”. Die Welt. https://www.welt.de/politik/deutschland/article10337575/Kanzlerin-Merkel-erklaertMultikulti-fuer-gescheitert.html (2018. május 18.).

Dorey, Pete (2017): „A Tale of Two Leadership Campaigns”. In UK Election Analysis 2017: Media, Voters and the Campaign, Einar Thorsen, Daniel Jackson, és Darren G Lilleker (szerk.) Poole, England: The Centre for the Study of Journalism, Culture and Community Bournemouth University, 123.

Downs, Anthony (1957): An Economic Theory of Democracy. New York: Harper \& Row. (1962): „The Public Interest. Its Meaning in a Democracy”. Social Research 29(1): 136.

(1994): Inside Bureaucracy. Reissued 1994. Prospect Heights, IL: Waveland Press.

Downton, James V. (1973): Rebel Leadership: Commitment and Charisma in the Revolutionary Process. New York: Free Press

Dryzek, John S. (2002): Deliberative democracy and beyond: liberals, critics, contestations. Oxford: Oxford University Press.

Duncombe, Stephen (2007): Dream: re-imagining progressive politics in an age of fantasy. New York: New Press ; Distributed by W.W. Norton.

(2012): „Politics as Art of the Impossible: The Case for a Dreampolitik in the United States". Café Philosophy. http://cafephilosophy.co.nz/articles/art-of-the-impossible/. (2018. május 18.).

Dunleavy, Patrick (2017): „How 'groupthink' in Theresa May's Downing Street delivered another round of UK political chaos". LSE British Politics and Policy Blog. http://blogs.lse.ac.uk/politicsandpolicy/how-groupthink-in-theresa-mays-downing-streetdelivered-another-round-of-uk-political-chaos/ (2017. július 18.).

Edinger, Lewis J. (1967): „Editor's introduction”. In Political leadership in industrialized societies, Lewis J. Edinger (szerk.) New York: Wiley, 1-25.

(1975): „The Comparative Analysis of Political Leadership”. Comparative Politics 7(2): 253-269. 
(1993): „A Preface to Studies in Political Leadership”. In Innovative leaders in international politics, SUNY series in leadership studies, Gabriel Sheffer (szerk.) Albany: State University of New York Press.

Elgie, Robert (1995): Political Leadership in Liberal Democracies. Houndsmills: Palgrave Macmillan.

(2015): Studying political leadership: foundations and contending accounts. Houndmills, Basingstoke, Hampshire: Palgrave Macmillan.

(2018): Political leadership: a pragmatic institutionalist approach. London: Palgrave Macmillan.

Elster, Jon (1997): „The Market and the Forum: Three Varieties of Political Theory”. In Deliberative democracy: essays on reason and politics, James Bohman és William Rehg (szerk.) Cambridge, Mass: MIT Press, 3-35.

Elstub, Stephen (2010): „The Third Generation of Deliberative Democracy”. Political Studies Review 8(3): 291-307. https://doi.org/10.1111/j.1478-9302.2010.00216.x

Emerson, Ralph Waldo (1844): „The Poet”. In Essays: Second Series, Boston: James Munroe and Company, 3-49.

Enyedi, Zsolt (2005): „The Role of Agency in Cleavage Formation”. European Journal of Political Research 44(5): 697-720. https://doi.org/10.1111/j.1475-6765.2005.00244.x

Ercan, Selen A., és Jean-Paul Gagnon (2014): „The Crisis of Democracy: Which Crisis? Which Democracy?" Democratic Theory 1(2): 1-10. https://doi.org/10.3167/dt.2014.010201

European Commission (2015a) „EU Action Plan against migrant smuggling (2015-2020).” http://ec.europa.eu/anti-

trafficking/sites/antitrafficking/files/eu_action_plan_against_migrant_smuggling_en.pdf (2018. május 7.).

(2015b): „Standard Eurobarometer 83. (Spring 2015)”. http://ec.europa.eu/COMMFrontOffice/publicopinion/index.cfm (2018. május 8.).

(2015c): „Standard Eurobarometer $84 . \quad$ (Autumn 2015)". http://ec.europa.eu/COMMFrontOffice/publicopinion/index.cfm (2018. május 8.).

(2016a): Asylum in the EU Member States: Record number of over 1.2 million first time asylum seekers registered in $2015 . \quad$ Eurostat. http://ec.europa.eu/eurostat/documents/2995521/7203832/3-04032016-AP-

EN.pdf/790eba01-381c-4163-bcd2-a54959b99ed6 (2018. május 6.).

(2016b): Sixth report on relocation and resettlement. Brussels: European Commission. https://ec.europa.eu/home-affairs/sites/homeaffairs/files/what-we-do/policies/europeanagenda-migration/proposal-implementation-

package/docs/20160928/sixth_report_on_relocation_and_resettlement_en.pdf $\quad$ (2018. május 6.).

(2016c): „Standard Eurobarometer 85. (Spring 2016)”. http://ec.europa.eu/COMMFrontOffice/publicopinion/index.cfm (2018. május 8.).

(2016d): „Standard Eurobarometer 86. (Autumn 2016)”. http://ec.europa.eu/COMMFrontOffice/publicopinion/index.cfm (2018. május 8.).

(2017): Asylum in the EU Member States: 1.2 million first time asylum seekers registered in 2016. Eurostat. http://ec.europa.eu/eurostat/documents/2995521/7921609/316032017-BP-EN.pdf/e5fa98bb-5d9d-4297-9168-d07c67d1c9e1 (2018. május 6.).

European Parliament (2017): EU migrant crisis: facts and figures. European Parliament. http://www.europarl.europa.eu/news/en/headlines/society/20170629STO78630/eumigrant-crisis-facts-and-figures (2018. május 7.).

Fairhurst, Gail T., és David Grant (2010): „The Social Construction of Leadership: A Sailing Guide". Management Communication Quarterly 24(2): 171-210. https://doi.org/10.1177/0893318909359697

Felten, Eric (2016) „Citizen Trump?” Weekly Standard. https://www.weeklystandard.com/ericfelten/citizen-trump (2018. február 6.). 
Femia, Joseph (2009): „Elites. vs. the. Popular. Will. A False Dichotomy”. In Political Leadership in Liberal and Democratic Theory, András Körösényi, Joseph Femia, és Gabriella Slomp (szerk.) Exeter: Imprint Academic, 67-78.

Fischbein, Rebecca, és Robert G. Lord (2004): „Implicit Leadership Theories” George R. Goethals, Georgia Jones Sorenson, és James MacGregor Burns (szerk.) Encyclopedia of leadership 2: 700-705.

Fishkin, James S. (2009): When the people speak: deliberative democracy and public consultation. Oxford ; New York: Oxford University Press.

Fletcher, Joyce K. (2004): „The paradox of postheroic leadership: An essay on gender, power, and transformational change". The Leadership Quarterly 15(5): 647-61. https://doi.org/10.1016/j.leaqua.2004.07.004

Flinders, Matthew (2012) Defending politics: why democracy matters in the twenty-first century. Oxford; New York: Oxford University Press.

(2016): „The Problem with Democracy”. Parliamentary Affairs 69(1): 181-203. https://doi.org/10.1093/pa/gsv008

Flinders, Matthew, és Matthew Wood (2015): „From Folk Devils to Folk Heroes: Rethinking the Theory of Moral Panics". Deviant Behavior 36(8): 640-56. https://doi.org/10.1080/01639625.2014.951579

Foley, Michael (2013): Political leadership: themes, contexts, and critiques. Oxford, United Kingdom; New York: Oxford University Press.

Follett, Mary Parker (1930): Creative Experience. London: Longmans, Green and Co. (1942a): „Construcitve Conflict”. In Dynamic Administration: The Collected Papers of Mary Parker Follett, Henry C Metcalf és Lyndall F Urwick (szerk.) New York, London: Harper and Brothers Publishers, 1-22.

(1942b): „Power”. In Dynamic Administration: The Collected Papers of Mary Parker Follett, Henry C Metcalf és Lyndall F Urwick (szerk.) New York, London: Harper and Brothers Publishers, 72-95.

(1942c): „The Giving of Orders”. In Dynamic Administration: The Collected Papers of Mary Parker Follett, Henry C Metcalf és Lyndall F Urwick (szerk.) New York, London: Harper and Brothers Publishers, 23-45.

Frontex (2015): „Western Balkans Risk Analysis Network Quarterly Report (Q4 2015)”. http://frontex.europa.eu/assets/Publications/Risk Analysis/WB Q4 2015.pdf február 19.).

Gaffney, John (2016): „Labour's century-old problem: leadership performance”. British Politics and Policy at LSE. http://blogs.lse.ac.uk/politicsandpolicy/labours-century-old-problemthe-politics-of-leadership-performance/. (2018. május 8.).

Gagnon, Jean-Paul, Mark Chou, Selen Ercan, és Giovanni Navarria (2014): „Democratic Theories Database. Five Hundred and Seven Theories of Democracy". Database for Working Paper \#1, Australian Catholic University Research Node in the Sydney Democracy Network. http://sydneydemocracynetwork.org/wpcontent/uploads/2014/11/Democratic-Theories-Database.pdf. (2018. május 8.).

Gallie, W. B. (1955): „Essentially Contested Concepts”. Proceedings of the Aristotelian Society 56: $167-98$.

Galston, William A. (2014): „Populist Resentment, Elitist Arrogance: Two Challenges to Good Democratic Leadership". In Good democratic leadership: on prudence and judgment in modern democracies, John Kane és Haig Patapan (szerk.) Oxford, United Kingdom; New York, NY: Oxford University Press, 15-31.

Gardner, Howard (2011): Leading minds: an anatomy of leadership. New York, NY: BasicBooks.

Gardner, John W. (1990): On Leadership. New York; Toronto: Free Press ; Maxwell Macmillan

Gardner, William L., Claudia C. Cogliser, Kelly M. Davis, és Matthew P. Dickens (2011): „Authentic leadership: A review of the literature and research agenda". The Leadership Quarterly 22(6): 1120-45. https://doi.org/10.1016/j.leaqua.2011.09.007 
Gastil, John (1994): „A Definition and Illustration of Democratic Leadership”. Human Relations 47(8): 953-75. https://doi.org/10.1177/001872679404700805

Gibbs, Nancy (2015) „The Choice”. TIME magazine. http://time.com/time-person-of-the-year2015-angela-merkel-choice/ (2018. május 5.).

Gifford, Chris (2017): „Brexit without Brexitland”. In UK Election Analysis 2017: Media, Voters and the Campaign, Einar Thorsen, Daniel Jackson, és Darren G Lilleker (szerk.) Poole, England: The Centre for the Study of Journalism, Culture and Community Bournemouth University, 113.

Goodin, Robert E. (2005): „Sequencing Deliberative Moments”. Acta Politica 40(2): 182-96. https://doi.org/10.1057/palgrave.ap.5500098

(2008.) Innovating democracy: democratic theory and practice after the deliberative turn. Oxford; New York: Oxford University Press.

- (szerk.) (2011): The Oxford handbook of political science. Oxford: Oxford Univ. Pr. https://doi.org/10.1177/2041905817744605

Goodlad, Graham (2017):. „Theresa May: A Premiership in Crisis”. Political Insight 8(3): 8-11.

Gouldner, Alvin W. (szerk.) (1950): Studies in Leadership: Leadership and Democratic Action. 1 st edition. New York: Harper and Brothers.

Green, Jeffrey E. (2010): The eyes of the people: democracy in an age of spectatorship. Oxford; New York: Oxford University Press.

Greenleaf, Robert K. (1977): Servant leadership: a journey into the nature of legitimate power and greatness. New York: Paulist Press.

Grimm, Jacob, és Wilhelm Grimm (1999): Deutsches Wörterbuch. München: Deutscher Taschenbuch Verlag.

Grinin, Leonid (2010): „The Role of an Individual in History: A Reconsideration”. Social Evolution \& History 9(2): 95-136. http://dx.doi.org/10.2139/ssrn.1752886

Grint, Keith (2001): The Arts of Leadership. Oxford: Oxford University Press. (2005a): Leadership: Limits and Possibilities. Houndmills, Basingstoke, Hampshire; New York, N.Y: Palgrave Macmillan.

(2005b): „Problems, Problems, Problems: The Social Construction of »Leadership «”. Human Relations 58(11): 1467-94. https://doi.org/10.1177/0018726705061314

(2010): „The Sacred in Leadership: Separation, Sacrifice and Silence”. Organization Studies 31(1): 89-107. https://doi.org/10.1177/0170840609347054

(2014): „Social-Constructionist Analysis”. In The Oxford Handbook of Political Leadership, R. A. W. Rhodes és Paul 't Hart (szerk.) Oxford Handbooks in Politics \& International Relations.

(2016): „Dirty Hands and Clean Heels: 21 Days of Political Leadership in the UK”. Leadership 12(5): 564-80. https://doi.org/10.1177/1742715016669477

Gronn, Peter (2002): „Distributed leadership as a unit of analysis”. The Leadership Quarterly 13(4): 423-51. https://doi.org/10.1016/S1048-9843(02)00120-0

Gutmann, Amy, és Dennis Thompson (1996): Democracy and disagreement. Cambridge, Mass: Belknap Press of Harvard University Press.

(2004): Why deliberative democracy? Princeton, N.J: Princeton University Press.

Habermas, Jürgen (1996a): Between Facts and Norms: Contributions to a Discourse Theory of Law and Democracy. Cambridge, Mass: MIT Press.

(1996b): „Three Normative Models of Democracy”. In Democracy and difference: contesting the boundaries of the political, Princeton paperbacks, Seyla Benhabib (szerk.) Princeton, N.J: Princeton University Press, 21-30.

Hargrove, Erwin C. (2004): „History, Political Science and the Study of Leadership”. Polity 36(4): 579-93. https://doi.org/10.1086/POLv36n4ms3235403 
't Hart, Paul, és R. A. W. Rhodes (2014): „Puzzles of Political Leadership”. In The Oxford Handbook of Political Leadership, R. A. W. Rhodes és Paul 't Hart (szerk.) Oxford University Press.

Hay, Colin (2002): Political analysis. Houndmills, Basingstoke, Hampshire; New York: Palgrave.

Heath, Oliver, és Matthew Goodwin (2017): „The 2017 General Election, Brexit and the Return to Two-Party Politics: An Aggregate-Level Analysis of the Result". The Political Quarterly 88(3): 345-58. https://doi.org/10.1111/1467-923X.12405

Heifetz, Ronald A. (1994): Leadership without easy answers. Cambridge, Mass: Belknap Press of Harvard University Press.

Helms, Ludger (2005): Presidents, prime ministers, and chancellors: executive leadership in western democracies. Houndmills, Basingstoke, Hampshire; New York: Palgrave Macmillan.

- (2012a): „Beyond the Great and Glorious: Researching Poor Leadership and Bad Governance in Liberal Democracies". Zeitschrift für Staats- und Europawissenschaften / Journal of Comparative Government and European Policy 10: 492-509. https://doi.org/10.5771/1610-7780-2012-4-492

(szerk.) (2012b): Comparative political leadership. Houndmills, Basingstoke, Hampshire ; New York: Palgrave Macmillan.

(2012c): „Democratic Political Leadership in the New Media Age: A Farewell to Excellence?" The British Journal of Politics \& International Relations 14(4): 651-70. https://doi.org/10.1111/j.1467-856X.2011.00495.x

(2012d): „Revisiting the German chancellorship: leadership weakness and democratic autocracy in the Federal Republic". In Poor leadership and bad governance: reassessing presidents and prime ministers in North America, Europe and Japan, New horizons in leadership studies, Ludger Helms (szerk.) Cheltenham; Northampton, Mass: Edward Elgar, 110-29.

(2014): „When the Leaders are Not Good: Exploring Bad Leaderhip in Liberal Democracies across Time and Space". In Good democratic leadership: on prudence and judgment in modern democracies, John Kane és Haig Patapan (szerk.) Oxford, United Kingdom; New York, NY: Oxford University Press, 51-70.

Helms, Ludger, és Femke Van Esch (2017): „Turning Structural Weakness into Personal Strength Angela Merkel and the Politics of Leadership Capital in Germany". In The Leadership Capital Index: a new perspective on political leadership, Mark Bennister, Ben Worthy, és Paul 't Hart (szerk.) Oxford; New York, NY: Oxford University Press, 27-44.

Helms, Ludger, Femke Van Esch, és Beverly Crawford (2018): „Merkel III: From Committed Pragmatist to 'Conviction Leader'?' German Politics: 1-21. https://doi.org/10.1080/09644008.2018.1462340

Henn, Matt, és James Hart (2017): „The Generation Election: Youth Electoral Mobilisation at He 2017 General Election". In UK Election Analysis 2017: Media, Voters and the Campaign, Einar Thorsen, Daniel Jackson, és Darren G Lilleker (szerk.) Poole, England: The Centre for the Study of Journalism, Culture and Community Bournemouth University, 25.

Hirschman, Albert O. (1970): Exit, voice, and loyalty: responses to decline in firms, organizations, and states. Cambridge, Mass: Harvard University Press.

(1985): Shifting Involvements: Private Interest and Public Action. Oxford: Blackwell.

Holmes, Seth M., és Heide Castañeda (2016): „Representing the "European refugee crisis” in Germany and beyond: Deservingness and difference, life and death". American Ethnologist 43(1): 12-24. https://doi.org/10.1111/amet.12259

Hook, Sidney (1955): The Hero in History. Boston: Beacon Press. 
Hufbauer, Benjamin (2016): „How Trump's Favorite Movie Explains Him”. POLITICO Magazine. https://www.politico.com/magazine/story/2016/06/donald-trump-2016-citizenkane-213943 (2018. február 6.).

Huysmans, Jef (2000): „The European Union and the Securitization of Migration”. JCMS: Journal of Common Market Studies 38(5): 751-77. https://doi.org/10.1111/1468$\underline{5965.00263}$

Illés, Gábor, András Körösényi, és Rudolf Metz (2018): „Broadening the Limits of Reconstructive Leadership: Constructivist Elements of Viktor Orbán's Regime-Building Politics". The British Journal of Politics and International Relations (online first). https://doi.org/10.1177/1369148118775043

Infratest dimap (2015a): ARD-DeutschlandTREND: Januar 2015. Ifratest dimap, DeutschlandTrend im ARD-Morgenmagazin. https://www.tagesschau.de/inland/deutschlandtrend-243.pdf (2018. május 22.).

(2015b): ARD-DeutschlandTREND: November 2015. Ifratest dimap, DeutschlandTrend im ARD-Morgenmagazin._https://www.tagesschau.de/inland/deutschlandtrend-435.pdf (2018. május 22.).

(2015c): ARD-DeutschlandTREND: September 2015. Ifratest dimap, DeutschlandTrend im ARD-Morgenmagazin. https://www.tagesschau.de/inland/deutschlandtrend-399.pdf (2018. május 22.).

(2015d): Merkel macht etwas Boden gut. Ifratest dimap, DeutschlandTrend im ARDMorgenmagazin._https://www.tagesschau.de/inland/deutschlandtrend-461.html (2018. május 22.).

(2016a): ARD-DeutschlandTREND: April 2016. Ifratest dimap, DeutschlandTrend im ARD-Morgenmagazin.

(2018. május 22.).

https://www.tagesschau.de/inland/deutschlandtrend-529.pdf

(2016b): ARD-DeutschlandTREND: Februar 2016. Ifratest dimap, DeutschlandTrend im ARD-Morgenmagazin. https://www.tagesschau.de/inland/deutschlandtrend-479.pdf (2018. május 22.).

(2016c): ARD-DeutschlandTREND: Januar 2016. Ifratest dimap, DeutschlandTrend im ARD-Morgenmagazin. $\quad$ https://www.tagesschau.de/inland/deutschlandtrend-469.pdf (2018. május 22.).

(2016d): Skepsis in der Flüchtlingsfrage wächst. Ifratest dimap, DeutschlandTrend im ARD-Morgenmagazin. https://www.tagesschau.de/inland/deutschlandtrend-471.html (2018. május 22.).

James, William (1907): „Pluralism, Pragmatism, and Instrumental Truth”. In Pragmatism, a New Name for Some Old Ways of Thinking: Popular Lectures on Philosophy, New York: Longmans, Green, 52-61.

Janky, Béla (2017): „Framing, Priming or Pretreament? Effects of News Reports on Attitudes toward Asylum Policy during the European Refugee Crisis". MTA TK Working Paper. http://szociologia.tk.mta.hu/uploads/files/2017/jf53labeling.pdf (2018. május 8.).

Jeffery, David, Tim Heppell, Richard Hayton, és Andrew Crines (2017): „The Conservative Party Leadership Election of 2016: An Analysis of the Voting Motivations of Conservative Parliamentarians". Parliamentary Affairs. 71(2): 263-282. https://doi.org/10.1093/pa/gsx027

Jennings, Will, és Gerry Stoker (2017): „Tilting Towards the Cosmopolitan Axis? Political Change in England and the 2017 General Election". The Political Quarterly 88(3): 35969. https://doi.org/10.1111/1467-923X.12403

Jones, Bryan D. (1989): „Causation, Constraint and Political Leadership”. In Leadership and Politics. New Perspectives in Political Science, Bryan D. Jones (szerk.) Lawrence, KS: University Press of Kansas, 3-14.

Juhász, Attila, és Csaba Molnár. (2016): „Magyarország sajátos helyzete az európai menekültválságban”. In Társadalmi riport 2016., Kolosi Tamás és Tóth István György (szerk.) Budapest: Tárki, 262-285. 
Juhász, József, és Ferenc Pusztai (2003): Magyar értelmező kéziszótár. Budapest: Akadémiai Kiadó.

Juncker, Jean-Claude (2015): „2015. évi értékelő beszéd az Unió helyzetéről. Az őszinteség, az egység és a szolidaritás ideje." Előadás Strasbourg. http://europa.eu/rapid/pressrelease_SPEECH-15-5614_hu.htm (2018. május 8.).

(2016): „Az Unió helyzete 2016. [Évértékelő beszéd].” Előadás Strasbourg. https://ec.europa.eu/commission/state-union-2016_hu (2018. május 8.).

Kalyvas, Andreas (2008): Democracy and the politics of the extraordinary: Max Weber, Carl Schmitt, and Hannah Arendt. Cambridge, England; New York: Cambridge University Press.

Kane, John (2001): The politics of moral capital. Cambridge ; New York: Cambridge University Press.

Kane, John, és Haig Patapan (2012): The democratic leader: how democracy defines, empowers, and limits its leaders. Oxford: Oxford University Press.

- (szerk.) (2014): Good democratic leadership: on prudence and judgment in modern democracies. First Edition. Oxford, United Kingdom; New York, NY: Oxford University Press.

Kane, John, Haig Patapan, és Paul 't Hart (szerk.) (2009): Dispersed democratic leadership: origins, dynamics, and implications. Oxford; New York: Oxford University Press.

Katz, Richard S., és Peter Mair (1995): „Changing Models of Party Organization and Party Democracy The Emergence of the Cartel Party". Party Politics 1(1): 5-28.

Keen, Richard, és Keen Jackson (2018): Membership of UK Political Parties. House of Commons Library.

Kellerman, Barbara (1984): „Leadership as a political act”. In Leadership: Multidisciplinary perspectives, Barbara Kellerman (szerk.) Englewood Cliffs, NJ: Prentice-Hall, 63-89).

(2004): Bad leadership: what it is, how it happens, why it matters. Boston: Harvard Business School Press.

(2008): Followership: how followers are creating change and changing leaders. Boston, Mass: Harvard Business School Press.

(2012): The end of leadership. 1st ed. New York: Harper Business, An Imprint of HarperCollinsPublishers.

Keohane, Nannerl O. (2010): Thinking about leadership. Princeton, N.J: Princeton University Press.

- (2015): „Dahl's concept of leadership: notes towards a theory of leadership in a democracy". Journal of Political Power 8(2): 229-47. https://doi.org/10.1080/2158379X.2015.1054580

(2016): „Leadership, Equality \& Democracy”. Daedalus 145(3): 8-20. https://doi.org/10.1162/DAED_a_00393

Khanin, Dmitry (2007): „Contrasting Burns and Bass: Does the Transactional-Transformational Paradigm Live up to Burns' Philosophy of Transforming Leadership?" Journal of Leadership Studies 1(3): 7-25. https://doi.org/10.1002/j1s.20022

Kisistók, Levente (2014): „16 százalékot esett Orbán népszerüsége egy hónap alatt - Medián”. közvéleménykutatók.hu. $\quad$ https://kozvelemenykutatok.hu/16-szazalekot-esett-orbannepszerusege-egy-honap-alatt-median/ (2018. május 22.).

Kiss, Balázs (2016): „Orbán, Vona, Gyurcsány. Politikai vezetők integrációs tevékenysége a migrációs válság idején." Politikatudományi Szemle 25(3): 10-32.

Kitzinger, Dávid (2000): „A morális pánik elmélete”. Replika (40): 23-48.

Klenke, Karin (2008): Qualitative Research in the Study of Leadership. 1. ed. Bingley: Emerald.

Komives, Susan R., és John P. Dugan (2010): „Contemporary leadership theories”. In Political and civic leadership: A reference handbook, Richard A. Couto (szerk.) Thousand Oaks, Calif: SAGE Publications, 111-120. 
kormany.hu (2015): „Nemzeti konzultáció a bevándorlásról és a terrorizmusról." http://www.kormany.hu/download/4/d3/c0000/Bev\%20konzult\%C3\%A1ci\%C3\%B3\%20 eredm\%C3\%A9nyei.pdf (2018. május 9.).

Kort, E. D. (2008): „What, after all, is leadership? 'Leadership' and plural action”. The Leadership Quarterly 19(4): 409-25. https://doi.org/10.1016/j.leaqua.2008.05.003

Körösényi, András (2005): Vezér és demokrácia: politikaelméleti tanulmányok. Budapest: L'Harmattan.

(2006): „Elszámoltatható-e a kormány? Képviselet, demokrácia és a 2006. évi választások". In Parlamenti választás, 2006: elemzések és adatok, Karácsony Gergely (szerk.) Budapest: Demokrácia Kutatatások Magyar Központja Közhasznú Alapítvány, 252-291.

(2007): „A demokratikus elitizmus konszenzusán túl”. Politikatudományi Szemle 16(4): 7-28.

(2009a): „Escher lépcsőin: vezetés, manipuláció és demokrácia”. Századvég 15(54): 3 25.

(2009b): „Lehangoló tudomány, vagy a politika művészete? Vezetés, manipuláció és demokrácia". Politikatudományi Szemle 18(3): 33-56.

(2009c): „Political Leadership: Classical vs. Leader Democracy”. In Political Leadership in Liberal and Democratic Theory, András Körösényi, Joseph Femia, és Gabriella Slomp (szerk.) Exeter: Imprint Academic, 79-100.

(2010): „Stuck in Escher's staircase: Leadership, manipulation and democracy”. Österreichische Zeitschrift für Politikwissenschaft (ÖZP) 39(3): 289-302. https://doi.org/10.15203/ozp.596.vol39iss3

(2012): „Monopolista verseny, árverés és felhatalmazás”. Politikatudományi Szemle 21(2): 7-23.

(2016): „Joseph Schumpeter: egy realista demokráciaelmélet”. In A hatalom ködében: bevezetés a realista politikaelméletbe, Gyulai Attila és Szűcs Zoltán Gábor (szerk.) Budapest: MTA Társadalomtudományi Kutatóközpont Politikatudományi Intézet: L'Harmattan Kiadó, 202-16.

(2017): „Weber és az Orbán-rezsim: plebiszciter vezérdemokrácia Magyarországon”. Politikatudományi Szemle 26(4): 7-28.

Körösényi, András, Hajdú András, és Ondré Péter (2015): „Politikai vezetők: kormányfői karrier és teljesítmény”. In A magyar politikai rendszer - negyedszázad után, Körösényi András (szerk.) Budapest: MTA TK - Osiris.

Körösényi, András, Gábor Illés, és Rudolf Metz (2016): „Contingency and Political Action: The Role of Leadership in Endogenously Created Crises”. Politics and Governance 4(2): 91103. http://dx.doi.org/10.17645/pag.v4i2.530

Körösényi, András, és Veronika Patkós (2017): „Variations for Inspirational Leadership: The Incumbency of Berlusconi and Orbán". Parliamentary Affairs 70(3): 611-32. https://doi.org/10.1093/pa/gsx004

Krouse, Richard W. (1982): „Polyarchy \& Participation: The Changing Democratic Theory of Robert Dahl". Polity 14(3): 441-63. https://doi.org/10.2307/3234535

Kuyper, Jonathan (2012): „Deliberative Democracy and the Neglected Dimension of Leadership". Journal of Public Deliberation 8(1).

Lipman-Blumen, Jean (2005) „Toxic Leadership: When Grand Illusions Masquerade as Noble Visions". Leader to Leader 2005(36): 29-36. https://doi.org/10.1002/lt1.125

Little, Graham (1988): Strong leadership: Thatcher, Reagan, and an eminent person. Melbourne; New York: Oxford University Press.

Lord, Carnes (2003): The modern prince: what leaders need to know now. New Haven: Yale University Press.

Machiavelli, Niccolò (2015): A fejedelem. Budapest: Helikon Kiadó. 
Mándi, Tibor (2015): „Politikai gondolkodás”. In A magyar politikai rendszer - negyedszazad utan, Körösényi András (szerk.) Budapest: Osiris - MTA, 13-34.

Mannheim, Karl (1996): Ideólogia és utópia. Budapest: Atlantisz.

Mansbridge, Jane (2006): „Conflict and Self-Interest in Deliberation”. In Deliberative democracy and its discontents, Applied legal philosophy, Samantha Besson és José Luis Martí (szerk.) Aldershot, Hants, England; Burlington, VT: Ashgate, 107-132.

Mansbridge, Jane és mtsai. (2010): „The Place of Self-Interest and the Role of Power in Deliberative Democracy". Journal of Political Philosophy 18(1): 64-100. https://doi.org/10.1111/j.1467-9760.2009.00344.x

Mansfield, Harvey Claflin (1989): Taming the prince: the ambivalence of modern executive power. New York: London: Free Press ; Collier Macmillan.

May, Theresa. (2002): „Conference speech”. https://www.theguardian.com/politics/2002/oct/07/conservatives2002.conservatives1 (2018. március 12.).

(2016a): „Britain, the great meritocracy”. https://www.gov.uk/government/speeches/britain-the-great-meritocracy-prime-ministersspeech (2018. március 26.).

(2016b): „G20 Summit, China: Prime Minister's press conference”. https://www.gov.uk/government/speeches/g20-summit-china-prime-ministers-pressconference-5-september-2016 (2018. március 26.).

(2016c): „PM and Slovakian Prime Minister Fico statements in Bratislava”. https://www.gov.uk/government/speeches/pm-and-slovakian-prime-minister-ficostatements-in-bratislava-28-july-2016 (2018. március 26.).

(2016d): „PM speech to the Lord Mayor's Banquet”. https://www.gov.uk/government/speeches/pm-speech-to-the-lord-mayors-banquet-14november-2016 (2018. március 26.).

(2016e): „Speech at Conservative Party Conference”. http://www.ukpol.co.uk/theresamay-2016-speech-at-conservative-party-conference/ (2018. március 26.).

(2017a): „Brexit Speech”. https://www.telegraph.co.uk/politics/2017/01/17/theresamays-brexit-speech-full/ (2018. március 26.).

(2017b): „Davos 2017”. https://www.gov.uk/government/speeches/davos-2017-primeministers-speech-to-the-world-economic-forum (2018. március 26.).

(2017c): „General election 2017”. https://www.gov.uk/government/speeches/pmstatement-general-election-2017 (2018. március 26.).

(2017d): „General Election Announcement”. http://www.ukpol.co.uk/theresa-may2017-general-election-announcement/ (2018. március 26.).

- (2017e): „Questions to the Prime Minister (He can lead a protest; I am leading a country)". http://www.bbc.com/news/av/uk-politics-38830543/may-he-leads-a-protest-ilead-country (2018. március 26.).

(2017f): „Speech in Bolton”. http://www.ukpol.co.uk/theresa-may-2017-speech-inbolton/ (2018. március 26.).

- (2017g): „Strong leadership speech”. https://blogs.spectator.co.uk/2017/06/theresamays-strong-leadership-speech-full-transrcipt/ (2018. március 26.).

(2017h): „The government's negotiating objectives for exiting the EU". https://www.gov.uk/government/speeches/the-governments-negotiating-objectives-forexiting-the-eu-pm-speech (2018. március 26.).

McFarland, Andrew S. (1969): Power and Leadership in Pluralist Systems. Stanford, Calif: Stanford University Press.

McLean, Iain (2002): „William H. Riker and the Invention of Heresthetic(s)”. British Journal of Political Science 32(3): 535-58. https://doi.org/10.1017/S0007123402000224

Medearis, John (2005): „Social Movements and Deliberative Democratic Theory”. British Journal of Political Science 35(1): 53-75. https://doi.org/10.1017/S0007123405000037 
Medián (2015a): Jobb félni? Medián-felmérés a menekültválságról. Medián. http://www.webaudit.hu/object.c38fa2c9-5bc2-40c9-ae38-bab515a5f172.ivy (2017. február 19.).

(2015b): Menekültválság: Fidesz fel, Jobbik le. Medián. http://www.median.hu/object.7ebb5252-0697-4a1d-8494-6019f109655b.ivy (2018. május 22.).

Medvic, Stephen K. (2013): In defense of politicians: the expectations trap and its threat to democracy. New York: Routledge.

Meindl, James R., Sanford B. Ehrlich, és Janet M. Dukerich. (1985): „The Romance of Leadership". Administrative Science Quarterly 30(1): 78-102.

Meiritz, Annett (2015): „How Germany became Europe's moral leader on the refugee crisis”. Vox. https://www.vox.com/2015/9/11/9307209/q-a-germanys-leadership-role-in-theeuropean-migrant-crisis (2018. május 23.).

Mellon, Jonathan és mtsai. (2018): „Brexit or Corbyn? Campaign and Inter-Election Vote Switching in the 2017 UK General Election". Parliamentary Affairs na(na): 1-19. http://dx.doi.org/10.2139/ssrn.3073203

Merkel, Angela (2015a): „Ganz Europa ist gefordert”. https://www.bundeskanzlerin.de/Content/DE/Interview/2015/09/2015-09-05-merkelinterview.html (2018. szeptember 10.).

(2015b): „Jeden Menschen als Menschen behandeln”. https://www.bundeskanzlerin.de/Content/DE/Interview/2015/10/2015-10-04-merkeldlf.html (2018. május 9.).

(2015c): „Meine Aufgabe ist es, Lösungen $\mathrm{zu}$ finden”. https://www.bundeskanzlerin.de/Content/DE/Interview/2015/10/2015-10-12-merkelbild.html (2018. május 9.).

(2015d):

„Neujahrsansprache

$2015 "$

https://www.bundesregierung.de/Content/DE/Bulletin/2010-2015/2015/01/01-1-bkneujahr.html (2018. május 9.).

(2015e): „Pressekonferenz von Bundeskanzlerin Merkel und dem österreichischen Bundeskanzler

Faymann".

https://www.bundeskanzlerin.de/Content/DE/Mitschrift/Pressekonferenzen/2015/09/2015 -09-15-merkel-faymann.html (2018. május 9.).

(2015f): „Pressekonferenz von Bundeskanzlerin Merkel und dem ungarischen Ministerpräsidenten

Orbán". https://www.bundeskanzlerin.de/Content/DE/Mitschrift/Pressekonferenzen/2015/02/2015 -02-02-merkel-orban.html (2018. május 9.).

(2015g): „Pressekonferenz von Bundeskanzlerin Merkel und der Schweizer Bundespräsidentin Sommaruga". https://www.bundeskanzlerin.de/Content/DE/Mitschrift/Pressekonferenzen/2015/09/2015 -09-03-pk-bern.html (2018. szeptember 10.).

(2015h): „Pressekonferenz von Bundeskanzlerin Merkel zum informellen Treffen der Staats- und Regierungschefs der Europäischen Union". https://www.bundesregierung.de/Content/DE/Mitschrift/Pressekonferenzen/2015/09/2015 -09-24-merkel-sonder-er.html (2018. május 9.).

(2015i): „Pressestatement von Bundeskanzlerin Merkel anlässlich der Terroranschläge in

Paris".

https://www.bundeskanzlerin.de/Content/DE/Mitschrift/Pressekonferenzen/2015/11/2015 -11-14-statement-merkel-paris.html (2018. május 9.).

(2015j): „Pressestatement von Bundeskanzlerin Merkel zum Besuch der Flüchtlingsunterkunft in Heidenau". https://www.bundeskanzlerin.de/Content/DE/Mitschrift/Pressekonferenzen/2015/08/2015 -08-26-merkel-heidenau.html (2018. május 9.). 
(2015k): „Pressestatements von Bundeskanzlerin Merkel und dem französischen Staatspräsidenten Hollande vor ihrem Gespräch". https://www.bundeskanzlerin.de/Content/DE/Mitschrift/Pressekonferenzen/2015/08/2015 -08-24-pressestatements-merkel-hollande.html (2018. május 9.).

- (20151): „Rede von Bundeskanzlerin Dr. Angela Merkel beim Festakt zum 60. Jubiläum der Deutschen Handelskammer". https://www.bundesregierung.de/Content/DE/Bulletin/2010-2015/2015/08/103-3-bkoesterreich.html (2018. május 9.).

(2015m): „Rede von Bundeskanzlerin Merkel am 7. Oktober 2015 vor dem Europäischen Parlament”. https://www.bundeskanzlerin.de/Content/DE/Rede/2015/10/2015-10-07-rede-bkin-euparlament.html (2018. május 9.).

(2015n): „Rede von Bundeskanzlerin Merkel anlässlich des 60. Jahrestages der Abstimmung über das Saarstatut". https://www.bundeskanzlerin.de/Content/DE/Rede/2015/10/2015-10-23-rede-festaktsaarbruecken.html (2018. május 9.).

- (2015o): „Rede von Bundeskanzlerin Merkel im Deutschen Bundestag (2015.09.09.)”. https://www.bundeskanzlerin.de/Content/DE/Rede/2015/09/2015-09-10-rede-deutscherbundestag.html (2018. szeptember 10.).

(2015p): „Rede von Bundeskanzlerin Merkel zum Einzelplan 04”. https://www.bundeskanzlerin.de/Content/DE/Rede/2015/11/2015-11-26-rede-merkelhaushalt.html (2018. május 9.).

(2015q): „Regierungserklärung von Bundeskanzlerin Merkel (2015.01.15.)”. https://www.bundesregierung.de/Content/DE/Regierungserklaerung/2015/2015-01-15regierungserklaerung.html (2018. május 9.).

(2015r): „Regierungserklärung von Bundeskanzlerin Merkel (2015.12.16.)”. https://www.bundeskanzlerin.de/Content/DE/Regierungserklaerung/2015/2015-12-17regierungserklaerung.html (2018. május 9.).

(2015s): „Sommerpressekonferenz von Bundeskanzlerin Merkel”. https://www.bundesregierung.de/Content/DE/Mitschrift/Pressekonferenzen/2015/08/2015 -08-31-pk-merkel.html (2018. május 9.).

(2015t): „Wir brauchen eine faire Lastenverteilung”. https://www.bundesregierung.de/Content/DE/Interview/2015/09/2015-09-11-merkelrp.html (2018. május 9.).

(2015u): „Wir wissen $\mathrm{zu}$ wenig über den Islam”. https://www.bundeskanzlerin.de/Content/DE/Interview/2015/01/2015-01-16-merkelfaz.html (2018. szeptember 10.).

(2016a): „Rede von Bundeskanzlerin Merkel beim 10. Deutschen Stiftungstag”. https://www.bundesregierung.de/Content/DE/Rede/2016/05/2016-05-12-bkinstiftungstag.html (2018. május 9.).

(2016b): „Rede von Bundeskanzlerin Merkel im Deutschen Bundestag (2016.09.07.)”. https://www.bundeskanzlerin.de/Content/DE/Rede/2016/09/2016-09-07-merkelbundestag.html (2018. május 9.).

- (2016c): „Rede von Bundeskanzlerin Merkel im Rahmen des Jahresempfangs des Deutschen Caritasverbands e.V." https://www.bundeskanzlerin.de/Content/DE/Rede/2016/04/2016-04-15-bkin-caritas.html (2018. május 9.).

(2016d): „Regierungserklärung von Bundeskanzlerin Merkel (2016.06.28.)”. https://www.bundeskanzlerin.de/Content/DE/Regierungserklaerung/2016/2016-06-28regierungserklaerung.html (2018. május 9.).

(2016e): „Vor allem ein Satz des Anpackens”. https://www.bundeskanzlerin.de/Content/DE/Interview/2016/08/2016-08-31-merkelsz.html (2018. május 9.). 
Merkel, Wolfgang (2014): „Is There a Crisis of Democracy?” Democratic Theory 1(2). https://doi.org/10.3167/dt.2014.010202

Messing, Vera, és Gábor Bernáth (2015): „Bedarálva: A menekültekkel kapcsolatos kormányzati kampány és a tőle független megszólalás terepei”. Médiakutató: médiaelméleti folyóirat 16(4): 7-17.

(2017): „Biztonsági fenyegetés vagy humanitárius katasztrófa? A politikai jelentésképzés és beszivárgása médiába”. Médiakutató: médiaelméleti folyóirat 18(2): 3353.

Metz, Rudolf (2014): „A Vezérek »Régi-Új« Eszköze. A Politikai Mozgalmak Funkciója a Demokráciában". Politikatudományi Szemle (23): 105-30.

(2017a): „A kis-nagy ember: G.W. Bush és a 9/11-es terrortámadás”. In Viharban kormányozni: Politikai vezetök válsághelyzetekben, Körösényi András (szerk.) Budapest: MTA TK PTI, 218-239.

(2017b): „A politikai vezetés három arca: A vezetés értelmezési lehetőségei a demokráciában”. Századvég 85(3): 69-90.

- (2017c): „Határok nélkül?: Orbán Viktor és a migrációs válság”. In Viharban kormányozni: Politikai vezetők válsághelyzetekben, Körösényi András (szerk.) Budapest: MTA TK PTI, 240-264.

Middelhoff, Jurriaan, Petronella Schijvenaars, és Christ De Landtsheer (2016): „Political Personality and Complex Decision-Making. Thy Psychological Profile and Leadership Style of Angela Merkel, the World's Most Powerful Woman". In Complex Political Decision-Making: Leadership, Legitimacy and Communication, Peter Bursens, Christ'1 De Landtsheer, Luc Braeckmans, és Barbara Segaert (szerk.) Taylor \& Francis, 122-143.

Mommsen, Wolfgang J. (1990): Max Weber and German Politics, 1890-1920. Chicago: University of Chicago Press.

Morriss, Peter (2012): „A response to Pamela Pansardi”. Journal of Political Power 5(1): 9199. https://doi.org/10.1080/2158379X.2012.660027

Mushaben, Joyce Marie (2017a): „Angela Merkel's Leadership in the Refugee Crisis”. Current History. A Journal of Contemporary Wolrd Affairs 116(788): 95-100.

(2017b): „Wir Schaffen Das! Angela Merkel and the European Refugee Crisis”. German Politics 26(4): 516-33. https://doi.org/10.1080/09644008.2017.1366988

Nemzeti Választási Iroda (2014): Országgyülési képviselők választása 2014. április 6. eredmények. Nemzeti Választási Iroda. http://www.valasztas.hu/dyn/pv14/szavossz/hu/eredind.html (2018. május 22.).

(2016): Népszavazás 2016. október 2. - összesitett eredmények. Nemzeti Választási Iroda. http://www.valasztas.hu/osszesitett-eredmenyek-nepszavazas-2016.10.02. (2018. május 22.).

Nézőpont Intézet (2015): „Nemzeti egység a kormány mögött bevándorlás-ügyben”. http://nezopontintezet.hu/analysis/nemzeti-egyseg-kormany-mogott-bevandorlas-ugyben/ (2016. november 12.).

Norris, Pippa (2017): „Why the Younger Generation of Corbynistas?” In UK Election Analysis 2017: Media, Voters and the Campaign, Einar Thorsen, Daniel Jackson, és Darren G Lilleker (szerk.) Poole, England: The Centre for the Study of Journalism, Culture and Community Bournemouth University, 22-23.

Northouse, Peter Guy (2013): Leadership: theory and practice. 6th ed. Thousand Oaks: SAGE.

Nye, Joseph S. (2008): The Powers to Lead. Paperback ed. New York;Oxford: Oxford University Press.

Olson, Mancur (1971): The Logic of Collective Action: Public Goods and the Theory of Groups. Cambridge, Mass.: Harvard Univ. Press.

Orbán, Viktor (2015a): „A Weltwoche svájci hetilap interjúja Orbán Viktorral”. http://www.kormany.hu/hu/a-miniszterelnok/beszedek-publikaciok-interjuk/a-weltwochesvajci-hetilap-interjuja-orban-viktorral (2018. május 9.). 
(2015b): „Orbán Viktor a Kossuth Rádió »180 perc« címü műsorában (2015.12.04.)”. http://www.kormany.hu/hu/a-miniszterelnok/beszedek-publikaciok-interjuk/orban-viktora-kossuth-radio-180-perc-cimu-musoraban20151204 (2018. május 9.).

(2015c): „Orbán Viktor beszéde a Fidesz - Magyar Polgári Szövetség XXVI. kongresszusán".

http://2010-

2015.miniszterelnok.hu/beszed/orban_viktor_beszede_a_fidesz_magyar_polgari_szovets eg_xxvi._kongresszusan (2018. május 9.).

(2015d): „Orbán Viktor beszéde a XIV. kötcsei polgári pikniken”. http://www.kormany.hu/hu/a-miniszterelnok/beszedek-publikaciok-interjuk/orban-viktorbeszede-a-xiv-kotcsei-polgari-pikniken (2018. május 9.).

(2015e): „Orbán Viktor felszólalása az Európai Parlamentben”. http://www.kormany.hu/hu/a-miniszterelnok/beszedek-publikaciok-interjuk/orban-viktorfelszolalasa-az-europai-parlamentben (2018. május 9.).

(2015f): „Orbán Viktor interjúja a BILD Zeitungnak”. http://www.kormany.hu/hu/aminiszterelnok/beszedek-publikaciok-interjuk/orban-viktor-interjuja-a-bild-zeitungnak (2018. május 9.).

(2015g): „Orbán Viktor interjúja a Magyar Időknek”. http://www.kormany.hu/hu/aminiszterelnok/beszedek-publikaciok-interjuk/orban-viktor-interjuja-a-magyaridoknek20151224 (2018. május 9.).

(2015h): „Orbán Viktor interjúja a tv2 »Tények - Este« címü müsorában”. http://www.kormany.hu/hu/a-miniszterelnok/beszedek-publikaciok-interjuk/orban-viktorinterjuja-a-tv2-tenyek-este-cimu-musoraban (2018. május 9.).

(2015i): „Orbán Viktor napirend előtti felszólalása”. http://www.kormany.hu/hu/aminiszterelnok/beszedek-publikaciok-interjuk/orban-viktor-napirend-elottifelszolalasa20151116 (2018. május 9.).

(2015j): „Orbán Viktor reagálása az európai parlamenti képviselők kérdéseire”. http://2010-

2015.miniszterelnok.hu/beszed/orban viktor reagalasa az europai parlamenti kepvisel ok_kerdeseire (2018. május 9.).

(2016a): „Exkluzív interjú Orbán Viktor miniszterelnökkel”. https://www.youtube.com/watch?v=qrLCaa5BErQ (2018. május 9.).

(2016b): „Minden harminc évben egyszer a fösodorba kerülünk”. Magyar Idök. https://magyaridok.hu/velemeny/minden-harminc-evben-egyszer-fosodorba-kerulunk1052359/ (2018. május 9.).

(2016c): „Orbán Viktor a Kossuth Rádió »180 perc« címü müsorában (2016.01.22.)”. http://www.kormany.hu/hu/a-miniszterelnok/beszedek-publikaciok-interjuk/orban-viktora-kossuth-radio-180-perc-cimu-musoraban20160123 (2018. május 9.).

- (2016d): „Orbán Viktor a Kossuth Rádió »180 perc« című müsorában (2016.02.05.)”. http://www.kormany.hu/hu/a-miniszterelnok/beszedek-publikaciok-interjuk/orban-viktora-kossuth-radio-180-perc-cimu-musoraban20160122 (2018. május 9.).

- (2016e): „Orbán Viktor a Kossuth Rádió »180 perc« című müsorában (2016.03.04.)”. http://www.kormany.hu/hu/a-miniszterelnok/beszedek-publikaciok-interjuk/orban-viktora-kossuth-radio-180-perc-cimu-musoraban20160304 (2018. május 9.).

(2016f): „Orbán Viktor a Kossuth Rádió »180 perc« címü müsorában (2016.05.20.)”. http://www.kormany.hu/hu/a-miniszterelnok/beszedek-publikaciok-interjuk/orban-viktorinterjuja-a-kossuth-radio-180-perc-cimu-musoraban20160520 (2018. május 9.).

(2016g): „Orbán Viktor a Kossuth Rádió »180 perc« címü müsorában (2016.06.24.)”. http://www.kormany.hu/hu/a-miniszterelnok/beszedek-publikaciok-interjuk/orban-viktorinterjuja-a-kossuth-radio-180-perc-cimu-musoraban20160624 (2018. május 9.).

- (2016h): „Orbán Viktor a Kossuth Rádió »180 perc« című műsorában (2016.08.26.)”. http://www.kormany.hu/hu/a-miniszterelnok/beszedek-publikaciok-interjuk/orban-viktorinterjuja-a-kossuth-radio-180-perc-cimu-musoraban20160826 (2018. május 9.). 
(2016i): „Orbán Viktor előadása a XXVII. Bálványosi Nyári Szabadegyetem és Diáktáborban". http://www.kormany.hu/hu/a-miniszterelnok/beszedek-publikaciokinterjuk/orban-viktor-eloadasa-a-xxvii-balvanyosi-nyari-szabadegyetem-es-diaktaborban (2018. május 9.).

(2016j): „Orbán Viktor évértékelő beszéde”. http://www.kormany.hu/hu/aminiszterelnok/beszedek-publikaciok-interjuk/orban-viktor-evertekelo-beszede $\quad$ (2018. május 9.).

(2016k): „Orbán Viktor interjúja a BILD című német napilapnak”. http://www.kormany.hu/hu/a-miniszterelnok/beszedek-publikaciok-interjuk/orban-viktorinterjuja-a-bild-cimu-nemet-napilapnak (2018. május 9.).

(20161): „Orbán Viktor ünnepi beszéde”. http://www.kormany.hu/hu/aminiszterelnok/beszedek-publikaciok-interjuk/orban-viktor-unnepi-beszede (2018. május 9.).

(2016m): „Te a béke ellen vagy?” http://www.kormany.hu/hu/aminiszterelnok/beszedek-publikaciok-interjuk/orban-viktor-cikke-a-frankfurterallgemeine-zeitungban (2018. május 9.).

Origo (2017): „Medián: Óriási fölényben a Fidesz, bedőlt a Jobbik”. http://www.origo.hu/itthon/20170208-fidesz-foleny-median-jobbik-osszezuhanasfelmeres.html (2018. május 22.).

Ospina, Sonja, és Georgia Jones Sorenson (2006): „A constructionist lens on leadership: charting new territory". In The quest for a general theory of leadership, New horizons in leadership studies, George R. Goethals és Georgia Jones Sorenson (szerk.) Cheltenham, UK ; Northampton, MA: Edward Elgar, 188-204.

Pace, Michelle (2007): „The Construction of EU Normative Power”. JCMS: Journal of Common Market Studies 45(5): 1041-64. https://doi.org/10.1111/j.14685965.2007.00759.x

Paige, Glenn D. (1977): The scientific study of political leadership. New York: Free Press.

Pakulski, Jan (2013): „Leadership Trends in Advanced Democracies”. Sociology Compass 7(3): 366-376. https://doi.org/10.1111/soc4.12035

Pakulski, Jan, és John Higley (2008): „Towards Leader Democracy?” In Public leadership perspectives and practices, ANZSOG series, Paul 't Hart és John Uhr (szerk.) Canberra A.C.T: ANU E Press, 45-56.

Pakulski, Jan, és András Körösényi (2012): Toward Leader Democracy. London: Anthem Press.

Palonen, Kari (1998): Das „Webersche Moment”: zur Kontingenz des Politischen. Opladen: Westdeutscher Verlag.

Pansardi, Pamela (2011a): „Power to and Power over” Keith M. Dowding (szerk.) Encyclopedia of power: 521-24.

(2011b): „Power with” Keith M. Dowding (szerk.) Encyclopedia of power: 527-28.

(2012a): „On abilities and power again: a reply to Peter Morriss”. Journal of Political Power 5(3): 493-97. https://doi.org/10.1080/2158379X.2012.735120

(2012b): „Power to and power over: two distinct concepts of power?” Journal of Political Power 5(1): 73-89. https://doi.org/10.1080/2158379X.2012.658278

Pateman, Carole (1970): Participation and Democratic Theory. Cambridge: Cambridge University Press.

Pearce, Craig L., és Jay Alden Conger (szerk.) (2003): Shared leadership: reframing the hows and whys of leadership. Thousand Oaks, Calif: Sage Publications.

Pearce, W. Bennett (1995): „A sailing guide for social constructionists.” In Social approaches to communication, W. Leeds-Hurwitz (szerk.) New York: Guilford, 88-113.

Peele, Gillian (2012): „The United Kingdom: prime ministerial leadership and the challenge of governance". In Poor leadership and bad governance: reassessing presidents and prime ministers in North America, Europe and Japan, New horizons in leadership studies, Ludger Helms (szerk.) Cheltenham; Northampton, Mass: Edward Elgar, 64-86. 
Perkins, Douglas D. (2010): „Empowerment”. In Political and civic leadership: a reference handbook, Richard A. Couto (szerk.) Thousand Oaks, Calif: SAGE Publications, 207-18.

Philp, Mark (2007): Political conduct. Cambridge, Mass: Harvard University Press.

Pocock, John G. A. (1975): The Machiavellian Moment: Florentine Political Thought and the Atlantic Republican Tradition. Princeton, NJ: Princeton Univ. Press.

Popescu, Alexandra (2016): „The EU »Costs« of The Refugee Crisis”. Europolity 10.(1): 105120.

Prosser, Christopher (2018): „The Strange Death of Multi-Party Britain: The UK General Election of 2017". West European Politics: 1226-36. https://doi.org/10.1080/01402382.2018.1424838

Przeworski, Adam (1998): „Deliberation and Ideological Domination”. In Deliberative democracy, Cambridge studies in the theory of democracy, Jon Elster (szerk.) Cambridge, U.K. ; New York: Cambridge University Press, 140-60.

- (1999): „Minimalist conception of democracy: A defence”. In Democracy's value, Contemporary political theory, Ian Shapiro és Casiano Hacker-Cordón (szerk.) Cambridge, U.K. ; New York: Cambridge University Press, 23-55.

Rácz, András (2015): „A Calculated Non-action Miscalculated: Hungary's Migration Crisis.” http://visegradrevue.eu/a-calculated-non-action-miscalculated-hungarys-migration-crisis/ (2018. május 9.).

Radu, Loredana (2016): „More or Less Europe? The European Leaders' Discourses on the Refugees Crisis". Romanian Journal of Communication and Public Relations 18(2): 21 37. https://doi.org/10.21018/rjcpr.2016.2.207

Raelin, Joseph A. (2011): „From Leadership-as-Practice to Leaderful Practice”. Leadership 7(2): 195-211. https://doi.org/10.1177/1742715010394808

- (2012): „Dialogue and Deliberation as Expressions of Democratic Leadership in Participatory Organizational Change". Journal of Organizational Change Management 25(1): 7-23. https://doi.org/10.1108/09534811211199574

Rawls, John (1993): Political liberalism. Expanded ed. New York: Columbia University Press. (1997): A Theory of Justice. 22. print. Cambridge, Mass. Harvard Univ. Press.

Rhodes, R. A. W., és Paul 't Hart (szerk.) (2014): The Oxford Handbook of Political Leadership. Oxford Handbooks in Politics \& International Relations.

Riker, William H. (1986): The art of political manipulation. New Haven: Yale University Press.

Rost, Joseph C. (1991): Leadership for the twenty-first century. New York: Praeger.

Rostbøll, Christian F. (2005): „Preferences and Paternalism on Freedom and Deliberative Democracy". Political Theory 33(3): 370-96. https://doi.org/10.1177/0090591704272351

Rothenberg, Albert (1971): „The Process of Janusian Thinking in Creativity”. Archives of General Psychiatry 24(3): 195-205. http://dx.doi.org/10.1001/archpsyc.1971.01750090001001

Ruscio, Kenneth Patrick (2008): The leadership dilemma in modern democracy. Cheltenham, UK ; Northampton, MA: Edward Elgar.

Schabert, Tilo (2013): A politika méltóságáról és jelentőségéről. Budapest: Századvég.

Schmitter, Philippe C., és Terry Lynn Karl (1991): „What democracy is... and is not”. Journal of Democrac 2(3): 75-88. https://doi.org/10.1353/jod.1991.0033

Schumpeter, Joseph A. (2006): Capitalism, Socialism and Democracy. New York; Florence: Routledge Taylor \& Francis Group.

Shapiro, Ian (2005): The Flight from Reality in the Human Sciences. Princeton, NJ: Princeton Univ. Press.

- (2014): „Judgement and Democratic Leadership”. In Good democratic leadership: on prudence and judgment in modern democracies, John Kane és Haig Patapan (szerk.) Oxford, United Kingdom; New York, NY: Oxford University Press, 128-139. 
Shaw, Eric (2016): „Fractured and unmanageable? Labour Party Management under Blair and under Corbyn". LSE British Politics and Policy Blog. http://blogs.lse.ac.uk/politicsandpolicy/labour-party-management-under-blair/ $\quad$ (2017. július 18.).

(2017): „Why Corbyn's leadership is being judged neither prematurely nor by the wrong standards". LSE British Politics and Policy Blog. http://blogs.lse.ac.uk/politicsandpolicy/jeremy-corbyn-leadership-not-what-labour-needs/ (2017. július 18.).

Sík, Endre (2017): „Rekordot döntött az idegenellenesség Magyarországon”. Népszava Online. http://nepszava.hu/cikk/1119911-rekordot-dontott-az-idegenellenesseg-magyarorszagon (2018. május 22.).

Skowronek, Stephen (1997): The politics presidents make: leadership from John Adams to Bill Clinton. Cambridge, Mass: The Belknap Press of Harvard University Press.

Sonnevend, Pál, András Jakab, és Lóránt Csink (2015): „The Constitution as an Instrument of Everyday Party Politics: The Basic Law of Hungary". In Constitutional crisis in the European constitutional area: theory, law and politics in Hungary and Romania, Armin von Bogdandy és Pál Sonnevend (szerk.) Oxford, United Kingdom; Portland, Oregon: Hart Publishing, 33-111.

Stefani, Lorraine (2017): „Inclusive, Authentic, Values-Based or Opportunistic - What Counts as Leadership Today? A Case Study of Angela, Donald, Francis and Helen.” In Breaking the Zero-Sum Game: Transforming Societies through Inclusive Leadership, Building leadership bridges, Aldo Boitano de Moras, Raúl Lagomarsino Dutra, és H. Eric Schockman (szerk.) Bingley, UK: Emerald Publishing Limited, 459-75.

Szalai, András, és Gabriella Gőbl (2016): „Securitizing Migration in Contemporary Hungary: From Discourse to Practice [Working Paper]". CEU Center for EU Enlargement Studies. https://pds.ceu.edu/events/2016-10-20/securitizing-migration-contemporary-hungarydiscourse-practice (2018. május 9.).

Századvég (2015a): „A magyarok többsége támogatja a magyar-szerb határra tervezett biztonsági határzárat". http://szazadveg.hu/foundation/kutatas/piac-es-kozvelemenykutatas/a-magyarok-tobbsege-tamogatja-a-magyar-szerb-hatarra-tervezett-biztonsagihatarzarat (2016. november 12.).

(2015b): „Szigorúbb bevándorláspolitikát! - A közvélemény 82 százaléka a kormány mellett”. http://szazadveg.hu/foundation/kutatas/piac-es-kozvelemeny-kutatas/szigorubbbevandorlaspolitikat-a-kozvelemeny-82-szazaleka-a-kormany-mellett (2016. november 12.).

Tárki (2016): Csúcsot döntött az idegenellenesség, és elfogyott az idegenbarátság. Tárki. http://www.tarki.hu/hu/news/2016/kitekint/20160404_idegen.html (2016. november 12.).

Teles, Filipe (2012): „Political leaders: the paradox of freedom and democracy”. Revista enfoques (Santiago) 10(16): 113-31.

(2015): „The Distinctiveness of Democratic Political Leadership”. Political Studies Review 13(1): 22-36. https://doi.org/10.1111/1478-9302.12029

The Economist (2015): „Illiberalism: Playing with fear”. The Economist. http://www.economist.com/news/leaders/21679792-america-and-europe-right-wingpopulist-politicians-are-march-threat (2016. november 12.).

Tocqueville, Alexis de (1862): Democracy in America. London: Longman, Green, Longman, and Roberts.

Tourish, Dennis (2013): The dark side of transformational leadership: a critical perspective. New York: Routledge.

Trauner, Florian (2016): „Asylum Policy: The EU's 'Crises' and the Looming Policy Regime Failure". Journal of European Integration 38(3): 311-25. https://doi.org/10.1080/07036337.2016.1140756 
Trauner, Florian, és Jocelyn Turton (2017): "Welcome culture” the emergence and transformation of a public debate on migration". OZP - Austrian Journal of Political Science 46(1): 33-42. https://doi.org/10.15203/ozp.1587.vol46iss1

Tucker, Robert C. (1968): „The Theory of Charismatic Leadership”. Daedalus 97(3): 731-56. (1995): Politics as leadership. Rev. ed. Columbia: University of Missouri Press.

Tullock, Gordon (1965): „Entry Barriers in Politics”. The American Economic Review 55(1/2): 458-66. https://doi.org/10.1023/A:1007816209593

Uhl-Bien, Mary, Ronald E. Riggio, Kevin B. Lowe, és Melissa K. Carsten (2014): „Followership theory: A review and research agenda”. The Leadership Quarterly 25(1): 83-104. https://doi.org/10.1016/j.leaqua.2013.11.007

Uhr, John (2005): Terms of trust: arguments over ethics in Australian government. Sydney: UNSW Press.

(2014): „Rhetorical and Performative Analysis”. In The Oxford Handbook of Political Leadership, R. A. W. Rhodes és Paul 't Hart (szerk.) Oxford Handbooks in Politics \& International Relations.

Vick, Karl, és Simon Shuster (2015): „Person of the Year: Chancellor of the Free World”. TIME magazine. http://time.com/time-person-of-the-year-2015-angela-merkel/?iid=coverrecirc (2018. május 5.).

Virdee, Satnam, és Brendan McGeever (2017): „Racism, Crisis, Brexit”. Ethnic and Racial Studies: 1-18. https://doi.org/10.1080/01419870.2017.1361544

Vollmer, Bastian, és Serhat Karakayali (2018): „The Volatility of the Discourse on Refugees in Germany". Journal of Immigrant \& Refugee Studies 16(1-2): 118-39. https://doi.org/10.1080/15562948.2017.1288284

Waller, Luke (2015): „Viktor Orbán: The Conservative Subversive”. Politico. http://www.politico.eu/list/politico-28/viktor-orban/ (2016. november 12.).

Weber, Eric Thomas (2010): „Democratic Political Leadership”. In Political and civic leadership: a reference handbook, Richard A. Couto (szerk.) Thousand Oaks, Calif: SAGE Publications.

Weber, Max (1987): Gazdaság és Társadalom. A megértö szociológia alapvonalai. 1. Szociológiai kategóriatan Budapest: Közgazdasági és Jogi Könyvkiadó.

(1989): A politika mint hivatás. Budapest: Mủvelődéskutató Intézet.

(2009): Politikai szociológia politikai közösségek; az uralom. Budapest: Helikon K.

Williams, Ben (2017): „Theresa May's Premiership: Continuity or Change?” Political Insight 8(1): 10-13. https://doi.org/10.1177/2041905817702730

Wohlgemuth, Michael (2000): „Political Entrepreneurship and Bidding for Political Monopoly”. Journal of Evolutionary Economics 10(3): 273-95. https://doi.org/10.1007/s001910050015

Worthy, Ben, és Mark Bennister (2017): „Theresa May: leaking leadership capital?” LSE British Politics and Policy Blog. http://blogs.lse.ac.uk/politicsandpolicy/theresa-mayleadership-capital/ (2017. július 18.).

Wren, J. Thomas (2007): Inventing Leadership: The Challenge of Democracy. Cheltenham, UK; Northampton, MA: Edward Elgar.

YouGov (2017a): Survey Results 2017.06.06. YouGov. https://d25d2506sfb94s.cloudfront.net/cumulus uploads/document/3120p3cwrq/ImoResul ts 170601 PartyLeaders W.pdf (2018. március 26.).

(2017b): Survey Results 2017.06.07. YouGov. https://d25d2506sfb94s.cloudfront.net/cumulus_uploads/document/5dejcmcp1e/TanyaRe sults_170529_issues_website.pdf (2018. március 26.).

(2017c): Survey Results 2017.06.13. YouGov. https://d25d2506sfb94s.cloudfront.net/cumulus_uploads/document/smo1w49ph1/Internal Results_170613_2017Election_Demographics_W.pdf (2018. március 26.). 
(2017d): YouGov / Sunday Times Survey Results 2017.04.19. YouGov. https://d25d2506sfb94s.cloudfront.net/cumulus_uploads/document/04xxn42p3e/TimesRe sults 170419 VI Trackers GE W.pdf (2018. március 26.).

Young, Iris Marion (2001): „Activist Challenges to Deliberative Democracy”. Political Theory 29(5): 670-90. https://doi.org/10.1177/0090591701029005004 (2010): Inclusion and Democracy. Repr. Oxford: Oxford Univ. Press.

Zeit Online (2015): „Unsere Möglichkeiten sind endlich”. Zeit Online. https://www.zeit.de/politik/deutschland/2015-09/joachim-gauck-rede-fluechtlingeaufnahme-begrenzt (2018. május 23.).

Zuba, Krzysztof (2016): „Power Holders: One versus Many. Leadership and Elite Theories”. $\begin{array}{lllll}\text { Journal of Political } & \text { Power }\end{array}$ https://doi.org/10.1080/2158379X.2016.1191221 


\section{A SZERZŐ TÉMÁBAN SZÜLETETT PUBLIKÁCIÓI}

\section{Tudományos könyvek, könyvrészletek}

Illés, Gábor, Körösényi András, és Metz Rudolf (2017): „Orbán Viktor mint rekonstruktív vezető". In Trendek a magyar politikában - 2 A Fidesz és a többiek: pártok, mozgalmak, politikák, Boda Zsolt és Szabó Andrea (szerk.) Budapest: Napvilág Kiadó, MTA Társadalomtudományi Kutatóközpont Politikatudományi Intézete.

Körösényi, András, Illés Gábor, és Metz Rudolf (2017): „A politikai vezetők szerepe válsághelyzetekben: fogalmi-elméleti keret és kutatási kérdések". In Viharban kormányozni: Politikai vezetők válsághelyzetekben, Körösényi András (szerk.) Budapest: MTA TK PTI, 9-48.

Körösényi, András, Illés Gábor, és Metz Rudolf (2017): "Összefoglalás És Következtetések." In Viharban Kormányozni: Politikai Vezetők Válsághelyzetekben, Körösényi András (szerk.) Budapest: MTA TK PTI, 266-285.

Metz, Rudolf (2017): „A kis-nagy ember: G.W. Bush és a 9/11-es terrortámadás”. In Viharban kormányozni: Politikai vezetök válsághelyzetekben, Körösényi András (szerk.) Budapest: MTA TK PTI, 218-239.

Metz, Rudolf (2017): „Határok nélkül?: Orbán Viktor és a migrációs válság”. In Viharban kormányozni: Politikai vezetők válsághelyzetekben, Körösényi András (szerk.) Budapest: MTA TK PTI, 240-264.

Metz, Rudolf (2017): „Katasztrófák: avagy hogyan lett a Katrina hurrikánból és a fukushimai atombalesetből politikai válság”. In Viharban kormányozni: Politikai vezetők válsághelyzetekben, Körösényi András (szerk.) Budapest: MTA TK PTI, 48-70.

\section{Referált szakmai folyóirat cikkek}

Körösényi, András, Illés Gábor, and Metz Rudolf (2017): "Kontingencia És Politikai Cselekvés: A Politikai Vezetők Szerepe Válsághelyzetekben.” Politikatudományi Szemle 26(1): 7-28.

Metz, Rudolf (2014): „A Vezérek »Régi-Új« Eszköze. A Politikai Mozgalmak Funkciója a Demokráciában". Politikatudományi Szemle 23(3): 105-30.

Metz, Rudolf (2017): „A politikai vezetés három arca: A vezetés értelmezési lehetőségei a demokráciában”. Századvég 85(3): 69-90.

\section{Referált szakmai folyóirat cikkek (Angol nyelvü publikációk)}

Illés, Gábor, András Körösényi, és Rudolf Metz (2018): „Broadening the Limits of Reconstructive Leadership: Constructivist Elements of Viktor Orbán's Regime-Building Politics". The British Journal of Politics and International Relations (online first). (2018. május 25.). https://doi.org/10.1177/1369148118775043

Körösényi, András, Gábor Illés, és Rudolf Metz (2016): „Contingency and Political Action: The Role of Leadership in Endogenously Created Crises". Politics and Governance 4(2): 91-103. http://dx.doi.org/10.17645/pag.v4i2.530

Metz, Rudolf (2015): „Movement Entrepreneurship of an Incumbent Party. The Story of the Hungarian Incumbent Party Fidesz and the Civil Cooperation Forum". Intersections. East European Journal of Society and Politics 1(3): 81-100. https://doi.org/10.17356/ieejsp.v1i3.41 